Universidade de São Paulo

Faculdade de Filosofia, Letras e Ciências Humanas

Departamento de História

Programa de Pós-graduação em História Social

Diego Amorim Grola

\title{
Coleções de História Natural no Museu Paulista, 1894-1916
}


Universidade de São Paulo

Faculdade de Filosofia, Letras e Ciências Humanas

Departamento de História

Programa de Pós-graduação em História Social

Diego Amorim Grola

\section{Coleções de História Natural no Museu Paulista, 1894-1916}

Dissertação apresentada ao Programa de Pós-graduação em História Social do Departamento de História da Faculdade de Filosofia, Letras e Ciências Humanas da Universidade de São Paulo, para obtenção do título de Mestre em História.

Orientadora: Profa. Dra. Heloisa Maria Silveira Barbuy 
Autorizo a reprodução e divulgação total ou parcial deste trabalho, por qualquer meio convencional ou eletrônico, para fins de estudo e pesquisa, desde que citada a fonte. 
Grola, Diego Amorim. Coleções de História Natural no Museu Paulista, 1894-1916. Dissertação apresentada à Faculdade de Filosofia, Letras e Ciências Humanas da Universidade de São Paulo para obtenção do título de Mestre em História.

Aprovado em:

Banca examinadora:

$\operatorname{Prof}(a) . \operatorname{Dr}(a)$. Instituição:

Julgamento: Assinatura:

$\operatorname{Prof}(a)$. Dr(a). Instituição:

Julgamento: Assinatura:

Prof(a). $\operatorname{Dr}(a)$. Instituição:

Julgamento: Assinatura: 


\section{Agradecimentos}

A origem deste trabalho está vinculada, por um lado, a algumas inquietações que remontam ao ano de 2009, quando - após o término da graduação em História - passei a trabalhar no Instituto Geológico, órgão vinculado à Secretaria de Estado do Meio Ambiente de São Paulo. Ali, meu interesse pré-existente pela questão da cultura material canalizou-se, a partir do contato com o dia-a-dia da instituição, para a questão das práticas científicas. Por outro lado, a escolha do objeto de estudo vincula-se aos interesses de pesquisa de minha orientadora, Professora Heloisa Barbuy, que já vinha desenvolvendo e orientando trabalhos sobre a história da instituição na qual atua como professora e curadora, o Museu Paulista. Após alguns diálogos, a Professora, entendendo que as intersecções entre coleções e ciências naturais poderiam ser um bom caminho de pesquisa, sugeriu que fosse tomado como objeto de estudo o Museu Paulista de Ihering.

Durante o percurso da pesquisa, foi fundamental a colaboração recebida de várias pessoas e instituições. À Professora Heloisa Barbuy, agradeço pela dedicação, paciência e generosidade, bem como pela perspicácia na leitura dos meus textos e na sugestão de encaminhamentos de pesquisa. Aos professores Ulpiano Toledo Bezerra de Meneses (FFLCH/USP) e Maria Margaret Lopes (UNICAMP), pelas críticas e sugestões criteriosas durante o exame de qualificação. Aos professores Alda Lúcia Heizer (Jardim Botânico/RJ), Dante Luiz Martins Teixeira (Museu Nacional) e Moema de Rezende Vergara (MAST), bem como ao historiador Maurício Cândido da Silva (FMVZ/USP), pelo apoio e pelas informações concedidas em diferentes fases da pesquisa.

Sem o apoio do Instituto Geológico, o trabalho não teria sido factível. Agradeço em particular ao Pesquisador Rogério Rodrigues Ribeiro, não só pelo voto de confiança para a execução deste projeto, como pela camaradagem e pelo exemplo de seriedade no serviço público.

Ao Museu Paulista, agradeço pela acolhida para realização da pesquisa, particularmente na Biblioteca, no Serviço de Documentação Textual e Iconografia e no Serviço de Objetos. Agradecimentos especiais aos funcionários Helton Celso 
Wanderley, Flávia Andrea Machado Urzua, Shirley Ribeiro da Silva, Tatiana Vasconcelos dos Santos e Thiago Malakowsky da Silva. Agradeço também às professoras Margarida Davina Andreatta, Miyoko Makino e Solange Ferraz de Lima pelo incentivo e pelas sugestões. Aos historiadores Adilson José de Almeida e Angela Maria Gianeze Ribeiro, pela colaboração e troca de informações. Às colegas Carina Marcondes Ferreira Pedro, Ludmila Érica Cambusano de Souza, Mariana Esteves Martins e Paula Carolina de Andrade Carvalho, pela ajuda com os enigmas do mestrado.

No Museu de Zoologia da USP, agradeço particularmente aos professores Carlos Roberto Ferreira Brandão, Hussam El Dine Zaher, Luís Fábio Silveira e Maria Isabel Landim pela disponibilização de documentos e informações sobre as coleções da instituição.

Cabe agradecer ainda às bibliotecas visitadas: além daquelas do Museu Paulista e do Museu de Zoologia, devo citar as das seguintes unidades da Universidade de São Paulo: Escola de Artes, Ciências e Humanidades; Faculdade de Arquitetura e Urbanismo; Faculdade de Educação; Faculdade de Filosofia, Letras e Ciências Humanas; Instituto de Biociências; Instituto de Estudos Brasileiros; Instituto de Geociências; e Museu de Arqueologia e Etnologia.

Ao Serviço Alemão de Intercâmbio Acadêmico (DAAD), agradeço pela oportunidade de passar seis semanas na Alemanha, adquirindo conhecimentos da língua e da cultura alemã.

Por fim, devo dizer que o trabalho teria sido muito mais árduo sem a convivência de amigos e familiares. Agradeço aos meus pais, Maura e Valentim, ao meu irmão Rodrigo e aos amigos de hoje e sempre: Alex, Diego Silva, Luiz, Nilton, Rafael e Ronaldo. Não poderia deixar de mencionar os colegas e amigos do Instituto Geológico: os velhos - Cristiane, Eduardo, Marisa, Maria Luiza, Rogério e Valéria e os novos - Barcellos, Cristina, Diamani, Fernando, João, Renato e Rodrigo. 


\section{Resumo}

Entre 1894 e 1916, período em que esteve sob a gestão do zoólogo Hermann von Ihering, o Museu Paulista conseguiu reunir coleções de dimensão considerável, que englobavam objetos pertinentes às diferentes disciplinas às quais a instituição se dedicava. Por meio dessas coleções, o Museu pôde produzir e veicular conhecimentos sobre a natureza e o homem sul-americano.

Embora intrínsecos à prática da História Natural, a reunião e uso de coleções podem ser problematizados e investigados com algum grau de profundidade, trazendo à tona dimensões insuspeitas da história dos museus e das ciências naturais. Sendo assim, objetiva-se, nesta dissertação, investigar aspectos de processos de aquisição e uso de coleções de História Natural praticados no Museu Paulista de Ihering. Pretende-se, dessa forma, contribuir para a compreensão do que foram a implantação e o desenvolvimento do primeiro museu público do estado de São Paulo. Mais do que isso, almeja-se entender o papel central reservado aos espécimes científicos na produção e veiculação de conhecimentos sobre a natureza sul-americana. Para tanto, examinaremos as principais etapas envolvidas na curadoria das coleções: a aquisição de objetos, sua mobilização para produção de conhecimento e sua exibição no âmbito das exposições públicas.

Palavras-chave: cultura material; coleções; espécimes científicos; Museu Paulista; Hermann von Ihering 


\section{Abstract}

Between 1894 and 1916, the Museu Paulista was under the management of the zoologist Hermann von Ihering. During this period, the museum gathered collections of considerable size, which encompassed objects concerning to different disciplines. Through these collections, the Museum was able to produce and communicate knowledge about the nature and the man of South America.

Gather and use collections are procedures intrinsic to the practice of Natural History. However, they may be deeply investigated, bringing out unsuspected dimensions of the history of museums and natural sciences. This dissertation aims to investigate the acquisition and use of collections of Natural History in the Museu Paulista of Ihering. We intend, therefore, to contribute to the understanding of the development of the first public museum in the state of São Paulo. More than that, we aim to understand the central role of scientific specimens in the production and communication of knowledge about the South American nature. To do so, we will examine the major steps involved in curating the collections: the acquisition of objects, its mobilization for the production of knowledge and its display in the public exhibitions.

Keywords: material culture; collections; scientific specimens; Museu Paulista; Hermann von Ihering 


\section{Sumário}

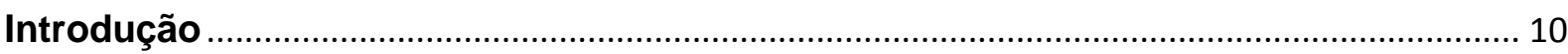

1. O comércio internacional de objetos de História Natural ............................................ 26

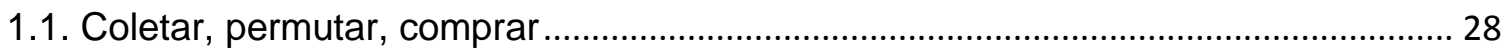

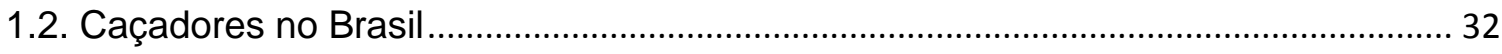

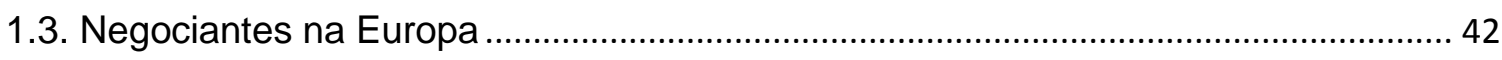

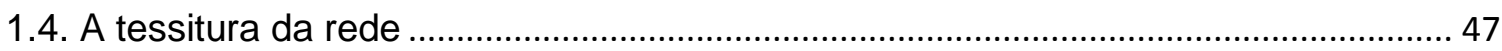

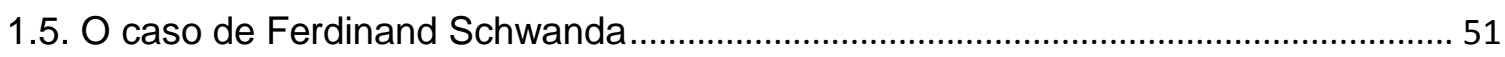

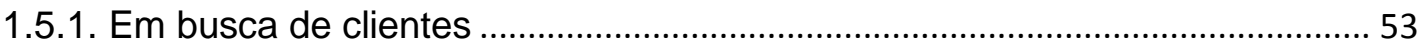

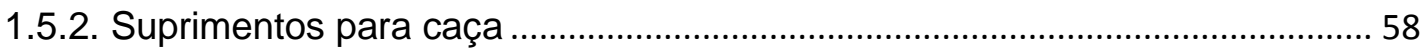

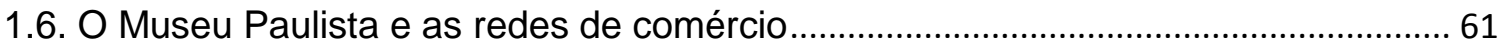

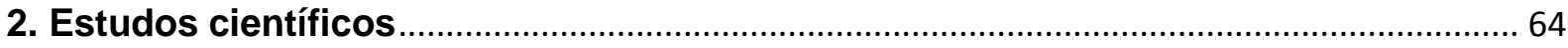

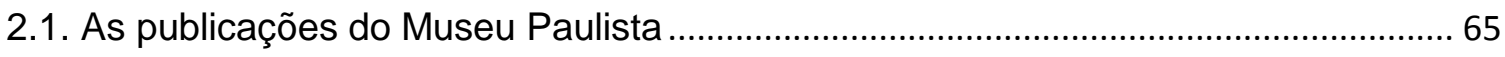

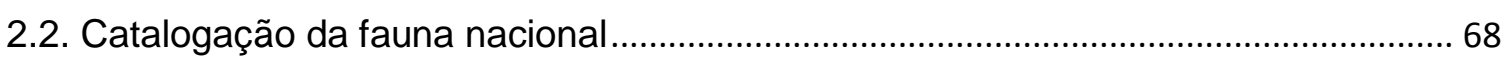

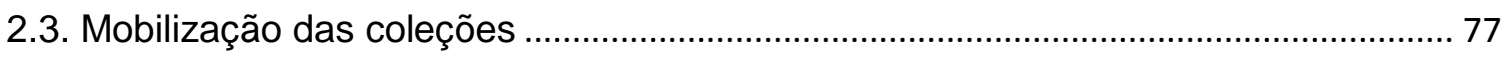

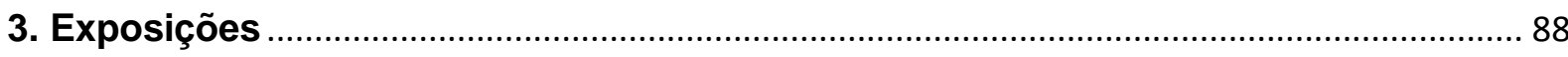

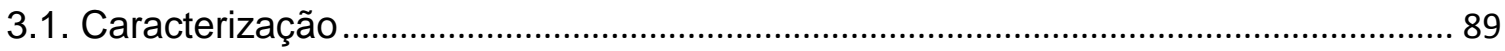

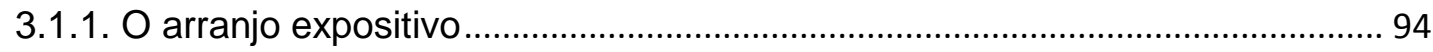

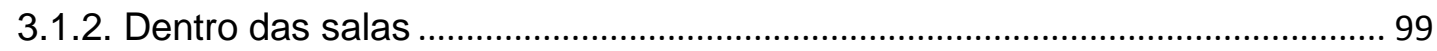

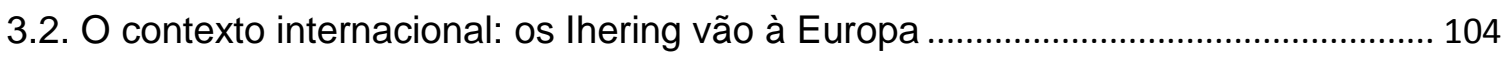

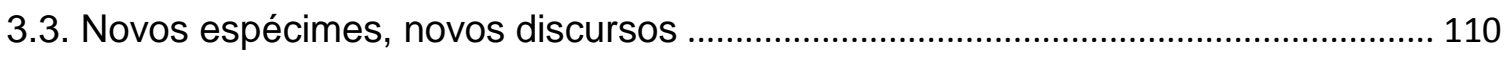

3.3.1. Do empalhamento ao método plástico ……................................................. 117

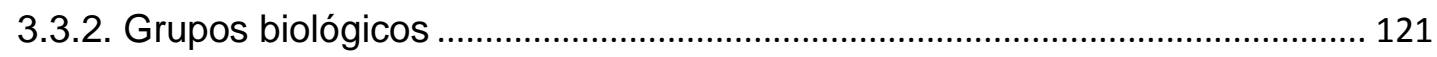

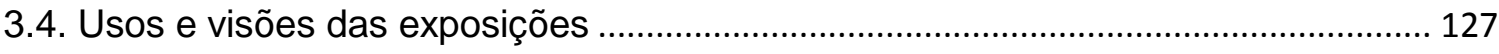

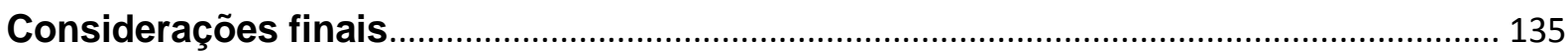

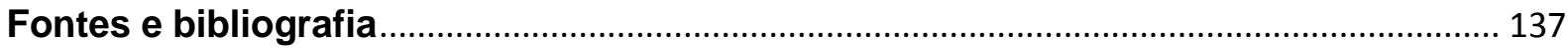

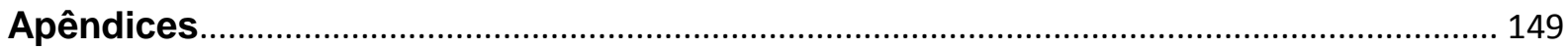

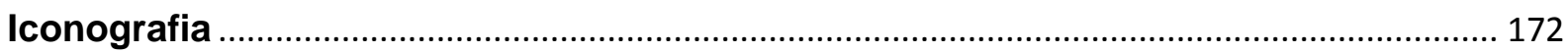




\section{Introdução}

No presente trabalho, parte-se do contexto de construção dos museus no Brasil do século XIX, tal como foi pioneiramente apresentado por Maria Margaret Lopes em sua investigação sobre a institucionalização das ciências naturais no Brasil. ${ }^{1}$ A partir desse patamar, objetiva-se empreender um estudo centrado nas coleções de História Natural do Museu Paulista, o que se dará por meio do aprofundamento no exame de alguns aspectos das práticas curatoriais ali desenvolvidas entre 1894 e 1916: aquisições, pesquisa e exposições públicas.

Nossa pesquisa pretende, dessa forma, somar-se aos estudos que abordaram a gestão de Hermann von Ihering à frente do Museu Paulista: além do próprio trabalho de Lopes (originalmente tese de doutorado defendida em 1993), os de Schwarcz (1993), Elias (1996), Alves (originalmente dissertação de mestrado defendida em 1998), Gualtieri (originalmente tese de doutorado defendida em 2001), Silva (2006) e Moraes (2008). Espera-se, assim, contribuir para o avanço na compreensão do que tenham sido a implantação e o desenvolvimento do primeiro museu público do estado de São Paulo. ${ }^{2}$

Ao investigar aspectos do primeiro museu público do estado, este trabalho pretende ainda se inserir na linha de pesquisa sobre História dos Museus e das Exposições que vem sendo desenvolvida por nossa orientadora, Heloisa Barbuy. Tal

\footnotetext{
${ }^{1}$ LOPES, Maria Margaret. O Brasil descobre a pesquisa científica: os museus e as ciências naturais no século XIX. São Paulo: Hucitec, 1997. (2 ${ }^{\mathrm{a}}$ ed. 2009). Originalmente Tese (Doutorado) defendida na Faculdade de Filosofia, Letras e Ciências Humanas da Universidade de São Paulo em 1993.

${ }^{2}$ LOPES, Maria Margaret. op. cit., 1997. SCHWARCZ, Lilia Moritz. O espetáculo das raças: cientistas, instituições e questões raciais no Brasil (1870-1930). São Paulo: Cia. das Letras, 1993. Originalmente Tese (Doutorado) defendida na Faculdade de Filosofia, Letras e Ciências Humanas da Universidade de São Paulo em 1992. ElIAS, Maria José. Museu Paulista: memória e história. São Paulo, 1996. Tese (Doutorado) - Faculdade de Filosofia, Letras e Ciências Humanas, Universidade de São Paulo. ALVES, Ana Maria de Alencar. O Ipiranga apropriado: ciência, política e poder: o Museu Paulista, 1893-1922. São Paulo: Humanitas/FFLCH-USP, 2001. Originalmente Dissertação (Mestrado) defendida na Faculdade de Filosofia, Letras e Ciências Humanas da Universidade de São Paulo em 1998. GuAltieRI, Regina Cândida Ellero. Evolucionismo no Brasil: ciência e educação nos museus, 1870-1915. São Paulo: Livraria da Física, 2008. Originalmente Tese (Doutorado) defendida na Faculdade de Filosofia, Letras e Ciências Humanas da Universidade de São Paulo em 2001. SILVA, Maurício Cândido da. Christiano Stockler das Neves e o Museu de Zoologia da Universidade de São Paulo. São Paulo, 2006. Dissertação (Mestrado) - Faculdade de Arquitetura e Urbanismo, Universidade de São Paulo. MORAES, Fábio Rodrigo de. Uma coleção de história em um museu de ciências naturais: o Museu Paulista de Hermann von Ihering. Anais do Museu Paulista, nova série, 16, 1, jan-jun. 2008, pp. 203-233.
} 
linha de pesquisa procura abarcar uma série de práticas expositivas, as quais podem ser aglutinadas sob a expressão cultura de exposições.

Em alguns trabalhos, Barbuy empregou essa expressão, cultura de exposições, para se referir aos diversos fenômenos culturais "baseados na linguagem didática da exibição organizada de coisas". ${ }^{3}$ Nesse sentido, mais do que um fenômeno restrito aos museus, a cultura de exposições é concebida pela autora como algo que engloba diversos elementos que marcaram a vida urbana das capitais europeias (e de outras partes do mundo) no longo séc. XIX: desde o surgimento e proliferação das vitrines de lojas, até as grandes exposições universais, passando por diversas mostras, demonstrações e espetáculos dos mais diversos tipos e escalas. ${ }^{4}$

As pesquisas que Barbuy vem desenvolvendo e orientando relacionam-se às diferentes dimensões dessa cultura de exposições: trabalhos sobre exposições universais e regionais, sobre a dimensão expositiva imbrincada nas práticas de urbanização e de comércio, bem como sobre museus e coleções. ${ }^{5}$

Nossa pesquisa, ao tratar do Museu Paulista de Hermann von Ihering, busca inserir-se no âmbito dessa linha de trabalhos sobre cultura de exposições. Todavia, procurou-se aqui, para além da questão expositiva, lidar com outras facetas do Museu. Facetas essas cujo exame é imprescindível se desejamos avançar na

\footnotetext{
${ }^{3}$ BARBUY, Heloisa. "Cultura de exposições em São Paulo, no século XIX". In: LOPES, Maria Margaret; HEIZER, Alda (orgs.). Colecionismos, práticas de campo e representações. Campina Grande: Eduepb, 2011, p. 257.

${ }^{4}$ Ver BARBUY, Heloisa, op. cit., 2011, pp. 257-268. BARBUY, Heloisa. "Museus, exposições e cidades: cultura visual no século XIX". In: OLIVEIRA, Cecilia Helena de Salles; BARBUY, Heloisa (orgs.). Imagem e produção de conhecimento. São Paulo: Museu Paulista/USP, 2002, pp. 66-78. BARBUY, Heloisa. "O campus do Ipiranga." In: LANA, Ana Lúcia Duarte. Cidades universitárias: patrimônio urbanístico e arquitetônico da USP. São Paulo: Edusp/Imprensa Oficial do Estado, 2005, p. 37.

${ }^{5}$ Cf. BARBUY, Heloisa. A Exposição Universal de 1889 em Paris: visão e representação na sociedade industrial. São Paulo: Loyola/História Social USP, 1999. Originalmente Dissertação (Mestrado) defendida na Faculdade de Filosofia, Letras e Ciências Humanas da Universidade de São Paulo em 1995; BARBUY, Heloisa. A cidade-exposição: comércio e cosmopolitismo em São Paulo, 1860-1914. São Paulo: Edusp, 2006. Originalmente Tese (Doutorado) defendida na Faculdade de Arquitetura e Urbanismo da Universidade de São Paulo em 2001; MORAES, Fábio Rodrigo de, op. cit., 2008, pp. 203-233; LIMA, Paula Coelho Magalhães de. A Exposição de 1917 em São Paulo: representações do industrialismo na metrópole nascente. São Paulo, 2008. Relatório de Iniciação Científica apresentado à Fapesp - Museu Paulista, Universidade de São Paulo; MARTINS, Mariana Esteves. A formação do Museu Republicano "Convenção de Itu" (1921-1946). São Paulo, 2012. Dissertação (Mestrado) Faculdade de Filosofia, Letras e Ciências Humanas, Universidade de São Paulo; CARVALHO, Paula Carolina de Andrade. O Museu Sertório: uma coleção particular em São Paulo no século XIX (primeiro acervo do Museu Paulista). São Paulo, 2013. Relatório de Iniciação Científica apresentado à Fapesp - Museu Paulista, Universidade de São Paulo.
} 
compreensão não apenas de suas exposições, mas de suas práticas curatoriais em sentido mais amplo.

Até porque as exposições dos museus não podem ser entendidas de forma totalmente alheia a suas atividades científicas. Barbuy já apontou a existência de:

(...) outros elementos relevantes, não diretamente ligados à cultura visual, e que devem ser considerados para que se possa atingir uma compreensão mais profunda do conceito de exposições, de sua função social e de seu papel nas dinâmicas da internacionalização cultural. Entre eles, a relação entre a cultura de exposições e a cultura científica do século XIX. ${ }^{6}$

Não se deve perder de vista que os museus de História Natural não se resumem a espaços onde o público pode visualizar, por meio de exposições de objetos, uma natureza ordenada segundo os critérios da ciência. Eles são também instituições incumbidas de formar e preservar coleções de objetos destinados a serem mobilizados para produção de conhecimentos em moldes considerados científicos.

Mas o que nos interessa sublinhar é que, tanto num caso (exposições) quanto noutro (produção de conhecimento), as coleções de objetos são centrais para esse modelo institucional. Afinal, os museus elaboram e veiculam conhecimentos sobre a natureza por meio dos objetos, dos espécimes científicos. Conforme Lopes:

Reunir coleções foi a razão de ser dos museus, uma vez que estas materializavam os próprios objetivos centrais da História Natural da época: mobilizar o mundo, classificá-lo e ordená-lo, nos espaços institucionais especialmente concebidos para tal fim, os museus. ${ }^{7}$

Toma-se como patamar de análise, portanto, que tais instituições não desempenham suas atividades de forma abstrata. Ao contrário, elas o fazem por meio de objetos palpáveis: os espécimes científicos - os quais são utilizados para produzir e veicular conhecimentos socialmente legitimados acerca da natureza.

\footnotetext{
${ }_{7}^{6}$ BARBUY, Heloisa, op. cit., 2011, p. 258.

7 Ibidem, p. 22.
} 
Desse modo, parece interessante atentar para esses objetos que constituem as coleções. É preciso investigar que objetos são esses, como são adquiridos, como são mobilizados para produzir conhecimentos e que representações veiculam.

Para contemplar tais pontos, pretendemos, nesta pesquisa, colocar as coleções de espécimes científicos no centro de nossa análise. Nesse sentido, nosso trabalho bebe nas linhas de pesquisa que vem sendo desenvolvidas por autores brasileiros e argentinos que lidam com a história dos museus de História Natural, como Lopes, Podgorny e Farro. Tais pesquisadores têm apontando e apostando a/na importância de investigações aprofundadas, capazes de capturar as complexidades envolvidas nas histórias dos museus - instituições cujas atuações iam muito além de apenas servir ao que seria um interesse dos Estados em reconhecer seu território e forjar identidades nacionais calcadas em representações da natureza. ${ }^{8}$

De forma mais específica, o trabalho se apropria das preocupações com os objetos e coleções que vêm sendo apontadas por alguns autores interessados na história dos museus. Esse é o caso de Lopes, que destaca o potencial analítico das trajetórias ou "biografias" de objetos e coleções:

Muito mais do que um modismo, tomar os objetos científicos, as coleções científicas, como 'sujeitos' cujas trajetórias merecem investigação, significa historiá-los. Como os objetos são centrais para as culturas dos museus, traçar suas biografias, suas trajetórias, se coloca como um instrumento poderoso de análise. ${ }^{9}$

É também o caso de Alberti, para quem traçar biografias de objetos significa examinar como o status de um artefato (aí incluídos os espécimes científicos) mudou ao longo de sua trajetória, desde o período anterior ao seu ingresso no museu até

\footnotetext{
${ }^{8}$ Sobre essas perspectivas de pesquisa, ver PODGORNY, Irina; LOPES, Maria Margaret. Trayectorias y desafíos de la historiografía de los museos de historia natural em América del Sur. Anais do Museu Paulista, nova série, 21, 1, jan-jun. 2013, pp. 15-25; e FARRO, Máximo. "Colecciones de cráneos, fotografías y manuscritos en el desarollo de la antropología física y de la etnografía lingüística em la Argentina a fines del siglo XIX". In: LOPES, Maria Margaret; HEIZER, Alda (orgs.). Colecionismos, práticas de campo e representações. Campina Grande: Eduepb, 2011, pp. 100-101.

${ }^{9}$ LOPES, Maria Margaret. "Trajetórias museológicas, biografias de objetos, percursos metodológicos". In: Almeida, Marta de; Vergara, Moema de Rezende (orgs.). Ciência, história e historiografia. São Paulo: Via Lettera; Rio de Janeiro: MAST, 2008, p. 309.
} 
sua exibição ao público. Trata-se, portanto, de observar as mudanças de valor e de significados atribuídos aos objetos durante sua trajetória.

Conforme 0 autor, estudos sobre aspectos dessas trajetórias podem contemplar análises a respeito de assuntos diversos, tais como: os motivos da coleta; os modos como os objetos chegaram até os museus (doação, compra, etc.); as redes de coletores que fornecem objetos/espécimes para os museus; o status peculiar adquirido por certos objetos em alguns museus; o papel do objeto na experiência dos visitantes do museu. ${ }^{10}$

Já Poulot - em texto mais preocupado com museus de Arte e de História, mas cujas considerações podem em parte ser estendidas a outras tipologias de museus - aponta a fecundidade de uma perspectiva histórica que, bebendo nos estudos de cultura material e sociologia dos objetos, volte-se menos para histórias institucionais e mais para o exame dos objetos de museu. ${ }^{11}$

Aqui, não pretendemos fazer "biografias" ou examinar trajetórias de objetos particularmente significativos das coleções do Museu Paulista. O que se pretende é examinar as principais etapas envolvidas na curadoria das coleções: a aquisição de objetos, sua mobilização para produção de conhecimento, sua exibição no âmbito das exposições públicas.

Ao investigar a aquisição dos objetos que compõem as coleções do Museu Paulista, bem como sua utilização para produção e veiculação de conhecimentos, o trabalho se aproxima de algumas perspectivas dos estudos de História da Cultura Material e da Cultura Visual. ${ }^{12}$ A pesquisa não deixa, todavia, de apresentar

\footnotetext{
10 AlberTI, Samuel J. M. M. Objects and the museum. Isis, 96, 4, 2005, pp. 559-560. Lopes desenvolve uma abordagem "biográfica" para tratar das coleções de conchas fósseis de Hermann von Ihering. Ver LOPES, Maria Margaret, op. cit., 2008, pp. 305-318. Outra análise de trajetória de material fóssil pertencente ao Museu Paulista é feita pela autora em LOPES, Maria Margaret. "Os catálogos de Hermann von Ihering: o archivo dos resultados obtidos na exploração científica do Brasil”. In: HeIzer, Alda; VIDEIRA, Antonio A. Passos (orgs.). Ciência, Civilização e República nos Trópicos. Rio de Janeiro: Mauad/Faperj, 2010, pp. 291-304. Estudos de caso tratando de trajetórias de espécimes zoológicos podem ser conferidos na coletânea organizada por ALBERTI, Samuel J. M. M. (org.). The Afterlives of Animals: A Museum Menagerie. Charlottesville and London: University of Virginia Press, 2011.

${ }_{11}$ POULOT, Dominique. Another History of Museums: from the Discourse to the Museum-Piece. Anais do Museu Paulista, nova série, 21, 1, jan-jun. 2013, pp. 27-47.

12 Considerações relevantes sobre esses campos podem ser conferidas em: MENESES, Ulpiano Toledo Bezerra de. A cultura material no estudo das sociedades antigas. Revista de História, 115, 1983, pp. 103-17; REDE, Marcelo. História a partir das coisas: tendências recentes nos estudos de cultura material. Anais do Museu Paulista, nova série, 4, 1996, pp. 265-282; MENESES, Ulpiano Toledo
} 
intersecção com a História das Ciências, com cuja bibliografia encontra interlocução necessária.

Aberto ao público em 1895, o Museu Paulista surgiu no bojo de um processo de ampliação dos espaços institucionais dedicados à ciência no estado de São Paulo. ${ }^{13} \mathrm{O}$ final do século XIX foi um período de crescimento acelerado do estado: os grandes dividendos provenientes da economia cafeeira se traduziram em processos de modernização e urbanização. Nesse cenário, a ampliação dos espaços científicos constituía não só uma aposta na capacidade da ciência para resolver problemas de ordem prática (agrícolas e de saúde pública), mas também um indicador simbólico da modernização e do cosmopolitismo almejados pelas elites políticas. Um museu, além de colaborar com o avanço do conhecimento científico e atender expectativas simbólicas, deveria cumprir um papel educativo, de instrução da população. ${ }^{14}$

A criação do Museu Paulista, todavia, não pode ser entendida apenas no âmbito dos interesses da administração pública e das elites políticas do estado. Como demonstraram Lopes e Figueirôa, os interesses de cientistas - muitas vezes estrangeiros ansiosos por fazer carreiras e angariar reputações nas jovens nações da América do Sul - devem ser levados em conta para se entender o surgimento e a trajetória de instituições desse tipo. Conforme as autoras, a atuação, junto ao poder público, do geólogo estadunidense Orville Derby - que então chefiava a Comissão

Bezerra de. Fontes visuais, cultura visual, História visual. Balanço provisório, propostas cautelares. Revista Brasileira de História, 23, 45, 2003, pp. 11-36; e KNAPPETT, Carl. Thinking through material culture: an interdisciplinary perspective. Philadelphia: University of Pennsylvania Press, 2005. Reflexões interessantes em torno do emprego de perspectivas dos estudos de Cultura Material e Cultura Visual em pesquisas sobre museus podem ser conferidas em HOOPER-GRENNHILL, Eilean. Museums and the Interpretation of Visual Culture. London: Routledge, 2000, pp.1-22 e pp. 103-123.

${ }_{13}$ Além do Museu, entre o final do século XIX e o princípio do XX foram criadas no estado as seguintes instituições: Instituto Agronômico de Campinas (1887), Instituto Bacteriológico de São Paulo (1892); Instituto Histórico e Geográfico de São Paulo (1893); Escola Politécnica (1895); Instituto Butantan (1901); e Instituto Pasteur (1903). Além disso, cabe destacar a criação da Comissão Geográfica e Geológica (1886), instituição da qual, como veremos, desmembrou-se o próprio Museu Paulista.

${ }^{14}$ Ver ALVES, Ana Maria de Alencar. op. cit., 2001. 
Geográfica e Geológica de São Paulo - foi fundamental seja para a criação do Museu, seja para a contratação de Ihering para dirigi-lo. ${ }^{15}$

O acervo inicial do Museu era formado essencialmente por uma antiga coleção particular conhecida como Museu Sertório - assim chamada porque pertencia ao Coronel Joaquim Sertório, comerciante abastado residente na cidade de São Paulo na segunda metade do século XIX, famoso justamente por sua enorme coleção. Constituído pelos mais variados objetos - incluindo espécimes zoológicos e botânicos, amostras de minerais, artefatos etnológicos e históricos, além de coleção numismática - o Museu Sertório foi, em fins de 1890, comprado pelo Conselheiro Francisco de Paula Mayrink e oferecido ao governo do estado juntamente com outra pequena coleção particular conhecida como Pessanha. ${ }^{16}$

Para gerir esse acervo, que em breve passaria a ser conhecido como Museu do Estado, foi nomeado como diretor interino, no ano de 1891, o botânico Alberto Löfgren. ${ }^{17}$ Entre 1892 e 1894, o Museu tornou-se uma instituição autônoma (subordinada à Secretaria do Interior) - após passar curto período como anexo da Comissão Geográfica e Geológica de São Paulo -, teve Hermann von Ihering nomeado seu diretor e passou a ocupar o Monumento do Ipiranga. ${ }^{18}$

Antes de ocupar o Monumento, o Museu havia sido abrigado em algumas outras edificações: em dezembro de 1892, a instituição - até então sediada num

\footnotetext{
${ }^{15}$ Ver LOPES, Maria Margaret, op. cit., 1997, pp. 265-269; FIGUEIRÔA, Silvia Fernanda de Mendonça. As ciências geológicas no Brasil: uma história social e institucional, 1875-1934. São Paulo: Hucitec, 1997, pp. 143-148; LOPES, Maria Margaret; FIGUEIRÔA, Silvia Fernanda de Mendonça. A criação do Museu Paulista na correspondência de Hermann von Ihering (1850-1930). Anais do Museu Paulista, nova série, 10/11, 2002-2003, pp. 23-35.

${ }^{16}$ Ver LOPES, Maria Margaret, op. cit., 1997, pp. 265-267. ELIAS, Maria José, op. cit., 1996. ALVES, Ana Maria de Alencar, op. cit., 2001, pp. 56-68. Ofícıo de Orville Derby a Hermann von Ihering, São Paulo, 29/08/1895, reproduzido em IHERING, Hermann von. Historia do Monumento do Ypiranga e do Museu Paulista. Revista do Museu Paulista, 1, 1895, pp. 13-15. Um novo olhar sobre o Museu Sertório pode ser conferido no trabalho de Paula Carvalho. A autora apresenta um quadro bastante detalhado e ricamente documentado do Coronel Joaquim Sertório e seu museu, bem como uma análise dessa coleção como fenômeno situado na confluência entre tradições colecionistas pósrenascentistas e padrões científicos do século XIX. Ver CARVALHO, Paula Carolina de Andrade, op. cit., 2013.

${ }_{17}$ Por vezes, o nome do naturalista, nascido na Suécia, é grafado "Loefgren".

${ }^{18}$ LOPES, Maria Margaret, op. cit. 1997, pp. 265-267. ALVES, Ana Maria de Alencar, op. cit., 2001, pp. 56-68. MAKINO, Miyoko. Cronologia do Museu Paulista/USP. Diário Oficial do Estado de São Paulo, 107, 220, 15 nov. 1997, p. 1. Ofíclo de Orville Derby a Hermann von Ihering, São Paulo, 29/08/1895, reproduzido em IHERING, Hermann von. Historia do Monumento do Ypiranga e do Museu Paulista. Revista do Museu Paulista, 1, 1895, pp. 13-15. Tomamos o ano de 1894 como marco inicial de nosso estudo, já que em 15 de janeiro desse ano Hermann von Ihering foi nomeado diretor do Museu autônomo - não mais subordinado à Comissão Geográfica. Ver MAKINO, Miyoko, op. cit., 1997, p. 1.
} 
prédio no Largo Municipal (mais tarde Praça João Mendes) - foi transferida para um edifício no Largo do Palácio (atual Pátio do Colégio). Em 1893, com a anexação do Museu à Comissão Geográfica e Geológica, o acervo foi transferido mais uma vez, agora para um edifício na Rua da Consolação, que também serviria de sede para a Comissão. $^{19}$

Durante o período correspondente à gestão de Hermann von lhering, ${ }^{20}$ entre 1894 e 1916, a instituição configurou-se como um museu multidisciplinar. ${ }^{21}$ Apresentava coleções de Zoologia, Botânica, Mineralogia, Paleontologia, Arqueologia, Etnologia e História. No entanto, a Zoologia ocupava um papel primordial no Museu: além de a maior parte das salas de exposição ser dedicada a ela, os esforços de aquisição de peças para as coleções de estudo, bem como a mobilização dessas peças para estudos científicos, envolviam principalmente as coleções zoológicas, embora não somente. ${ }^{22}$

Nesse período de pouco mais de vinte anos em que lhering esteve à frente do Museu Paulista, a instituição alcançou, conforme pretendemos deixar claro ao longo desta dissertação, uma série de avanços. Conseguiu formar coleções significativas, colaborar com o avanço do conhecimento de ao menos alguns dos domínios da História Natural, além de ter procurado desenvolver um discurso expositivo em consonância com o que era feito nos museus das grandes capitais mundiais.

Conforme já apontamos, o Museu Paulista foi, nas últimas décadas, de forma direta ou indireta, objeto de alguns estudos históricos, aos quais este vem se seguir.

\footnotetext{
${ }^{19}$ Ver Ofícıo de Orville Derby a Hermann von Ihering, São Paulo, 29/08/1895, reproduzido em IHERING, Hermann von. Historia do Monumento do Ypiranga e do Museu Paulista. Revista do Museu Paulista, 1, 1895, pp. 13-15. Sobre a Comissão Geográfica, ver FIGUEIRÔA, Silvia Fernanda de Mendonça. Modernos Bandeirantes: a Comissão Geográfica e Geológica de São Paulo e a exploração científica do território paulista. São Paulo, 1987. Dissertação (Mestrado) - Faculdade de Filosofia, Letras e Ciências Humanas, Universidade de São Paulo; e FIGUEIRÔA, Silvia Fernanda de Mendonça, op. cit., 1997, pp. 187-216.

${ }^{20}$ Sobre aspectos biográficos de Ihering, ver LOSANO, Mario G. Um precursor da ecologia no Brasil: Hermann von Ihering. Trad. Giacomina Faldini. Revista USP, 13, 1992, pp. 88-99.

${ }^{21}$ Preferimos utilizar o termo "multidisciplinar" ao invés de "enciclopédico", já que o Museu Paulista, embora agregasse coleções pertinentes a diferentes áreas do conhecimento, pretendia ser uma instituição especializada em coleções sul-americanas (com ênfase nas brasileiras e paulistas), ao invés de reunir acervos provenientes de todas as partes do globo. Uma discussão sobre as concepções de Ihering acerca dos museus centrais e especializados (geográfica e tematicamente) pode ser conferida em LOPES, Maria Margaret, op. cit., 1997, pp. 287-291.

${ }^{22}$ A gestão Ihering é tradicionalmente vista como a fase em que o Museu era essencialmente uma instituição dedicada à História Natural, particularmente à Zoologia. Todavia, o papel das demais coleções não deve ser desprezado, conforme ressalta Moraes no que se refere às coleções de História Pátria. Ver MORAES, Fábio Rodrigo de, op. cit., 2008.
} 
Referindo-se especificamente à gestão Ihering, podemos citar os estudos de Lopes, Schwarcz, Elias, Alves, Gualtieri, Silva e Moraes.

O trabalho de Lopes trata dos museus de História Natural no Brasil desde 0 início do século XIX até o princípio do XX, abordando-os como espaços em que se deu a institucionalização das ciências naturais no país. Nesse trabalho referencial, a autora examina tanto os perfis das instituições quanto os redirecionamentos pelos quais passaram ao longo do período estudado. Vale ressaltar a atenção que o trabalho confere às coleções dos museus - assunto que é particularmente relevante para nossa pesquisa -, procurando caracterizá-las, dimensioná-las e observar seus modos de aquisição.

No que se refere especificamente ao Museu Paulista, a autora o examina desde sua criação até o final da gestão lhering. Ampla gama de aspectos é analisada ou abordada. Podemos citar: processos de aquisição de espécimes; corpo funcional e cientistas colaboradores externos; intercâmbios com instituições estrangeiras; a produção científica da instituição veiculada por meio da Revista do Museu Paulista; viagens realizadas pelo corpo científico do Museu para visitar instituições congêneres no exterior. Além disso, trata das concepções de lhering acerca da organização que os museus deveriam apresentar. ${ }^{23}$

Já a obra de Schwarcz, estudo dedicado a historiar as teorias raciais no Brasil, aborda o Museu Paulista da fase Ihering no tocante aos discursos raciais produzidos no âmbito da instituição - particularmente pelos estudos antropológicos publicados por Ihering na Revista do Museu Paulista. ${ }^{24}$

Outro trabalho, o de Elias, mesmo particularmente interessado na problemática do Museu Paulista enquanto lugar dedicado à memória nacional, traz um capítulo sobre o período de lhering à frente da instituição. Nesse capítulo, apresenta um panorama dessa gestão, destacando cronologicamente os principais acontecimentos, além de exibir um rol das instituições com as quais o Museu trocou correspondências. Embora faça referência a aspectos da formação das coleções -

\footnotetext{
${ }^{23}$ LOPES, Maria Margaret, op. cit., 1997.

24 SCHWARCZ, Lilia Moritz, op. cit., 1993.
} 
como os trabalhos do naturalista viajante Ernesto Garbe, bem como a compra de espécimes - as coleções e exposições não estão no seu foco de análise. ${ }^{25}$

Já o estudo de Alves, que trata do Museu Paulista no período compreendido entre 1893 (ano de sua criação) e $1922,{ }^{26}$ tem como foco a questão da educação. A autora defende que a criação do Museu Paulista esteve vinculada aos projetos das elites republicanas, as quais almejavam, com a criação de um museu de História Natural, contribuir para a modernização de São Paulo por meio da educação. Alves insiste no papel da instrução no âmbito do Museu, salientando que, por meio dela, a instituição se inseria no bojo das preocupações civilizatórias que marcaram a primeira República.

Quanto às atividades científicas, a obra dá um panorama das diversas disciplinas contempladas pelas atividades do Museu, apresentando informações que permitem que se tenha uma ideia geral do teor das coleções da instituição. Trata ainda, brevemente, dos processos de aquisição de exemplares para as coleções: compra, permuta, doação e excursões científicas de funcionários do Museu. Todavia, o estudo de Alves não tem por objeto central as coleções propriamente ditas - já que se ocupa de outras questões.

Gualtieri, por sua vez, examina como as ideias evolucionistas foram instrumentalizadas pelos cientistas ligados aos museus de História Natural brasileiros, entre as décadas finais do século XIX e as primeiras do XX. Analisando principalmente os trabalhos veiculados nos periódicos publicados pelo Museu Nacional, Museu Paraense e Museu Paulista, a autora aborda o modo como as ideias evolucionistas, em suas diferentes orientações teóricas, foram empregadas por esses cientistas para propor questões e desenvolver análises dentro das diversas áreas abrangidas pelas ciências naturais.

No caso do Museu Paulista, Gualtieri, ao analisar a revista publicada pela instituição, detêm-se particularmente nas produções de Hermann e Rodolpho von

\footnotetext{
${ }^{25}$ ELIAS, Maria José, op. cit., 1996.

${ }^{26}$ Isso abrange a fase Ihering (1894-1916), quando a instituição era predominantemente um museu de História Natural, e o período inicial da gestão Taunay, que corresponde ao início do processo que elevaria a História do Brasil de coadjuvante a ator principal no interior do Museu - embora isso não significasse, como indica a autora, que a História Natural tenha sido varrida do Museu Paulista assim que Taunay passou a dirigir a instituição. Cf. ALVES, Ana Maria de Alencar, op. cit., 2001.
} 
Ihering no periódico, procurando observar como cada um deles se utilizava, em seus trabalhos científicos, de referenciais darwinistas de diferentes matizes. ${ }^{27}$

Já o trabalho de Silva tem como foco o projeto arquitetônico de Christiano Stockler das Neves para o prédio do Museu de Zoologia da USP - instituição, desmembrada do Museu Paulista em 1939, que herdou as coleções e a estrutura da área de Zoologia do último. No entanto, buscando entender como o perfil adquirido pela área de Zoologia do Museu Paulista ao longo de décadas influenciou no projeto de um novo edifício, o autor também trata da história do Museu Paulista, inclusive durante a gestão Ihering. Particularmente interessante é o exame que faz da implantação de um Horto Botânico no terreno situado atrás do edifício do Museu. ${ }^{28}$

Já Moraes realiza um estudo detalhado sobre o papel das coleções de História durante a gestão Ihering, lançando, desse modo, um novo olhar sobre essa fase do Museu. O autor demonstra, contrariando a historiografia anterior, que as coleções de História tiveram um papel importante durante a gestão lhering. ${ }^{29}$

No que se refere a estudos sobre a história dos museus e coleções de História Natural em geral, vale ressaltar que, nas últimas décadas, trabalhos sobre essas temáticas vêm ganhando impulso, conformando para alguns uma área específica de pesquisa. ${ }^{30}$

Tais estudos, sejam monografias, ${ }^{31}$ sejam trabalhos que lidam com o assunto de forma não localizada, abordam a temática segundo diversas perspectivas. Muitos deles tratam do papel dos museus na sociedade, analisando, por meio de enfoques foucaultianos, aspectos de disciplina e poder. ${ }^{32}$ Outros examinam essas instituições

\footnotetext{
${ }^{27}$ GuALTIERI, Regina Cândida Ellero, op. cit., 2008.

${ }^{28}$ SILVA, Maurício Cândido da, op. cit., 2006.

${ }^{29}$ MORAES, Fábio Rodrigo de, op. cit., 2008.

${ }^{30}$ Cf. LOPES, Maria Margaret, op. cit., 2008, p. 306.

${ }^{31}$ São inúmeros os trabalhos sobre a história de instituições específicas. A título de exemplo, citamos apenas alguns que, de forma indireta, foram úteis para nossa pesquisa, mas que não serão citados (ou serão poucos citados) no decorrer do trabalho: DIAS, Nélia. Le Musée d'Ethnographie du Trocadéro (1878-1908): Anthropologie et Muséologie en France. Paris: CNRS, 1991; ALBERTI, Samuel J.M.M. Nature and Culture: Objects, Disciplines and the Manchester Museum. Manchester: Manchester University Press, 2009; SANJAD, Nelson. A Coruja de Minerva: o Museu Paraense entre o Império e a República (1866-1907). Brasília: Instituto Brasileiro de Museus; Rio de Janeiro: Fundação Oswaldo Cruz, 2010.

${ }^{32}$ ALBERTI, Samuel J. M. M., op. cit., 2005, pp. 559-560.
} 
enquanto locais em que se processam e se desenvolvem ideias sobre gênero, raça, etnicidade e classe. ${ }^{33}$

O estudo de museus e coleções tem se mostrado igualmente relevante nas análises sobre o papel do conhecimento científico na construção dos impérios neocoloniais. ${ }^{34}$ Outra corrente fértil tem se dedicado ao estudo dos edifícios de museus, analisando seus projetos arquitetônicos e usos do espaço. ${ }^{35}$

Para nossa pesquisa, foram particularmente elucidativos os trabalhos de Nyhart e Köstering. O primeiro, por nos permitir compreender as relações entre os museus de História Natural e a reconfiguração de paradigmas disciplinares entre o final do século XIX e o princípio do XX. A autora, tratando do contexto alemão, examina a chamada perspectiva biológica (biological perspective), que é por ela entendida tanto como um enquadramento teórico para as pesquisas científicas, quanto uma percepção acerca do funcionamento da natureza partilhada por um espectro social bem mais amplo do que apenas o dos cientistas. Seria um modo de conceber a natureza, portanto, diferente de uma perspectiva taxonômica, que a entende como um conjunto de elementos sistematicamente ordenados por afinidades e semelhanças de forma, e diferente ainda da perspectiva evolutiva, que atribui essas afinidades a relações de descendência.

Nyhart trata da perspectiva biológica em diversos âmbitos. Investiga seu surgimento em meio a taxidermistas e outros naturalistas práticos; o papel dos jardins zoológicos em sua formulação; sua disseminação pelo ensino básico de ciências; sua elaboração teórica por Karl Möbius por meio do conceito de Lebensgemeinschaft (algo como "comunidade viva"); e como ela ganha as exposições dos museus de História Natural por meio dos grupos biológicos. ${ }^{36} \mathrm{Em}$ capítulo dedicado especificamente ao exame dos grupos biológicos, a autora

\footnotetext{
33 KOHLSTEDT, Sally Gregory. "Thoughts in Things" - Modernity, History, and North American Museums. Isis, 96, 4, 2005, pp. 594.

${ }^{34}$ ALBERTI, Samuel J. M. M., op. cit., 2005, pp. 559-560.

${ }^{35}$ Ver KOHLSTEDT, Sally Gregory; BRINKMAN, Paul. Framing Nature: the formative years of natural history museum development in the United States. Proceedings of the California Academy of Sciences, 55, supplement I, Out. 2004, pp. 7-33. Ver ainda FORGAN, Sophie. Building the museum knowledge, conflict and the power of place. Isis, 96, 4, 2005, pp. 572-585.

${ }^{36}$ NYHART, Lynn K. Modern Nature: The Rise of the Biological Perspective in Germany. Chicago: University of Chicago Press, 2009.
} 
examina as diferentes tipologias dessa solução expográfica, bem como as várias funções por ela cumpridas ou os diferentes discursos por ela veiculados. ${ }^{37}$

Já o trabalho de Köstering possibilitou-nos compreender o processo de diversificação pelo qual passaram os discursos expositivos dos museus de História Natural entre a segunda metade do século XIX e o começo do XX. A autora se ocupa das exposições de Zoologia dos museus de História Natural alemães entre 1871 e 1914, examinando a mudança de paradigma que as marca nesse período mudança por ela denominada de virada biológica (Biologische Wende), e que de algum modo corresponde ao que Nyhart nomeia perspectiva biológica. Essa virada biológica caracterizou-se, no âmbito das exposições, pela perda de espaço da Taxonomia em relação à Biologia e à Ecologia enquanto princípio organizador embora a primeira não desapareça, ao contrário, persista como pano de fundo. Montagens visando explicitar o comportamento e a vida social dos animais passaram então a ser cada vez mais comuns nas exposições.

Relevante para nosso trabalho é que a autora detém-se na análise das exposições mais representativas das diferentes tendências desse movimento de mudança que vinha marcando os museus de História Natural no período estudado como as exposições do Museum für Naturkunde de Berlim, do Altonaer Museum e do Lepziger Naturkundliche Heimatmuseum. Köstering discorre sobre as diferenças entre cada uma dessas exposições: as variações na disposição do mobiliário, nas concepções sobre grupos biológicos, bem como as diferentes perspectivas científicas e os diferentes modos de ver embutidos em cada uma delas. ${ }^{38}$

Dado o estado atual dos estudos sobre o Museu Paulista, bem como a relativa diversidade de perspectivas dos estudos sobre museus e coleções publicados nos últimos anos, entendemos que uma análise do Museu voltada para a história de suas coleções pode trazer contribuições novas e interessantes.

\footnotetext{
${ }^{37}$ NYHART, Lynn K, op. cit., 2009, pp. 251-292. Sobre grupos biológicos, ver os itens 3.2 e 3.3 desta dissertação.

${ }^{38}$ KöSTERING, Susanne. Natur zum Anschauen: das Naturkundemuseum des deutschen Kaiserreichs 1871-1914. Köln: Böhlau, 2003.
} 
Embora a história da instituição tenha sido já objeto de alguns estudos, o papel de suas coleções de História Natural ainda não foi esgotado. Por isso, optamos por realizar um estudo minucioso acerca da história dessas coleções, contemplando processos de aquisição de acervo e seu uso científico e expositivo. Esperamos, assim, gerar contribuições relevantes para a história das práticas culturais na passagem do século XIX para o XX.

Parta tanto, foi necessário investigar, com novos olhares, conjuntos documentais já examinados por outros autores: os artigos científicos e relatórios administrativos veiculados na Revista do Museu Paulista; e a documentação de caráter burocrático produzida ou acumulada pelo Museu no âmbito de suas rotinas administrativas.

Quanto ao último conjunto, algumas palavras mais se fazem necessárias. A documentação institucional encontra-se hoje armazenada no Serviço de Documentação Textual e Iconografia do Museu Paulista da USP, sob a rubrica Arquivo Permanente do Museu Paulista/Fundo Museu Paulista. Particularmente férteis para nossa pesquisa foram: os ofícios trocados com a Secretaria do Interior órgão ao qual se subordinava o Museu Paulista durante a maior parte da gestão Ihering; a documentação financeira referente à compra de produtos de História Natural pelo Museu; as fotografias dos espaços expositivos.

Além desses conjuntos documentais produzidos pela própria instituição, outros, externos, foram utilizados: os jornais Correio Paulistano e O Estado de $S$. Paulo; as revistas Chacaras e Quintaes e O Entomologista Brasileiro; a Coleção Alexandre Hummel (Serviço de Documentação Textual e Iconografia do Museu Paulista da USP); além de relatos de cronistas e viajantes que visitaram o Museu durante o período lhering.

Como em qualquer trabalho deste tipo, uma série de opções e recortes foi feita, alguns dos quais merecem sucintas explicações. Primeiramente, optamos por tratar essencialmente das coleções zoológicas - embora eventualmente sejam feitas referências a aspectos das coleções pertinentes às demais disciplinas abrangidas pelo Museu. A escolha se deve ao fato de a Zoologia ser a principal área à qual se dedicava o Museu: os esforços para aquisição de coleções recaíam principalmente sobre os espécimes zoológicos; a maior parte dos estudos veiculados na revista da 
instituição era de Zoologia; a maior parte da superfície dedicada às exposições era tomada por espécimes zoológicos.

Segundo, ao tratar da mobilização das coleções do Museu (seja para produzir conhecimento, seja para elaborar exposições), nossas análises privilegiaram as coleções de Ornitologia e Mastozoologia. Isso se deve, por um lado, ao fato de as exposições de aves e mamíferos ocuparem a maior superfície do espaço destinado às exposições. Por outro lado, ao fato de encontramos no âmbito dessas coleções os exemplos mais elucidativos de emprego de espécimes para produção de conhecimento e de tentativa de sofisticação dos discursos expositivos do Museu. Embora outros grupos, como moluscos e insetos, tenham sido objetos de vastos estudos por parte de, respectivamente, Hermann e Rodolpho von Ihering, não encontramos, nesses trabalhos, passagens que explicitassem tão bem os modos de utilização dos espécimes para produção de conhecimento.

Terceiro, optamos por explicitar alguns conceitos e procedimentos das ciências zoológicas tal qual eram praticadas no Museu Paulista - isso é particularmente válido para o segundo capítulo desta dissertação. Embora alguns desses conceitos e procedimentos possam ser intrínsecos ao trabalho dos zoólogos sistematas ainda hoje, fez-se necessário explicitá-los, uma vez que este é um trabalho no campo da História da Cultura e que esperamos, ao problematizar certas práticas, melhor compreender e historicizar as coleções de História Natural.

Quarto, a opção, ao tratar dos processos de aquisição de espécimes, de nos debruçarmos exclusivamente sobre as aquisições por meio de compra, fez com que nossa pesquisa deixasse de contemplar aspectos importantes envolvidos na obtenção de coleções. O exame das permutas realizadas e das doações recebidas pelo Museu ensejaria, entre outras coisas, uma compreensão dos diálogos mantidos com instituições e pesquisadores do Brasil e da América Latina - e não apenas da Europa. ${ }^{39}$ Por sua vez, a análise das coletas efetuadas pelo próprio corpo de funcionários do Museu - com destaque para o trabalho monumental efetuado pelo naturalista viajante Ernesto Garbe - propiciaria um quadro talvez mais fidedigno do

\footnotetext{
${ }^{39}$ Lopes e Figueirôa indicam a ampla rede de relações que o Museu travava com instituições da América do Sul e apontam a importância de se observar as relações mantidas com instituições e pesquisadores do Brasil e da América Latina. Ver LOPES, Maria Margaret, op. cit., 1997, p. 274 e p. 281; LOPES, Maria Margaret; FIGUEIRÔA, Silvia Fernanda de Mendonça, op. cit., 2002-2003.
} 
que foi a formação das coleções zoológicas do Museu Paulista. No entanto, conforme argumentaremos de forma mais detalhada no capítulo pertinente, a análise das estratégias envolvidas na compra de produtos de História Natural deu ensejo à compreensão de processos especialmente interessantes para os objetivos desta pesquisa.

A dissertação foi divida em três capítulos. O primeiro trata de alguns processos de aquisição de espécimes científicos por parte do Museu Paulista. Mais especificamente, investigamos as relações comerciais mantidas entre o Museu e negociantes de espécimes científicos - tanto aqueles sediados no exterior quanto os residentes no Brasil. Por meio do exame de tais relações, procuramos analisar como - Museu articulava esses atores de modo a fomentar a ação de comerciantes nacionais, fortalecendo assim um mercado que lhe permitia adquirir espécimes para suas atividades científicas e expositivas.

O segundo capítulo aborda a utilização dos espécimes para produção de conhecimento. Examinando os estudos científicos realizados com base em materiais das coleções do Museu, procuramos entender o papel desses objetos na produção de inventários faunísticos e nos trabalhos de revisão taxonômica.

O terceiro capítulo trata das exposições de Zoologia do Museu. Examinamos, com algum nível de detalhe, o que estava exposto e como estava exposto, além de observarmos as inovações expositivas elaboradas em consonância com o que vinha sendo desenvolvido nos museus das grandes capitais mundiais. Procuramos, assim, compreender como, por meio da mobilização de espécimes científicos, o Museu foi capaz de veicular conhecimentos sobre a fauna do país. 


\section{O comércio internacional de objetos de História Natural}

Durante o período abrangido por esta pesquisa, 1894-1916, o Museu Paulista, assim como seus congêneres nacionais e estrangeiros, tinha como uma de suas principais funções colecionar amostras da natureza. Adquirir, preparar e conservar esses objetos eram as tarefas de base da instituição. Só assim, formando acervos de dimensão considerável, era possível dispor de materiais para produzir e veicular conhecimentos sobre a natureza do país.

No entanto, a coleta de amostras do mundo natural não deve ser tomada como uma prática neutra. Ao contrário, ela é produto dos interesses científicos de determinadas instituições e pesquisadores, e simultaneamente elemento condicionador do tipo de conhecimento que será produzido. Examinando o caso da emergência da medicina tropical no Brasil, Sá sugere que a descoberta, na segunda metade do século XIX, de invertebrados vetores de doenças redirecionou “(...) o olhar dos coletores para grupos de animais até então negligenciados pelos museus de História Natural". ${ }^{40}$ E se o desenvolvimento dessa entomologia médica foi responsável por gerar modificações nas práticas de coleta, ao mesmo tempo, são as coleções formadas que possibilitaram o desenvolvimento dos conhecimentos sobre as doenças tropicais. ${ }^{41}$

Neste capítulo, o que faremos é examinar algumas estratégias de aquisição de coleções colocadas em prática pelo Museu Paulista. Para dar conta de paradigmas científicos e agendas de pesquisa que demandavam mobilizar séries de animais (diversos exemplares da mesma espécie), bem como espécimes provenientes de diferentes pontos geográficos do estado, do país e da América do Sul, ${ }^{42}$ o Museu precisou travar relações com diversos coletores capazes de fornecer, em troca de dinheiro, os espécimes por ele requeridos.

\footnotetext{
${ }^{40}$ SÁ, Magali Romero. "A ciência, as viagens de coleta e as coleções: medicina tropical e o inventário da história natural na Primeira República". In: HeIZER, Alda; VIDEIRA, Antonio A. Passos (orgs.). Ciência, Civilização e República nos Trópicos. Rio de Janeiro: Mauad/Faperj, 2010, p. 227.

${ }^{41}$ Ibidem, pp. 227-243.

${ }^{42}$ Conforme o Regulamento do Museu, fixado pelo Decreto n. 249, de 26 de julho de 1894, "O caráter do Museu em geral será o de um museu sul-americano, destinado ao estudo do reino animal, de sua história zoológica e da história natural e cultural do homem." Segundo Ihering, "O fim destas coleções [do Museu] é dar uma boa e instrutiva ideia da rica e interessante natureza da América do Sul e do
} 
Como pretendemos demonstrar ao longo deste texto, o Museu Paulista manteve contatos com negociantes de espécimes atuantes no Brasil e na Europa. Mais do que isso, a instituição encarregou-se de costurar uma rede de relações comerciais, o que lhe possibilitou obter os meios necessários para construir e veicular conhecimentos sobre a natureza.

Analisaremos, portanto, neste capítulo, essas relações comerciais mantidas entre o Museu Paulista e negociantes de espécimes científicos - tanto aqueles sediados no exterior quanto os residentes no Brasil - durante a gestão de Hermann von Ihering. Almejamos, dessa forma, compreender como o Museu articulava esses atores de modo a fomentar a ação de comerciantes atuantes em território brasileiro, fortalecendo assim um mercado que the permitia adquirir espécimes para suas atividades científicas e expositivas.

Como se vê, optamos por analisar os processos de obtenção de material científico por meio compra, em detrimento de outras formas de aquisição. Embora a maior parte dos espécimes incorporados às coleções tenha sido coletada por funcionários do Museu (em particular o naturalista viajante), o comércio constituiu uma via privilegiada para que a instituição pudesse complementar suas coleções, obtendo materiais raros ou de diversas regiões do Brasil e da América do Sul. Cabe dizer ainda que a utilização da compra como estratégia sistemática de aquisição de espécimes talvez tenha sido, entre os museus brasileiros, uma peculiaridade do Museu Paulista. ${ }^{43}$

Brasil em especial, como do homem sul-americano e de sua história." IHERING, Hermann von. Historia do Monumento do Ypiranga e do Museu Paulista. Revista do Museu Paulista, 1, 1895, p. 20. Optamos por atualizar a grafia dos trechos de documentos citados ao longo do trabalho, a não ser os títulos de publicações.

${ }^{43}$ Segundo Lopes, talvez o Museu Paulista tenha adquirido muito mais coleções por compra do que os demais museus do país. Ver LOPES, Maria Margaret, op. cit., 1997, p. 272 e p. 281. Gottfried Hagmann (1874-1946), Auxiliar Científico e Inspetor do Jardim Zoológico do Museu Goeldi (Belém PA) entre 1899 e 1904, ao tratar da aquisição de animais vivos para o Parque Zoobotânico do museu paraense, afirma que, diferente da maior parte dos jardins zoológicos, o Parque obtinha a maior parte de seus animais não por compra, mas por meio de capturas realizadas diretamente na natureza por seus próprios funcionários. Ver SANJAD, Nelson et al. Documentos para a história do mais antigo jardim zoológico do Brasil: o Parque Zoobotânico do Museu Goeldi. Boletim do Museu Paraense Emílio Goeldi. Ciências Humanas, 7, 1, jan.-abr. 2012, pp. 212-219. Esse trabalho, além de uma contextualização da criação do Parque Zoobotânico, apresenta traduções, do alemão para o português, efetuadas por Miriam Junghans, de dois importantes documentos: os relatórios técnicos dos responsáveis pela gestão do Parque, os zoólogos Hermann Meerwarth e Gottfried Hagmann. As estratégias de formação de coleções variavam entre os museus. Conforme demonstra SheetsPyenson, em sua análise comparativa de museus de História Natural de quatro países ( Argentina, Austrália, Canadá e Nova Zelândia), alguns museus eram fortemente dependentes de doações, 
Além disso, examinando tais relações comerciais entre revendedores, caçadores e instituições - e a atuação fomentadora de Ihering - poderemos compreender a construção dessa rede que possibilitava ao Museu não só adquirir os espécimes que atendessem suas demandas científicas e expositivas, como também se inserir num circuito internacional de trocas que envolvia diversos museus, pesquisadores, casas comerciais, fornecedores de equipamentos e caçadores.

Inicialmente, tentaremos entender porque a compra foi utilizada como estratégia para aquisição de espécimes científicos pelo Museu Paulista. Em seguida, trataremos da existência de comerciantes residentes no país e, depois disso, abordaremos a questão das relações comerciais com negociantes estrangeiros. Por fim, discorreremos sobre a atuação do Museu Paulista no âmbito dessa rede de comércio, com particular atenção para o caso das relações mantidas entre Ihering e o caçador Ferdinand Schwanda.

\subsection{Coletar, permutar, comprar}

A formação de coleções nos museus de História Natural estava sujeita a uma série de particularidades e vicissitudes - ligadas tanto aos interesses científicos quanto às possibilidades ou restrições para a obtenção de amostras da natureza.

No caso do Museu Paulista, a reunião de coleções encontrava uma série de dificuldades para se realizar a contento. Tratando-se de uma instituição que pretendia dar conta da História Natural brasileira - e por vezes sul-americana -, fazia-se necessário percorrer um território extremamente vasto em busca de animais, plantas, minerais, fósseis, artefatos arqueológicos e etnológicos. ${ }^{44}$ Percorrer esse amplo território dependia, primeiramente, da capacidade de ter acesso a áreas distantes e pouco servidas de estradas e infraestrutura urbana. Além

outros tinham uma política de compras agressiva, enquanto outros coletavam por meio de seu próprio estafe. Os diferentes propósitos desses museus (alguns pretendiam reunir apenas coleções locais, outros almejavam ser universais), bem como as diferenças de orçamento, influíam na definição das estratégias de aquisição. Ver SHEETS-PYENSON, Susan. Cathedrals of science: the development of colonial Natural History museums during the late nineteenth century. Montreal: McGill-Queen's University Press, 1988, pp. 69-91.

${ }^{44}$ Ver nota 42 acima. 
disso, era necessário enviar (ou trazer) para o museu os materiais coletados, o que também poderia se mostrar tarefa difícil dependendo do volume de material.

Não bastassem essas dificuldades, a instituição tinha que lidar ainda com um agravante: seu pequeno quadro funcional. A coleta de espécimes se tornava difícil para um estabelecimento que contava, na maior parte do tempo, tão somente com um único empregado encarregado disso, um naturalista viajante - embora, eventualmente, outros funcionários (como o preparador) também se dedicassem a coletar material. ${ }^{45}$

Somando-se à vastidão da área a ser coberta e ao pequeno quadro funcional, havia os riscos envolvidos na exploração de territórios inóspitos. Além dos perigos das doenças tropicais, o contato com as populações indígenas nem sempre era amistoso. Testemunho disso é o episódio envolvendo Curt Unkel, etnólogo alemão contratado pelo Museu para ir aos "Campos Novos do Paranapanema" com o objetivo de procurar os índios Chavantes. ${ }^{46}$ Conforme indica Ernesto Garbe em correspondência ao diretor do Museu, Unkel acabaria sendo pilhado pelos índios, ficando até mesmo sem sua arma e sem dinheiro para prosseguir viagem. ${ }^{47}$

Questões econômicas também deveriam contribuir para tornar a coleta direta algo no mínimo difícil. Enviar uma expedição a um local distante deveria ser algo bastante custoso. Em ofício ao Secretário do Interior, datado de 1908, o diretor do

\footnotetext{
${ }^{45}$ Inicialmente, o quadro de funcionários do Museu contava com seis cargos: diretor; zelador ou custos (curador - ver a nota 48 à frente); naturalista viajante; preparador; amanuense; e contínuoservente. Com o passar dos anos, Ihering conseguiu, em alguns momentos, ampliar o número de funcionários, contratando um porteiro, alguns serventes, um preparador auxiliar, um entomologista, um preparador auxiliar de Entomologia, um desenhista, um tradutor, um jardineiro e auxiliares de jardinagem. Muitas vezes, tais funcionários extras eram pagos com a verba de expediente do Museu. Ver LOPES, Maria Margaret, op. cit., 1997, pp. 270-271; OfícIO do diretor interino do Museu Paulista ao Secretário do Interior, com lista de funcionários do Museu anexa, São Paulo, 21/07/1916. Arquivo Permanente do Museu Paulista/Fundo Museu Paulista (APMP/FMP), Dossiê Comissão de Sindicância sobre a gestão de Hermann von Ihering. Ver adiante a lista de funcionários técnicocientíficos do Museu Paulista (Apêndice B). Cabe ressalvar que a situação do Museu Paulista, com seu quadro funcional diminuto, não devia diferir daquela da maior parte dos museus situados fora das grandes capitais europeias. Ver SHEETS-PYENSON, Susan, op. cit., 1988, pp. 37-39.

${ }^{46}$ Curt Unkel (1883-1945) foi um etnólogo alemão que veio para o Brasil em 1903. Em São Paulo, estudou índios guaranis e caingangues. Em 1913 se mudou para o Pará, onde passou a estudar etnias amazônicas. Suas viagens etnográficas resultaram ainda no envio de coleções para museus europeus e brasileiros. Ver BALDUS, Herbert. Curt Nimuendajú. Boletim Bibliográfico, 2, 7, pp. 91-99.

${ }^{47}$ CARTA em alemão, com tradução anexa, de Ernesto Garbe a Hermann von Ihering, Serra Macaé, Estado do Rio, 12/11/1909. APMP/FMP, Série Correspondência. Cerca de $40 \%$ da correspondência em alemão existente na Série conta com traduções para o português, de autoria desconhecida, armazenadas junto aos documentos originais. Nesses casos, os trechos reproduzidos serão extraídos das traduções. Utilizamos a expressão "tradução anexa" para indicar a existência de tal tradução.
} 
Museu argumenta que era mais vantajoso comprar os espécimes enviados por um coletor residente no Maranhão, Ferdinand Schwanda, do que enviar o naturalista viajante do Museu àquela região. ${ }^{48}$

Para dar conta desse território imenso com um quadro funcional tão reduzido, e para ultrapassar esses obstáculos operacionais, foi necessário, portanto, lançar mão de uma alternativa: comprar espécimes. O Museu Paulista se utilizou largamente desse expediente, seja adquirindo espécimes de coletores residentes no Brasil, seja de casas especializadas sediadas na Europa e, em escala bem menor, nos Estados Unidos.

Certamente, mesmo com todas as dificuldades a que nos referimos, o volume de espécimes obtido pelo quadro de funcionários do próprio Museu superava em muito o material adquirido por meio de compra. Os números relativos à coleção ornitológica nos dão uma noção nesse sentido. ${ }^{49}$ Dos 8.051 espécimes efetivamente registrados no livro de tombo de aves até 1916, quase $60 \%$ foram adquiridos por coletas realizadas pelo próprio estafe do Museu, enquanto pouco mais de $20 \%$ foi obtido por meio de compra - o restante dividindo-se entre aquisições por permuta, doação e formas não identificadas (ver o Apêndice A). ${ }^{50}$

A aquisição de espécimes por meio de compra deve ser entendida, portanto, como uma estratégia para complementar as coleções, pois possibilitava adquirir espécimes faltantes no acervo do Museu, bem como aqueles de regiões não exploradas pelo estafe da instituição.

A permuta de espécimes com instituições congêneres ou mesmo colecionadores particulares, bem como as doações, também eram mecanismos de aquisição empregados pelo Museu para complementar o trabalho de coleta direta. Todavia, a compra de espécimes parece ter sido um modo particularmente importante de incremento das coleções, uma vez que adquirir materiais por doação e permuta dependia da disponibilidade de duplicatas nas instituições congêneres e dos interesses de colecionadores privados. Tanto é assim que, ao menos no caso

\footnotetext{
${ }^{48}$ OfícIO [de Hermann von Ihering] ao Secretário do Interior, São Paulo, 29/10/1908. APMP/FMP, Série Correspondência. Sobre Schwanda, ver o item 1.5 e o Apêndice $C$ desta dissertação.

${ }^{49}$ Devido ao volume de dados que seria necessário tabular, não foi possível contabilizar, para todos os grupos animais, a proporção de compras em relação ao total de espécimes adquiridos.

50 MUSEU Paulista: Catálogo Accessional: Aves. Tomos 1 e 2. Acervo da Seção de Ornitologia do Museu de Zoologia da USP.
} 
das aves, o volume de material que ingressou por permuta e doação é relativamente diminuto: $6,8 \%$ foram adquiridos por permuta e $0,8 \%$ por doação.

Conforme o próprio Ihering, as permutas mantidas com colecionadores brasileiros eram poucas:

\begin{abstract}
De entre os particulares com os quais aqui no país possamos manter relações de permuta, bem poucos há e estes, quase todos são colecionadores de borboletas. Mencionaremos a este respeito os distintos cavalheiros Srs. E. May e Julius Arp, ambos do Rio de Janeiro, com os quais temos permutado com bom proveito para as nossas coleções. É muito natural que tais amadores escolham de preferência um grupo de animais atraentes pela beleza das cores e elegância das formas; deste modo também são os lepidópteros diurnos um dos grupos mais bem estudados da nossa fauna. Fazemos votos, porém, para que sucessivamente se vá despertando entre esses nossos auxiliares amadores, o gosto pela coleção de outros insetos, talvez menos lindos, mas igualmente atraentes, principalmente pelo interesse que desperta o estudo da sua ecologia. ${ }^{51}$
\end{abstract}

A compra, portanto, diferentemente da permuta e das doações, ensejava melhores oportunidades para o Museu escolher os materiais que atendessem às suas necessidades científicas e expositivas. Afinal, a coleta pelo próprio estafe do Museu, como vimos, enfrentava uma série de obstáculos, os quais impediam que ela suprisse sozinha a demanda da instituição por espécimes.

Mas para que essa vantagem da compra sobre a doação e a permuta se efetivasse, era necessária a existência de uma boa oferta de espécimes à venda. Nesse sentido, será interessante observar a estratégia adotada por Ihering com a finalidade de fomentar o comércio de produtos de História Natural no país. O diretor procurava conectar caçadores residentes no país a revendedores estrangeiros, constituindo assim uma rede de relações comerciais capaz de garantir a existência de coletores atuantes no Brasil dos quais o Museu pudesse adquirir espécimes.

Antes de tratar dessa estratégia de lhering, todavia, será necessário examinar o funcionamento desse comércio de espécimes no Brasil e no exterior, com atenção para os fornecedores do Museu Paulista.

\footnotetext{
${ }^{51}$ [IHERING, Hermann von]. O Museu Paulista nos annos de 1910, 1911 e 1912. Revista do Museu Paulista, 9, 1914, p. 22.
} 


\subsection{Caçadores no Brasil}

Em carta datada de 1906, o pesquisador francês Henry Brölemann pergunta a Rodolpho von Ihering, filho do diretor e zelador ${ }^{52}$ do Museu Paulista, sobre a existência de vendedores de insetos no Brasil: "Connaissez-vous des personnes qui fassent métier de chasser des insectes et qui pouvaient recueillir des orthoptères edes (sic) hémiptères et vendre leurs chasses?"53

Infelizmente, não sabemos a resposta que foi dada ao cientista francês. Todavia, é provável que tenha sido positiva, uma vez que o próprio Museu Paulista servia-se, como veremos, dos serviços de caçadores atuantes no país. Mas a dimensão que possuía esse comércio de espécimes no Brasil ainda não é bem conhecida.

Lopes, baseada em dados do missionário norte-americano Daniel Kidder - o qual aponta que os valores envolvidos na exportação de produtos de História Natural do Rio de Janeiro em 1841/42 eram maiores do que os de gêneros como feijão, algodão e cacau -, indica que a exportação de produtos de História Natural brasileiros deve ter tido importância considerável em meados do século XIX. ${ }^{54}$

Duarte tratou do comércio de penas de aves brasileiras e do aparecimento dos primeiros discursos apontando o perigo dessa atividade para a avifauna nacional. Segundo a autora, o Brasil exportou, entre 1901 e 1905, uma soma de cerca de 600 quilos de penas, e, entre 1910 e 1914, um total de 20 mil quilos. A

\footnotetext{
${ }^{52} \mathrm{O}$ cargo de zelador ou custos, de acordo com o Regulamento do Museu, deveria ser ocupado por "(...) um zoologista formado em uma universidade ou academia de ciências naturais, com tirocínio prático, preferindo-se o que for autor de trabalhos técnicos e minuciosos em zoologia e botânica ou tiver servido como ajudante em museu científico." Ainda segundo o Regulamento, o zelador seria o ajudante científico do diretor, encarregado da conservação das coleções, da organização dos catálogos e da realização dos estudos científicos indicados pelo diretor. Caberia ainda ao zelador substituir o diretor quando esse estivesse ausente. Ver o Decreto n. 249, de 26 de julho de 1894. O termo "custos" é uma adaptação da palavra alemã Kustos (plural, Kustoden), que pode ser traduzida como "curador" ou "conservador". Grandes museus alemães possuíam vários Kustoden, como o Museum für Naturkunde de Berlim, com seus oito curadores. Ver KöSTERING, Susanne, op. cit., 2003, p. 41.

CARTA de Henry Brölemann a Hermann von Ihering, Cannes, 27/02/1906. APMP/FMP, Série Correspondência.

${ }^{54}$ A autora também faz referência: à atuação dos chamados "negros naturalistas"; à compra de algumas coleções pelo Museu Nacional, como um conjunto de animais adquirido de Antônio Manuel Lobo Peçanha, que antes seria exibido na Exposição de Viena de 1873; e ao naturalista francês João Teodoro Descourtilz, que esteve estabelecido com negócio de produtos de História Natural no Rio de Janeiro em meados do séc. XIX, tendo inclusive vendido coleções ao Museu Nacional. LOPES, Maria Margaret, op. cit., 1997, p. 98, nota 26, p. 104 e p. 128.
} 
autora se refere ainda a um comércio de couros de pássaros, indicando que, no Rio de Janeiro, uma só fazenda exportava por ano 20 mil couros de beija-flores para a França. Todavia, a questão do comércio de animais para fins científicos está fora do horizonte de interesse de Duarte. ${ }^{55}$

Embora alguns autores já tenham, como vemos, feito referência ao tema, não temos ainda muitas informações sobre a extensão e o funcionamento desse comércio. Mas algumas fontes dão pistas sobre o assunto.

Gottfried Hagmann (1874-1946), responsável pelo Jardim Zoológico do Museu Paraense Emílio Goeldi entre 1899 e 1904, trata das atividades de comerciantes de animais vivos em Belém, dos quais o Museu adquiria animais silvestres para seu Jardim. No entanto, o zoólogo afirma que se tratava de atividade incipiente e pouco profissionalizada, o que, inclusive, dificultava o estabelecimento de contatos entre esses negociantes e revendedores europeus. $O$ autor afirma ainda que as avultadas despesas com transporte dificultavam o comércio de animais entre o norte e o sul do Brasil. ${ }^{56}$

Esse quadro pintado para os animais vivos não devia equivaler totalmente ao dos animais mortos (ou fragmentos deles) destinados a coleções. Temos, nas revistas agrícolas $O$ Entomologista Brasileiro e Chacaras e Quintaes, anúncios de estrangeiros - colecionadores e revendedores de insetos - interessados em fazer negócios do lado de cá do Atlântico. Por exemplo, um anúncio de Carl Zacher, de Berlim, demanda, para compra, borboletas da América do Sul. ${ }^{57}$

Outro anúncio, bem menos modesto, é o do revendedor de espécimes francês E. Le Moult (figura 1). A propaganda de página inteira, com direito ao desenho de um enorme besouro vermelho, aparece em português em volume da

\footnotetext{
${ }^{55}$ Ver DuARTE, Regina Horta. Pássaros e cientistas no Brasil: Em busca de proteção, 1894-1938. Latin American Research Review, 41, 1, 2006, pp. 3-26.

${ }^{56}$ SANJAD, Nelson et al., op. cit., 2012, pp. 212-219.

${ }^{57}$ ANúNClO de Carl Zacher. O Entomologista Brasileiro, ano 2, 2, 10-11, 01/02/1909. As revistas O Entomologista Brasileiro e Chacaras e Quintaes foram empreendimentos criados pelo conde italiano Amadeu Barbiellini (que desembarcou no Brasil em 1907). Sobre essas revistas e o contexto do periodismo e das questões agrícolas da época, ver MARTINS, Ana Luiza. Revistas em revista: imprensa e práticas culturais em tempos de República, São Paulo (1890-1922). São Paulo: Edusp/Fapesp/Imprensa Oficial do Estado, 2001, p. 280 e pp. 282-303; e WELTMAN, Wanda Latmann. A educação do Jeca: ciência, divulgação científica e agropecuária na Revista Chácaras e Quintais (1909-1948). Rio de Janeiro, 2008. Tese (Doutorado) - Casa de Oswaldo Cruz, Fundação Oswaldo Cruz.
} 
Chacaras e Quintaes do ano de 1910. Além de "Grande variedade de coleções de insetos de todas as ordens e de todos os países", oferece-se largo sortimento de alfinetes e demais equipamentos para coleções entomológicas. O negociante também se prontifica a adquirir insetos de coletores atuantes no Brasil: "Compras e permutas ao mais alto preço aos missionários, funcionários, soldados e colonos"; "Compra e permuta em grande escala os insetos de todas as ordens do Brasil e outros países sul-americanos. ${ }^{.58}$

Outra fonte que aponta a existência de avultado comércio de espécimes é uma passagem da introdução de um catálogo elaborado por Ihering e seu filho:

Do Estado da Bahia anualmente milhares de couros de aves são enviados à Europa e em especial a Londres, onde são vendidos em leilão. Os ornitólogos europeus julgam, por este motivo, a ornitologia baiana bem conhecida, o que, porém, é um engano. Todos esses couros provêm de uma zona limitada e tanto o Sul como o Oeste do Estado da Bahia são quase desconhecidos em relação à sua avifauna. ${ }^{59}$

No caso da América Latina, Podgorny examinou o envolvimento de eruditos, na primeira metade do século XIX, no comércio de manuscritos e ossos fósseis provenientes do território do antigo vice-reinado do Rio da Prata. ${ }^{60}$

Como vemos, no caso do Brasil e da América Latina, ainda carecemos de informações que permitam caracterizar e dimensionar o comércio de espécimes zoológicos. No entanto, a julgar pelo caso dos Estados Unidos, diríamos que o papel dos negociantes de espécimes deve ter tido importância considerável para a formação das coleções científicas. De acordo com Barrow, durante a segunda metade do século XIX, naturalistas europeus e americanos frequentemente exerciam atividades comerciais ligadas à História Natural. O que, em alguns casos, era apenas um meio temporário ou esporádico de obter algum dinheiro, em outros se tornava um empreendimento mais sistemático e de longo prazo. Segundo o

\footnotetext{
${ }^{58}$ ANúNCIO de E. Le Moult. Chacaras e Quintaes, 2, 1, jul. 1910, contracapa. Como veremos, alguns anos mais tarde Le Moult também ofereceria seus insetos ao Museu Paulista.

59 IHERING, Hermann von; IHERING, Rodolpho von. As aves do Brasil. São Paulo: Typographia do Diario Official, 1907 (Catalogos da Fauna Brazileira, 1), p. VI.

${ }^{60}$ PODGORNY, Irina. Mercaderes del pasado: Teodoro Vilardebó, Pedro de Angelis y el comercio de huesos y documentos en el Río de la Plata, 1830-1850. Circumscribere: International Journal for the History of Science, 9, 2011, pp. 29-77.
} 
autor, no final do século XIX, mais de uma centena de negociantes de espécimes estavam em atuação nos EUA.

Barrow examina mais detidamente quatro grandes estabelecimentos comerciais dedicados à venda de espécimes - como o Ward's Natural Science Establishment, que por volta de 1880 possuía 15 prédios e 22 funcionários. Conforme esse autor, tais empreendimentos teriam desempenhado papel fundamental na grande expansão dos museus americanos de História Natural ocorrida nas três últimas décadas do século XIX, já que tais empresas foram responsáveis por abastecer esses museus com grande número de espécimes.

Essas grandes casas comerciais trabalhavam com amplas redes de coletores, além de patrocinarem expedições de vulto. Vendiam tanto para indivíduos e instituições de ensino quanto para grandes museus. Além de anunciarem em periódicos de História Natural, as empresas distribuíam catálogos e chegavam, em alguns casos, a editar seus próprios periódicos. ${ }^{61}$

$\mathrm{Na}$ Europa, esse comércio de produtos de História Natural também apresentava, por vezes, amplas dimensões. Em artigo da Chacaras e Quintaes, Amadeu Barbiellini (proprietário da revista) aponta, talvez com algum exagero, a grandiosidade do mercado europeu de lepidópteros e, na expectativa de que brasileiros pudessem lucrar com ele, instrui sobre como criar, para venda, tais insetos em cativeiro. ${ }^{62}$

Segundo Barbiellini, o mercado mundial de borboletas para coleção havia movimentado, nos 50 anos anteriores (o artigo é de 1910), cerca de 1 bilhão de dólares. O autor apresenta outros números grandiosos: 20 milhões de francos seria a soma anual envolvida no comércio de borboletas; 20 mil francos foi o valor pago por um único exemplar num leilão ocorrido pouco tempo antes em Londres; 1.000

\footnotetext{
${ }^{61}$ BARROW, Mark V. The Specimen Dealer: Entrepreneurial Natural History in America's Gilded Age. Journal of the History of Biology, 33, 3, 2000, pp. 493-534.

${ }^{62} \mathrm{O}$ conde Amadeu Barbiellini era amante da Entomologia. Além de possuir coleções próprias, era sócio da Royal Entomological Society e mantinha contato com entomologistas. Ver WELTMAN, Wanda Latmann, op. cit., 2008, p. 86.
} 
dólares seria o mais alto valor já pago por um único exemplar (um espécime venezuelano comprado pelo colecionador Walter Rotschild). ${ }^{63}$

Ainda segundo Barbiellini, Londres seria o principal mercado do comércio de borboletas, realizando-se anualmente cinco ou seis leilões, dos quais participavam colecionadores e naturalistas. Na Alemanha, o comércio de borboletas também era bastante volumoso:

Outros centros comerciais existem na Alemanha que é a pátria clássica da entomologia. Neste país, porém, o comércio das borboletas tem uma base puramente científica e o Staudinger de Blasevitz era até pouco tempo $o$ verdadeiro rei das borboletas. Este notável lepidopterologista possuía a mais completa coleção particular de borboletas e pela sua morte o governo da Prússia a adquiriu por soma espantosa. A sua casa que existe ainda sob a firma Staudinger \& Haas é a mais colossal e todos os museus do mundo têm relações com este empório de borboletas que manda emissários às regiões mais distantes e mais inacessíveis, à caça das aladas vagabundas dos campos, bosques e jardins.

Para se julgar a importância dessa casa, diremos que a firma, fundada por Staudinger, publica todos os anos o catálogo das suas borboletas com os respectivos preços, onde elas são apenas enumeradas com o seu nome científico, no corpo tipográfico mais diminuto, o que significa que em cada página são citados diversos milhares de borboletas diferentes. No entanto este catálogo constitui um grosso volume de muitas centenas de páginas! [4 $^{4}$

Além do alemão Staudinger citado por Barbiellini, existiram diversos outros negociantes de espécimes científicos no continente europeu. Reiling e Spunarová tratam de um desses negociantes, o tcheco Václav Frič (1839-1916). Sua loja em Praga comercializava, além de espécimes, objetos para auxiliar o ensino de ciências naturais - aliás, como faziam várias outras empresas do gênero. Além de vender para instituições tchecas, o negociante exportava produtos para clientes de outros países europeus. ${ }^{65}$

$\mathrm{Na}$ Alemanha Imperial (1871-1918), apenas em Berlim existiam 52 negociantes de objetos de História Natural. Muitas das empresas alemãs envolvidas

\footnotetext{
${ }^{63}$ BARBieluinI, Amadeu A. A caça e a criação de mariposas é um negócio lucrativo. Chacaras e Quintaes, 2, 5, nov. 1910, pp. 23-24.

64 Ibidem, p. 24.

65 ReILING, Henri; SpunarovÁ, Tat'jána. Václav Frič (1839-1916) and his influence on collecting natural history. Journal of the History of Collections, 17, 1, 2005, pp. 23-43.
} 
nesse ramo de negócios comercializavam principalmente materiais didáticos para museus e escolas - por exemplo, preparações destinadas a mostrar as fases do desenvolvimento de insetos ou anfíbios -, embora também lidassem com espécimes para coleções científicas. ${ }^{66}$ Segundo Köstering, as empresas de materiais didáticos alemãs sofreram um processo de concentração durante o período imperial: dos 142 empreendimentos existentes em 1872, só 20 ou 30 grandes casas restaram na virada para o século XX. Entre os empreendimentos reputados pela autora como os mais conhecidos no ramo de materiais didáticos, estavam firmas também atuantes no ramo do comércio de espécimes, inclusive algumas com as quais - como veremos - o Museu Paulista manteve relações comerciais: Schlüter, Krantz e Staudinger \& Bang-Haas. ${ }^{67}$

No caso do Museu Paulista, a documentação preservada no arquivo da instituição indica que ela se utilizava largamente do serviço de negociantes de espécimes atuantes no Brasil.

Por exemplo, em 1897, o Museu gasta uma soma considerável com a compra de espécimes amazônicos. Em ofício ao Secretário do Interior, Ihering informa que havia adquirido "(...) objetos amazonenses pertencentes ao Sr. Antônio Carneiro de M. Leão, que ultimamente havia exposto na Rua 15, pelo preço de 3:500\$000". Anexo ao ofício, encontramos a lista com mais de 34 espécimes animais (mamíferos, peixes, répteis e aves), designados por seus nomes vulgares e respectivos preços. ${ }^{68}$

Embora pouco se saiba sobre a maior parte desses negociantes que atuavam no Brasil, documentos existentes no arquivo do Museu Paulista, como recibos de compra, registros em livros de aquisição e cartas trocadas com o diretor do Museu, indicam-nos ao menos nomes de indivíduos que teriam coletado para vender à instituição. Figuras como: Otto Dreher, Ernesto Garbe, Mathias Wacket, Francisco Günther, Ricardo Krone, Christiano Enslen, Hellmuth Pinder, Adolph Hempel,

\footnotetext{
${ }^{66}$ KöSTERING, Susanne, op. cit., 2003, p. 20.

${ }^{67}$ Ibidem, pp. 193-197.

${ }^{68}$ OfícIo [de Hermann von Ihering] ao Secretário do Interior, São Paulo, 04/03/1897. APMP/FMP, Série Correspondência.
} 
Ferdinand Schwanda, entre outros. O Apêndice C apresenta uma listagem dos coletores atuantes no Brasil que venderam espécimes para o Museu Paulista.

Ricardo Krone (1861-1917), por exemplo, natural de Dresden, Alemanha, veio para o Brasil em 1884, após concluir seus estudos de engenheiro geógrafo em sua terra natal. Aqui, trabalhou inicialmente como engenheiro e agrimensor. Mais tarde, residindo em Iguape, onde também trabalhava como farmacêutico, Krone atuou como fornecedor de espécimes para diversos museus do mundo. ${ }^{69}$ Para o Museu Paulista, enviou diversas remessas - por exemplo, uma de 200 ovos de pássaros, peixes e outros objetos $(130 \$ 000)^{70}$ e uma consistindo em couros, ovos e ninhos de pássaros $(466 \$ 720){ }^{71}$

Alguns desses indivíduos chegaram a ser funcionários do Museu em algum momento de suas trajetórias, como Adolph Hempel, Hellmuth Pinder e Ernesto Garbe - esse último passou a ocupar em 1902 o cargo de naturalista viajante ${ }^{72}$ mas antes disso vendeu espécimes para a instituição.

Todavia, o que nos parece mais interessante, quanto aos coletores atuantes no Brasil, é notar que, em alguns casos, esse comércio já apresentava algum grau de organização ou profissionalização. Algumas correspondências emitidas por esses coletores nacionais são redigidas em papeis timbrados que propagandeiam seus empreendimentos. Uma conta de Hellmuth Pinder, de 1905, referente a uma coleção de aves e ovos (54\$50), vai em papel com a seguinte impressão: "Hellmuth Pinder - Oficina de bandagens - Ateliê de embalsamador de animais - Rua do Triunfo, 27, [São Paulo]". ${ }^{73}$

Hellmuth Pinder (1874-1918) nasceu em Kassel, Alemanha. Veio para o Brasil em 1895 e no ano seguinte passou a ocupar o cargo de preparador do Museu Paulista. Segundo Camargo, Pinder deve ter deixado seu emprego no Museu no final do ano de 1900 para atuar como comerciante de peles de aves. Morou em São Sebastião e em Santos, tendo ocupado, nos anos finais de sua vida, o cargo de

\footnotetext{
${ }^{69}$ ANÔNIMO. Ricardo Krone. Revista do Museu Paulista, 10, 1918b, pp. 929-938

${ }^{70}$ CONTA de Ricardo Krone, São Paulo, 01/01/1895. APMP/FMP, Série Prestação de contas.

${ }^{71}$ CONTA de Ricardo Krone, Iguape, 15/09/1898. APMP/FMP, Série Prestação de contas.

72 IHERING, Hermann von. O Museu Paulista em 1901 e 1902. Revista do Museu Paulista, 6, 1904, p. 4.

${ }^{73}$ RECIBO de Hellmuth Pinder, São Paulo, 30/04/1905. APMP/FMP, Série Prestação de contas.
} 
oficial aduaneiro na Alfândega de Santos. ${ }^{74}$ Todavia, continuou a manter relações com o Museu mesmo nessa condição, conforme atestam cartas trocadas com Ihering tratando da venda de espécimes em 1914 e $1916 .{ }^{75}$ Pinder chegou a avaliar junto ao diretor, em 1912, a possibilidade de voltar a ocupar o cargo de preparador do Museu. ${ }^{76}$

Sobre a atuação de seu empreendimento de História Natural em São Paulo, nos anos iniciais do século XX, existem ainda informações contidas em duas edições do jornal $O$ Estado de S. Paulo. Na primeira, de 1905, há um anúncio que divulga a instalação, na Rua São João, n. 105-B, em frente ao Largo do Paissandu, das oficinas de Faerder \& Pinder. A empresa, além de se dedicar à fabricação de instrumentos de cirurgia e ortopedia, e de oferecer serviços de afiação de facas, navalhas e tesouras, preparava e comercializava produtos de História Natural. De acordo com o anúncio:

Junto com as oficinas mecânicas temos estabelecido uma seção para a conservação de objetos naturais, e fornecemos também coleções inteiras para o uso científico de faculdades clínicas, colégios, escolas e particulares. $\mathrm{Na}$ nossa casa é sempre encontrado um grande sortimento de pássaros embalsamados e ovos de muitas espécies, e também retratos de indígenas do Brasil.

Surram-se e preparam-se peles para uso científico e para ornamentação, como para servir de tapetes, etc., sendo feito todo o serviço desta seção pelo sócio sr. Pinder, ex-preparador de diversas faculdades alemãs. ${ }^{77}$

No ano seguinte, o Estado traz a informação de que Pinder saía em expedição ao Mato Grosso comissionado por diversos museus estrangeiros:

Em serviço de exploração científica pelos sertões de Mato Grosso, partem por estes dias desta capital os srs. dr. H. Pinder e Antonio Pereira Ventura, que vão comissionados por vários museus estrangeiros.

\footnotetext{
${ }^{74}$ Camargo, Hélio F. de Almeida. Hellmuth Pinder, o primeiro coletor e taxidermista de aves do Museu Paulista. Ararajuba, 6, 1, 1998, pp. 54-57.

${ }^{75}$ CARTA de Hellmuth Pinder [a Hermann von Ihering], Santos, 14/02/1914. APMP/FMP, Série Correspondência; e CARTA [de Hermann von Ihering] a Hellmuth Pinder, São Paulo, 15/03/1916. APMP/FMP, Série Correspondência.

${ }^{76}$ CARTA em alemão, com tradução anexa, de Hellmuth Pinder a Hermann von Ihering, Santos, 18/02/1912. APMP/FMP, Série Correspondência.

${ }^{77}$ ANúNCIO de Faerder \& Pinder. O Estado de S. Paulo, 18/10/1905, p. 3.
} 
O intuito principal da viagem é o estudo das espécies zoológicas, existentes naquela região do Brasil, muitas das quais são até agora pouco conhecidas. $^{78}$

Outro caso de coletor que desempenhava a atividade de modo formal é o de Otto Dreher. Residente no interior de São Paulo, Dreher, que figurava recorrentemente como fornecedor de espécimes ao Museu Paulista, também utilizava para suas correspondências papel de carta próprio, cujo cabeçalho impresso apresentava suas especialidades:

Otto Dreher - Naturalista - Preparação anatômica de ossos e esqueletos
para estudo das escolas médicas - Preparação artística de cabeças de
animais - pelos para tapetes - Animais inteiros, Pássaros, Répteis, Felinos,
Anfíbios, etc., etc. - Aceita encomendas para coleções de Borboletas,
Besouros, Ovos de pássaros e Jacarés, Cágados, Pedras, etc. etc. - São
Paulo (Brasil). ${ }^{79}$

O papel de carta de Dreher, assim como o anúncio de Pinder n'O Estado de S. Paulo, indica que tal comércio poderia atender, além dos museus de História Natural, instituições de ensino, colecionadores privados, e mesmo caçadores que quisessem empalhar seus troféus ou pessoas interessadas em adquirir animais empalhados para fins decorativos. ${ }^{80}$

A carta referida acima é de 1906. Antes disso, em 1903, Dreher chegou a utilizar papel timbrado indicando que executava trabalhos para o Museu Paulista: "Otto Dreher - Naturalista e colecionador - Museu Paulista - São Paulo (Brasil)". ${ }^{81}$ Dreher não pertenceu ao quadro funcional oficial do Museu, mas talvez tivesse entrado em algum entendimento com lhering no sentido de realizar expedição para região de interesse da instituição e lhe fornecer regularmente espécimes. Afinal, em 1902, Ihering redige ofício ao presidente da câmara municipal de Franca

\footnotetext{
${ }_{78}^{78}$ NOTAS e informações. O Estado de S. Paulo, 26/05/1906, p. 1.

${ }^{79}$ CARTA, em alemão, de Otto Dreher a Hermann von Ihering, Bauru, 22/10/1906. APMP/FMP, Série Correspondência. O cabeçalho citado está originalmente redigido em português.

${ }^{80}$ Pressupomos, tendo em vista as ofertas de serviços dos dois caçadores, que o uso de peles e chifres de animais como elementos de decoração, agregados ou não a peças de mobiliário, deveria ser algo relativamente comum na São Paulo daquele período. Seria necessário, todavia, dispor de mais dados que pudessem confirmar ou não tal pressuposto, o que se situa fora da circunscrição deste trabalho.

${ }^{81}$ CONTA de Otto Dreher, Franca, 19/08/1903. APMP/FMP, Série Prestação de contas.
} 
apresentando Otto Dreher, o qual, segundo a carta, era enviado pelo Museu com o objetivo de explorar aquela região do estado. ${ }^{82}$

Além disso, é justamente de meados de 1902 a meados de 1903 que se concentra a maior parte das remessas de Dreher, provenientes justamente de Franca. Mais tarde, em 1904, temos outro papel timbrado com a indicação: "Otto Dreher - Naturalista - Ponte Ipê Arcado - Estado Goiás". ${ }^{83}$ Ou seja, após ter ido em expedição à região de Franca com a finalidade de coletar material para vender ao Museu Paulista, Dreher parece ter ampliado sua clientela e passado a coletar também em outras regiões.

Adolph Hempel era outro indivíduo residente no Brasil que atuava no comércio de espécimes. Nascido nos Estados Unidos, Hempel também foi, durante algum tempo, funcionário do Museu Paulista - ocupou, seguidamente, os cargos de entomologista e zelador, tendo deixado a instituição no ano de $1900 .^{84}$ Durante vários anos, provavelmente após sua saída do Museu, vendeu espécimes para a instituição. Uma carta emitida por ele encontrada no arquivo do Museu Paulista é redigida em papel próprio, o qual apresenta a seguinte impressão no cabeçalho: "Adolph Hempel - Dealer in Natural History specimens from Brazil - Caixa n. 7 State of São Paulo [Campinas] - Orders taken and special collections made for work in morphology, etc." 85 O texto em inglês sugere que Hempel devia exportar espécimes brasileiros para colecionadores estrangeiros, possivelmente para aqueles dos Estados Unidos, sua terra natal.

Outro documento que traz informação interessante sobre atividades comerciais em São Paulo envolvendo materiais científicos é uma carta de loja

\footnotetext{
${ }^{82}$ Ofícıo [de Hermann von lhering] ao Presidente da Câmara Municipal de Franca, São Paulo, 25/06/1902. APMP/FMP, Série Correspondência.

${ }^{83}$ CARTA, em alemão, de Otto Dreher a Hermann von Ihering, Araguari, 10/07/1904. APMP/FMP, Série Prestação de contas. O cabeçalho citado está originalmente em português.

${ }^{84}$ Ver StRAuBE, Fernando C.; WILLIS, Edwin O.; ONIKI, Yoshika. Aves colecionadas na localidade de Fazenda Caiuá (Paraná, Brasil) por Adolph Hempel, com discussão sobre a sua localização exata. Ararajuba, 10, 2, 2002, p. 167. Cf. também IHERING, Hermann von. O Museu Paulista em 1899 e 1900. Revista do Museu Paulista, 5, 1892, p. 2.

${ }^{85}$ CARTA de Adolph Hempel a Hermann von Ihering, Campinas, 15/05/1908. APMP/FMP, Série Prestação de contas.
} 
chamada Casa de Utensílios Científicos. Na correspondência, o emissor oferece tábuas impregnadas de naftalina, importadas do Japão, para conservar borboletas. ${ }^{86}$

\subsection{Negociantes na Europa}

Mas nem só do serviço desses negociantes nacionais se utilizava o Museu Paulista. A documentação existente no arquivo da instituição indica que eram comprados espécimes também de casas estrangeiras. ${ }^{87}$ Adquiriam-se espécimes comercializados por vários negociantes europeus, além de um sediado nos EUA, justamente o Ward's Natural Science Establishment, a grande empresa americana à qual nos referimos anteriormente. A maioria das encomendas vinha de negociantes alemães: Hermann Rolle e seu "Kosmos - Naturhistorisches Institut"; Wilhelm Schlüter; Otto Staudinger e seu sócio Andreas Bang-Haas; além de J. F. G. Umlauff e Friedrich Krantz. Muitas relações também foram travadas com a casa londrina de William Frederick Henry Rosenberg. O museu adquiria ainda, em menor escala, material científico de diversos outros negociantes europeus. No Apêndice D, listamos as quinze casas comerciais estrangeiras com as quais o Museu estabeleceu algum tipo de contato durante a gestão de Ihering. ${ }^{88}$

É difícil contabilizar com precisão o comércio de espécimes mantido entre esses fornecedores e o Museu, pois: os recibos nem sempre discriminam o conteúdo da aquisição; nem só espécimes eram adquiridos, mas também

\footnotetext{
${ }^{86}$ CARTA de Beto Moser, Casa de Utensílios Científicos, a Hermann von Ihering, São Paulo, 01/05/1915. APMP/FMP, Série Correspondência.

${ }^{87}$ Lopes já havia indicado que o Museu havia comprado coleções dos negociantes alemães Rolle e Krantz. Ver LOPES, Maria Margaret, op. cit., 1997, p. 275. Recorrer a revendedores de espécimes sediados nas grandes cidades europeias não era procedimento exclusivo do Museu Paulista. Como demonstra Sheets-Pyenson, outros "museus coloniais" se utilizavam do mesmo expediente, em menor ou maior escala. Vale conferir o exame que a autora faz das estratégias de compra de espécimes colocadas em prática no National Museum de Melbourne, Austrália. Ver SHEETS-PYENSON, Susan, op. cit., 1988, pp. 72-80.

${ }^{88}$ Essas casas comercializavam (e os Museu Paulista delas adquiria) não apenas espécimes, mas também diversos outros produtos pertinentes às atividades da História Natural: publicações; modelos; materiais didáticos diversos; instrumentos científicos (como lupas e microscópios); ferramentas para taxidermia; instrumentos para coleta de espécimes, etc. Optamos por contabilizar (como pode ser visto no apêndice D) todas as casas comerciais com as quais o Museu manteve algum tipo de contato, mesmo aquelas das quais não adquiriu espécimes, mas apenas outros produtos de História Natural, e mesmo uma da qual não chegou a comprar nada, mas que se reportou ao Museu oferecendo espécimes.
} 
suprimentos para sua coleta, preparação e conservação; além do que Ihering algumas vezes recebia um volume grande de peças para escolher apenas uma parte e devolver o resto ao vendedor. ${ }^{89}$ De todo modo, nosso objetivo aqui não é realizar um mapeamento preciso do comércio internacional de espécimes, mas apenas entender a atuação do Museu Paulista no âmbito dessa rede de comércio.

Para termos uma noção do que era comercializado em termos de espécimes, apresentaremos alguns dados que permitem formular uma ideia do conteúdo e volume dessas compras. Vejamos então exemplos do tipo de material que vendiam para o Museu Paulista as casas comerciais com as quais ele mantinha relações mais intensas.

A empresa de Wilhelm Schlüter foi provavelmente a principal fornecedora estrangeira do Museu. ${ }^{90}$ As remessas dessa casa incluem, por exemplo, um fornecimento de 31 espécimes de caranguejos; ${ }^{91}$ uma remessa com 38 peles de beija-flores "escolhidos dos mais belos, para empalhar",92 além de outras remessas envolvendo répteis, peles e ovos de aves. As aquisições incluem, além de espécimes, equipamentos e suprimentos para as atividades de coleta, preparação e armazenamento de espécimes - principalmente frascos de vidro, mas também encontramos referências à compra de armas, munições, modelos artificiais de plantas e diamantes, aparelho fotográfico, entre outros. Schlüter vendeu também dez museus escolares (para serem enviados às escolas do estado), que continham espécimes empalhados, preparações de metamorfoses de rã e de insetos, além de preparações de órgãos de animais e modelos de partes do corpo humano. ${ }^{93}$

\footnotetext{
${ }^{89}$ Sabemos que parte de um lote de 186 espécimes enviado pelo negociante Hermann Rolle em 1900 foi devolvida. O mesmo aconteceu com outro lote (contendo mamíferos, aves, conchas, répteis e peixes) de 1902. Ver LISTA de espécimes adquiridos de Hermann Rolle, 2/12/1900?. APMP/FMP, Série Prestação de contas; REGISTRO em livro de aquisições, 18/04/1902. APMP/FMP, Série Relações de aquisições.

90 Wilhelm Schlüter (1828-1919), nascido na Alemanha, filho de um entomólogo e malacologista, fundou em 1853 sua empresa fornecedora de espécimes e suprimentos para História Natural, situada em Halle an der Saale. A partir do final do século XIX, a loja passou a ser dirigida por seus filhos. Ver dados biográficos em OBERÖSTERREICHISCHES Landesmuseen. Zobodat - Zoologisch-Botanische Datenbank: banco de dados. Disponível em: http://www.zobodat.at. Acesso em: março de 2012.

${ }_{91}$ CONTA de Wilhelm Schlüter, Halle an der Salle, 26/07/1894. APMP/FMP, Série Prestação de contas.

${ }_{92}$ REGISTRO em livro de aquisições, 03/07/1908. APMP/FMP, Série Relações de aquisições.

${ }^{93}$ OFícIO de Hermann von Ihering ao Secretário do Interior, São Paulo, 12/08/1896. APMP/FMP, Série Correspondência; RECIBO do Brasilianische Bank für Deutschland referente a pagamento a W. Schlüter por 10 museus escolares, 23/11?/1897. APMP/FMP, Série Prestação de contas; OFícIO do Secretário do Interior ao diretor do Museu Paulista, 27/03/1897. APMP/FMP, Série Correspondência.
} 
Já os fornecimentos da empresa O. Staudinger \& A. Bang-Haas consistem essencialmente de insetos e, em menor escala, de alfinetes entomológicos. ${ }^{94}$ Podemos citar, a título de exemplo: um fornecimento de 358 espécimes de insetos (das ordens Hymenoptera, Diptera, Hemiptera e Orthoptera) por 200 marcos; ${ }^{95}$ outro de "uma coleção de belíssimos coleópteros raros, para a coleção exposta no Museu". ${ }^{96}$

Entre as remessas feitas ao Museu por Hermann Rolle,${ }^{97}$ temos: uma contemplando uma coleção de peixes e répteis de Porto Rico, uma coleção de diversos mamíferos argentinos e uma coleção de 23 peles de pássaros do Equador, correspondendo a um valor total de 365 marcos; ${ }^{98}$ uma de Lepidópteros de Yungas de La Paz (Bolívia) somando 450 marcos; ${ }^{99}$ entre outras envolvendo conchas, além de ovos e ninhos de pássaros.

As aquisições provenientes do negociante londrino W. F. H. Rosenberg ${ }^{100}$ referem-se a mamíferos, peixes, aves e ovos de pássaros. Temos, por exemplo, uma remessa de coleção de couros de mamíferos $(£ 13.9 .10) ;{ }^{101}$ outra de 53 pássaros $(£ 15.16 .6),{ }^{102}$ entre outras.

\footnotetext{
94 Otto Staudinger (1830-1900) foi um entomólogo alemão especializado em lepidópteros, o qual passou a comercializar espécimes de História Natural por volta de 1858. Em 1879 seu futuro genro, o também entomólogo Andreas Bang-Haas (1846-1925), tornou-se seu sócio na empresa sediada em Dresden. Ver Seebold, T. L. F. Notice Nécrologique sur le Dr. Otto Staudinger. Annales de la Société Entomologique de France, 70, 1901, pp. 6-7 e ANONIMO. Andreas Bang-Haas. Zeitschrift des Österr. Entomologen Vereines, 10, 3, mar. 1925, pp. 21-22.

${ }^{95}$ CONTA de O. Staudinger \& A. Bang-Haas, Blasewitz-Dresden, 20/08/1895. APMP/FMP, Série Prestação de contas.

${ }_{96}$ REGISTRO em livro de aquisições, janeiro de 1907. APMP/FMP, Série Relações de aquisições.

97 O alemão Franz Hermann Rolle (1864-1929) iniciou seu negócio de venda de espécimes de História Natural - "Kosmos - Naturhistorisches Institut" - em 1889 em Berlim.

${ }^{98}$ CONTA de Hermann Rolle, Berlim, 08/07/1902. APMP/FMP, Série Prestação de contas.

${ }^{99}$ CONTA de Hermann Rolle, Berlim, 18/07/1903. APMP/FMP, Série Prestação de contas.

${ }_{100}$ William Frederick Henry Rosenberg (1868-1957) iniciou suas atividades como comerciante de espécimes de História Natural em 1897. Poucos anos antes de iniciar seu negócio, o próprio Rosenberg realizou duas expedições à Colômbia e ao Equador. Após dar início a sua empresa, empregou por dois anos, 1898 e 1899, coletores nessas regiões, os quais the abasteciam de espécimes. Também recebia espécimes de diversos outros coletores instalados em várias partes do globo. Ver OBERÖSTERREICHISCHES Landesmuseen. Zobodat - Zoologisch-Botanische Datenbank: banco de dados. Disponível em: http://www.zobodat.at. Acesso em: março de 2012.

${ }^{101}$ CONTA de W. F. H. Rosenberg, sem data. APMP/FMP, Série Prestação de contas.

${ }^{102}$ CONTA de W. F. H. Rosenberg, Mid. Summer, 1906. APMP/FMP, Série Prestação de contas.
} 
Ao se constatar que havia, portanto, uma prática de aquisição de espécimes por meio de negociantes europeus, particularmente alemães, algumas questões se colocam: por que razão importar da Europa espécimes sul-americanos (inclusive brasileiros)? Não seria mais fácil e mais barato obter esses espécimes aqui mesmo, enviando o naturalista viajante do Museu para coletar o material desejado? Ou mesmo adquirindo os espécimes de negociantes brasileiros e sul-americanos?

Quanto ao primeiro ponto, já nos referimos às dificuldades encontradas na obtenção direta desses espécimes (isto é, na coleta do material pelo próprio estafe do Museu). Quanto à aquisição de espécimes de comerciantes residentes no Brasil, embora fosse igualmente uma prática corrente, parece-nos que algumas especificidades faziam com que ela não suprisse totalmente as demandas da instituição, obrigando-a a importar espécimes da Europa e dos Estados Unidos. Esse mercado nacional parecia ser pouco maduro, fazendo com que o Museu tivesse dificuldades em adquirir determinados espécimes, ou em adquirir espécimes convenientemente preparados e classificados.

Embora existissem, como vimos, caçadores e preparadores atuantes no país que se dedicavam a vender espécimes, essa oferta não deveria ser tão grande quanto na Europa. Ihering, apresentando justificativas junto ao Secretário do Interior para a aquisição de materiais científicos no estrangeiro, afirma o que segue:

(...) nem nesta capital e nem no Rio de Janeiro existem casas comerciais que vendem instrumentos, alfinetes e mais aparelhos necessários para a caça e preparação de insetos e muito menos ainda casas especialistas que negociem com insetos para coleções científicas. ${ }^{103}$

Em certos casos, parecia ser difícil encontrar na mão de coletores nacionais determinadas espécies (mesmo no caso de espécies ocorrentes no estado de São Paulo). Isso explicaria e justificaria a aquisição de certos espécimes junto a comerciantes europeus. ${ }^{104}$

\footnotetext{
${ }^{103}$ Ofíclo [de Hermann von Ihering] ao Secretário do Interior, São Paulo, 27/03/1913. APMP/FMP, Série Correspondência.

${ }^{104} \mathrm{Em}$ ofício ao Secretário do Interior, datado de 1898, Ihering solicita autorização para adquirir uma coleção de aves do negociante alemão Hermann Rolle, sob a justificativa de não ter encontrado por aqui diversos exemplares. Ofíclo ao Secretário do Interior, São Paulo, 20/07/1898. APMP/FMP, Série Correspondência.
} 
Algo que também deve ser levado em conta é a necessidade de obter espécimes bem preparados. Mesmo que existissem indivíduos no Brasil atuando na coleta de espécimes com fins comerciais, talvez seus produtos não estivessem de acordo com os métodos de preparação considerados adequados por Ihering. Ferdinand Schwanda, coletor que atuava no Maranhão, em carta de 1910 nos permite saber que o diretor fazia algumas especificações quanto ao modo de preparação dos animais a serem enviados ao Museu. Na carta em questão, Schwanda afirma: "Ultimamente eu preparei uma razoável quantidade de peles de bugios, monos e de bichos preguiça, todas de acordo com a sua receita, com sal e alúmen, atendendo assim certamente às suas exigências". ${ }^{105}$

Outro motivo para importar seria a vantagem de se obter espécimes já corretamente classificados. Conforme explica Ihering:

\begin{abstract}
Sendo a coleção de insetos deste Museu sem dúvida a melhor e a mais rica do Brasil e sendo-nos, por conta da imensa literatura e do limitado pessoal da repartição, impossível de ocupar-nos de todos os grupos aproveito de mês em mês a ocasião de comprar insetos brasileiros exatamente classificados no exterior.
\end{abstract}

Esta ocasião agora me é dada por ofertas da casa Staudinger e Bang-Haas em Dresden e peço a V. E. autorização para comprar no correr deste ano daquela casa insetos até a quantia de $600 \$ 000 .^{106}$

A questão da classificação era de fato importante na comercialização de produtos de História Natural. Hermann Rolle, oferecendo uma remessa de lepidópteros para o Museu Paulista, informa que tem "muito e bem classificado material" de algumas famílias. Oferece ainda espécimes de mamíferos sulamericanos classificados pelo zoólogo Paul Matschie. ${ }^{107} \mathrm{O}$ fato de serem classificados por uma zoólogo conhecido garantiria a exatidão da identificação do material. Afinal, conforme reclamava Ihering, espécimes comprados de negociantes poderiam vir erroneamente classificados, prejudicando os trabalhos científicos:

\footnotetext{
105 CARTA em alemão, com tradução anexa, de Ferdinand Schwanda [a Hermann von Ihering], Miritiba, 16/07/1910. APMP/FMP, Série Correspondência.

${ }_{106}$ Ofíclo [de Hermann von Ihering] ao Secretário do Interior, São Paulo, 04/05/1909. APMP/FMP, Série Correspondência (grifo nosso).

${ }_{107}$ CARTA em alemão, com tradução anexa, de Hermann Rolle, a Hermann von Ihering, Berlim, 17/08/1912. APMP/FMP, Série Correspondência. Paul Matschie (1861-1926) começou a trabalhar no Museum für Naturkunde de Berlim em 1883, tendo se tornado a partir de 1895 o curador (Kustos) da coleção de mamíferos. Ver KöSTERING, Susanne, op. cit., 2003, p. 199.
} 
Grande, e talvez mesmo a maior parte dos ovos sul-americanos acumulados em vários Museus e coleções particulares é material comprado de comerciantes e cheio de enganos. Não só que eles não se acham na altura do estudo científico para fiscalizar os dados que Ihes foram transmitidos, mas também os próprios fornecedores dos ovos causam enganos e muitas vezes são vítimas de mistificações por parte dos caçadores, que Ihes juntam um pássaro qualquer ao ninho que vendem. ${ }^{108}$

Por um motivo ou por outro, o Museu recorria com alguma regularidade a esses revendedores de espécimes instalados no continente europeu.

\subsection{A tessitura da rede}

A maior parte desse material importado pelo Museu Paulista devia consistir em espécimes sul-americanos. ${ }^{109}$ Ora, se os espécimes eram naturais da América do Sul, o princípio dessa cadeia comercial devia estar instalado na parte de cá do Atlântico. Ou seja, ou esses negociantes realizavam expedições a fim de coletar espécimes na América do Sul (ou contratavam alguém para realizá-las), ou indivíduos residentes em nosso continente vendiam espécimes para tais empresas europeias, as quais se incumbiam de revender o material na Europa (e inclusive, como vemos pelo caso do Museu Paulista, revendiam para instituições da própria América do Sul).

Uma carta do comerciante francês E. Le Moult, na qual oferece seus serviços ao diretor do Museu Paulista, indica a existência de caçadores responsáveis pela captura de espécimes que seriam remetidos para lojas europeias:

Permettez-nous d'attirer votre attention sur notre richissime stock en
Insectes de tous ordres et de tous pays, notamment aussi de l'Amerique
méridionale, où nous entretenons de nombreux chasseurs expérimentés, en
Guyane française, Pérou, Argentine etc. Si vous vouliez avoir l'obligeance

\footnotetext{
108 IHERING, Hermann von. Novas contribuições para a Ornithologia do Brazil. Revista do Museu Paulista, 9, 1914, pp. 420-421.

${ }^{109}$ No caso das aves, a não ser por raras exceções, os espécimes importados de revendedores europeus eram originários da América do Sul, particularmente da Venezuela, da Colômbia e do Equador. Alguns tinham inclusive origem brasileira. Ver MUSEU Paulista: Catálogo Accessional: Aves. Tomos 1 e 2. Acervo da Seção de Ornitologia do Museu de Zoologia da USP.
} 
de nous faire informer en quels groupes spéciaux vous tenez à récevoir un envoi à choix, nous vous en ferions parvenir volontier un.

Nos prix sont modiques, aussi attachons-nous de l'importance à ce que tous les exemplaires sortant de notre maison portent invariablement une etiquette avec indication de provenance (localité) exacte. ${ }^{110}$

Como vemos, o trecho citado indica que o negociante francês mantinha caçadores na Argentina, Peru e Guiana Francesa. Algo parecido ocorria no Brasil: indivíduos residentes no país se encarregavam de enviar espécimes para comerciantes europeus. Christiano Enslen, por exemplo - coletor residente na colônia de São Lourenço, Rio Grande do Sul, o qual enviou espécimes ao Museu Paulista durante toda a gestão de Ihering -, menciona, em uma carta ao diretor, a venda de borboletas ao negociante alemão Otto Staudinger. ${ }^{111}$ No livro de tombo de aves, existe registro de um espécime comprado de Schlüter que foi coletado por Ricardo Krone em Iguape. Outro, igualmente comprado de Schlüter, havia sido coletado por Devantier em Desterro, Santa Catarina. Sinal que tais comerciantes, vendedores de espécimes para o Museu Paulista, também forneciam material para revendedores europeus. ${ }^{112}$

Além disso, um trecho de relatório escrito por Rodolpho von Ihering nomeia outros coletores que tanto vendiam espécimes para o Museu Paulista quanto exportavam material para a Europa:

Especialmente em nosso Estado conseguimos entrar em relação com um certo número de caçadores que, ensinados pelo nosso preparador já agora nos preparam bons couros ou conservam os animais em álcool e assim constantemente Ihes compramos bom material. Naturalmente as espécies mais comuns se repetem frequentemente, de modo que limitamo-nos a fazer a seleção do que julgamos aproveitável para nossas coleções, devolvendo-lhes o resto para a venda na Europa. Tais senhores são: Mathias Wacket na Serra do Mar; Francisco Günther na llha de $S$. Sebastião; Otto Dreher em Franca. Ao Snr. H. Lüderwaldt, que a princípio nos prestava iguais serviços, fazendo caçadas em Itatiaia, já agora

110 CARTA de E. Le Moult a Hermann von Ihering, Paris, 28/07/1914. APMP/FMP, Série Correspondência (grifo nosso).

${ }^{111}$ CARTA em alemão, com tradução anexa, de Christiano Enslen a Hermann von Ihering, São João da Reserva, 27/06/1909. APMP/FMP, Série Correspondência.

${ }_{112}$ MUSEU Paulista: Catálogo Accessional: Aves. Tomos 1. Registros número 279 e 2461. Acervo da Seção de Ornitologia do Museu de Zoologia da USP. 
conseguimos contratar para o trabalho constante em nossos laboratórios $(\ldots.) .^{113}$

O fato de esses coletores venderem espécimes tanto para o Museu Paulista quanto para compradores europeus sugere a existência de um mercado internacional de produtos de História Natural algo dinâmico. Documentos existentes no arquivo do Museu Paulista permitem-nos compreender um pouco mais sobre essas redes comerciais e sobre o papel que tinha nelas o Museu. Os documentos indicam, como veremos, que Ihering, enquanto diretor do Museu Paulista, mais do que devolver os espécimes que não the interessavam para que os coletores tentassem vender o material na Europa, encarregava-se ele mesmo de intermediar o contato com negociantes europeus.

Ihering era, inclusive, procurado por colecionadores e instituições estrangeiros interessados em comprar espécimes, os quais solicitavam sua intermediação junto a coletores atuantes no Brasil. Esse é o caso de um indivíduo chamado Herbert von Rothkirch, o qual escreve ao diretor do Museu afirmando necessitar comprar determinados coleópteros que poderiam ser encontrados com Hermann Lüderwaldt. Pede então que Ihering intermedeie o contato com tal coletor. ${ }^{114}$

Outro caso é o de Levi Mengel, diretor do Reading Public Museum and Art Gallery, Pensilvânia, que se dirige ao diretor do Museu Paulista com solicitação de intermediação: "I am writing to you to inquire if you can place me into communication with any collectors or persons from whom I can either purchase or exchange butterflies in good condition." 115

Outro cientista dos Estados Unidos, T. S. Palmer, também recorreu a Ihering, solicitando espécimes de puma. Deu inclusive instruções sobre a preparação do material que seria comprado:

I am glad to know that your collectors can secure us specimens of Felis concolor. We should like at least one first-class skin with skull at the price

\footnotetext{
${ }^{113}$ IHERING, Rodolpho von. O Museu Paulista nos annos de 1903 a 1905. Revista do Museu Paulista, 7, 1907, pp. 9-10 (grifo nosso).

114 CARTA em alemão, com tradução em anexo, de [Herbert] von Rothkirch a Hermann von Ihering, Lübben, 03/10/1909. APMP/FMP, Série Correspondência. Lüderwaldt era funcionário do Museu Paulista desde 1905 - ver Apêndice B.

${ }^{115}$ CARTA de Levi Mengel a Hermann von Ihering, Reading, Pensilvânia, 15/03/1916. APMP/FMP, Série Correspondência.
} 
you mention, 20\$00 and also several skulls without skins. The odd skulls should be labeled with sex and locality, and while they need not be thoroughly cleaned, care should be taken not to injure the small bones about the base of the skull in removing the muscles. ${ }^{116}$

Por outro lado, coletores atuantes no Brasil também se dirigiam ao Museu Paulista solicitando informações a respeito do envio de materiais para revendedores europeus. Joaquim C. Véras, de Manaus, dirige-se ao zelador Rodolpho von Ihering afirmando pretender realizar expedição ao interior do estado do Amazonas para coletar plantas e lepidópteros. Após solicitar informações sobre a preparação de borboletas, pede contatos para a venda do material na Alemanha:

\begin{abstract}
Sabendo que há alguma procura de raros exemplares de borboletas, muito penhorado ficaria a $V$. Excia. se pudesse-me fornecer alguns esclarecimentos sobre estas espécies e algumas plaquetes (sic) sendo possível. Conhece V. Excia. na Alemanha alguma firma comercial a quem possa dirigir-me? Qual?

Aguardando pressuroso vossa resposta, certo não me esquecerei de retribuir a vossa Excia. com alguns espécimes da minha exploração entomológica. ${ }^{117}$
\end{abstract}

Outro indivíduo, Cristovam Barreto, interessado em vender material arqueológico, solicita a lhering que envie prospectos, propagandeando os objetos que desejava vender, aos principais museus nacionais e estrangeiros. Informa ainda que tentaria ir à Bahia, “(...) onde poderia melhor litografar as peças que lá deixei guardadas, e as que tenho obtido depois da minha vinda do Rio, e que não são poucas." 118

Esse papel intermediador de Ihering e seu Museu Paulista poderá ser mais bem compreendido examinando-se o caso de um coletor específico: Ferdinand Schwanda. Travando relações com Ihering, Schwanda reunirá condições para se estabelecer como coletor profissional e passar a integrar as redes de comércio de

\footnotetext{
${ }^{116}$ CARTA de T. S. Palmer, Biological Survey, U. S. Department of Agriculture, a Hermann von Ihering, Washington, 10/09/1900. APMP/FMP, Série Correspondência.

117 CARTA de Joaquim C. Véras a Rodolpho von Ihering, Manaus, 22/07/1914. APMP/FMP, Série Correspondência.

${ }_{118}$ CARTA de Cristovam Barreto a Rodolpho von Ihering, Amargosa, 21/08/1904. APMP/FMP, Série Correspondência.
} 
espécimes que conectavam caçadores, negociantes e museus instalados em ambos os lados do Atlântico.

\subsection{O caso de Ferdinand Schwanda}

Ferdinand Schwanda, coletor autônomo residente no Maranhão, além de vender espécimes para o Museu Paulista, manteve correspondência com Ihering, correspondência essa que apresenta elementos os quais nos possibilitam refletir sobre sua atuação enquanto caçador e negociante de espécimes científicos. ${ }^{119}$ Nossa análise da correspondência enfatizará como o estabelecimento de relações entre Schwanda e Ihering foi fundamental para que o primeiro tenha obtido algum sucesso enquanto coletor e vendedor de espécimes científicos no Brasil. As relações mantidas com o diretor do Museu Paulista permitiam a Schwanda mais facilmente expedir os espécimes para compradores europeus, bem como obter os suprimentos necessários para suas atividades de coleta.

Mas, afinal, quem foi Ferdinand Schwanda? Por que se estabeleceu no Brasil? Qual sua relação com as instituições científicas e com o mercado de espécimes de História Natural? Como suas atividades colaboraram com o desenvolvimento de conhecimentos sobre a natureza brasileira?

Pouco sabemos sobre Schwanda. Pode ser que tenha nascido em algum país germânico, uma vez que suas cartas dirigidas a lhering são redigidas em alemão. De acordo com Hellmayr, ele se estabeleceu no Maranhão em 1905, de onde passou a enviar espécimes para a Europa. Hellmayr teve oportunidade de examinar materiais coletados por Schwanda pertencentes ao Museu Paulista e a diversos museus europeus, como o Museu de História Natural em Tring, o Museu Real de História Natural de Sófia, Bulgária, além dos museus de Viena, Munique e Frankfurt am Main. Ainda segundo o ornitólogo austríaco, Schwanda coletou inicialmente em

\footnotetext{
${ }^{119}$ Existem, no arquivo do Museu Paulista, 20 cartas enviadas por Ferdinand Schwanda. Embora o destinatário não seja nominado, presume-se que as cartas são endereçadas a Hermann von Ihering. Das 20 cartas, todas redigidas em alemão, 7 contam com traduções para o português, de autoria desconhecida, armazenadas junto aos documentos originais. Além disso, existem no arquivo recibos referentes a espécimes adquiridos de Schwanda, além de registros de compra e cartas de outros emissores que fazem referência ao coletor.
} 
São Luiz, Boa Vista e Primeira Cruz, tendo, mais tarde, passado a atuar na região de Miritiba - todos no Maranhão. ${ }^{120}$

De acordo com Ihering, Schwanda faleceu no dia 10 de junho de $1913 .^{121}$ Após sua morte, seu filho J. Karl Schwanda continuou a fornecer espécimes para o Museu Paulista, conforme atestam documentos encontrados no arquivo da instituição.

Não temos maiores informações sobre a vinda de Schwanda para o Brasil. É possível que já trabalhasse como caçador profissional, pois em carta a lhering refere-se ao fato de ter percorrido outras regiões do mundo - afirma que já havia estado em todo o sul da Europa, no oeste asiático e no norte da África. ${ }^{122}$ Pode-se supor que tenha realizado essas viagens a fim de coletar espécimes de História Natural. Mas não sabemos se viajou por conta própria, ou se suas expedições foram comissionadas por alguma instituição científica ou por algum comerciante de espécimes.

No caso de sua estada no Brasil, tudo indica que tenha se estabelecido aqui por conta própria, na expectativa de vender o produto de suas coletas a museus ou revendedores de espécimes sediados na Europa. Afinal, a correspondência mantida com Ihering trata da venda de espécimes não só ao Museu Paulista, mas também a institutos científicos e negociantes sediados no velho continente.

Podemos saber um pouco mais sobre a atuação de Schwanda por meio dessas cartas por ele enviadas ao Museu Paulista. Nelas, o coletor trata sobretudo de assuntos relativos às transações comerciais mantidas com o Museu: oferece determinados espécimes por ele caçados, cobra pagamentos devidos, etc. Além disso, aborda, por vezes, outros dois assuntos os quais nos interessa tratar aqui. Primeiro, o envio de espécimes para outros clientes. Segundo, as dificuldades envolvidas na obtenção dos suprimentos necessários às atividades de coleta, preparação e envio de espécimes.

\footnotetext{
${ }^{120}$ HelLmayr, Carl E. A contribution to the ornithology of northeastern Brazil. Chicago: Field Museum of Natural History, 1929 (Zoological Series, 12, 18), pp. 235-238.

121 IHERING, Hermann von. Os bugios do genero Alouatta. Revista do Museu Paulista, 9, 1914, pp. 231-232.

122 CARTA, em alemão, de Ferdinand Schwanda [a Hermann von Ihering], Miritiba, 27/09/1907. APMP/FMP, Série Correspondência.
} 


\subsubsection{Em busca de clientes}

Comercializar os espécimes coletados no Brasil nem sempre era tarefa fácil. Fazia-se necessário encontrar clientes interessados em adquiri-los por preços que valessem a pena para o coletor, já que os custos com frete e aquisição de suprimentos para caça, preparação e envio eram altos.

Por isso, Schwanda estava sempre em busca de clientes com os quais pudesse realizar negócios vantajosos. Já na primeira carta remetida a lhering existente no arquivo do Museu Paulista, o caçador solicita que o diretor do Museu o comunique caso surja um bom cliente no Rio ou em São Paulo: "Eu peço a vossa senhoria que, se em São Paulo ou no Rio existir uma loja de produtos de História Natural séria, faça a gentileza de me enviar o endereço, para que eu me livre do meu estoque atual (...)" (trad. nossa). ${ }^{123}$

Conversas posteriores com o diretor do Museu versavam sobre o interesse de Schwanda em encontrar algum revendedor que pudesse ficar com todo o material por ele coletado. Diz que seu ideal seria localizar uma firma que aceitasse tudo aquilo que lhering não desejasse. ${ }^{124}$ Escoando toda a sua produção para um só destino, supomos, seriam poupados custos com transporte, além de se evitar o encalhe de mercadorias. Todavia, não sendo factível essa situação ideal, Schwanda se via obrigado a recorrer a mais de um cliente.

Mesmo precisando diversificar seu leque de compradores, foi aprofundando suas relações com um desses clientes - o Museu Paulista, por meio de seu diretor, Hermann von Ihering - que Schwanda conseguiu criar as condições necessárias para seu estabelecimento como coletor profissional no Brasil. Schwanda e Ihering fizeram um acordo pelo qual o primeiro deveria enviar ao Museu Paulista o produto total de suas coletas. Com todo esse material em São Paulo, Ihering escolhia o que interessava ao seu Museu e providenciava o envio do restante à Europa - sendo

\footnotetext{
123 "Ich bitte Euer Hochgeboren, wenn in S. Paulo oder in Rio ein reelles Naturaliengeschäft existirt mir güthigst die Adreße zukommen laßen, damit ich meinen gegenwärtigen Vorrath los werde (...)". CARTA, em alemão, de Ferdinand Schwanda [a Hermann von Ihering], Boa Vista, 14/08/1906. APMP/FMP, Série Correspondência.

${ }_{124}$ CARTA, em alemão, de Ferdinand Schwanda [a Hermann von Ihering], Boa Vista, 04/02/1907. APMP/FMP, Série Correspondência.
} 
que caberiam ao Museu Paulista as despesas tanto do transporte do Maranhão até São Paulo, quanto de São Paulo para a Europa. ${ }^{125}$

Desse modo, o Museu Paulista tinha a vantagem de poder escolher o que the interessasse das coletas de Schwanda antes que qualquer outro cliente o fizesse. $E$ contava ainda com a conveniência de ter as peças em mãos para poder fazer a escolha - não ficando refém de catálogos -, podendo assim conferir a qualidade do material e se a espécie correspondia ao apontado pelo coletor. Schwanda, por seu lado, tinha a vantagem de ter as despesas com transporte até a Europa (bem como até São Paulo) pagas pelo Museu Paulista.

Expedidas a partir do Museu Paulista, ou então diretamente do Maranhão, remessas de espécimes coletados por Schwanda eram enviadas a instituições científicas e revendedores de espécimes na Europa.

No que se refere às instituições científicas, na correspondência enviada a lhering, o caçador dá informações sobre o envio de espécimes para o Museu de História Natural em Tring, Inglaterra e à Direção dos Institutos Científicos e da Biblioteca do Príncipe da Bulgária, em Sófia. Conforme já indicamos, Hellmayr menciona ter consultado materiais coletados por Schwanda em outros museus europeus. Mas não sabemos dizer se tais materiais foram vendidos diretamente para essas instituições pelo próprio Schwanda, ou se o foram por revendedores de espécimes com os quais o caçador também mantinha relações comerciais.

Quanto a esses negociantes de espécimes instalados na Europa, a correspondência enviada a Ihering nos permite saber que Schwanda forneceu materiais aos revendedores alemães Wilhelm Schlüter, Hermann Rolle e Otto Tockhorn, bem como para o londrino William Rosenberg.

No que se refere a Schlüter, Schwanda diz a Ihering, em carta datada de 1906, que havia enviado ao negociante alemão uma coleção de mamíferos, bem como sua produção de peles de aves do ano todo. ${ }^{126}$ Aparentemente, as relações comerciais com Schlüter devem ter se mantido, já que ele volta a ser citado por

\footnotetext{
${ }^{125}$ CARTA, em alemão, de Ferdinand Schwanda [a Hermann von Ihering], Miritiba, 27/09/1907. APMP/FMP, Série Correspondência.

${ }_{126}$ CARTA, em alemão, de Ferdinand Schwanda [a Hermann von Ihering], Boa Vista, 14/08/1906. APMP/FMP, Série Correspondência.
} 
Schwanda em duas cartas de 1909 - em uma delas, Schwanda comenta com o diretor do Museu Paulista que, por conta das chuvas, toda a coleta de um ano não havia ainda sido enviada para o negociante. ${ }^{127}$

Schwanda também manteve relações comerciais com o revendedor alemão Hermann Rolle, mas interrompeu tais negócios devido a divergências quanto ao valor pago pelos espécimes enviados. Pelo menos é isso que ele informa a lhering. Em carta de 1907, Schwanda se refere a Rolle como um trapaceiro, e pede para o diretor do Museu Paulista não lhe enviar mais espécimes seus. ${ }^{128}$ Já em carta do ano seguinte, justificando sua falta de interesse na coleta de borboletas - material que Ihe havia sido solicitado pelo revendedor alemão Otto Tockhorn -, Schwanda relata que teve uma experiência negativa envolvendo Rolle:

Borboletas, que são seu principal desejo [de Otto Tockhorn], infelizmente não posso enviar a ele, porque eu tive experiências muito ruins a respeito. O preço prometido nunca é completamente pago, ao contrário, põe-se defeito na coisa de todos os lados. Assim Rolle, em Berlim, deu-me absolutamente nada por mil borboletas (...) (trad. nossa). ${ }^{129}$

O caçador atuante no Maranhão também destinou espécimes para o negociante londrino William Rosenberg. E, nesse caso, a colaboração do diretor do Museu Paulista com Schwanda foi ainda mais estreita. Além de providenciar o envio dos materiais para a Europa, arcando com as despesas de transporte - conforme o acordo já descrito -, Ihering facilitou a atuação de Schwanda no Brasil intermediando seus contatos comerciais com Rosenberg.

Em carta de fevereiro de 1907, Schwanda pergunta a Ihering se é preciso escrever algo a Rosenberg, ou se bastaria aguardar. ${ }^{130}$ Sinal de que Ihering já havia

\footnotetext{
${ }^{127}$ CARTAS em alemão, com traduções anexas, de Ferdinand Schwanda [a Hermann von Ihering], Miritiba, 29/01/1909 e 30/05/1909. APMP/FMP, Série Correspondência.

${ }_{128}$ CARTA, em alemão, de Ferdinand Schwanda [a Hermann von Ihering], Miritiba, 27/09/1907. APMP/FMP, Série Correspondência.

129 "Schmetterlinge was sein Hauptwunsch ist kann ich inm leider keine senden, weil ich in dieser Hinsicht sehr schlechte Erfahrungen gemacht habe der versprochene Preis wird nie voll ausgezahlt sondern wird die Sache von allen Seiten bemängeln so hat mir Rolle in Berlin für 1.000 Schmeterlinge absolut nichts gegeben (...)". CARTA, em alemão, de Ferdinand Schwanda [a Hermann von Ihering], Miritiba, 12/09/1908. APMP/FMP, Série Correspondência.

${ }_{130}$ CARTA, em alemão, de Ferdinand Schwanda [a Hermann von Ihering], Boa Vista, 04/02/1907. APMP/FMP, Série Correspondência.
} 
enviado ao negociante londrino uma remessa de espécimes coletados por Schwanda.

Ainda em 1907, Schwanda lembra Ihering de que o mesmo havia enviado no ano anterior uma remessa de 59 peles de pássaros para Rosenberg, pela qual ele, Schwanda, ainda não havia recebido nada. Diz então para lhering não voltar a enviar espécimes seus para Rosenberg:

\begin{abstract}
Por isso, peço-Ihe para não enviar novamente minhas coisas que aí estão a Rosenberg \& Son em Londres, nem ao trapaceiro do Rolle em Berlim, mas sim à prezada Direção das Instituições Científicas e da Biblioteca de Sua Alteza o Príncipe da Bulgária, em Sófia, Bulgária, através de um comissário de Hamburgo (...) (trad. nossa). ${ }^{131}$
\end{abstract}

Mais tarde, o caçador voltou atrás, indicando a Ihering que os materiais sem serventia para o Museu Paulista deveriam continuar seguindo para Londres, já que os preços praticados por Rosenberg eram muito bons, segundo o próprio Schwanda. ${ }^{132} \mathrm{O}$ caçador referiu-se outras vezes a Rosenberg nas cartas remetidas a Ihering, sempre pedindo informações sobre seus espécimes enviados ao negociante londrino e cobrando o recebimento dos pagamentos devidos.

Mais tarde, em carta de 1909, Schwanda diz que ele mesmo entrou em contato com Rosenberg, o qual aceitou receber mais remessas suas para venda. Acrescenta que ele pretendia efetivar o negócio, já que os preços praticados pelo revendedor londrino eram muito vantajosos. ${ }^{133}$ Schwanda parece ter preferido tomar as rédeas das negociações com Rosenberg - tanto é assim que, nas demais cartas existentes no arquivo do Museu Paulista, o revendedor inglês não é mais mencionado.

Algumas cartas remetidas por Rosenberg a Ihering permitem-nos entender mais detalhadamente como se dava essa relação entre o coletor Schwanda, o

\footnotetext{
131 "Ich bitte Sie daher[?] meine dort liegenden Sachen nicht wieder an Rosenberg \& Son in London und ja nicht an den Gauner Rolle in Berlin sondern:/ An die geehrte/ Direction der wißenschafftlichen Institutionen und der Bibliotek/ S. R. Hoheit des Fürsten von Bulgarien/ in Sofia Bulgarien/ durch einen Hamburger Comißioner (...) senden zu wollen." CARTA, em alemão, de Ferdinand Schwanda [a Hermann von Ihering], Miritiba, 27/09/1907. APMP/FMP, Série Correspondência.

${ }^{132}$ CARTAS, em alemão, de Ferdinand Schwanda [a Hermann von Ihering], Miritiba, 15/03/1908 e 05/09/1908. APMP/FMP, Série Correspondência.

${ }_{133}$ CARTA em alemão, com tradução anexa, de Ferdinand Schwanda [a Hermann von Ihering], Miritiba, 07/09/1909. APMP/FMP, Série Correspondência.
} 
Museu Paulista e os comerciantes europeus. As três cartas remetidas por Rosenberg, ao longo do primeiro semestre de 1908, tratam de um conjunto de espécimes coletados por Schwanda e enviados a Londres a fim de que fossem vendidos pelo negociante inglês. A primeira carta informa:

I enclose statement of specimens sold to Christmas 1907 for c/c[?] of Mr. Schwanda, showing[?] a balance to this credit of $£$ 11.11.7. Will you kindly let me know how I am to dispose of this sum. Shall I transfer it to the credit of the S. Paulo Museum, when you will be able to order specimens to that value, so[?] you can[?] then pay the actual money to Mr. Schwanda. ${ }^{134}$

$\mathrm{Na}$ segunda carta, Rosenberg informa que envia anexo um cheque para Schwanda, sinal de que lhering preferiu que o próprio negociante inglês pagasse o caçador, ao invés de o Museu o fazer em troca de ficar com o saldo das vendas para ser utilizado futuramente adquirindo espécimes da casa londrina. Além disso, informa que ainda estavam sob sua posse cerca de 190 pássaros, 16 mamíferos, 7 crâneos antigos e 3 lagartos pertencentes a Schwanda. Por fim, afirma ter esperanças de conseguir vender muitos desses materiais e pede paciência ao coletor: "If Mr. Schwanda will have patience I will do my best for him, I will at least endeavour to obtain good prices (...)". ${ }^{135}$

$\mathrm{Na}$ terceira carta, Rosenberg informa que havia vendido espécimes de Schwanda que somavam £ 3.12.- e que lançaria esse valor como crédito em favor do Museu Paulista, pedia então que Ihering pagasse a Schwanda a soma correspondente. ${ }^{136}$

Depois da morte de Schwanda, seu filho continuou os negócios do pai, ainda com a colaboração de Ihering. Bruno Lobo, diretor do Museu Nacional, em carta ao diretor do Museu Paulista, refere-se a caixa contendo peles coletadas por Karl Schwanda que deveria ser despachada do Museu Paulista para a instituição do Rio de Janeiro. Em documento anexo, cópia de uma carta de Bernhard Blum a Bruno Lobo, informa-se que:

\footnotetext{
${ }^{134}$ CARTA de W. F. H. Rosenberg a Hermann von Ihering, Londres, 08/01/1908. APMP/FMP, Série Prestação de contas.

${ }^{135}$ CARTA de W. F. H. Rosenberg a [Rodolpho] von Ihering, Londres, 18/03?/1908. APMP/FMP, Série Prestação de contas.

${ }^{136}$ CARTA, em inglês, de W. F. H. Rosenberg a Hermann von Ihering, Londres, 26/06/1908. APMP/FMP, Série Prestação de contas.
} 
O senhor doutor von Ihering tirou da caixa somente sete couros de animais e cinco ditos de aves, ficando o resto em perfeito estado à disposição do preparador o senhor Carlos Schwanda. Como não é possível devido à terrível guerra, que infelizmente está flagelando a Europa, de exportar o volume para a Alemanha, como estávamos acostumados, pedimos-Ihes 0 obséquio de mandar vir a caixa de São Paulo, escolhendo o que Ihe convier para o importante Museu, que tão dignamente dirigis. ${ }^{137}$

O Museu Paulista, portanto, recebia o material coletado, retinha o que era interessante para a instituição, e se encarregava de remeter o restante para o despachante incumbido de embarcar os espécimes para a Europa. Além disso, Ihering se encarregava ele mesmo de intermediar o contato com negociantes europeus. No caso relatado, por vezes o próprio diretor pagava o coletor, em troca de créditos a serem utilizados na aquisição de outros espécimes comercializados por esses negociantes europeus. ${ }^{138}$

\subsubsection{Suprimentos para caça}

Assim como encontrar bons clientes, remeter os espécimes coletados para os compradores interessados não era tarefa fácil. Conforme atestam as várias queixas de Schwanda em suas cartas a Ihering, era preciso lidar com as incertezas e inseguranças dos correios e dos sistemas de transporte de mercadorias - cartas e encomendas que nunca chegavam, inclusive os pagamentos, deixando o coletor em apuros financeiros por diversas vezes. Além disso, era preciso obter os suprimentos necessários para caçar os animais, prepará-los e os embalar adequadamente - tais

\footnotetext{
${ }^{137}$ CARTA de Bruno Lobo a Hermann von Ihering, 29/12/1915. Contém anexa cópia de carta de Bernhard Blum \& Cia. a Bruno Lobo, datada de 16/12/1915. APMP/FMP, Série Correspondência (grifo nosso). Bernhard Blum deveria ser, provavelmente, um indivíduo que atuava no ramo de importação/exportação em geral, sendo, portanto, responsável por enviar à Europa o material coletado por Schwanda.

${ }_{138}$ Esse tipo de relação envolvendo museus, revendedores de espécimes e caçadores não era exclusividade do Museu Paulista. Köstering refere-se a relações comerciais semelhantes às travadas entre Ihering, Schwanda e casas comerciais europeias. A autora cita as relações envolvendo Paul Matschie, curador da coleção de mamíferos do Museum für Naturkunde de Berlim, e Georg Zenker (1855-1922), colono alemão em Camarões. Matschie se encarregava de intermediar o contato entre Zenker e revendedores de espécimes atuantes na Europa. Ver KösTERING, Susanne, op. cit., 2003, p. 201.
} 
suprimentos, quando não eram inexistentes em território maranhense (no caso de Schwanda), eram muito caros.

As relações mantidas com o diretor do Museu Paulista eram então fundamentais para viabilizar o trabalho de Schwanda. Não apenas no que se refere ao fato de o museu intermediar o envio de espécimes para a Europa, mas também no que diz respeito a Ihering providenciar o envio para Schwanda de suprimentos necessários para seu trabalho (vidros, caixas, munição, etc.).

Schwanda reclama diversas vezes das condições de vida e de trabalho, particularmente das dificuldades em obter os suprimentos necessários às suas atividades de coleta. Em carta de 1907, por exemplo, diz que até aquele momento não havia conseguido abater pássaros pequenos, devido ao fato de não ter chumbo fino. Acrescenta que, embora uma encomenda de $5 \mathrm{~kg}$ de tal chumbo lhe tivesse sido enviada da Europa, o material se encontrava retido na Alfândega. ${ }^{139}$

Em outra carta do mesmo ano, o caçador informa que os peixes dos riachos e lagos locais por ele coletados tinham se estragado, já que lhe tinha sido impossível conservá-los da maneira adequada. Como não encontrava espírito (álcool) por lá, conservou os peixes em cachaça, mas devido à má qualidade da mesma e à longa espera para a expedição do material, acabou por perder os animais. ${ }^{140}$

Sendo impossível obter tais suprimentos no interior do Maranhão, e enfrentando dificuldades para importá-los da Europa, Schwanda precisou recorrer à ajuda do diretor do Museu Paulista para viabilizar sua atuação enquanto coletor de espécimes científicos no Brasil. Ihering enviava de São Paulo alguns dos suprimentos imprescindíveis às atividades do caçador.

Em carta de 1907, Schwanda pede a Ihering que Ihe envie alguns frascos de gargalo grande, ou latas de conservação que sejam fáceis de soldar, bem como

\footnotetext{
${ }^{139}$ CARTA, em alemão, de Ferdinand Schwanda [a Hermann von Ihering], Boa Vista, 04/02/1907. APMP/FMP, Série Correspondência.

${ }_{140}$ CARTA, em alemão, de Ferdinand Schwanda [a Hermann von Ihering], Boa Vista, 15/04/1907. APMP/FMP, Série Correspondência.
} 
vidros pequenos para insetos. Solicita também $5 \mathrm{~kg}$ de chumbo fino para que possa atirar em pássaros pequenos. ${ }^{141}$

Mas, mesmo com a ajuda de Ihering, a situação devia ser muito diferente daquela com a qual Schwanda estava habituado na Europa - onde os negociantes de espécimes científicos deviam comercializar também equipamentos e suprimentos especialmente confeccionados para as atividades de coleta. $^{142}$

Alguns meses após a primeira carta, em nova missiva, Schwanda se refere às latas cilíndricas enviadas por Ihering. Diz ter imaginado que o diretor lhe enviaria latas ou vidros de conservação com fecho mecânico de pressão. Segundo o caçador, as latas enviadas por lhering eram muito difíceis de soldar, de modo que teria sido melhor usar latas de querosene no lugar delas. Reclama ainda do fato de ele ter que arcar com o custo das latas e também do valor alto pago pelas mesmas segundo ele, na Europa elas custariam bem menos. ${ }^{143}$

Mesmo assim, Schwanda continuou contando com a colaboração de Ihering para adquirir alguns suprimentos - munições, ao menos. Em carta de 1909, o coletor pede para o diretor do Museu Paulista não Ihe enviar as 3 mil balas Mauser que havia pedido, pois tinha bastante delas. ${ }^{144}$ Alguns meses mais tarde, em nova carta, Schwanda diz que não tinha mais utilidade para o chumbo fino, já que, sem munição, viu-se obrigado a vender sua espingarda por uma ninharia e, em lugar dela, comprou uma espingarda de vareta. ${ }^{145}$

As relações travadas com o diretor do Museu Paulista desempenhavam papel fundamental para o desenvolvimento das atividades de coletores como Schwanda. Seja para obter os suprimentos imprescindíveis às suas atividades, seja para remeter seus produtos para os compradores europeus, a colaboração de Hermann

\footnotetext{
${ }^{141}$ CARTA, em alemão, de Ferdinand Schwanda [a Hermann von Ihering], Boa Vista, 15/04/1907. APMP/FMP, Série Correspondência.

${ }_{142}$ Para considerações interessantes sobre os equipamentos demandados pelas práticas da História Natural, ver LARSEN, Anne. "Equipment for the field". In: JARDINE, N.; SECORD, J. A.; SPARY, E. C. (eds.). Cultures of natural history. Cambridge: Cambridge University Press, 1996, pp. 358-377.

143 CARTA, em alemão, de Ferdinand Schwanda [a Hermann von Ihering], Miritiba, 27/09/1907. APMP/FMP, Série Correspondência.

${ }^{144}$ CARTA em alemão, com tradução, de Ferdinand Schwanda [a Hermann von Ihering], Miritiba, 29/01/1909. APMP/FMP, Série Correspondência.

${ }_{145}$ CARTA em alemão, com tradução, de Ferdinand Schwanda [a Hermann von Ihering], Miritiba, 07/04/1909. APMP/FMP, Série Correspondência.
} 
von Ihering mostrava-se de suma importância para viabilizar o estabelecimento desses caçadores no Brasil.

\subsection{O Museu Paulista e as redes de comércio}

Ao intermediar os contatos com negociantes sediados na Europa, o Museu Paulista de lhering se tornava peça chave na integração de figuras como Schwanda às redes internacionais de comércio de espécimes que conectavam instituições científicas, revendedores e coletores espalhados pelo mundo. É por meio dessas redes de comércio de espécimes que os museus conseguiam obter os artefatos necessários às suas atividades científicas e expositivas; e são elas, igualmente, que viabilizavam a atuação de caçadores como Ferdinand Schwanda em diversas partes do mundo.

Com seu quadro funcional um tanto enxuto para enfrentar todos os obstáculos envolvidos na coleta de espécimes científicos, O Museu Paulista encontrou na compra desses materiais uma solução para complementar suas coleções de História Natural. Comprar espécimes tanto de caçadores atuantes no Brasil quanto de revendedores na Europa foi o modo encontrado pelo Museu para que seus acervos abrangessem um território continental e possuíssem materiais difíceis de serem obtidos. Só assim tornavam-se factíveis as agendas de pesquisa e os projetos expositivos do Museu (sobre os quais trataremos nos capítulos seguintes desta dissertação). Mas, mais do que apenas comprar espécimes, o Museu exerceu um papel ativo no âmbito dessas redes internacionais de comércio de produtos de História Natural.

Ihering, ao intermediar contatos entre revendedores e caçadores, ao fazer essas gentilezas, garantia não apenas bons interlocutores que poderiam futuramente Ihe retribuir favores; assegurava também a própria existência de um mercado para os produtos de História Natural.

A partir da leitura dos documentos, pode-se entender que o Museu Paulista agia como fomentador do trabalho de caçadores residentes no país. Atuava inclusive 
direcionando a ação dos coletores, ensinando-lhes os métodos de preparação que a instituição considerava apropriados, os quais deviam ser os mesmos aceitos pelos compradores estrangeiros. No trecho anteriormente citado do relatório escrito por Rodolpho von Ihering, dizia ele acerca dos caçadores dos quais o Museu comprava espécimes: “(...) ensinados pelo nosso preparador já agora nos preparam bons couros ou conservam os animais em álcool e assim constantemente lhes compramos bom material." ${ }^{\text {146 }}$

Como vimos acima, o pesquisador americano interessado em pumas dava instruções específicas sobre os procedimentos de preparação dos espécimes. Já o negociante francês Le Moult, como vimos, fazia questão de propagandear que seus espécimes vinham com etiquetas indicando o local de origem exato de cada peça. Ihering parecia agir junto aos coletores e negociantes atuantes no Brasil de modo a garantir que o material por eles produzido estivesse de acordo com essas exigências dos compradores europeus. O próprio Schwanda nos faz saber, conforme trecho já citado, que o diretor lhe fazia exigências quanto ao modo de preparação dos couros, solicitando que fosse feita "com sal e alúmen". ${ }^{147}$

O Museu Paulista atuava no âmago dessa rede de relações, cuja constituição - à medida que servia para aumentar as coleções da instituição - também era passo fundamental para que ele se afirmasse enquanto espaço de produção e veiculação de conhecimentos sobre a fauna do país. Para a construção dos conhecimentos sobre a natureza brasileira, eram necessários espécimes; e para a construção desses objetos eram necessárias diversas práticas, a primeira delas sendo a coleta do material bruto (a caça de animais); e para viabilizar tais práticas era necessário construir relações com caçadores atuantes no Brasil e negociantes sediados na Europa.

Portanto, essa rede comercial costurada pelo Museu, ao interligar coletores residentes no Brasil a casas comerciais sediadas na Europa, fomentava a profissionalização dos coletores autônomos atuantes no país. Fomentava enfim a própria oferta de espécimes, o que possibilitou ao Museu superar os obstáculos

\footnotetext{
${ }^{146}$ IHERING, Rodolpho von. O Museu Paulista nos annos de 1903 a 1905. Revista do Museu Paulista, 7,1907, pp. 9-10.

${ }^{147}$ CARTA de Ferdinand Schwanda, Miritiba, 16/07/1910. APMP/FMP, Série Correspondência.
} 
envolvidos na aquisição desses objetos por meio dos quais eram produzidos e veiculados conhecimentos sobre a natureza sul-americana. 


\title{
2. Estudos científicos
}

Em 1898, oficiando à Secretaria do Interior (repartição à qual se subordinava o Museu Paulista), Ihering procurou conseguir autorização para adquirir espécimes de aves do negociante alemão Hermann Rolle:

\begin{abstract}
Preparando publicação completa sobre Aves do E. de S. Paulo e precisando de completar nossa coleção de pássaros do Brasil meridional e sendo difícil visto não se ter encontrado diversos exemplares, peço-vos autorização para mandar vir da Casa H. Rolle uma coleção de couros de pássaro para serem escolhidos os espécimes que precisamos; isto no valor de 300 Ms [300 marcos]. ${ }^{148}$
\end{abstract}

Como vemos, o argumento empregado pelo diretor do Museu para convencer seu superior a autorizar o referido gasto com a compra de espécimes é a necessidade de completar a coleção de pássaros do Museu e, assim, conseguir empreender um estudo completo sobre as aves do estado de São Paulo.

Conforme visto no capítulo anterior, para formar suas coleções, o Museu Paulista lançava mão de algumas estratégias. Além de ter um naturalista viajante quase sempre em campo, o Museu recorria à compra de espécimes na Europa e no Brasil. A atuação do Museu Paulista no âmbito de uma rede internacional de comércio de produtos de História Natural possibilitou à instituição a complementação de suas coleções, viabilizando assim a produção de estudos sobre a natureza nacional.

Embora já tenhamos indicado diversas vezes a importância das coleções do Museu para a produção de conhecimentos, ainda se faz necessário compreender que conhecimentos eram esses e como os espécimes eram utilizados em seu desenvolvimento.

Neste capítulo, procuraremos entender, por meio do exame dos trabalhos zoológicos veiculados na Revista do Museu Paulista, que estudos eram esses e que uso faziam das coleções do Museu. Objetiva-se, sobretudo, compreender como os espécimes científicos do Museu eram mobilizados para produção de conhecimento e

${ }^{148}$ Ofíclo ao Secretário do Interior, São Paulo, 20/07/1898. APMP/FMP, Série Correspondência. 
como determinadas necessidades em relação ao uso de coleções (como a existência de séries de animais provenientes de diversas regiões do estado e do país) impactavam os processos de aquisição de acervo. Para tanto, será necessário, primeiramente, caracterizar essas publicações da instituição e os estudos zoológicos nela veiculados. Só então será possível analisar como os espécimes científicos das coleções do Museu eram empregados nesses estudos.

Como veremos, entre os trabalhos zoológicos, predominavam os estudos de caráter taxonômico, destinados a inventariar os diferentes grupos animais ocorrentes em território paulista e brasileiro. Nossa atenção recairá, por isso, sobre esses trabalhos de Sistemática, que serão caracterizados e analisados no que se refere a seus objetivos e ao modo como empregam materiais das coleções do Museu.

Sendo assim, este capítulo trará, primeiramente, uma caracterização da Revista do Museu Paulista e de seus artigos zoológicos. Em seguida, trataremos dos trabalhos de Sistemática, que serão caracterizados e terão suas finalidades examinadas. Por fim, discutiremos os modos como os espécimes do Museu eram empregados nos trabalhos taxonômicos da instituição e como tais usos refletem nos procedimentos de aquisição de coleções.

\subsection{As publicações do Museu Paulista}

No período que corresponde à gestão de Hermann von Ihering, foram publicados nove volumes da Revista do Museu Paulista. Tratava-se, principalmente, de um periódico destinado à veiculação dos estudos científicos desenvolvidos no âmbito da instituição - aí entendidos tanto os trabalhos dos pesquisadores da casa quanto aqueles, embora feitos por cientistas externos ao Museu, realizados com base em seu acervo. ${ }^{149}$

Além de suporte para a interlocução científica, a Revista funcionava como uma espécie de cartão de visitas, instrumento de afirmação da instituição recém-

\footnotetext{
${ }^{149}$ Sobre as revistas científicas institucionais que circulavam em São Paulo entre o final do século XIX e princípio do XX, ver MARTINS, Ana Luiza, op. cit., 2001, pp. 324-339.
} 
criada no universo dos museus de História Natural estrangeiros. Servia ainda de moeda de troca na permuta com publicações de outras instituições.

Lopes e, posteriormente, Gualtieri contabilizaram o número de artigos dos nove primeiros volumes da Revista dedicados a cada área do conhecimento, ambas apontando a predominância da Zoologia entre as áreas às quais se vinculam esses trabalhos. ${ }^{150}$

Esses estudos de Zoologia possuíam um caráter abrangente, tendo sido veiculados artigos acerca de diversos grupos do reino animal (moluscos, crustáceos, vermes, insetos, peixes, anfíbios, répteis, aves e mamíferos). Além disso diferentemente dos estudos veiculados pelos Archivos do Museu Nacional -, tais trabalhos, na maioria das vezes, não versavam sobre aspectos muito pontais. ${ }^{151}$ Ao contrário, como veremos, boa parte deles se dedica a inventariar grupos da fauna paulista e brasileira.

Entre os 76 artigos que tratam de Zoologia e Botânica, a maior parte é dedicada a insetos (46\%), aves (9\%), moluscos (7\%) e peixes (7\%). ${ }^{152}$ Gualtieri explica a predominância dos insetos como reflexo do interesse do Museu pela Entomologia Econômica (estudos sobre pragas agrícolas). Mas cabe ressalvar que parte desses trabalhos sobre insetos não são propriamente de Entomologia Econômica, mas de Sistemática - como os catálogos de abelhas solitárias e vespas sociais. ${ }^{153}$

\footnotetext{
150 Embora não adotem critérios idênticos de agrupamento, o que torna os resultados finais ligeiramente diferentes, ambas apontam a Zoologia como área à qual se filiam mais da metade dos artigos. Conforme Lopes, entre os 128 artigos contabilizados: 55\% tratam de Zoologia e Paleozoologia; $11 \%$ de Etnografia e Arqueologia; 8,6\% consistem em informações sobre o Museu; $12,5 \%$ em listas de intercâmbios bibliográficos e bibliografias comentadas; $5,5 \%$ em biografias e necrológios; 3,1\% tratam de Botânica; $1,5 \%$ de Geografia; $1,5 \%$ de viagens; $0,7 \%$ de Geologia e $0,7 \%$ de História. De acordo com Gualtieri, contam-se 121 artigos assim divididos: $61 \%$ tratam de Zoologia; $8 \%$ de Paleontologia/Geologia; $11 \%$ de Antropologia/Arqueologia; $1 \%$ de Botânica e 19\% de outros assuntos. LOPES, Maria Margaret, op. cit., 1997, p. 284. GUALTIERI, Regina Cândida Ellero, op. cit., 2008, p. 105. Schwarcz também contabiliza os artigos por área de conhecimento, mas abrange um período maior que aquele correspondente à gestão Ihering. SCHWARCZ, Lilia Moritz, op. cit., 1993, p. 81.

${ }^{151}$ GUALTIERI, Regina Cândida Ellero, op. cit., 2008, p. 19

152 Ibidem, pp. 107-110

153 SCHROTTKY, Curt. Ensaio sobre as Abelhas solitarias do Brazil. Revista do Museu Paulista, 5, 1902, pp. 330-613. IHERING, Rodolpho von. As vespas sociaes do Brazil. Revista do Museu Paulista, 6, 1904, pp. 97-309.
} 
Ainda segundo Gualtieri, os demais grupos priorizados (aves, moluscos e peixes) constituíam as especialidades de Hermann e Rodolpho von Ihering. ${ }^{154}$ Conforme Lopes já havia notado, a Revista era claramente um veículo para a produção zoológica de Hermann von Ihering, particularmente dos estudos de Sistemática e Zoogeografia. ${ }^{155}$ De fato, Hermann e Rodolpho von Ihering foram responsáveis pela maior parte dos artigos publicados: dos 75 trabalhos zoológicos por nós contabilizados, 24 são de autoria do primeiro e 16 do segundo. Isso pode ser explicado pelo fato de o Museu ter um estafe científico bastante enxuto: o diretor, um zelador (curador), um naturalista viajante e, em alguns momentos, um entomólogo. ${ }^{156}$

Esses trabalhos zoológicos publicados na Revista vinculam-se aos principais campos de interesse da Zoologia do período: Sistemática, Biogeografia e Biologia. A Taxonomia ou Sistemática se ocupava da descrição, nomenclatura e classificação dos organismos vivos. A Biogeografia tratava da distribuição dos seres vivos pelo Planeta, demonstrando dessa forma as relações de parentesco (evolutivas) entre as espécies. A Biologia, no sentido restrito como o termo era empregado na segunda metade do século XIX, ocupava-se das formas de vida de animais e plantas (temas como nidificação dos pássaros ou metamorfose dos insetos, por exemplo, eram caros à Biologia). Já a Ecologia - que aparece de forma mais incipiente na Revista estudava a relação entre os organismos e seu meio. Ressalte-se, todavia, que as fronteiras entre Biogeografia, Biologia e Ecologia eram por vezes porosas. ${ }^{157}$

Dentre esses campos, predominavam na Revista os trabalhos de Sistemática: dos 75 artigos dedicados à Zoologia por nós contabilizados, 59 tratam de Sistemática, 11 de Zoogeografia e 13 de Biologia. Além disso, 8 trabalhos possuem caráter nitidamente aplicado, na maior parte estudos de Entomologia Econômica ver Apêndice E. ${ }^{158}$

\footnotetext{
${ }^{154}$ GUALTIERI, Regina Cândida Ellero, op. cit., 2008, p. 110.

155 LOPES, Maria Margaret, op. cit., 1997, pp. 282-285.

${ }^{156}$ Sobre as atribuições do cargo de zelador ou custos, ver nota 52.

${ }_{157}$ Ver KösteRING, Susanne, op. cit., 2003, pp. 75-131.

$158 \mathrm{Um}$ mesmo artigo pode abordar mais de uma das especialidades em questão. Consideramos como trabalhos que abordam Zoogeografia aqueles que efetivamente procuram tratar da definição de zonas biogeográficas. A mera referência a locais de ocorrência das espécies no interior de trabalhos sistemáticos não foi considerada aqui como suficiente para caracterizar um trabalho como de cunho zoogeográfico.
} 
Parte considerável desses trabalhos zoológicos emprega coleções para sua fatura: 55 do total de 75. Desses 55, 37 empregam coleções pertencentes ao Museu Paulista. Outros trabalhos baseiam-se somente na literatura, ou então em observações de campo e, em um caso, em experimentação - ver Apêndice E.

Como vemos, a maior parte dos trabalhos zoológicos trata de Sistemática e emprega espécimes científicos como instrumentos de pesquisa (na maioria das vezes, espécimes pertencentes às coleções do Museu Paulista). Veremos então, nas próximas seções, qual o caráter desses trabalhos sistemáticos e como eles mobilizam os espécimes científicos para sua fatura. ${ }^{159}$

\subsection{Catalogação da fauna nacional}

Os estudos de caráter taxonômico constituíam parte fundamental dos trabalhos científicos desenvolvidos pelo Museu Paulista. Esses trabalhos, que visavam contribuir para o inventário da fauna brasileira, eram recorrentes nas publicações da instituição. Optamos por dividir tais estudos de Sistemática publicados na Revista em cinco categorias: catálogos (15 trabalhos); complementos (6); revisões taxonômicas (8); descrições de espécies novas (16); e identificações por encomenda (13) - ver o Apêndice E.

Os catálogos eram trabalhos catalográficos de síntese, visando arrolar todas as espécies pertencentes à determinada classe, ordem ou família ocorrentes em

\footnotetext{
159 Além da Revista, o Museu publicou quatro volumes da série intitulada Catalogos da Fauna Brazileira. Eram trabalhos de Sistemática que visavam arrolar todas as espécies de determinados táxons. São, portanto, trabalhos da mesma categoria dos estudos catalográficos publicados na Revista, dos quais trataremos mais à frente - dois dos volumes da série (dedicados a miriápodes e coccídeos) são, inclusive, atualizações de trabalhos anteriores publicados na própria Revista. Quando necessário, os trabalhos dessa coleção serão referidos nesta dissertação; todavia, em nossas contagens incluímos apenas os artigos da Revista, já que ela era o principal veículo de difusão dos trabalhos da instituição. Os seguintes volumes foram publicados como parte da série: IHERING, Hermann von; IHERING, Rodolpho von. As aves do Brasil. São Paulo: Typographia do Diario Official, 1907 (Catalogos da Fauna Brazileira, 1); BrölemanN, H. Os Myriapodos do Brazil. São Paulo: Cardozo, Filho e C., 1909 (Catalogos da Fauna Brazileira, 2); HEMPEL, Adolph. As coccidas do Brazil. São Paulo: Typographia do Diario Official, 1912 (Catalogos da Fauna Brazileira, 3); e DuCKE, Adolpho. As Chrysididas do Brazil. São Paulo: Typographia do Diario Official, 1913 (Catalogos da Fauna Brazileira, 4).
} 
uma circunscrição territorial (geralmente o território do estado de São Paulo ou do Brasil).

Nos catálogos, as entradas são feitas pelo nome científico da espécie. Em seguida são apresentadas, na maioria dos casos: as sinonímias (isto é, outros nomes de espécies que na verdade correspondem à mesma espécie que está ali sendo descrita) com a respectiva literatura (os trabalhos científicos que se referem àquela nomenclatura); descrição dos caracteres anatômicos que permitem a individualização daquela espécie; indicação das regiões de ocorrência da espécie; e, em alguns casos, considerações sobre a biologia da espécie.

Aparecem também, na maioria dos casos, referências a exemplares daquela espécie existentes na coleção do Museu Paulista. Tais referências podem ser apenas a indicação da posse de um exemplar e sua localidade de proveniência, como no catálogo das aves, ou então um trabalho mais detalhado, apresentando, além do local de proveniência, descrições e medidas do espécime, como no caso do catálogo de mamíferos (carnívoros). ${ }^{160}$ Mais à frente trataremos de como essas referências menos ou mais complexas aos espécimes da coleção do Museu Paulista dizem respeito a formas diferentes de mobilizá-los para produzir conhecimento.

Importante ressaltar que tais estudos não consistiam em catálogos das coleções do Museu, mas sim em trabalhos compilatórios que visavam reunir informações sobre a fauna regional, empregando para sua fatura a literatura já existente e, de forma mais profunda ou menos (como veremos), espécimes das coleções do Museu Paulista. Segundo o próprio Ihering em um desses trabalhos: "O presente artigo não pretende ser um catálogo da coleção ornitológica do Museu Paulista, mas sim uma sinopse de tudo que até hoje consta da literatura e das coleções do Museu sobre as aves de S. Paulo". 161

Entre os trabalhos catalográficos amplos, podemos citar: os catálogos de mamíferos do Brasil meridional (carnívoros), das aves paulistas, das aves brasileiras (volume 1 da coleção Catalogos da Fauna Brazileira), das aves do Paraguai, das

\footnotetext{
160 IHERING, Hermann von. As aves do Estado de S. Paulo. Revista do Museu Paulista, 3, 1898, pp. 113-476. IHERING, Hermann von. Os mammiferos do Brazil Meridional: I Contribuição: Carnivora. Revista do Museu Paulista, 8, 1911, pp. 147-272.

${ }_{161}$ IHERING, Hermann von. As aves do Estado de S. Paulo. Revista do Museu Paulista, 3, 1898, p. 113.
} 
aranhas de São Paulo, dos coccídeos brasileiros, das abelhas solitárias brasileiras, das vespas sociais brasileiras, dos peixes de água doce brasileiros, das cobras brasileiras e dos camarões de água doce sul-americanos. ${ }^{162}$

Tais catálogos eram muitas vezes seguidos de complementos publicados posteriormente: artigos destinados à sua atualização/retificação. Entre as publicações posteriores destinadas a complementar e/ou retificar alguns desses catálogos, podemos mencionar os adendos ao catálogo de aves do estado de São Paulo. Tais trabalhos posteriores aglutinavam, sob um mesmo artigo, além de complementações ao inventário das aves paulistas (acrescentavam ou excluíam espécies no rol daquelas ocorrentes no estado de São Paulo), considerações de caráter biológico ou zoogeográfico. ${ }^{163}$ Já o catálogo das abelhas solitárias é complementado por artigo de Schrottky, no qual arrola as espécies de um gênero sobre o qual não havia se detido no catálogo. ${ }^{164}$

Além dos trabalhos catalográficos amplos e seus complementos, publicações cujo objetivo primordial é alinhavar todas as espécies ocorrentes em determinada circunscrição territorial, existiam estudos de recorte mais circunscrito, que dividimos em trabalhos de revisão taxonômica, descrição de espécies novas e identificação por encomenda.

\footnotetext{
162 IHERING, Hermann von. Os mammiferos do Brazil Meridional: I Contribuição: Carnivora. Revista do Museu Paulista, 8, 1911, pp. 147-272. IHERING, Hermann von. As aves do Estado de S. Paulo. Revista do Museu Paulista, 3, 1898, pp. 113-476. IHERING, Hermann von; IHERING, Rodolpho von. As aves do Brasil. São Paulo: Typographia do Diario Official, 1907 (Catalogos da Fauna Brazileira, 1). MoEnKHAUS, W. J. Contribuição para o conhecimento das aranhas de S. Paulo. Revista do Museu Paulista, 3, 1898, pp. 77-112. HeMPEL, Adolph. As Coccidas brazileiras. Revista do Museu Paulista, 4, 1900, pp. 365-537. SCHROTTKY, Curt. Ensaio sobre as Abelhas solitarias do Brazil. Revista do Museu Paulista, 5, 1902, pp. 330-613. IHERING, Rodolpho von. As vespas sociaes do Brazil. Revista do Museu Paulista, 6, 1904, pp. 97-309. IHERING, Rodolpho von. Os Peixes da agua doce do Brazil. Revista do Museu Paulista, 7, 1907, pp. 258-336. IHERING, Rodolpho von. As cobras do Brazil. Revista do Museu Paulista, 8, 1911, pp. 273-379. OrtmAnN, Arnold E. Os camarões da agua doce da America do Sul. Revista do Museu Paulista, 2, 1897, pp. 173-216. O catálogo de coccídeos de Hempel foi atualizado, alguns anos depois do artigo publicado na Revista, por outra publicação do Museu Paulista, também de autoria de Hempel. Ver HEMPEL, Adolph. As coccidas do Brazil. São Paulo: Typographia do Diario Official, 1912 (Catalogos da Fauna Brazileira, 3).

${ }^{163}$ Ver IHERING, Hermann von. As aves do Estado de S. Paulo. Revista do Museu Paulista, 3, 1898, pp. 113-476. IHERING, Hermann von. Contribuições para o conhecimento da Ornithologia de S. Paulo. Revista do Museu Paulista, 5, 1902, pp. 261-329. IHERING, Hermann von. As aves do Paraguay em comparação com as de S. Paulo. Revista do Museu Paulista, 6, 1904, pp. 310-384. IHERING, Hermann von. Novas contribuições para a Ornithologia do Brazil. Revista do Museu Paulista, 9, 1914, pp. 411488.

${ }^{164}$ SCHROTTKY, Curt. As espécies brazileiras do gen. Megachile (Hymenopt.), como supplemento ao «Ensaio das Abelhas solitárias do Brazil ». Revista do Museu Paulista, 9, 1914, pp. 134-223.
} 
As revisões taxonômicas objetivavam primordialmente detectar sinonímias e rever a posição taxonômica das espécies de determinado gênero ou família. Podemos citar como exemplos os artigos sobre os bugios do gênero Alouatta, sobre gambás do Brasil, sobre as cuculidas brasileiras (família de aves) e sobre os caracóis do gênero Solaropsis. ${ }^{165}$

Já as descrições de espécies novas dedicavam-se a nomear e descrever espécies consideradas novas para a ciência, isto é, até então não nomeadas nem descritas formalmente em nenhum trabalho científico. Podemos citar o artigo de Schrottky, que traz a descrição de 20 novas espécies de abelhas brasileiras (principalmente de São Paulo) e mais algumas paraguaias, com base em material do Museu Paulista (e também, em pouquíssimos casos, em material da coleção pessoal do autor). ${ }^{166}$ Rodolpho von Ihering também publica artigos destinados especificamente a descrever novas espécies de peixes de água doce e vespas solitárias. ${ }^{167}$ Vale ressaltar que tais contribuições ao inventário da fauna nacional também podem ser consideradas complementos de catálogos anteriores, como, no caso dos peixes, o catálogo de peixes de água doce publicado pelo mesmo Rodolpho von Ihering. ${ }^{168}$

As identificações por encomenda, por sua vez, consistem, na maioria dos casos, em contribuições de especialistas estrangeiros dedicadas especificamente a identificar conjuntos de espécimes, pertencentes ao Museu Paulista, remetidos por Ihering para esse fim específico. Nesses casos, as publicações consistem em listas com identificação das espécies às quais pertencem os materiais enviados, com ligeiras descrições. No caso de existirem espécies novas entre o material remetido, essas são descritas com mais detalhe.

\footnotetext{
${ }^{165}$ IHERING, Hermann von. Os bugios do genero Alouatta. Revista do Museu Paulista, 9, 1914, pp. 231-280. IHERING, Hermann von. Os Gambás do Brazil: Marsupiaes do gen. Didelphis. Revista do Museu Paulista, 9, 1914, pp. 338-356. IHERING, Hermann von. Biologia e classificação das Cuculidas brazileiras. Revista do Museu Paulista, 9, 1914, pp. 371-410. IHERING, Hermann von. Os Caracóes do genero Solaropsis. Revista do Museu Paulista, 4, 1900, pp. 539-549. Nesta dissertação, os termos utilizados para designação de espécies e demais táxons são aqueles empregados nos estudos dos quais foram extraídos, não correspondendo necessariamente às nomenclaturas hoje aceitas.

${ }^{166} \mathrm{Na}$ segunda parte, o artigo traz informações sobre a localidade de proveniência de outros espécimes de abelhas da coleção do Museu Paulista. ScHROTTKY, Curt. Descripção de abelhas novas do Brazil e de regiões visinhas. Revista do Museu Paulista, 8, 1911, pp. 71-88.

167 IHERING, Rodolpho von. Algumas especies novas de peixes d'agua doce. Revista do Museu Paulista, 8, 1911, pp. 380-413. IHERING, Rodolpho von. Algumas especies novas de Vespas solitárias. Revista do Museu Paulista, 8, 1911, pp. 462-475.

168 IHERING, Rodolpho von. IHERING, Rodolpho von. Os Peixes da agua doce do Brazil. Revista do Museu Paulista, 7, 1907, pp. 258-336.
} 
Entre as identificações por encomenda, podemos citar contribuições como as de Eigennann e Norris (identificação de espécimes de peixes), Weise (sobre família de besouros), e o longo trabalho de Brölemann com a coleção de miriápodes do Museu Paulista, no qual inclusive descreve diversas novas espécies. ${ }^{169}$

Todas essas categorias de estudos consistiam em contribuições para uma agenda de trabalho voltada para o inventário da fauna nacional. Esses diferentes escopos atribuídos a cada uma das categorias devem ser entendidos mais como uma questão de intensidade do que de caráter: embora o objetivo principal dos catálogos seja reunir descrições de todas as espécies ocorrentes em determinada circunscrição regional, eles por vezes também se dedicam a refinar o conhecimento taxonômico proveniente da literatura e a descrever espécies novas. Por exemplo, os catálogos de coccídeos (escrito por Hempel), de aranhas de São Paulo (de Moenkhaus) ou o de abelhas solitárias (de Schrottky), incluem a descrição de novas espécies. $^{170}$

De certa forma, essas diferentes categorias também estavam atreladas aos grupos animais estudados. No caso da Ornitologia ou da Mastozoologia, por exemplo, que já vinham sendo de longa data objeto de trabalho de naturalistas, tratava-se menos de descobrir espécies novas do que de consolidar a literatura existente e revisar a taxonomia, para então proceder a análises zoogeográficas e trabalhos de caráter biológico. No caso de outros grupos, o trabalho se encontrava em caráter mais inicial, de modo que a atividade principal ainda era identificar as espécies ocorrentes em território paulista e brasileiro, ou até mesmo descrever espécies novas. Conforme os Ihering:

Há classes para as quais já existem excelentes catálogos, como para os mamíferos, para as aves, coleópteros etc., ao passo que para outras

\footnotetext{
${ }^{169}$ Elgennann, Carl H.; NorRIS, E. Allen A. Sobre alguns Peixes de S. Paulo, Brazil. Revista do Museu Paulista, 4, 1900, pp. 349-362. WEISE, J. Aufzählung von Coccinellen aus dem Museu Paulista. Revista do Museu Paulista, 8, 1911, pp. 54-65. BrölemAnN, H. W. Myriapodes du Musée de S. Paulo. Revista do Museu Paulista, 5, 1902, pp. 35-237.

170 Hempel, Adolph. As Coccidas brazileiras. Revista do Museu Paulista, 4, 1900, pp. 365-537. MoEnkHAUS, W. J. Contribuição para o conhecimento das aranhas de S. Paulo. Revista do Museu Paulista, 3, 1898, pp. 77-112. SCHROTTKY, Curt. Ensaio sobre as Abelhas solitarias do Brazil. Revista do Museu Paulista, 5, 1902, pp. 330-613.
} 
classes ou tipos, mais atrasados no estudo geral de sua nomenclatura, tais auxílios faltam em absoluto. ${ }^{171}$

O catálogo de aranhas publicado por Moenkhaus, por exemplo, intitula-se "Contribuição", já que lista espécies de apenas algumas famílias, descrevendo inclusive sete novas espécies. Não almeja, portanto, ser um inventário regional completo, mas uma contribuição para esse inventário, o qual só poderia ser elaborado quando o estado da arte do conhecimento das aranhas ocorrentes em São Paulo estivesse mais adiantado. ${ }^{172}$

Já o trabalho de Brölemann sobre miriápodes, embora contemple um número grande de espécies, não consiste em um catálogo regional, mas sim na classificação dos espécimes pertencentes à coleção do Museu Paulista - ou seja, um trabalho de identificação por encomenda. Isso deve ser atribuído ao estado da arte do conhecimento sobre os miriápodes. ${ }^{173}$

A elaboração de catálogos pode ser considerada, portanto, o ápice do trabalho de inventário faunístico. Afinal, somente após as espécies já terem sido descritas, e após já se conhecer as espécies ocorrentes em determinado território, é que se podia produzir esses trabalhos sintéticos de referência.

Tais inventários da fauna nacional, ao ampliarem e sintetizarem o conhecimento sobre os animais do país, eram, antes de tudo, um fim em si mesmo. Eram ponto central para a instituição que tinha por objetivo, conforme expresso em seu regulamento, estudar a História Natural da América do Sul, do Brasil e de São Paulo em particular. ${ }^{174}$

\footnotetext{
${ }^{171}$ IHERING, Hermann von; IHERING, Rodolpho von. As aves do Brasil. São Paulo: Typographia do Diario Official, 1907 (Catalogos da Fauna Brazileira, 1), p. II.

172 Ver MOENKHAUS, W. J. Contribuição para o conhecimento das aranhas de S. Paulo. Revista do Museu Paulista, 3, 1898, pp. 77-112.

${ }^{173}$ Segundo Brölemann, o estudo dos miriápodes só havia avançado significativamente havia 20 anos. Quanto aos miriápodes brasileiros, os trabalhos ainda eram bastante escassos. BRÖLEMANN, H. W. Myriapodes du Musée de S. Paulo. Revista do Museu Paulista, 5, 1902, pp. 35-36. Um trabalho catalográfico mais completo dos miriápodes brasileiros, de autoria do próprio Brölemann, foi publicado alguns anos mais tarde pelo Museu Paulista. Ver BrölemANN, H. Os Myriapodos do Brazil. São Paulo: Cardozo, Filho e C., 1909 (Catalogos da Fauna Brazileira, 2).

${ }^{174}$ Ver nota 42 retro.
} 
Mas, para além de serem a concretização de uma das principais finalidades do Museu Paulista, os catálogos se prestavam a algumas outras funções: serviam de base para estudos de Zoologia Aplicada e de Zoogeografia, além de atenderem as necessidades de estudiosos brasileiros (muitas vezes amadores) interessados nos diferentes grupos faunísticos. Vejamos cada uma dessas funções.

Catálogos de grupos prejudiciais à lavoura eram úteis para o desenvolvimento de estudos de Entomologia Econômica. Em seu catálogo dos coccídeos brasileiros, Hempel afirma que, tendo em vista a relevância econômica das espécies do táxon (devido aos fortes danos que poderiam impingir à agricultura de um país), considerava: "(...) de importância reunir e classificar para referência futura todas as notas que se referem ao conhecimento, hábitos e distribuição das coccidas (sic) brasileiras." 175

Os catálogos possibilitavam também o desenvolvimento de estudos zoogeográficos. Os trabalhos catalográficos procuravam, na medida do possível, incluir informações sobre os locais de ocorrência (regiões do estado ou do país, dependendo da abrangência do trabalho) das espécies ali arroladas. Tais dados serviam de base para 0 desenvolvimento de trabalhos comparativos que possibilitavam dividir o território do estado ou do país em diferentes circunscrições zoogeográficas e tecer considerações sobre a gênese das faunas paulista e brasileira.

Em seu catálogo dos peixes de água doce, Rodolpho von Ihering lembra que um conhecimento completo da Sistemática desses animais (incluindo o reconhecimento das relações de descendência entre os diferentes gêneros e famílias), aliado a informações sobre a distribuição geográfica das espécies, poderia subsidiar os estudos que permitiriam delimitar diferentes zonas zoogeográficas no Brasil, bem como aqueles sobre as conexões dos continentes no passado geológico. Conforme o autor:

Mas das próprias relações filogenéticas das ordens ou famílias resultam valiosas informações para deduzirmos daí hipóteses relativas à antiga conexão dos continentes. Especialmente com referência à fauna d'água doce estas documentações nos merecem especial valor, pois que, se há

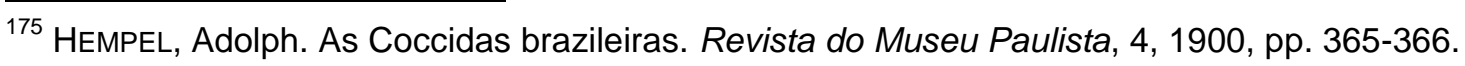


evidente relação de parentesco entre certos gêneros e hoje os encontramos separados por extensos mares de água salgada, que lhes é impossível atravessar, claro está que só podemos concluir que outrora os antecessores desses animais habitavam uma pátria comum e que, com o correr dos tempos, passaram a habitar outras regiões, ao mesmo tempo que, cada qual para o seu lado, sofria modificações mais ou menos acentuadas. ${ }^{176}$

Mas Rodolpho von Ihering pondera que, para desenvolver considerações dessa ordem, seria necessário, primeiro, inventariar todas as espécies ocorrentes em território nacional e conhecer sua distribuição geográfica: "Hoje, como dissemos, em virtude de não nos podermos basear em listas completas, só podemos formular as perguntas; mais tarde será ocasião de estabelecer-se hipóteses e documentálas." 177

As pesquisas desenvolvidas por seu pai, Hermann von Ihering, eram fortemente pautadas pelo interesse em compreender as origens da fauna sulamericana e as conexões existentes entre os atuais continentes no passado geológico. Nesse sentido, o trabalho de inventariar a fauna por meio de catálogos regionais - os quais incluíam informações sobre a distribuição infrarregional de determinado grupo faunístico - era um mecanismo para tentar vislumbrar a distribuição dos diferentes táxons ao longo dos territórios. Assim como o trabalho sistemático com material fóssil (no caso, conchas), esses inventários dos animais viventes eram a base para o desenvolvimento de teorias acerca da gênese da fauna neotrópica e das diferentes configurações dos continentes ao longo do tempo geológico. ${ }^{178}$

Os catálogos serviam ainda como instrumento de trabalho para os estudiosos brasileiros interessados em Sistemática (por exemplo, amadores que pretendessem classificar suas coleções), já que o acesso à literatura internacional era algo complicado. Em seu catálogo das vespas sociais do Brasil, Rodolpho von Ihering faz alguns comentários nesse sentido, afirmando que o inventário, ao reunir toda a

${ }^{176}$ IHERING, Rodolpho von. Os Peixes da agua doce do Brazil. Revista do Museu Paulista, 7, 1907, p. 267.

177 Ibidem, p. 269.

${ }^{178}$ Ver LOPES, Maria Margaret, op. cit., 1997, p. 268; GuALTIERI, Regina Cândida Ellero, op. cit., 2008, pp. 112-113; LOPES, Maria Margaret. Culturas científicas no início do século XIX: um estudo sobre as pontes continentais de Hermann von Ihering (1850-1930). In: SCIENTIARUM HISTORIA - CONGRESSO DE HISTÓRIA DAS CIÊNCIAS E DAS TÉCNICAS E EPISTEMOLOGIA, 4, 2011, Rio de Janeiro. Anais... Rio de Janeiro: Programa de Pós-graduação em História das Ciências e das Técnicas e Epistemologia UFRJ, 2011. 
literatura referente ao assunto, poderia servir aos estudiosos amadores que não tivessem acesso a uma biblioteca especializada. ${ }^{179}$

Já em seu catálogo de peixes de água doce, o mesmo autor afirma de modo semelhante que "(...) os escritos desta série se destinam especialmente ao círculo mais geral dos amadores (...)". ${ }^{180}$ Por esse motivo, em alguns casos, simplificações se faziam necessárias para facilitar o uso desses catálogos por tais leitores. Nesse mesmo catálogo de peixes, Rodolpho von Ihering dispensa o uso de caracteres anatômicos de órgão internos como elemento a ser empregado para classificação das espécies, já que isso requereria do leitor-classificador conhecimentos mais aprofundados de anatomia. ${ }^{181}$

No catálogo de cobras, faz opção semelhante:

Os melhores caracteres para os estudos aprofundados são fornecidos pela anatomia, especialmente pela comparação de certos ossos do crâneo e das vértebras.

Como, porém, quisemos dar com esta nossa monografia um resumo que facilite especialmente ao amador a classificação das cobras do Brasil, evitamos, como aliás o fazemos em todos os nossos resumos desta natureza, todos aqueles característicos (sic) que exijam dissecções ou conhecimentos aprofundados da anatomia especial. ${ }^{182}$

Esse incentivo aos estudiosos amadores, que aparece textualmente algumas vezes na Revista, revela uma preocupação com o público alvo do periódico. De fato, o próprio lhering havia afirmado textualmente que embora fosse interessante que a Revista atingisse também um público não especializado, isso não deveria ser regra:

Desejo quanto mais possível dar a este periódico o caráter de uma publicação de utilidade para todos que se interessam pela exploração científica do país, mas se espero que neste sentido parte dos artigos será de interesse, não poderá assim acontecer com todos, visto que esta publicação não é órgão de instrução popular, mas o arquivo dos resultados obtidos na exploração científica do Brasil pelo pessoal científico desta

\footnotetext{
${ }^{179}$ IHERING, Rodolpho von. As vespas sociaes do Brazil. Revista do Museu Paulista, 6, 1904, p. 97 e p. 220.

180 IHERING, Rodolpho von. Os Peixes da agua doce do Brazil. Revista do Museu Paulista, 7, 1907, p. 260.

181 Ibidem, p. 259.

182 IHERING, Rodolpho von. As cobras do Brazil. Revista do Museu Paulista, 8, 1911, p. 294.
} 
repartição e pelos numerosos especialistas que para os seus estudos recebem materiais coligidos pelos empregados desta repartição. ${ }^{183}$

Embora a Revista conte com alguns artigos acessíveis ao público leigo (como alguns trabalhos sobre a necessidade de preservação da fauna e da flora do país, ou mesmo sobre pragas agrícolas), no geral, abundam trabalhos especializados de sistemática zoológica. Todavia, como vimos, havia uma preocupação em produzir trabalhos que atingissem também cientistas amadores, os quais, embora devessem estar familiarizados com os aspectos essenciais do trabalho zoológico, poderiam carecer de certos conhecimentos mais refinados de anatomia animal.

\subsection{Mobilização das coleções}

O trabalho desenvolvido pelo Museu Paulista em Sistemática não consistia, portanto, apenas em, por meio da literatura, identificar os espécimes que iam sendo incorporados às suas coleções. Ao contrário, pretendia-se (sempre que estado da arte do conhecimento sobre o grupo animal em questão tornava isso possível) compilar o conhecimento existente sobre todas as espécies ocorrentes nas faunas paulista e brasileira. Além disso, procurava-se contribuir para o avanço da ciência zoológica, agregando dados novos ao conhecimento acumulado (dados morfológicos dos espécimes das coleções do Museu) e, em alguns casos, por meio desses dados, refinando a sistemática.

Nesse cenário, os espécimes científicos eram mobilizados de formas mais profundas ou menos. Na maior parte dos catálogos, o uso de espécimes das coleções do Museu parece ser apenas subsidiário. O grosso da informação provém da literatura. No caso do catálogo de aves, por exemplo, na maior parte das espécies descritas, os espécimes das coleções do Museu Paulista apresentam função apenas comprobatória, atestando que a literatura estava correta, que aquela espécie de fato existia em solo paulista. A função do espécime se torna mais importante nos casos em que a literatura não apontava a existência daquela espécie

\footnotetext{
${ }^{183}$ IHERING, Hermann von. O Museu Paulista no anno de 1896. Revista do Museu Paulista, 2, 1897, p. 5.
} 
no território do estado. Nesses casos, o espécime do acervo do Museu atesta uma novidade no conhecimento da avifauna paulista. ${ }^{184}$

Em outros catálogos, os espécimes das coleções do Museu são utilizados de forma um pouco mais profunda. No caso do catálogo de mamíferos do Brasil meridional (carnívoros), por exemplo, são apresentadas informações mais detalhadas sobre exemplares existentes na coleção da instituição. Mesmo assim, o uso dos espécimes fica em segundo plano na maior parte das vezes. Isto é, embora apresente dados morfológicos dos espécimes pertencentes à coleção do Museu (medidas de couros e crâneos), tais dados parecem ser, na maioria das vezes, subsidiários - em relação às informações colhidas na literatura - para atingir o objetivo do artigo (definir quais espécies ocorrem no Brasil meridional e quais são as características dessas espécies). Trata-se, portanto, apenas de agregar informações sobre peculiaridades dos espécimes possuídos pelo Museu Paulista - medidas e coloração de peles diferenciadas, o que poderia indicar variabilidades morfológicas regionais de determinada espécie, não suficientes, todavia, para determinar a existência de uma espécie nova. ${ }^{185}$

É no trabalho de refinamento taxonômico e na descrição de espécies novas que o uso dos espécimes se torna realmente profundo, seja quando isso ocorre nos catálogos, seja nos estudos dedicados especificamente a tais finalidades. A descrição de espécies novas baseia-se, obviamente, no exame morfológico detalhado do espécime. Já no caso do refinamento taxonômico, é a análise comparativa de aspectos da morfologia dos espécimes (cor da pelagem, medidas da pele e do crâneo, etc.), que possibilita revisar o conhecimento presente na literatura.

No trabalho de refinamento taxonômico, seja nos catálogos, seja nos artigos com essa finalidade específica, a posse de espécimes pelo Museu Paulista era então fundamental. Por exemplo, é a posse de espécimes do Paraguai que possibilitou a lhering desenvolver um catálogo das aves paraguaias. Seu trabalho de

\footnotetext{
${ }^{184}$ Ver IHERING, Hermann von. As aves do Estado de S. Paulo. Revista do Museu Paulista, 3, 1898, pp. 113-476.

${ }_{185}$ IHERING, Hermann von. Os mammiferos do Brazil Meridional: I Contribuição: Carnivora. Revista do Museu Paulista, 8, 1911, pp. 147-272.
} 
inventário e revisão taxonômica (detecção de sinonímias) mobilizou, além da literatura, espécimes enviados do Paraguai pelo naturalista Bertoni. ${ }^{186}$

Outro exemplo, retirado do catálogo de mamíferos (carnívoros), é bastante elucidativo. Trata-se do caso da espécie Felis eyra. O fato de Ihering considerá-la como uma espécie - e não como sinonímia de Felis yuaguarundi, gato mourisco, como fizeram outros autores - baseia-se no fato de ter obtido, por meio de sua rede de contatos, um exemplar do animal para as coleções do Museu Paulista. Afinal, tratava-se de um felino algo difícil de ser encontrado. Conforme Ihering: "É este um gato pouco conhecido, que nem Natterer nem Wied, Burmeister, Hensel e Winge não obtiveram." 187 Ainda segundo o autor: "Eu mesmo, em perto de 30 anos de trabalho sobre a fauna do Brasil meridional, só obtive um exemplar de F. eyra para o Museu Paulista, proveniente do Ceará, onde foi colecionado pelo zeloso naturalista sr. Francisco Dias da Rocha, em Fortaleza." 188

Com esse espécime em mãos, Ihering pôde compará-lo com outros seis exemplares de Felis yuaguarundi que possuía o Museu e, com base em diferenças morfológicas (como comprimento da pelagem), concluir pela existência de duas espécies diferentes.

Já os trabalhos cujo objetivo central é a revisão taxonômica, como aqueles sobre os gambás brasileiros ou sobre os bugios do gênero Alouatta, utilizam-se dos espécimes do Museu para confrontar o conhecimento vigente na literatura.

No caso do artigo sobre gambás, as séries de espécimes do Museu Paulista são mobilizadas para refinar o conhecimento taxonômico, já que certas particularidades morfológicas desses animais (seu crescimento ilimitado e sua ampla variabilidade cromática) induziriam 0 naturalista a multiplicar equivocadamente o número de espécies. ${ }^{189}$

No artigo sobre bugios, a importância da posse de espécimes e o modo como eram mobilizados ficam particularmente evidentes. O diretor do Museu inicia seu

\footnotetext{
${ }^{186}$ IHERING, Hermann von. As aves do Paraguay em comparação com as de S. Paulo. Revista do Museu Paulista, 6, 1904, pp. 310-384.

${ }^{187}$ IHERING, Hermann von. Os mammiferos do Brazil Meridional: I Contribuição: Carnivora. Revista do Museu Paulista, 8, 1911, p. 166.

188 Ibidem, p. 167.

189 Ver IHERING, Hermann von. Os Gambás do Brazil: Marsupiaes do gen. Didelphis. Revista do Museu Paulista, 9, 1914, p. 338.
} 
texto evidenciando as lacunas no estudo dos bugios sul-americanos, lacunas que se deviam, segundo ele, às "dificuldades materiais" com que tinham se defrontado até então os naturalistas interessados em estudar o tema em questão:

As poucas espécies de 'bugios' (símios do gênero Alouatta) que habitam a América do Sul e Central ainda não foram até agora bem estudadas, e isto, em boa parte, devido às múltiplas dificuldades materiais com que sempre tiveram de lutar os naturalistas. Mencionaremos apenas o dimorfismo sexual, as diversidades do aspecto das peles determinadas principalmente pelas variantes do colorido conforme o sexo e a idade do exemplar examinado e ainda o número em geral reduzido de espécimes completos de que se dispõe para tal fim. Devido a estas e a outras circunstâncias análogas, ainda nestes últimos anos tem sido descritas pretendidas espécies novas, aumentando assim a confusão. ${ }^{190}$

Como se pode observar, as dificuldades materiais às quais se refere o diretor do Museu Paulista dizem respeito, primeiro, às características físicas dos indivíduos pertencentes ao gênero Alouatta (variação do colorido das peles e de outras características morfológicas em indivíduos pertencentes à mesma espécie); segundo, à falta de material adequado para empreender a análise do gênero (isto é, falta de espécimes completos - peles com crâneos - abrigados em coleções científicas). Sendo assim, somente a disponibilidade de material em condições adequadas e em número suficiente em coleções científicas permitiria uma análise morfológica cuidadosa, a qual possibilitaria ultrapassar o obstáculo das variações morfológicas em indivíduos da mesma espécie, viabilizando assim um trabalho taxonômico correto no que se refere ao gênero Alouatta. Portanto, é a disponibilidade de material no Museu Paulista que possibilitava a Ihering dedicar-se à questão. No que tange particularmente a espécie Alouatta belzebul (que será objeto da primeira parte de seu artigo), afirma ele:

Possuindo o Museu Paulista uma boa série de peles e crâneos desta espécie [Alouatta belzebul L.], coligidos no Maranhão, tive oportunidade de sujeitar a um exame crítico a exposição recentemente publicada pelo Sr. G. Dollman sobre este mesmo assunto. ${ }^{191}$

\footnotetext{
${ }^{190}$ IHERING, Hermann von. Os bugios do genero Alouatta. Revista do Museu Paulista, 9, 1914, p. 231. 191 Ibidem, pp. 231-232. O autor informa ainda que esses espécimes maranhenses foram adquiridos do caçador Ferdinand Schwanda.
} 
Após essa e mais algumas considerações iniciais, a parte primeira do estudo de Ihering prossegue com uma análise minuciosa das colorações de 13 peles de bugios pertencentes à coleção do Museu Paulista, ao que se segue um exame morfológico dos respectivos crâneos. O autor conclui que os 13 espécimes, apesar da variação na cor das peles, pertencem à mesma espécie (Alouatta belzebul) e que tal variação cromática se devia essencialmente às diferenças etárias entre os indivíduos. Desse modo, segundo Ihering, muitas das supostas espécies novas descritas por naturalistas não eram senão descrições de indivíduos de diferentes idades (por isso as variações morfológicas, principalmente quanto à coloração da pelagem), todos pertencentes à mesma espécie - Alouatta belzebul.

Portanto, é por meio do exame das características materiais do espécime científico que o estudo sobre a natureza se tornava possível. É a análise atenta das amostras materiais da natureza (o exame da morfologia de fragmentos de animais) que possibilitava a construção de conhecimentos.

Mesmo nos estudos de caráter biológico, na maioria das vezes eram empregados os métodos dos trabalhos taxonômicos. Ou seja, baseavam-se na formação de coleções, cujas peças eram identificadas, inventariadas e comparadas. No caso dos estudos biológicos sobre aves, por exemplo, eram formadas coleções não de peles, mas sim de ninhos e ovos. $O$ interesse pelo modo de vida das aves se concentrava, portanto, naqueles aspectos que podiam ser estudados por meio de coleções, principalmente os processos de nidificação. O mesmo se dava no caso de estudos sobre a biologia de vespas e abelhas: o tema central eram os processos de nidificação, estudados com base nos ninhos coletados.

Por exemplo, no trabalho sobre as cuculidas, (que trata da Taxonomia, Biologia e Zoogeografia dessa família de aves), são feitas observações em ninhos de saci, Tapera naevia, espécie que, como seus congêneres europeus, deposita seus ovos em ninhos de outras aves. Mas, além das observações de campo, recorre-se à descrição de materiais pertencentes à coleção do Museu Paulista: ninhos da espécie parasitada pelo saci e ovos de saci e da espécie autora do ninho. ${ }^{192}$

\footnotetext{
192 IHERING, Hermann von. Biologia e classificação das Cuculidas brazileiras. Revista do Museu
} Paulista, 9, 1914, pp. 371-410. 
Já no catálogo de vespas sociais brasileiras, na parte que trata da Biologia, recorre-se à literatura e às observações de campo para tratar de tópicos biológicos das vespas (aspectos como nidificação, organização social, fases do desenvolvimento do inseto - ovo, larva, adulto -, entre outros). Mas o processo de nidificação é mais extensivamente estudado por meio da catalogação e descrição dos ninhos (segundo o autor, das 180 espécies de vespas sociais ali arroladas, 54 tinham seus ninhos conhecidos, dos quais o Museu Paulista possuía exemplares de $46) . .^{193}$

Uma vez que os espécimes são os elementos chave para a produção de conhecimentos sobre a fauna do país, era primordial obtê-los, de modo a dotar o Museu de coleções amplas, o que nem sempre era tarefa fácil. Além disso, para que as coleções possibilitassem a confecção de inventários faunísticos e trabalhos de revisão taxonômica, era necessário que elas atendessem determinados requisitos: contemplassem séries de animais (isto é, diversos exemplares da mesma espécie); possuíssem exemplares de diferentes regiões do estado, do país e do continente; apresentassem peças com identificação segura do local de proveniência; e, no caso dos mamíferos, contivessem não apenas peles, mas também crâneos. Era necessário, então, que a política de aquisição de espécimes para as coleções do Museu atentasse para tais requisitos. Vejamos com mais vagar cada uma dessas demandas.

No que se refere à necessidade de coleções amplas, o acervo de Ornitologia nos dá um bom exemplo. Embora Ihering avaliasse - já no início de sua gestão que ela possuía "boa representação das espécies que ocorrem neste Estado", lamentava carecer ainda de material proveniente de zonas mais interioranas, como a região de Franca e o oeste paulista. ${ }^{194}$

Essa ausência de espécimes das regiões mais longínquas do estado poderia comprometer a qualidade dos estudos de Sistemática e Zoogeografia desenvolvidos

\footnotetext{
193 IHERING, Rodolpho von. As vespas sociaes do Brazil. Revista do Museu Paulista, 6, 1904, p. 221.

194 IHERING, Hermann von. As aves do Estado de S. Paulo. Revista do Museu Paulista, 3, 1898, p. 468 e p. 472. IHERING, Hermann von. O Museu Paulista no anno de 1898, Revista do Museu Paulista, 4, 1900 , p. 6.
} 
pelo próprio Ihering a partir das coleções do Museu. O problema iria sendo sanado com o passar dos anos, conforme o naturalista viajante fosse realizando expedições em regiões mais interioranas e a rede de contatos do museu fosse frutificando. Espécimes da região de Franca, por exemplo, foram comprados do caçador Otto Dreher entre 1902 e 1903, conforme atestam diversas contas existentes no arquivo do Museu Paulista.

Desse modo - conforme afirmou Ihering alguns anos mais tarde -, o conhecimento da avifauna do estado alcançaria um estágio bastante avançado, a ponto de poder ser considerado, segundo o diretor, o mais completo entre os estados do Brasil - conhecimento não só das espécies ocorrentes no território do estado, como de sua distribuição, geografia e biologia. ${ }^{195}$

Anos mais tarde, em artigo publicado em 1914, o diretor se vangloriaria da coleção ornitológica do Museu de forma ainda mais explícita. Segundo Ihering, o Museu estava à altura, em termos de aves brasileiras, das grandes coleções europeias - como as dos museus de Londres, Munique, Viena e Paris, e as coleções particulares de von Rothscild e do conde von Berlepsch, as quais, segundo Ihering, eram "enormemente ricas em espécie brasileiras". 196

Ainda no mesmo artigo, afirma o diretor que a coleção de estudos do Museu contava então com 6.587 espécimes (couros) de aves, aos quais se somavam outros 1.000 na coleção exposta ao público. Das 1.801 espécies e subespécies brasileiras, a coleção do Museu contava com representantes de 1.238. A seção ornitológica continha também expressivas coleções de ninhos e ovos de aves brasileiras, sendo essas, conforme Ihering, talvez as mais ricas do mundo. ${ }^{197}$

Essas coleções de estudos da área de Ornitologia eram abrigadas numa sala do andar térreo, sendo as peles acondicionadas em "dez armários duplos, de 34 ou 36 gavetas cada um, e as tampas destas gavetas, providas de encaixe com macho e fêmea, fecham por assim dizer hermeticamente", além de "28 caixas grandes, igualmente bem fechadas, que contêm os couros das grandes aves". Havia ainda a

\footnotetext{
195 IHERING, Hermann von. As aves do Paraguay em comparação com as de S. Paulo. Revista do Museu Paulista, 6, 1904, p. 364.

${ }^{196}$ IHERING, Hermann von. Novas contribuições para a Ornithologia do Brazil. Revista do Museu Paulista, 9, 1914, pp. 412-413.

197 IHERING, Hermann von. Novas contribuições para a Ornithologia do Brazil. Revista do Museu Paulista, 9, 1914, p. 413 e p. 417.
} 
coleção de ninhos e outros quatro armários que abrigavam a coleção de ovos. Assim, segundo Ihering: "O acondicionamento e a conservação [das coleções ornitológicas de estudo do Museu] podem ser considerados perfeitos."198

Ampliar dessa forma o volume das coleções do Museu era fundamental, uma vez que para o desenvolvimento dos trabalhos de revisão taxonômica se fazia necessária a posse de séries de animais, isto é, de diversos espécimes da mesma espécie. Só assim era possível observar as variações ocorrentes no âmbito de indivíduos da mesma espécie.

Ihering aponta, por exemplo, como o naturalista Hensel acabou indicando equivocadamente a existência de uma nova espécie de felino devido ao fato de ter examinado poucos exemplares. Segundo o diretor, se o naturalista tivesse analisado um número maior de indivíduos, não teria nomeado uma nova espécie somente com base em variações na dentição que ocorriam entre os membros da espécie. Segundo Ihering:

\begin{abstract}
Hensel, pouco feliz no estudo do material insuficiente que teve desta espécie, denominou $\mathrm{F}$. guigna os três crâneos aos quais falta o primeiro pré-molar superior, criando uma nova espécie, F. guttula, para os exemplares cujos crâneos tinham estes dentes bem desenvolvidos. Se Hensel tivesse tido material tão rico deste grupo como eu e Winge, certamente não teria cometido o erro de descrever uma nova espécie de gato baseado em diferença tão pequena, quando se vê, pela comparação de séries grandes, que mesmo os caracteres essenciais de couro e crâneo variam amplamente. ${ }^{199}$
\end{abstract}

Ihering deixa essa questão da importância da posse de séries ainda mais clara na introdução do catálogo de mamíferos (carnívoros). Ali, o autor afirma que a

\footnotetext{
198 Ibidem, pp. 413-414. Os armários utilizados para acondicionar as coleções de estudos do Museu (ao menos as ornitológicas e entomológicas) eram importados da Alemanha. Eram fabricados pela oficina de carpintaria de Richard Ihle ("Richard Ihle, Tischlermeister"), empreendimento especializado na produção de mobiliário para coleções zoológicas. Em alguns momentos, Ihering precisou justificar aos seus superiores a necessidade de importar tais móveis ao invés de adquiri-los no Brasil, sob o argumento de que se tratava de armários especiais, indisponíveis no Brasil, cujas tampas das gavetas deveriam fechar hermeticamente (para impedir a entrada de insetos que pudessem atacar os espécimes, supomos). Ofíclos [de Hermann von Ihering] ao Secretário do Interior, São Paulo, 29/04/1898 e 26/07/1901. APMP/FMP, Série Correspondência; CONTA de Richard Ihle, Tischlermeister, referente a oito armários para insetos, Dresden, 29/11/1906. APMP/FMP, Série Prestações de contas.

${ }^{199}$ IHERING, Hermann von. Os mammiferos do Brazil Meridional: I Contribuição: Carnivora. Revista do Museu Paulista, 8, 1911, p. 189.
} 
falta de séries (particularmente de exemplares "do noroeste e do sertão central do Brasil") impedia um trabalho apurado no que se refere à definição das características das espécies; o que explicaria "os graves erros cometidos por especialistas de competência geralmente reconhecida”. ${ }^{200}$ Afirma então que a aquisição de espécimes pelo Museu Paulista permitiu à instituição reunir séries que possibilitavam um trabalho apurado de classificação, capaz de reconhecer as variabilidades morfológicas ocorrentes dentro da mesma espécie:

\begin{abstract}
O Museu Paulista, graças aos esforços de seus ativos naturalistas viajantes reuniu sucessivamente, além das coleções expostas ao público, valiosíssimas séries de couros de mamíferos, todos acompanhados do respectivo crâneo. Deste modo nos é possível não só comparar representantes do mesmo gênero ou da mesma espécie provenientes de localidades diferentes, mas também, estudar, pelo exame de numerosos indivíduos da mesma proveniência, a variabilidade de cada espécie segundo idade, sexo, época de ano etc. ${ }^{201}$
\end{abstract}

Em seu catálogo das aves do Brasil, o autor também aponta a necessidade de consultar séries com diversos exemplares da mesma espécie provenientes de localidades variadas e de idade, plumagem e sexo diferentes. Afirma ainda que o importante ornitólogo austríaco Hellmayr, para dirimir certas dúvidas de classificação, por vezes examinava: “(...) nada menos de 120 ou 160 exemplares da mesma espécie ou subespécie, para o que compara os materiais de diversos Museus, não trepidando mesmo em fazer viagens às diversas capitais europeias $(\ldots)$ ".. 202

Daí a importância de, além de um naturalista viajante, ter uma rede de coletores que pudessem fornecer ao Museu Paulista espécimes provenientes das diversas regiões do país e da América do Sul. ${ }^{203}$ Afinal, essas séries deveriam contemplar não apenas animais provenientes de uma mesma região (o que também era importante, tendo em vista a necessidade de verificar variabilidades morfológicas

\footnotetext{
${ }^{200}$ Ibidem, pp. 147-148.

${ }^{201}$ Ibidem, p. 148.

202 IHERING, Hermann von; IHERING, Rodolpho von. As aves do Brasil. São Paulo: Typographia do Diario Official, 1907 (Catalogos da Fauna Brazileira, 1), p. XXI.

${ }^{203}$ Conforme já informado, durante a gestão Ihering, os espécimes de aves adquiridos de revendedores europeus provinham, em sua grande maioria, não do Brasil, mas de outros países da América do Sul, particularmente Venezuela, Colômbia e Equador. Ver MUSEU Paulista: Catálogo Accessional: Aves. Tomos 1 e 2. Acervo da Seção de Ornitologia do Museu de Zoologia da USP.
} 
devidas a fatores como sexo e idade), mas de diversas zonas do estado, do país e se possível do continente.

Tais coleções incluindo espécimes de diferentes regiões serviam não apenas para a detecção de variabilidades morfológicas regionais numa mesma espécie, mas também para a realização de estudos zoogeográficos. Para tanto, seriam requeridos trabalhos sistemáticos de exploração do território para obtenção de materiais. Os espécimes obtidos serviam para comprovar ou descartar o que dizia a literatura (se uma espécie de fato ocorria em determinada circunscrição territorial), bem como para ampliar o volume de espécies conhecidas ocorrentes em um território. Conforme o próprio Ihering:

\begin{abstract}
Nestas condições continuarei nos próximos anos na exploração das regiões do Estado, cuja natureza tem sido estudada só de um modo insuficiente, a fim de chegar ao ponto de conhecer exatamente a avifauna das diversas zonas do Estado e assim poder excluir, da lista das aves do Estado, todas as espécies indicadas como provenientes de S. Paulo, cuja verdadeira ocorrência aí não for comprovada por exemplares autênticos, guardados em nosso Museu ou em outras coleções científicas. ${ }^{204}$
\end{abstract}

Mas, para que tais espécimes se prestassem à função comprobatória ou de objeto de análise, seria necessário ter certeza de sua proveniência. Nesse sentido é que, segundo Ihering, a coleção ornitológica herdada do Museu Sertório era bastante problemática, uma vez que nem todos os exemplares indicados como provenientes de São Paulo eram de fato desse estado. Conforme o diretor, alguns daqueles exemplares supostamente paulistas eram na verdade provenientes de outras regiões do Brasil, como Bahia e Rio de Janeiro. ${ }^{205}$ Sendo assim, optou por não tomar os exemplares da Coleção Sertório como evidência suficiente para atestar a ocorrência de determinadas espécies no estado de São Paulo:

Não houve outro recurso senão deixar completamente de lado a coleção antiga e começar a nova, deixando fora de consideração todos os

\footnotetext{
204 IHERING, Hermann von. As aves do Paraguay em comparação com as de S. Paulo. Revista do Museu Paulista, 6, 1904, p. 345-346.

205 IHERING, Hermann von. As aves do Estado de S. Paulo. Revista do Museu Paulista, 3, 1898, p. 114. IHERING, Hermann von; IHERING, Rodolpho von. As aves do Brasil. São Paulo: Typographia do Diario Official, 1907 (Catalogos da Fauna Brazileira, 1), p. XII.
} 
espécimes do 'Estado de S. Paulo' dos quais não é confirmada pela nova coleção ou pela literatura, a ocorrência neste Estado. ${ }^{206}$

No caso da Mastozoologia, outro aspecto fundamental era a posse de crâneos, uma vez que Ihering advogava que a anatomia comparada dessas peças era essencial na determinação das espécies de mamíferos. Ele chama atenção sobre como, no caso das raposas, era particularmente necessário recorrer aos crâneos, já que as diferentes espécies eram fisionomicamente muito semelhantes, não podendo ser bem distinguidas a não ser pelo estudo comparado dos crâneos. ${ }^{207}$

Como vemos, para que as coleções zoológicas do Museu Paulista pudessem ser utilizadas para produção de conhecimentos (seja para a realização de inventários faunísticos, de revisões taxonômicas, ou de estudos zoogeográficos), elas deviam cumprir alguns requisitos. E, para que elas cumprissem tais requisitos, seria necessário empregar algumas estratégias de aquisição. Para formar séries amplas, que contemplassem diversidade regional, e cujos espécimes tivessem suas localizações corretamente identificadas, era preciso mandar o naturalista viajante do Museu em diversas expedições pelo interior, principalmente para as regiões mais longínquas e pouco exploradas. Mas, além disso, era preciso lançar mão de uma rede de coletores e intermediários aptos a colaborar com o museu, os quais remetiam (muitas vezes em troca de dinheiro) espécimes corretamente identificados e bem preparados, provenientes de diversos pontos do estado, do país e até da América do Sul.

\footnotetext{
${ }^{206}$ IHERING, Hermann von. As aves do Estado de S. Paulo. Revista do Museu Paulista, 3, 1898, p. 115.

${ }^{207}$ IHERING, Hermann von. Os mammiferos do Brazil Meridional: I Contribuição: Carnivora. Revista do Museu Paulista, 8, 1911, p. 199.
} 


\section{Exposições}

Como vimos, os espécimes exerciam, no âmbito do Museu Paulista, um papel de suma importância na elaboração dos estudos científicos sobre a natureza do país. Daí o esforço para a inserção da instituição em uma rede internacional de comércio que possibilitasse a ela adquirir esses objetos. Mas não eram apenas os estudos científicos que dependiam de espécimes adequados. As exposições também o requeriam, mas num sentido um pouco diferente.

No caso dos espécimes expostos ao público, o que estava em jogo era a elaboração de um discurso visual, por meio da mobilização de elementos materiais, capaz de veicular imagens de uma natureza construída pela ciência.

Para que se possa compreender o papel dos espécimes científicos na elaboração desse discurso que se oferece para ser visualmente apreendido, será necessário, num primeiro momento, caracterizar as exposições do Museu. Somente após examinar o que estava exposto, e como estava exposto, é que será possível desenvolver algumas análises sobre os objetos e sua forma de disposição no espaço expositivo.

Neste capítulo, examinaremos, portanto, com algum nível de detalhe, as exposições montadas no Museu Paulista durante a gestão Ihering, com particular atenção para as coleções zoológicas e, dentro destas, para as de aves e mamíferos - classes que ocupavam uma área expositiva consideravelmente maior que as demais.

Num primeiro momento, traçaremos um perfil das exposições: após tratar da reorganização a que é submetida a Coleção Sertório depois de doada ao estado, abordaremos a distribuição das coleções de diferentes disciplinas - e, no âmbito da Zoologia, de diferentes classes de animais - ao longo do espaço expositivo do edifício.

Depois disso, serão examinados os novos discursos e soluções expositivas que o Museu procurou incorporar ao longo do período estudado. Examinaremos como o Museu Paulista, em conexão com as inovações pelas quais vinham 
passando instituições congêneres, procurou incorporar espécimes preparados segundo técnicas taxidérmicas mais modernas e montar exposições que fugissem um pouco da ordenação puramente taxonômica, de acordo com as novas tendências de então.

Por fim, por meio de alguns relatos de cronistas e viajantes que visitaram o Museu, tentaremos esboçar algumas reflexões sobre o modo como o público apreendia as exposições durante o período Ihering.

\subsection{Caracterização}

Depois de doada ao Estado, a coleção do Coronel Joaquim Sertório - a qual constituiu o núcleo inicial a partir do qual se desenvolveram as coleções do Museu Paulista - sofreu dois processos substanciais de reorganização. Primeiro, foi dividida em duas partes: coleções de estudo e coleções de exposição. Segundo, foi separada por disciplinas.

Processos de reorganização como esses ocorreram em vários outros museus. Alberti fala num movimento, no século XIX, de "depuração" das coleções do (que viria a ser o) Museu de Manchester: uma tentativa de torná-las mais "científicas", descartando as "curiosidades". ${ }^{208}$ A reorganização das coleções provenientes do Museu Sertório pode ser entendida, portanto, como parte de um contexto em que as coleções de História Natural formadas há muito tempo eram enquadradas em padrões de cientificidade que vinham se tornando hegemônicos no que se refere à organização de coleções.

Trataremos aqui de cada um desses dois processos de reorganização implementados no início do Museu Paulista. Depois disso, caracterizaremos as exposições do Museu: primeiro seu arranjo geral; em seguida algumas salas específicas, as quais consideramos mais significativas.

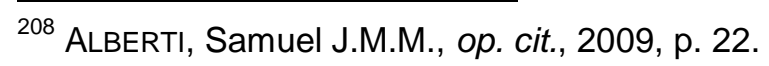


O princípio da divisão entre coleções de estudo - franqueadas somente a pesquisadores - e coleções destinadas ao público era a parte mais evidente da chamada New Museum Idea, um conjunto de mudanças que marcou a paisagem dos museus de História Natural na virada do século XIX para o XX. ${ }^{209}$

Mais do que isso, essa nova organização espacial das coleções, também conhecida como arranjo dual, consistiu numa mudança fundamental nos museus de História Natural, dando origem a um modelo institucional que predominou durante 0 século XX. ${ }^{210}$ George Brown Goode, do National Museum of Natural History, Estado Unidos, e William Henry Flower, do British Museum (Natural History), foram dois grandes difusores desse princípio de divisão das coleções. ${ }^{211} \mathrm{Na}$ Alemanha, Karl Möbius foi responsável por implantar o arranjo dual no Museum für Naturkunde de Berlim, durante sua gestão iniciada em $1887 .^{212}$

Hermann von Ihering refere-se, em diversos de seus escritos, a esse princípio de separação entre as coleções de estudo e aquelas expostas ao público. Por exemplo, no texto redigido a partir de sua viagem à Europa, onde pôde observar os museus do velho continente, o diretor do Museu Paulista tece uma série de considerações sobre o assunto. Segundo ele:

\begin{abstract}
Antigamente estavam expostos ao público todos os materiais que entravam nas coleções dos Museus. Daí provém esta infinidade de aves, mamíferos etc. empalhados, que enchem as vitrinas de numerosas salas e que, na sua uniformidade, cansam o público. Deve ser absolutamente condenado este procedimento imprudente. ${ }^{213}$
\end{abstract}

\footnotetext{
${ }^{209}$ Tais mudanças incluíam, além da divisão das coleções, a construção de novos edifícios, alteração nos métodos de administração e patrocínio dos museus, mudança nas relações sociais dentro dos museus, além de modificações científicas propriamente ditas no campo da História Natural e, sobretudo, abrir as portas para um público em massa. NYHART, Lynn K, op. cit., 2009, pp. 199-200.

${ }_{210}^{210}$ NYHART, Lynn K, op. cit., 2009, pp. 199-200.

${ }^{211}$ Sobre as ideias de William Henry Flower e George Brown Goode acerca do princípio da separação das coleções, ver ALVES, Ana Maria Alencar. Redutos da ciência na "era dos museus": Inglaterra, França, Estados Unidos e Brasil. São Paulo, 2004. Tese (Doutorado) - Faculdade de Filosofia, Letras e Ciências Humanas, Universidade de São Paulo, pp. 35-38 e 96-101. Sobre a adoção, por parte de lhering, dos princípios museológicos de Brown Goode - com quem, inclusive, manteve correspondência -, ver LOPES, Maria Margaret, op. cit., 1997, pp. 285-286 e ALVES, Ana Maria de Alencar, op. cit., 2001, pp. 82-88.

${ }^{212}$ NYHART, Lynn K, op. cit., 2009, pp. 198-245. Sobre Möbius, ver Ibidem, pp. 125-160. Lopes aponta que Möbius já havia adotado o princípio de separação das coleções quando era curador no Museu de Zoologia de Kiel, em 1884. LOPES, Maria Margaret, op. cit., 1997, p. 271.

${ }^{213}$ IHERING, Hermann von. A organização actual e futura dos museus de historia natural. Revista do Museu Paulista, 7, 1907, p. 434.
} 
De acordo com lhering, expor todo o material seria ruim: para os pesquisadores, que ficariam privados do estudo minucioso do material exposto; para as coleções, que, expostas em vitrines, deteriorar-se-iam mais facilmente; e para o próprio público, que se cansaria de ver tantas duplicatas. Ainda segundo o diretor, nem todos os museus já procediam segundo tal princípio, embora boa parte dos novos já o fizesse. ${ }^{214}$

A bipartição das coleções respondia, portanto, não apenas aos interesses científicos (melhor preservar as coleções e tornar factível o trabalho dos cientistas), mas também ao objetivo de se ter exposições mais interessantes e instrutivas para o público leigo. Segundo Ihering:

(...) hoje a intenção dos diretores destas coleções é tornar cada vez mais interessantes e instrutivas as coleções expostas ao público, o que exige uma escolha criteriosa dos objetos expostos. Pretende-se hoje expor menos exemplares ou objetos e tornar aqueles que foram escolhidos, mais instrutivos e atrativos ao público. ${ }^{215}$

O diretor tratou desse princípio organizativo também nos relatórios de gestão publicados na Revista do Museu Paulista. Já no primeiro deles, Ihering afirma que mesmo os grandes museus, como o de Londres e o de Berlim, deram início à separação de suas peças entre coleções de estudo e de exposição. Acrescenta que esse sistema traria vantagens tanto para as coleções de estudo, que ocupariam menos espaço, quanto para as coleções expostas, que seriam "escolhidas com todo critério". Afirma ainda que: "as experiências feitas neste sentido nos grandes Museus da Europa e dos Estados Unidos demostram a inconveniência de cansar o público com a exposição de objetos em demasia." 216

Ele voltou a defender tal princípio no relatório referente aos anos de 1899 e 1900, afirmando que, com essa divisão, as exposições seriam constituídas apenas pelas "peças mais importantes e melhor preparadas". Desse modo, as coleções expostas - as quais, segundo o diretor, "pretendem apenas ilustrar a natureza do

\footnotetext{
${ }^{214}$ IHERING, Hermann von. A organização actual e futura dos museus de historia natural. Revista do Museu Paulista, 7, 1907, p. 434.

215 Ibidem, p. 435.

${ }^{216}$ IHERING, Hermann von. Historia do Monumento do Ypiranga e do Museu Paulista. Revista do Museu Paulista, 1, 1895, pp. 20-21.
} 
país e a sua história", - serviriam de forma mais satisfatória à sua finalidade instrutiva. ${ }^{217}$

Essa insistência no tema se devia, segundo o próprio lhering, ao fato de esse sistema não ser bem compreendido entre os visitantes do Museu. Vários deles, não cientes da bipartição das coleções, afirmavam que elas eram "muito modestas". ${ }^{218}$ Pode-se também imaginar que essa recorrência do tema servisse para Ihering marcar a posição do Museu Paulista enquanto instituição museal afinada com os mais recentes padrões internacionais - deixando subentendido que no Museu Nacional ainda não ocorria a divisão das coleções. ${ }^{219}$

Quanto à questão da divisão disciplinar, consta que a coleção do Coronel Joaquim Sertório não estava espacialmente organizada desse modo. Ezequiel Freire, escrevendo sobre ela, apontava o quão deficiente era sua organização em relação aos padrões ainda vigentes no final do séc. XIX:

Não era o Coronel Sertório naturalista, e, sim, apenas colecionador. As suas coleções estavam dispostas mais em atenção ao efeito que pudessem produzir os grupamentos do que em vista das classificações científicas. Assim, na mesma vidraça, podiam casualmente encontrar-se reunidos indivíduos dos mais disparatados feitio e índole: - uma tartaruga ao lado de um beija-flor, um cristal de quartzo junto a uma espada histórica. ${ }^{220}$

Alexandre Hummel, preparador contratado para auxiliar no trabalho com o museu recém-doado ao estado, tece comentários semelhantes sobre sua organização: "Encontramos os mamíferos em parte promiscuamente com pássaros, peixes, etc. numa mesma vitrina (...)". Referindo-se aos insetos, diz o seguinte: "Há aí mais de 20 quadros e caixas, que ostentam o esplendor da classe, mas na

\footnotetext{
${ }^{217}$ IHERING, Hermann von. O Museu Paulista em 1899 e 1900. Revista do Museu Paulista, 5, 1902, p. 8. ${ }^{218}$ Ibidem, p. 8.

${ }^{219}$ No Museu Nacional, a divisão entre coleções de estudo e de exposição ocorreu de modo pleno apenas a partir das décadas de 1940-50. Ver ARANHA FILHO, Jayme Moraes. Guia da impermanência as exposições: uma investigação sobre transformações do Museu Nacional do Rio nos anos 1940. Rio de Janeiro, 2011. Tese (Doutorado) - Instituto de Filosofia e Ciências Sociais, Universidade Federal do Rio de Janeiro. Sobre as polêmicas entre o Museu Paulista e o Museu Nacional, ver LOPES, Maria Margaret, op. cit., 1997, pp. 292-295.

${ }^{220}$ FrEIRE, Ezequiel, citado por TAUNAY, Afonso de E. Comemoração do cinquentenário da solene instalação do Museu Paulista. Separata de Administração Pública, 3, 4, dez. 1945. São Paulo: Governo do Estado de São Paulo, Departamento do Serviço Público, Serviço de Documentação, 1946, p. 19. Ezequiel Freire publicou um artigo na imprensa paulista, nos anos de 1880, sobre a Coleção Sertório. Parte do artigo foi reproduzida na obra citada de Taunay.
} 
verdade dispostos com este único fim de agradar a vista sem atender ao arranjo sistemático."221

Ao assumir a direção do Museu Paulista, Ihering passou a reorganizar esse material. Segundo ele: "(...) quem conheceu estas coleções antigamente, desde logo convencer-se-á, de que já se aumentaram e completaram, assim como da mudança na preparação, colocação e determinação."222 O diretor do Museu afirmou ainda - em carta dirigida a Cesário Mota Júnior por ocasião da saída desse do cargo de Secretário do Interior - que a "câmara de curiosidades" do Coronel Joaquim Sertório, reorganizada após ser doada ao estado, teria se transformado num verdadeiro "instituto científico". 223

É verdade que esse trabalho já havia sido iniciado por Löfgren. Quando ele assume interinamente, em 1891, a direção do museu recém-doado ao estado, elabora um plano de classificação, pelo qual os objetos são divididos em cinco seções: Zoologia; Botânica; Geologia e Mineralogia; Antropologia e Etnografia; História e Artefatos. Cada seção, por sua vez, é subdividida em séries. ${ }^{224}$

Hummel, por sua vez, faz referência ao trabalho de identificação, numeração, nova etiquetagem e registro em livro apropriado efetuado por ele e Friedenreich preparadores contratados juntamente com Löfgren para organizar o museu que passava para a administração pública. As coleções, embora não tenham sido reorganizadas espacialmente - já que, segundo Hummel, isso só deveria ser feito quando o museu passasse a ser abrigado em local mais espaçoso e apropriado foram etiquetadas com números, de modo que os objetos posteriormente pudessem ser distribuídos espacialmente segundo o plano de classificação esboçado por Löfgren. ${ }^{225}$

221 HUMmel, Alexandre. Primeiro Relatório sobre as atuais condições do Museu do Estado, apresentado ao diretor do mesmo por Alexandre Hummel, ajudante interino. São Paulo, Outubro de 1891, p. 6 e pp. 18-19. Museu Paulista, Coleção Harold Alexandre Hummel.

${ }_{222}$ IHERING, Hermann von. Historia do Monumento do Ypiranga e do Museu Paulista. Revista do Museu Paulista, 1, 1895, p. 20 (grifo nosso).

${ }^{223}$ CARTA de Hermann von Ihering a Cesário Mota Júnior. São Paulo, 07/08/1895. APMP/FMP. Série Correspondência.

${ }^{224}$ MUSEU. O Estado de S. Paulo, 10/05/1891, p. 2.

225 HUMmel, Alexandre. Primeiro Relatório sobre as atuais condições do Museu do Estado, apresentado ao diretor do mesmo por Alexandre Hummel, ajudante interino. São Paulo, Outubro de 1891, pp. 3-6. Museu Paulista, Coleção Harold Alexandre Hummel. Sobre a doação da Coleção Sertório ao estado e esse período pré-lhering do Museu Paulista, ver LOPES, Maria Margaret, op. cit., 1997, pp. 266-267; e CARVALHO, Paula Carolina de Andrade, op. cit., 2013, pp. 120-126. O museu do 
A divisão disciplinar e a opção pelo arranjo dual constituíram opções expositivas de base, as quais condicionaram o modo como foi organizado o discurso expográfico do Museu Paulista. Exposições compartimentadas em campos disciplinares eram capazes de, ao justapor séries de objetos semelhantes, explorar as relações de "parentesco" entre essas peças. No caso da Etnografia e da Arqueologia, tratava-se de explorar as relações de influência entre diferentes culturas, relações percebidas pelas semelhanças entre os artefatos provenientes de diferentes grupos. Já no caso da Zoologia, ao agrupar conjuntos de animais de uma mesma categoria, tratava-se de evidenciar a organização lógica que existiria na própria natureza. ${ }^{226}$

A divisão entre coleções de estudo e de exposição, por sua vez, condicionou o arranjo expositivo de forma ainda mais impactante. Uma vez que a maior parte das coleções foi removida dos olhos do público, e que o material exposto pôde prescindir dos requisitos das peças destinadas aos estudos científicos, o curador passou a dispor de espaço e liberdade para elaborar exposições mais criativas, destinadas especificamente ao público não especializado.

\subsubsection{O arranjo expositivo}

Para caracterizar as exposições, utilizamo-nos principalmente do Guia pelas collecções do Museu Paulista, publicado em 1907, o qual apresenta um retrato detalhado de como eram elas durante a gestão Ihering. ${ }^{227} \mathrm{O}$ arranjo das salas de

coronel Joaquim Sertório funcionava num prédio no Largo Municipal (mais tarde praça João Mendes); em 1892 a coleção foi transferida para uma casa no Largo do Palácio (hoje Pátio do Colégio), em 1893 para a sede da Comissão Geográfica e Geológica e, em 1894, para o Monumento do Ipiranga. Ver LOPES, Maria Margaret, op. cit., 1997, p. 267 e p. 271.

${ }^{226}$ Bennett contrapõe os modos de ver imbricados nos sucessivos modelos museais. Enquanto os gabinetes de curiosidades renascentistas implicavam um olhar errante, capaz de capturar objetos organizados dialogicamente, no museu renascentista temos um olhar disciplinado, uma vez que acesso aos objetos é totalmente mediado pela autoridade da palavra. Já no museu evolutivo, objeto de estudo do autor, o olhar também é direcionado pelas palavras, mas agora não mais para os objetos, mas para os espaços entre eles, já que nesse paradigma museal o que importa são as relações de descendência que ligam um objeto a outro. Ver BENNETT, Tony. Pasts Beyond Memory: Evolution, Museums, Colonialism. London: Routledge, 2004, pp. 160-186.

${ }^{227}$ A tiragem de 3.000 exemplares, que era vendida aos visitantes interessados, esgotou-se em 1911. Ver LOPES, Maria Margaret, op. cit., 1997, p. 277. Aranha, referindo-se aos guias de coleções publicados pelo Museu Nacional entre 1915 e 1924, enfatiza que não se tratava de guias de 
exposição descrito no Guia é praticamente o mesmo elaborado quando da inauguração da instituição em 1895, a não ser pela sala de Etnografia dedicada aos índios Carajás (B 16), que no primeiro arranjo também abrigava mamíferos conforme descrito no volume 1 da Revista do Museu Paulista. ${ }^{228}$

As exposições públicas ocupavam o primeiro andar do edifício-monumento do Ipiranga (figura 2). Conforme podemos ver na planta desse pavimento (figura 3), ao longo de 17 salas eram distribuídas as coleções de Zoologia, Mineralogia, Paleontologia, Arqueologia, Antropologia, Etnologia e História Pátria.

As salas da Ala Leste abrigavam coleções de Zoologia: insetos; peixes do mar; répteis, anfíbios, peixes de água doce; cobras; e aves (três salas, sendo duas grandes e uma pequena). O corpo central era dedicado à História Pátria: duas salas de objetos históricos e uma sala grande (Salão de Honra) contendo a pintura Independência ou Morte, de Pedro Américo. Já a Ala Oeste era dedicada a diferentes disciplinas: Zoologia - duas salas grandes dedicadas aos mamíferos e uma sala com corais, conchas, caranguejos, aranhas, etc.; Mineralogia e Paleontologia - uma sala; Antropologia e Etnografia - uma sala dedicada aos índios do Brasil e outra aos índios Carajás; Numismática - uma sala. Fotografias das salas onde estavam expostas as coleções zoológicas podem ser vistas nas figuras 4 a 13 .

Diferente do que ocorria em alguns museus europeus, não existia, ao que tudo indica, um percurso hierárquico na distribuição dessas coleções pertinentes a

exposições. Eram na verdade obras de introdução a disciplinas científicas às quais o museu se dedicava - foram publicados três guias, referentes às coleções de Antropologia, Arqueologia Clássica, e Mineralogia, Geologia e Paleontologia. Nesses guias, apenas eventualmente eram citadas peças do museu, como exemplos dos tópicos tratados. Ver ARANHA FILHO, Jayme Moraes, op. cit., 2011, pp. 106-112. Já o Guia pelas collecções do Museu Paulista aglutinava as duas funções. A primeira parte apresenta um resumo de Sistemática zoológica, visando introduzir o leitor no sistema de classificação adotado pelo Museu para organizar seus exemplares da fauna nacional. Nesse sentido, numa função semelhante a dos guias do Museu Nacional, visava munir o leitor das ferramentas intelectuais necessárias para a apreciação das coleções expostas. Além disso, tratavase também de um guia de exposição propriamente dito: a segunda parte contém uma relação do que havia nas exposições sala por sala. O Guia objetivava, portanto, não só instruir o leitor sobre os preceitos básicos de Taxonomia zoológica, a fim de que ele pudesse compreender o que veria (ou havia visto) no Museu. Pretendia também apresentar cada vitrine exposta, dando destaque e atribuindo novas camadas de significado a algumas das peças ali contidas.

${ }^{228}$ ver IHERING, Hermann von. Historia do Monumento do Ypiranga e do Museu Paulista. Revista do Museu Paulista, 1, 1895, pp. 28-29. Segundo Rodolpho von Ihering, em artigo pulicado n'O Estado de S. Paulo, com a ampliação da coleção de artefatos Carajás, foi preciso transferi-la da sala de Etnografia para a sala B 16, “(...) onde em três armários figura só este conjunto de artefatos aliás belíssimos dos índios do Araguaia (...)". IHERING, Rodolpho von. Museu Paulista - a Seção Etnográfica. O Estado de S. Paulo, 15/07/1910, p. 5. 
diferentes disciplinas ao longo das salas de exposição. No Museu de Altona, Alemanha, por exemplo, o primeiro pavimento era dedicado à Geologia e à Oceanografia, o segundo à Zoologia e à Botânica e o terceiro à cultura material humana. Segundo Nyhart, tal visão de mundo estratificada - que considera a existência de um substrato físico que condiciona a natureza biótica, a qual por sua vez determina as características da cultura - aparecia também em outros museus não especializados (multidisciplinares) do final do século XIX e princípio do XX. ${ }^{229}$

Tampouco, no caso das coleções zoológicas expostas no Museu Paulista, existia um percurso evolutivo. Isto é, a visita não começava pelos animais considerados menos complexos para terminar nos mamíferos. A disposição das coleções do Museu segundo esse tipo de lógica deve ter sido limitada pela planta do prédio que o abrigava. Segundo o Guia escrito por Rodolpho von Ihering, no que se refere à disposição das coleções zoológicas, foi preciso "acomodar as diversas classes de animais segundo o espaço de que podia dispor", uma vez que o Monumento do Ipiranga não havia sido construído com o objetivo prévio de abrigar um museu. ${ }^{230}$

Ou seja, era preciso organizar, segundo a configuração espacial existente, coleções de diferentes tamanhos. Algumas coleções eram mais volumosas do que outras - como as de aves e mamíferos, que ocupavam as maiores salas (excetuando o Salão de Honra) e também a maior superfície em termos de área. Isso poderia ocorrer seja devido ao maior número de espécimes dessas coleções (o que poderia ou não se dever ao maior número de espécies ocorrentes em determinado grupo taxonômico), seja por conta de ocuparem mais espaço devido ao tamanho dos seus espécimes, seja pelo fato de o Museu pretender Ihes dedicar mais espaço, pois as considerava de maior interesse para os visitantes. Para tais coleções, era preciso usar as salas maiores situadas nas extremidades das alas,

\footnotetext{
${ }^{229}$ NYHART, Lynn K, op. cit., 2009, p. 275. O Museu de La Plata também apresentava tal organização hierárquica das disciplinas ao longo do espaço expositivo. Ver LOPES, Maria Margaret, op. cit., 1997, p. 232, nota 10.

${ }^{230}$ IHERING, Rodolpho von. Guia pelas collecções do Museu Paulista. São Paulo: Cardozo, Filho \& Cia, 1907, p. 6. Esse problema, certamente, não era exclusivo do Museu Paulista. No British Museum (Natural History), seu diretor, Henry Flower, apontou que a configuração espacial do prédio impediu o arranjo das exposições numa perspectiva evolutiva. Ver BENNETT, Tony, op. cit., 2004, p. 73. Alberti, tratando do Museu de Manchester, refere-se às restrições impostas à formulação das exposições pelo espaço e pelas características dos objetos expostos (tamanho, etc.). $\mathrm{O}$ autor indica que essas limitações por vezes impediam que o arranjo expositivo obedecesse a critérios eminentemente científicos. AlBERTI, Samuel J.M.M., op. cit., 2009, pp. 33-34.
} 
mesmo que isso impedisse a configuração de um percurso evolutivo que começasse pelos animais considerados mais simples e terminasse nos considerados mais complexos.

As limitações espaciais também impossibilitavam a existência de salas especificamente dedicadas à galeria artística. Por isso, estando o espaço dedicado às exposições públicas já totalmente ocupado, os quadros que iam sendo adquiridos pelo Museu eram abrigados nas salas onde se achavam expostas coleções de História Natural, o que, segundo Ihering, além de "ser inconveniente e pouco decente, tem provocado da parte dos visitantes comentários desagradáveis." 231

A despeito das limitações impostas pelo prédio, procurou-se, de algum modo, dar um agrupamento lógico à distribuição das coleções pelo edifício: o corpo central era dedicado à História Pátria (o Salão de Honra com a tela de Pedro Américo, além das duas salas com objetos históricos); uma das alas era dedicada exclusivamente à Zoologia; a outra, além da Zoologia, abrigava coleções das demais disciplinas. Todavia, as coleções de Mineralogia e Paleontologia, Antropologia e Etnografia e Numismática parecem ter ficado "perdidas" em meio a três salas dedicadas à Zoologia (duas a mamíferos e uma a corais, conchas, caranguejos, aranhas, etc.).

Embora o acesso ao primeiro andar fosse feito a partir da escadaria existente no corpo central, o percurso sugerido começava a partir da extremidade da Ala Leste. Ao menos é desse ponto que o Guia inicia sua descrição das salas de exposição - sendo que a publicação informa que, para facilitar a consulta pelo visitante, disporia o texto “(...) exatamente à ordem em que os preparados zoológicos se acham dispostos na seção franqueada ao público."232

\footnotetext{
${ }^{231}$ IHERING, Hermann von. O Museu Paulista em 1901 e 1902. Revista do Museu Paulista, 6, 1904, p. 6. Sobre as considerações de Ihering quanto à necessidade de construir um edifício específico para abrigar a galeria artística do Museu, bem como sobre a transferência de parte das pinturas do acervo do Museu Paulista para a recém-criada Pinacoteca do Estado em 1905, ver BARBUY, Heloisa, op. cit., 2005, p. 38; e BARBUY, Heloisa. "O Museu Paulista e a Pinacoteca do Estado". In: ARAUJo, Marcelo Mattos \& Camargos, Marcia (orgs.). Pinacoteca: a história da Pinacoteca do Estado de São Paulo. São Paulo: Artemeios, 2007, pp. 137-145.

${ }^{232}$ IHERING, Rodolpho von, Guia cit., 1907, p. 6. Apesar desse percurso sugerido, é provável que o público visitasse as alas indo do centro para as extremidades, já que o acesso ao primeiro andar era feito pela escadaria do corpo central, como até os dias de hoje, de acordo com a circulação prevista no projeto arquitetônico de Tommaso Gaudenzio Bezzi. Alfredo Moreira Pinto, professor e jornalista carioca que publicou relato de sua visita a São Paulo feita no ano de 1900, faz sua descrição das salas de exposição do Museu segundo um percurso que tem início no corpo central, daí segue percorrendo as salas da Ala Leste (do centro para a extremidade), depois retorna para o corpo central
} 
O Guia inicia sua descrição das salas, portanto, com a coleção de aves; passa por salas dedicadas a répteis, anfíbios, peixes e insetos; depois chega ao corpo central, com suas salas abrigando objetos históricos. Por fim, parte para a Ala Oeste, com suas salas dedicadas à Zoologia e às demais disciplinas (Mineralogia e Paleontologia, Antropologia e Etnografia e Numismática).

No que se refere às salas de exposição dedicadas à Zoologia - que ocupavam a maior parte da superfície do prédio dedicada à apreciação pública existia, antes de tudo, um recorte geográfico. Isto é, eram expostos os animais pertencentes à região neotropical, a não ser por algumas exceções (as salas dedicadas a aves e mamíferos, por exemplo, continham, cada uma, uma vitrine dedicada a animais estrangeiros). Aliás, como era de se esperar, já que, segundo o próprio regulamento do Museu, esse deveria se encarregar de coligir, estudar e expor objetos da História Natural sul-americana, em particular do Brasil e do estado de São Paulo. ${ }^{233}$

Embora haja tal recorte de caráter geográfico, o princípio geral de organização das coleções expostas era sistemático. Havia uma unidade espacial para cada classe (ou outro nível taxonômico): uma dedicada a aves, outra a mamíferos, outra a insetos, etc. Tal unidade espacial poderia ser uma sala, um conjunto de salas (como no caso das aves e mamíferos), ou mesmo parte de uma sala (no caso de salas divididas por mais de uma classe, como naquela destinada a répteis, anfíbios, peixes). A organização geral não era, portanto, segundo critérios zoogeográficos (por exemplo, uma sala para animais da Amazônia, outra para animais do estado de São Paulo, etc.); ou então temáticos (uma exposição dedicada à evolução, outra a animais danosos à agricultura, etc.). Todavia, como veremos, no interior de cada sala não eram somente critérios provenientes da Sistemática que orientavam a distribuição das exposições: subcritérios zoogeográficos e temáticos permeavam a organização geral de caráter sistemático. Havia, portanto, soluções mistas nos arranjos expositivos, que mesclavam diferentes critérios científicos e se adaptavam aos espaços físicos disponíveis.

e segue percorrendo as salas da Ala Oeste. Ver PINTO, Alfredo Moreira. A cidade de São Paulo em 1900: impressões de viagem. 2a. ed. São Paulo: Governo do Estado de São Paulo, 1979 (1‥ ed. 1900), pp. 84-85.

${ }^{233}$ Ver nota 42. 


\subsubsection{Dentro das salas}

Embora houvesse, no que se refere à distribuição geral dos objetos ao longo da superfície do edifício dedicada às exposições públicas, uma divisão disciplinar e, no caso das coleções zoológicas, uma organização sistemática, existiam, muitas vezes, no interior de cada sala, outros critérios de organização. Vejamos com atenção os casos das coleções de mamíferos e aves.

Nas salas que abrigavam os mamíferos (figuras 12 e 13), existia apenas uma vitrine dedicada a "mamíferos estrangeiros", exibindo "alguns dos principais tipos da fauna extra-americana". ${ }^{234}$ De resto, procurava-se apresenta-los (os mamíferos neotropicais) segundo uma divisão sistemática. Cada vitrine agrupava exemplares de uma ou mais ordens - segundo o sistema de classificação então adotado pelo Museu, exposto na parte primeira do Guia.

Sendo assim, havia, por exemplo: uma vitrine dedicada a roedores, abrigando uma capivara e roedores de menor porte; uma dedicada a ungulados, contendo uma anta, porcos do mato e algumas anomalias ou "monstruosidades" 235 (igualmente ungulados); uma com pequenos carnívoros; uma com grandes carnívoros; duas dedicadas a primatas; uma com morcegos; uma com marsupiais; e uma dedicada a desdentados, contendo tamanduás, tatus e preguiças.

No caso das vitrines dedicadas aos primatas neotropicais (figura 13), existia ainda outro critério interno de organização, que não era sistemático, mas zoogeográfico. Os primatas estavam divididos em duas vitrines (ou armazenados em dois grupos em uma vitrine dupla): uma dedicada aos macacos do sul do Brasil, especialmente do estado de São Paulo; outra contendo macacos da Amazônia - ver a figura 13.

Destaque-se que a inauguração desta nova vitrine está diretamente relacionada à expedição de Garbe à Amazônia, realizada entre 1901 e 1902, onde

\footnotetext{
${ }^{234}$ IHERING, Rodolpho von, Guia cit., 1907, p. 107. O Guia utiliza o termo "armário" para se referir aos móveis de exposição e "vitrina" para cada uma das divisões internas desses móveis. Preferimos, todavia, utilizar neste trabalho os termos "vitrine" ou "vitrina" para nos referirmos aos móveis. Afinal, uma vez que se trata de peças envidraçadas destinadas especificamente à exposição de coleções, o termo "vitrine" (ou "vitrina") expressa melhor seu significado.

${ }_{235}$ Termo utilizado para designar animais com características anormais resultantes do desenvolvimento irregular do feto. Por exemplo, animais com duas cabeças.
} 
coletou diversos materiais para o Museu Paulista. Afinal, a vitrine dedicada aos macacos da região amazônica possuía 28 exemplares, em sua maioria coletados por Garbe durante a referida expedição. ${ }^{236}$ Em relatório referente aos anos de 1901 e 1902, Ihering já havia informado que, entre as "ricas e variadas coleções" enviadas por Garbe da região do rio Juruá, estavam "14 espécies de macacos daquela zona, o que representa o duplo das espécies que vivem no Estado de S. Paulo". 237

No caso da coleção de aves exposta ao público (figuras 4 e 5), assim como na de mamíferos, existia apenas uma vitrine dedicada a animais estrangeiros. As demais continham aves ocorrentes na região neotropical. Mais uma vez, ocorria uma divisão sistemática na distribuição dos objetos expostos ao público: as aves estavam agrupadas por ordens e, no caso dos pássaros, também por famílias. Além disso, havia uma sala dedicada a ninhos e ovos de aves (duas vitrines com ninhos e uma com ovos). Existia ainda uma vitrine com peças de Anatomia e Teratologia ornitológica: esqueletos e outros preparados anatômicos de aves, bem como de aves com anomalias.

A primeira sala de aves continha sete vitrines: três dedicadas a pássaros; uma com pica-paus, tucanos, papagaios, araras e periquitos; uma com pernaltas (jaburus, garças, socós e guarás); além de duas outras vitrines com aves de diversas famílias. A segunda sala era dedicada a ninhos e ovos de aves (duas vitrines com ninhos e uma com ovos). A terceira sala apresentava: uma vitrine dedicada a aves extra brasileiras; uma dedicada a peças de Anatomia e Teratologia ornitológica; uma com aves aquáticas; uma com aves de rapina; além de uma contendo ema, seriema, cigana e aves apreciadas como caça (como perdizes e codornas).

Vale ressaltar que, em meio a essa organização geral de caráter sistemático, existiam espaços para outros modos de exposição. Algumas aves eram agrupadas de modo a indicar as relações, ocorrentes na natureza, entre indivíduos da mesma ou de diferentes espécies. Esse é o caso do "grupo biológico da Coruja do Campo

\footnotetext{
${ }^{236}$ IHERING, Rodolpho von. O Museu Paulista nos annos de 1903 a 1905. Revista do Museu Paulista, 7,1907, p. 12.

${ }^{237}$ IHERING, Hermann von. O Museu Paulista em 1901 e 1902. Revista do Museu Paulista, 6, 1904, p. 17.
} 
onde se os vê reunidos em família em frente ao ninho", ${ }^{238}$ existente na vitrine dedicada às aves de rapina. Ou do "grupo biológico que mostra a espécie de Marreca (Nettion brasiliense) mais comum nos arredores de São Paulo". ${ }^{239}$

Já a exposição de ninhos e ovos de aves revela um interesse por aspectos da biologia das aves. Como vimos no capítulo anterior, o estudo da biologia das aves no Museu Paulista empregava muitas vezes os métodos da Sistemática. Ou seja, o Museu reunia ninhos e ovos de aves com a finalidade de, analisando-os e os comparando, formar conhecimentos sobre os processos de nidificação. Os visitantes do Museu - por meio de uma amostra desse tipo de material - poderiam eles mesmos, comparando cores e formas de ninhos e ovos de diferentes espécies, tentar apreender variações no comportamento das aves no que tange a postura de ovos e fatura de ninhos.

Além disso, devemos citar a vitrine dedicada a peças de Anatomia e Teratologia ornitológica, onde figuravam “(...) esqueletos e vários outros preparados anatômicos das aves, bem como monstruosidades, devidas ao desenvolvimento anormal das aves ou de seus ovos." ${ }^{240}$ Tais monstruosidades, ao mesmo tempo em que eram capazes de chamar atenção dos visitantes, apresentam um caráter científico, evidenciado pelo próprio nome a ela atribuído pelo Guia (Teratologia). Ou seja, tratava-se não só de chamar a atenção dos visitantes, mas de instruir sobre a questão do desenvolvimento anormal dos fetos.

Tanto aves quanto mamíferos estavam, portanto, submetidos a um arranjo geral taxonômico. Dividido em ordens e famílias, o conjunto dos espécimes apresentava uma visão de natureza como sistema submetido a uma ordem que podia ser aferida por caracteres morfológicos. Contudo, sob essa organização sistemática de base, existiam outras modalidades expositivas. Eis o caso da referida vitrine de primatas brasileiros: o critério zoogeográfico transmitia uma visão das variações regionais na distribuição de animais ao longo do território do país. No caso dos grupos biológicos de aves, ou das peças de Anatomia e Teratologia de aves e

\footnotetext{
${ }^{238}$ IHERING, Rodolpho von, Guia cit., 1907, p. 88.

239 Ibidem, p. 88.

${ }^{240}$ Ibidem, p. 89.
} 
mamíferos, vemos que esses objetos, embora encaixados no interior da organização taxonômica, não são apenas peças desse sistema. Eles possuem outras camadas de sentido. São representações do comportamento de determinadas espécies ou sobre outros tópicos da Biologia animal.

Aliás, esse assunto, Biologia animal, estava presente em várias das salas dedicadas a outras categorias de animais. Por exemplo, na sala destinada a répteis, anfíbios e peixes de água doce, havia um vidro com "(...) as fases por que sucessivamente passa a rã no seu desenvolvimento (ovo, girino, com 2 pés, com 4 pés, filhote e adulta)." 241 $\mathrm{Na}$ sala dedicada a cobras, por sua vez, existia: uma preparação de glândula de veneno de cobra; quatro tubos contendo amostras de venenos de cobras; além de frascos de soro antiofídico. ${ }^{242}$

Havia ainda, na sala de Entomologia, além de uma mostra de "Biologia dos Insetos" - contendo lagartas e casulos de borboletas -,vitrine abrigando casos de mimetismo (capacidade que possuem determinados organismos de se assemelharem a outros, adquirindo assim uma vantagem adaptativa, como proteção contra predadores):

Tais casos são: um gafanhoto que, com asas em repouso, imita a forma de uma folha verde; um percevejo cujo corpo parece com espinhos de uma roseira; Phasmidas (Orthopteros), imitando galhos secos; borboletas em repouso com o lado inferior da asa em forma e de cor de folhas ou imitando, com a asa aberta, a casca da árvore, etc. ${ }^{243}$

Esse perfil expositivo que amalgamava diferentes critérios de organização não era exclusivo do Museu Paulista. No caso da Alemanha, como mostra Köstering, exposições mais tradicionais, com os espécimes organizados taxonomicamente, muitas vezes conviviam, num mesmo museu, com outras que tinham a Biogeografia, a Biologia ou a Ecologia como princípio ordenador. Embora a Sistemática viesse perdendo espaço para essas outras perspectivas científicas enquanto princípio de organização das coleções expostas, ela permanecia como

\footnotetext{
241 Ibidem, p. 92.

242 Ibidem, p. 90.

243 Ibidem, p. 97.
} 
pano de fundo ou quadro conceitual geral das exposições na maior parte dos museus. $^{244}$

Nyhart, apontando na mesma direção, indica como esse modelo, que combinava um arranjo geral sistemático a exposições de tópicos biológicos, espalhou-se pela Alemanha na virada para o século XIX:

\begin{abstract}
As museums across Germany gradually reformed their exhibits over the 1890 s and early 1900s, they would follow suit. While most maintained a systematic overview, they would add biological displays to their public exhibits. Virtually all provincial museums had a local faunal collection with exhibits of harmful and useful animals (especially insects and birds), and exhibits of mimicry and adaptive coloration were extremely popular. ${ }^{245}$
\end{abstract}

Esse era o caso, por exemplo, das exposições do Museum für Naturkunde de Berlim. Nyhart trata das modificações ali introduzidas durante a gestão de Karl Möbius (iniciada em 1887) - gestão marcada pela mudança do Museu para um novo edifício, onde seria adotada a divisão entre coleções de estudo e de exposição. Möbius, bebendo em concepções expositivas provenientes de outros museus, combinadas com novidades desenvolvidas por ele e seus curadores, foi responsável por dar impulso a um novo modelo de museu de História Natural na Alemanha, modelo esse em que a preocupação com a educação do grande público seria algo importante. ${ }^{246}$

Möbius concebia as exposições como um livro tridimensional de Zoologia, destinado a ensinar aos visitantes sobre os mais diversos aspectos da História Natural. E esses diversos aspectos seriam apresentados sob diferentes soluções expositivas. ${ }^{247}$ Segundo Nyhart: "The opportunity to move beyond the limits of classificatory display combined with the new emphasis on explanation to unleash an extraordinary burst of exhibitionary creativity, resulting in an eclectic mix of topics and forms of display."248

\footnotetext{
${ }^{244}$ Ver KÖSTERING, Susanne, op. cit., 2003.

${ }^{245}$ NYHART, Lynn K, op. cit., 2009, p. 235.

${ }^{246}$ Ibidem, pp. 223-235.

247 Ibidem, pp. 229-231.

${ }^{248}$ Ibidem, p. 231.
} 
A seção de insetos do Museum für Naturkunde, por exemplo, continha, para além da organização geral de caráter sistemático, uma exibição dedicada ao fenômeno de "mimicry", outra à coloração sazonal das borboletas europeias, além de uma "fazenda" de formigas com insetos vivos, construída com paredes de vidro para deixar visíveis os túneis fabricados pelos animais. Desse modo, segundo Nyhart, nessa seção, exposições de grande apelo visual veiculavam conhecimentos biológicos de importantes consequências teóricas (mimetismo e fisiologia da coloração). ${ }^{249}$

\section{2. $O$ contexto internacional: os Ihering vão à Europa}

Como vemos, em meio ao arranjo geral de caráter sistemático, existia uma série de outras soluções expositivas no Museu Paulista, visando veicular aspectos de Zoogeografia e Biologia animal. Conforme vimos para o caso da Alemanha, soluções expositivas como essas vinham ganhando força nos museus de História Natural entre o final do séc. XIX e o início do XX - particularmente em instituições dos grandes centros da Europa e dos Estados Unidos. Vejamos então como Ihering tomou ciência dessas mudanças que vinham se desenvolvendo nos museus de estrangeiros e qual sua opinião sobre elas.

Por mais que pudesse estar a par do assunto por vias indiretas (correspondência e literatura especializada, supomos), Ihering advogava a necessidade de conferir tais inovações in loco, já que não seria "possível conhecer perfeitamente assuntos desta ordem só pela leitura de relatórios". Por isso, o diretor pleiteou, junto à Secretaria do Interior, uma viagem à Europa, sem perda de salário, para o zelador do Museu, seu filho Rodolpho von Ihering. ${ }^{250}$ Conforme o diretor,

\footnotetext{
249 Ibidem, p. 231.

${ }^{250}$ Conforme apontamos anteriormente, o cargo de zelador ou custos equivalia ao de um curador responsável por assistir o diretor na conservação, organização, catalogação e demais atividades de caráter técnico-científico envolvendo as coleções do Museu. Ver nota 52 retro.
} 
seria importante, para o progresso do Museu Paulista, que o zelador conhecesse "outros estabelecimentos modernos e modelos". ${ }^{251}$ Afinal:

O modo de expor os objetos e sua escolha e explicação tem feito grande progresso no último decênio, existindo a tendência de reservar grande número de objetos para as coleções de estudo, expondo-se ao público, menos objetos, mas estes melhor escolhidos e preparados e mais instrutivos pelas informações dos rótulos.

Muitas entre as modificações modernas dos grandes museus não são aplicáveis ao nosso por falta de recursos e de espaço, mas outras nos serão de grande proveito. ${ }^{252}$

Tal viagem realizou-se no ano seguinte, 1905, quando o zelador do Museu seguiu para a Europa a fim de "completar sua instrução científica" - realizando estudos na Universidade de Heidelberg - e "(...) estudar os estabelecimentos congêneres, conhecer o progresso que tem sido feito nos últimos decênios na exposição, preparação e conservação de objetos de museus semelhantes."253

Não temos registro, todavia, de quais museus Rodolpho von Ihering visitou, o que viu neles e como isso se traduziu ou não em modificações no Museu Paulista. No entanto, o próprio Hermann von Ihering realizou viagem ao velho continente, entre abril e novembro de 1907, e, diferentemente do filho, deixou-nos um relato acerca das transformações pelas quais vinham passando as exposições dos museus visitados. ${ }^{254}$ Nesse relatório de viagem, ele destaca algumas das inovações expositivas vistas:

${ }^{251}$ Ofícıo de Hermann von Ihering ao Secretário do Interior e da Justiça, São Paulo, 18/02/1904. APMP/FMP, Série Correspondência.

252 Ofíclo de Hermann von Ihering ao Secretário do Interior e da Justiça, São Paulo, 18/02/1904. APMP/FMP, Série Correspondência.

${ }^{253}$ Ofíclo [de Hermann von Ihering] ao Secretário do Interior e da Justiça, São Paulo, 02/03/1905. APMP/FMP, Série Correspondência; OfícIO [de Hermann von Ihering] ao Secretário do Interior, São Paulo, 09/10/1905. APMP/FMP, Série Correspondência; OFíclo [de Hermann von Ihering] ao Secretário do Interior, São Paulo, 11/10/1905. APMP/FMP, Série Correspondência. Segundo Lopes, Rodolpho von Ihering também realizou uma viagem à Europa em 1911, com a finalidade principal de realizar estudos zoológicos nos laboratórios da Universidade de Viena e do Museu de Paris. Ver LOPES, Maria Margaret, op. cit., 1997, p. 285.

${ }^{254}$ OfícIO [de Hermann von Ihering] ao Secretário do Interior, São Paulo, 09/04/1907. APMP/FMP, Série Correspondência; Ofíclo de Rodolpho von Ihering ao Inspetor do Tesouro, São Paulo, 23/10/1907. APMP/FMP, Série Correspondência; OFícIO de Hermann von Ihering ao Secretário do Interior, São Paulo, 18/11/1907. APMP/FMP, Série Correspondência. Lopes trata tanto da viagem de Ihering, quanto da do diretor do Museu Nacional, João Batista de Lacerda, que também foi à Europa, em 1911, e deixou relato com suas impressões das transformações pelas quais vinham passando os 
Instrutivos e belos são os grupos biológicos na seção ornitológica do British Museum, apresentando as variadas condições da vida e do modo como as aves constroem e colocam seus ninhos. Distingue-se neste sentido também o Museu de Hamburgo, no qual são notáveis particularmente as preparações de animais marinhos, expostos de um modo muito elegante em aquários artificiais. Muito instrutivas são também as preparações de insetos, mostrando o ciclo biológico das diversas espécies, o dimorfismos dos sexos, estações etc., imitações miméticas, os estragos causados à vegetação e especialmente às plantas cultivadas, por insetos nocivos. Particularmente lisonjeira, neste sentido, é a impressão que tive nos Museus de Estrasburgo e Paris. Em geral todos os grandes Museus que visitei, têm ligado grande atenção aos melhoramentos neste sentido, como também se esforçam por dar rótulos mais explicativos, por vezes com informações minuciosas e pequenos mapas, ilustrando a distribuição geográfica de certos gêneros, famílias, etc. ${ }^{255}$

Fundamental para esses "melhoramentos" pelos quais vinham passando as exposições dos museus de História Natural foi a sofisticação das técnicas taxidérmicas. O desenvolvimento de uma taxidermia artística, capaz de conferir ilusão de vida aos animais, foi assinalado por lhering quando se refere ao que chama de método plástico: "Também o método plástico da preparação dos vertebrados tem contribuído muito para tornar mais naturais, mais elegantes e artísticas as cenas da vida animal que representam." ${ }^{256}$

O próprio Ihering nos explica, em artigo jornalístico no qual trata de alguns melhoramentos que vinham sendo feitos no Museu, o que era o método plástico:

(...) o belo exemplar de lobo, há pouco gentilmente oferecido pelo Jardim Público, foi preparado pelo dr. João L. Lima, segundo o moderno sistema taxidérmico, denominado 'método plástico'. Pode-se avaliar bem a vantagem deste método quando se sabe que, ao contrário do que se fazia antigamente, enchendo o couro de qualquer maneira, hoje o couro

\footnotetext{
museus do velho continente. A autora insere tais viagens, e os relatos que a elas se seguiam, numa "tradição de viagens e comentários", prática comum entre diretores de museus. Ver LOPES, Maria Margaret, op. cit., 1997, p. 224, pp. 242-247 e pp. 285-288. Aranha também examina viagens desse tipo efetuadas por diretores do Museu Nacional. O autor indica a importância desse gênero de viagem (que chama de "viagem de ilustração museográfica" ou "grand tour museográfico"), bem como da produção textual que a ela se seguia: a visita às exposições dessas instituições modelares servia de base para projetos de reforma das exposições dos museus de origem dos viajantes. Ver ARANHA FILHO, Jayme Moraes, op. cit., 2011, pp. 15-26.

${ }^{255}$ IHERING, Hermann von. A organização actual e futura dos museus de historia natural. Revista do Museu Paulista, 7, 1907, p. 436.

${ }^{256}$ Ibidem, pp. 436-437.
} 
representa apenas o revestimento que cobre o modelado, sobre massa, do animal, de cujo corpo é assim a representação plástica perfeita. ${ }^{257}$

O método plástico referido por lhering corresponde ao termo alemão Dermoplastik, utilizado para designar essa nova técnica de preparação de animais para exposições zoológicas. Conforme lembra Nyhart, o termo alemão Plastik pode significar "escultura". ${ }^{258} \mathrm{O}$ método plástico referido por Ihering designa, portanto, a técnica em que primeiro se faz um modelo do corpo do animal com uma massa plástica, como gesso ou argila, para depois se cobrir esse manequim com uma pele natural. Essa técnica, diferentemente do mero preenchimento da pele com palha ou material similar, permitia que os preparados adquirissem um aspecto vivo, conferindo verossimilhança aos espécimes expostos. A técnica requeria, todavia, o domínio de conhecimentos científicos (de anatomia e fisiologia de músculos e tendões) e técnicas artísticas (desenho e modelagem) mais precisos por parte do preparador. $^{259}$

Outro aspecto central dessas renovações expositivas foram os chamados grupos biológicos - conjuntos de espécimes animais apresentados coletivamente, de forma a evidenciar relações entre os indivíduos tais como elas ocorreriam na natureza. Ihering também dá destaque ao tema em seu relato de viagem:

Um progresso notável, que data dos últimos decênios, é a exposição de preparações biológicas, de grupos naturais de animais, destinados a ilustrar seu modo de viver. Como o novo sistema do Jardim Zoológico de Hagenbeck apresenta reunidos os diversos animais, que vivem numa determinada zona e sob as mesmas condições físicas e biológicas, assim procura-se hoje exibir grupos biocenóticos de animais de certas regiões bem caracterizadas, como da zona ártica, dos Alpes, do Sertão, etc. e do mesmo modo procedem atualmente, e com admirável sucesso, os Jardins Botânicos. $^{260}$

\footnotetext{
${ }^{257}$ IHERING, Hermann von. Museu do Estado. O Estado de S. Paulo, 06/09/1912, p. 6.

${ }^{258}$ NYHART, Lynn K, op. cit., 2009, pp. 65-66.

${ }^{259}$ Ver KöSTERING, Susanne, op. cit., 2003, pp. 153-154 e pp. 160-162. Nesta dissertação, por vezes os termos "taxidermia" e "montagem" são utilizados de forma genérica, ou seja, referem-se aos vertebrados preparados para exposição, independentemente da técnica utilizada ("método plástico" ou técnicas anteriores).

260 IHERING, Hermann von. A organização actual e futura dos museus de historia natural. Revista do Museu Paulista, 7, 1907, p. 436.
} 
Ainda segundo Ihering: "Tais grupos naturais são muito mais atrativos e instrutivos do que as séries uniformes de animais isolados, que geralmente enchem as vitrinas."261

O diretor ressalva, porém, que se deve ter cuidado na montagem de tais grupos, pois a reconstrução artística de um cenário considerado natural não deveria ser fantasiosa:

Expondo-se uma preparação artística, representando diversos indivíduos, sexos, etc. de uma espécie, é natural que se dê também ao quadro um aspecto natural, imitando um pouco o meio físico no qual passa a vida dos respectivos animais. Acontece, entretanto, que às vezes o artista então procede com fantasia exagerada. ${ }^{262}$

Advertindo para que o cenário artisticamente elaborado não sobreponha os próprios animais, menciona o caso de um grupo de orangotangos do Museu de Altona, cuja visualização era difícil tendo em vista a vasta folhagem que cobria os animais com o intuito de exibi-los no contexto de seu ambiente natural. ${ }^{263}$

Ou seja, Ihering mostrava-se favorável à exposição de animais em poses dinâmicas, que reproduzissem seus comportamentos considerados naturais, de preferência expostos em grupos com cenários, representando seus habitats naturais e seus modos de viver (apesar de advertir contra os exageros artísticos), ao invés de séries organizadas exclusivamente segundo o lugar de cada espécie no sistema taxonômico.

Em suma, o diretor do Museu Paulista pôde observar, em sua viagem, como as exposições dos museus de História Natural vinham de fato se modificando a partir do final do século XIX. O que se relaciona não só com as mudanças nos paradigmas das ciências naturais no período (ascensão da Biologia, da Biogeografia e da Ecologia), mas também com o fato de os museus estarem se preocupando mais com o público.

De acordo com Kohler, o desenvolvimento de exposições mais elaboradas, envolvendo grupos de animais em poses mais dinâmicas e em cenários que

\footnotetext{
261 Ibidem, p. 437.

262 Ibidem, p. 437.

${ }^{263}$ Ibidem, p. 437.
} 
reproduzem seus habitats naturais (o que teria seu auge nos grandes dioramas), foi o principal responsável pelo grande desenvolvimento atingido pelos museus de História Natural americanos no início do século XX. As exposições espetaculares atraíam não só visitantes como também patrocinadores. Dessa forma, os museus teriam passado de centros mais dedicados à pesquisa e guarda de acervos a instituições que atraíam grande volume de público (e de dinheiro de patrocinadores). ${ }^{264}$

No caso dos museus de História Natural alemães, diversas inovações expositivas foram implantadas entre o final do século XIX e o princípio do XX. De modo geral, conforme Köstering, essas exposições passaram por uma virada biológica. Isto é, passaram a ser desenvolvidas soluções expográficas visando acentuar aspectos do comportamento, dos modos de vida e das inter-relações animais. $^{265}$

Particularmente os chamados grupos biológicos vinham ganhando espaço nos museus europeus em torno da virada do século. Segundo Nyhart, tais grupos entendidos como um conjunto de animais apresentados coletivamente, de modo a representar uma cena considerada natural - poderiam variar de uma unidade familiar próxima do ninho ou toca, um habitat com os animais considerados característicos ou mesmo predadores perseguindo uma presa. ${ }^{266}$ Conforme a autora, essas novas soluções expositivas refletiam um novo foco sobre o animal vivo e suas relações funcionais com o resto da natureza. ${ }^{267}$

Como vemos, o Museu Paulista estava atento às modificações nos métodos de exposição que estavam ganhando os museus europeus e de outras partes do mundo naquele período. As exposições dos museus de História Natural vinham se tornando cada vez mais elaboradas a partir da segunda metade do século XIX, e os museus brasileiros, conectados às instituições estrangeiras congêneres não só no

\footnotetext{
${ }^{264}$ KOHLER, Robert E. All Creatures: Naturalists, Collectors, and Biodiversity, 1850-1950. Princeton: Princeton University Press, 2006, pp. 76-82 e pp. 107-117.

${ }^{265}$ KöSTERING, Susanne, op. cit., 2003.

${ }^{266}$ Nyhart insere o desenvolvimento dos grupos biológicos nos museus alemães no contexto da ascensão da perspectiva biológica no âmbito das ciências naturais daquele país a partir da segunda metade do século XIX. A biological perspective é entendida pela autora como um modo de ver a natureza, o qual enfatiza as relações animais entre si e com o meio físico. NYHART, Lynn K, op. cit., 2009.

${ }^{267}$ NYHART, Lynn K, op. cit., 2009, p. 251.
} 
que tange as teorias e práticas científicas, mas também a expografia, procuravam renovar suas soluções expositivas.

Maurício Cândido da Silva examina o desenvolvimento dessas concepções expográficas (exposição dos animais junto a representações de seus ambientes naturais) décadas mais tarde no Museu de Zoologia - instituição criada em 1939, quando se decidiu que a área de Zoologia deveria ser separada do Museu Paulista. ${ }^{268}$ Contudo, como vemos, pequenas inovações expositivas já vinham sendo esboçadas no Museu Paulista dirigido por Ihering. Conforme já apontamos, em meio ao arranjo geral taxonômico, por vezes apareciam outros princípios organizativos guiando algumas exposições do Museu.

\subsection{Novos espécimes, novos discursos}

Ihering pôde, então, conferir de perto as mudanças pelas quais vinham passando os museus de História Natural europeus. Cabe agora examinar até que ponto isso se traduziu em mudanças nas exposições do Museu Paulista. Iremos então examinar as incorporações de peças novas às exposições, para depois nos debruçarmos sobre mudanças nas técnicas taxidérmicas e sobre as tentativas de elaboração de grupos biológicos para as exposições.

Embora a distribuição das diferentes coleções ao longo do andar dedicado às exposições públicas não tenha sofrido alterações substanciais, a gama de objetos ali expostos passou por algumas modificações. Mesmo que os documentos não sugiram a ocorrência de mudanças muito drásticas no panorama geral das exposições, ocorreram, ao menos, incorporações e rearranjos.

É verdade que a falta de espaço restringia a possibilidade de empreender grandes modificações nas coleções expostas. Ihering lamentava que, apesar da longa fachada, o edifício tinha pouca profundidade e, além disso, parte considerável da superfície era constituída por áreas de circulação. Com essa restrição de espaço, ampliar o volume de material exposto, segundo o diretor, seria tarefa difícil: "Assim é

${ }^{268}$ Ver SILVA, Maurício Cândido da, op. cit., 2006, pp. 174-179. 
que o primeiro andar chega por ora para as coleções expostas, mas não oferece o espaço necessário para o desenvolvimento futuro das coleções." 269

Desse modo, não foram abertas novas salas de exposição ao longo da gestão Ihering. A não ser por uma das salas de História Pátria e pela sala dedicada aos insetos, que ainda não estavam prontas para serem abertas ao público quando da inauguração do Museu, em 1895. ${ }^{270}$ Essas foram inauguradas na segunda metade de 1896, como informa O Estado de S. Paulo:

\begin{abstract}
Por todo o mês de agosto devem ser franqueadas ao público mais duas salas, uma de mobílias e objetos históricos e outra de insetos, onde será apreciada uma esplêndida coleção de borboletas e um armário com vespeiros, que representa uma especialidade nossa e dá ideia das preciosidades que nesse gênero possuímos. ${ }^{271}$
\end{abstract}

Mas, mesmo com essas restrições espaciais, e mesmo sem a inauguração de novas salas, algumas mudanças foram introduzidas ao longo da gestão. Embora a documentação pesquisada não apresente muitas informações quantitativas, espécimes foram incorporados às coleções expostas ao longo dos anos em que Ihering esteve à frente do Museu, o que implicava, por vezes, no rearranjo de algumas coleções, incluindo a incorporação de novas vitrines.

Sabe-se que, em 1897, um número significativo de espécimes foi acrescentado às coleções de exposição, tanto materiais preparados pelo taxidermista do Museu, quanto espécimes comprados já taxidermizados. O então preparador do Museu, Hellmuth Pinder, taxidermizou 21 mamíferos, 77 aves e 10 peixes, entre outros, para serem expostos ao público - além de diversos outros espécimes para as coleções de estudo. As exposições também foram enriquecidas

\footnotetext{
269 IHERING, Hermann von. Historia do Monumento do Ypiranga e do Museu Paulista. Revista do Museu Paulista, 1, 1895, p. 30. Talvez se tratasse menos de falta de espaço do que de privilegiar os trabalhos com as coleções de estudo em detrimento das exposições. Afinal, logo no início da gestão Taunay, em 1917, são inauguradas duas novas salas no piso térreo: uma dedicada à Botânica e outra à história de São Paulo. Ver MUSEU Paulista - inauguração de uma sala em que figuram colecções botanicas. Correio Paulistano, 05/09/1917, p. 2; MUSEU Paulista. Correio Paulistano, 24/12/1917, p. 2; e Brefe, Ana Cláudia Fonseca. O Museu Paulista: Affonso de Taunay e a memória nacional, 1917-1945. São Paulo: Unesp/Museu Paulista, 2005, pp. 97-101. Originalmente Tese (Doutorado) defendida no Instituto de Filosofia e Ciências Humanas da Universidade Estadual de Campinas em 1999.

270 IHERING, Hermann von. Historia do Monumento do Ypiranga e do Museu Paulista. Revista do Museu Paulista, 1, 1895, p. 20.

${ }^{271}$ MUSEU Paulista. O Estado de S. Paulo, 11/07/1896, p. 1.
} 
por objetos comprados: 16 mamíferos, 33 aves, 10 jacarés, cágados e lagartos, entre outros. $^{272}$

Possivelmente, parte considerável dos exemplares comprados que foram incorporados às exposições provinha da já mencionada coleção de objetos amazonenses comprada de Carneiro Leão, o qual havia empreendido anteriormente a exposição de tais animais em São Paulo. ${ }^{273}$ Em relatório referente ao ano de 1897, Ihering menciona detalhadamente tal compra, informando inclusive que os peixes adquiridos eram todos empalhados - o que nos permite concluir que tiveram como destino as coleções expostas ao público, e não as coleções de estudo, onde era mais usual armazenar esse tipo de material em via úmida (vidros com álcool). Conforme Ihering:

\begin{abstract}
Por meio de compra foram adquiridos numerosos objetos de grande interesse. Refere-se isso em primeiro lugar à coleção de animais do Amazonas que foram comprados ao sr. Carneiro Leão, que algum tempo expôs nessa capital um Museu amazônico, vendendo parte dele ao do Estado pelo preço de rs. 3:500\$000. Entre esses objetos merecem menção o bonito e grande peixe Pirarucu e vários outros peixes todos empalhados, diversos jacarés entre eles três espécies até então não representadas nas coleções do Museu, o cágado do Amazonas e diversos mamíferos e aves que faltavam às nossas coleções. ${ }^{274}$
\end{abstract}

Outro documento informa que, em 1911, a coleção exposta ganhou, em substituição a peças consideradas mal empalhadas, 6 mamíferos e 78 aves, além de outros animais não contabilizados. ${ }^{275}$

Apesar de não termos números que permitam delinear com precisão o volume de espécimes incorporados às exposições nos demais anos, temos algumas informações qualitativas às quais vale a pena dar destaque.

O jornal $O$ Estado de $S$. Paulo informa sobre a aquisição de duas peças chamativas em 1896: "Foram ultimamente adquiridos um exemplar de condor do

\footnotetext{
${ }^{272}$ IHERING, Hermann von. O Museu Paulista no anno de 1897, Revista do Museu Paulista, 3, 1898, p. 13.

${ }^{273}$ Ofíclo [de Hermann von Ihering] ao Secretário do Interior, São Paulo, 04/03/1897. APMP/FMP, Série Correspondência.

${ }^{274}$ IHERING, Hermann von. O Museu Paulista no anno de 1897, Revista do Museu Paulista, 3, 1898, p, 11.

${ }^{275}$ IHERING, Hermann von. Museu do Estado. O Estado de S. Paulo, 06/09/1912, p. 6.
} 
Andes, que mede quase o duplo do nosso urubu-rei, e um da grande aranha do mar do Japão - Macrocheira kaempferi - que mede 3,15m." 276

Ihering destaca, no ano de 1897, a incorporação de um pinguim bem empalhado às coleções expostas. ${ }^{277}$ Já no relatório referente ao ano de 1898 , 0 diretor informa sobre outras duas novidades nas exposições: uma coleção de amostras de mármore provenientes de Itupararanga, perto de Sorocaba, doada pelo Banco União de S. Paulo; e um gavião de penacho, Thrasaetus harpyia L., doado ao museu pelo Sr. Mario Rodrigues, de São José do Rio Pardo, que passou a ser exposto em cima da vitrine das aves de rapina. ${ }^{278}$

Em 1900, conseguiu-se uma nova harpia, desta vez viva, que foi exposta numa gaiola no pavimento inferior do monumento, "tornando-se um ponto de grande atração dos visitantes”. Dois funcionários do Museu, C. Schrottky, zelador, e João Leonardo Lima, então servente e futuramente preparador, foram enviados ao município de Caconde para buscar a ave viva, presente de José Umbelino Fernandes. $^{279}$ Além disso, entre 1899 e 1900 foi reformada e ganhou novas legendas a exposição de ninhos e ovos de aves. ${ }^{280}$

Em 1905, ocorreram a renovação das peças de cervídeos e a incorporação de dois espécimes de peixe-boi provenientes do rio Juruá. Esses peixes-boi, segundo Rodolpho von Ihering, vinham despertando especial interesse do público, por se tratar de animais curiosos, os quais inclusive teriam ocorrido no litoral de São Paulo no período colonial. ${ }^{281}$

\footnotetext{
${ }^{276}$ MUSEU Paulista. O Estado de S. Paulo, 11/07/1896, p. 1.

${ }^{277}$ IHERING, Hermann von. O Museu Paulista no anno de 1897, Revista do Museu Paulista, 3, 1898, p, 11.

${ }^{278}$ IHERING, Hermann von. O Museu Paulista no anno de 1898, Revista do Museu Paulista, 4, 1900, pp. 3-4.

${ }^{279}$ IHERING, Hermann von. O Museu Paulista em 1899 e 1900. Revista do Museu Paulista, 5, 1902, pp. 2-3; Os MUNicíPIOS. O Estado de S. Paulo, 19/05/1900, p. 1; Os MUNIcíPIOs. O Estado de S. Paulo, 21/05/1900, p. 1. Expor alguns poucos animais vivos em gaiolas não era exclusividade do Museu Paulista. Décadas antes, o Museu Nacional já contava com uma harpia viva, além de um urubu-rei e uma jiboia em gaiolas no pátio do edifício. Ver LOPES, Maria Margaret, op. cit., 1997, p. 97 e p. 133. A posição de destaque dada à harpia no Museu Paulista, e também em outros museus do país (tratavase da ave símbolo do Museu Nacional), pode ser atribuída ao peso semântico imbricado no fato de ser ela a maior ave de rapina do Brasil.

${ }^{280}$ IHERING, Hermann von. O Museu Paulista em 1899 e 1900. Revista do Museu Paulista, 5, 1902, p. 6.

${ }_{281}^{6}$ IHERING, Rodolpho von. O Museu Paulista nos annos de 1903 a 1905. Revista do Museu Paulista, 7, 1907, pp. 12-13.
} 
Ainda no ano de 1905, a seção de mamíferos ganhou um material importante: uma nova vitrine de primatas (figura 13), na qual, conforme já aludimos antes, os espécimes eram organizados zoogeograficamente. Conforme Rodolpho von Ihering:

\begin{abstract}
Devemos destacar em especial os trabalhos realizados na seção de Mamíferos, onde foi inaugurado um grande e belo armário duplo, com uma separação interna no sentido longitudinal, de vidro fosco, que corresponde excelentemente ao fim de iluminar melhor o lado interno do armário, sem que contudo os exemplares do outro lado distraiam a atenção do observador. Foram aí expostos unicamente os Símios brasileiros, sendo que de um lado estão os macacos do Brasil meridional (nessa representação 39 espécimes) e de outro lado os da região Amazônica (28 espécimes, quase todos coligidos pelo nosso naturalista-viajante em sua exploração do Rio Juruá). ${ }^{282}$
\end{abstract}

A inauguração dessa nova vitrine é inclusive noticiada pelo Correio Paulistano. O jornal destaca que ela chamava a atenção do público e que todas as espécies de macacos do Brasil meridional estavam ali representadas:

Na sala dos mamíferos é agora em especial o novo armário duplo dos Primatas, que chama a atenção do público, visto como, montado com capricho, encerra, de um lado a representação completa dos macacos do Estado de S. Paulo e do Brasil meridional, enquanto que na metade oposta figura uma belíssima série de macacos da Amazônia, todos estes novos e bem preparados. Há entre estes últimos, tipos muitíssimo curiosos e característicos para a fauna do nosso país. ${ }^{283}$

Entre os anos de 1906 e 1909, foram comprados peixes provenientes de ilhas do litoral paulista empalhados por Francisco Günther. Além disso, ampliou-se o número de corais expostos ao público, já que foi realizada a "compra de uma série de belíssimas peças da casa Ward."284

Outras compras para as coleções expostas foram realizadas nesse período. No princípio de 1907 foi adquirida, da casa comercial Staudinger \& Bang-Haas, "uma coleção de belíssimos coleópteros raros, para a coleção exposta no Museu". ${ }^{285}$ No

\footnotetext{
${ }^{282}$ IHERING, Rodolpho von. O Museu Paulista nos annos de 1903 a 1905. Revista do Museu Paulista, 7, 1907, pp. 12-13.

${ }^{283}$ MUSEU Paulista. Correio Paulistano, 27/12/1905, p. 3.

${ }^{284}$ IHERING, Hermann von; IHERING, Rodolpho von. O Museu Paulista nos annos de 1906 a 1909. Revista do Museu Paulista, 8, 1911, pp. 6-7 e p. 12.

${ }^{285}$ REGISTRO em livro de aquisições, jan./1907. APMP/FMP, Série Relações de aquisições.
} 
ano seguinte comprou-se, do comerciante alemão W. Schlüter, "uma coleção de 38 beija-flores escolhidos dos mais belos, para empalhar". ${ }^{286}$ Como vemos, as redes de caçadores e negociantes de produtos de História Natural às quais o Museu estava atrelado, além de espécimes para as coleções científicas, por vezes também forneciam materiais para as exposições do Museu - peças particularmente chamativas, de acordo com os adjetivos usados para descrever os corais, beijaflores e borboletas adquiridos. ${ }^{287}$

Além desses espécimes zoológicos, temos incorporações de artefatos históricos, arqueológicos e etnográficos.

Em 1905, as exposições de Arqueologia e de História Pátria receberam novas vitrines e novas peças. No caso da História Pátria, foi instalada uma vitrine contendo bandeiras, espadas, a armadura de Martim Afonso de Souza, entre outros objetos, além de uma vitrine dedicada a expor a coleção Campos Sales. ${ }^{288}$ Quanto à Arqueologia, passaram a ser expostas peças provenientes de Amargosa, Bahia, adquiridas de Christovam Barreto, e do Rio Grande do Sul, adquiridas de Arnaldo Barbedo. ${ }^{289}$

Entre os anos de 1906 e 1909, foi montada uma nova vitrine com peças etnográficas dos índios Coroados ou Caingangues que habitavam o oeste paulista. Tal material havia sido coligido pela Comissão Geográfica e Geológica do Estado de São Paulo, durante suas incursões pelo interior do estado, e doado ao Museu. ${ }^{290}$

Entre os anos de 1910 e 1912 houve reformulações nas exposições de Arqueologia e Etnologia. Quatro vitrines novas foram instaladas na galeria do

\footnotetext{
${ }^{286}$ REGISTRO em livro de aquisições, 03/07/1908. APMP/FMP, Série Relações de aquisições.

${ }^{287}$ Uma carta da Casa Ward, do Estado Unidos, indica a existência de interesse por parte do Museu na compra de animais montados, para exposições. Em carta de 1906, a Casa Ward informa (provavelmente por pedido de Ihering) que possuía amplo sortimento de aves e mamíferos sulamericanos, mas nenhum peixe. Apresenta uma lista dos mamíferos montados que possuía, com respectivos preços, e informa que as aves eram tantas que seria impossível listar - pede então que Ihering informe primeiro quais aves gostaria de adquirir, para que ele possa lhe dar os preços das taxidermias. CARTA de Ward's Natural Science Establishment, em inglês, a Hermann von Ihering, Rochester, 23/04/1906. APMP/FMP, Série Prestação de contas.

288 IHERING, Rodolpho von. O Museu Paulista nos annos de 1903 a 1905. Revista do Museu Paulista, 7, 1907, pp. 13-14; MUSEU Paulista. Correio Paulistano, 27/12/1905, p. 3.

${ }^{289}$ IHERING, Rodolpho von. O Museu Paulista nos annos de 1903 a 1905. Revista do Museu Paulista, 7, 1907, pp. 13-14; MUSEU Paulista. Correio Paulistano, 27/12/1905, p. 3.

${ }^{290}$ IHERING, Hermann von; IHERING, Rodolpho von. O Museu Paulista nos annos de 1906 a 1909. Revista do Museu Paulista, 8, 1911, pp. 6-7 e p. 12. Sobre a Comissão Geográfica e Geológica, ver FIGUEIRÔA, Silvia Fernanda de Mendonça, op. cit., 1987; e FIGUEIRÔA, Silvia Fernanda de Mendonça, op. cit., 1997, pp. 187-216.
} 
pavimento dedicado às exposições públicas. Tais vitrines continham: artefatos de pedra e de cerâmica "dos nossos índios"; objetos de pedra da cultura Calchaquí (originais e cópias), obtidos em permuta com museus argentinos; e objetos incas adquiridos por intermédio de Max Uhle. ${ }^{291}$ A instalação das coleções arqueológicas nas quatro vitrines da galeria permitiu o rearranjo das coleções etnográficas: na sala de Etnografia, uma vitrine passou a abrigar exclusivamente artefatos dos índios do estado de São Paulo, enquanto as demais continham peças pertinentes às demais etnias do país. ${ }^{292}$ Além disso, surgiu espaço para que fossem exibidas "as belas e ricas coleções dos artefatos dos índios Botocudos do rio Doce e dos Tucanos do rio Uaupeu, afluente do rio Negro."293

Embora o Museu não tenha abrigado, durante o período abrangido por este estudo, novas soluções expositivas no âmbito das coleções etnográficas, Ihering desenvolveu, para a Seção de Etnografia do Estado de São Paulo na Exposição Nacional do Rio de Janeiro, em 1908, montagens incluindo modelos de indígenas em tamanho real, como se fazia na Europa. Elaborados pelo alemão Bruno Zwarg, professor de desenho e modelagem na Escola Normal de São Paulo, os modelos de indígenas (Chavantes, Coroados e Caiuás) foram dispostos, de modo a compor cenas, em ambientes que procuravam recriar o que seriam os locais de habitação das etnias. ${ }^{294}$ Por essa exibição etnográfica, o Museu recebeu o Grande Prêmio da Exposição de $1908 .^{295}$

Além disso, em 1914, o Museu inaugurou a exposição de uma coleção, doada pelo Ministério da Agricultura, de "amostras de borracha, dos respectivos artefatos, bem como dos diversos apetrechos e materiais". A inauguração, realizada no salão de Honra do Museu, contou com uma conferência de Hermann von Ihering sobre a indústria da borracha. ${ }^{296}$

291 Friedrich Maximiliano Uhle Lorenz (1856-1944) foi um arqueólogo alemão que desenvolveu importantes trabalhos sobre a Arqueologia sul-americana.

292 [IHERING, Hermann von]. O Museu Paulista nos annos de 1910, 1911 e 1912. Revista do Museu Paulista, 9, 1914, p. 9; IHERING, Rodolpho von. Museu Paulista - a Seção Etnográfica. O Estado de S. Paulo, 15/07/1910, p. 5.

${ }^{293}$ Museu Paulista. O Estado de S. Paulo, 03/07/1910, p. 5.

294 Ver BARBUY, Heloisa, op. cit., 2002, pp. 68-70; Ofíclo de Hermann von Ihering ao Secretário do Interior, São Paulo, 15/07/1908. APMP/FMP, Série Correspondência; Ofícıo de Hermann von Ihering a Carlos Botelho, representante do Governo de São Paulo na Exposição Nacional, São Paulo, 24/07/1908. APMP/FMP, Série Correspondência.

${ }^{295}$ Ver LOPES, Maria Margaret, op. cit., 1997, p. 279.

${ }^{296}$ EXPOSIÇÃO de borracha no Museu Paulista. Correio Paulistano, 16/01/1914, p. 3. 


\title{
3.3.1. Do empalhamento ao método plástico
}

Mais do que ampliar o volume de peças expostas, as incorporações e modificações nas exposições almejavam aprimorar a qualidade do material exibido e sofisticar as temáticas e soluções expositivas. Um ponto importante, no que tange as coleções zoológicas, é a questão da substituição dos exemplares considerados feios, velhos ou mal preparados. O assunto aparece recorrentemente nos relatórios do Museu publicados na Revista, seja figurando apenas como objetivo a ser alcançado pela instituição, seja como relato de substituição de algumas peças. ${ }^{297}$

Afinal, segundo Ihering, esses espécimes feios ou mal preparados faziam com que o Museu fosse alvo de críticas. Segundo o diretor:

\begin{abstract}
(...) [as coleções do Museu] têm um grande defeito, que é serem muitas das espécies da nossa fauna representadas por espécimes imperfeitos e alguns mui mal preparados. Esses defeitos resultantes do fato de serem esses espécimes mal empalhados, têm dado lugar a críticas, sendo então pouco lisonjeiras as opiniões emitidas.
\end{abstract}

É portanto, de grande conveniência substituir-se as preparações velhas e pouco decentes, por outras feitas com arte e capricho e, neste sentido, já reclamei o auxilio do Governo (.... $)^{298}$

É possível que muitos desses espécimes considerados velhos, feios ou mal preparados fossem provenientes do antigo Museu Sertório. Afinal, em 1912, das 965 aves empalhadas expostas no Museu Paulista, 525 eram remanescentes da Coleção Sertório - sendo que, quando passou para a administração pública, tal coleção (possivelmente somada à coleção Pessanha) possuía 1.600 espécimes de aves (de 400 espécies). Quanto aos mamíferos, dos 430 espécimes empalhados (de 90 espécies) existentes na coleção antiga (Sertório e possivelmente Pessanha)

\footnotetext{
297 IHERING, Hermann von. Historia do Monumento do Ypiranga e do Museu Paulista. Revista do Museu Paulista, 1, 1895, pp. 21; IHERING, Hermann von. O Museu Paulista no anno de 1896. Revista do Museu Paulista, 2, 1897, p. 7; IHERING, Hermann von. O Museu Paulista no anno de 1897. Revista do Museu Paulista, 3, 1898, p, 9; IHERING, Hermann von. O Museu Paulista em 1899 e 1900. Revista do Museu Paulista, 5, 1902, p. 7; IHERING, Hermann von; IHERING, Rodolpho von. O Museu Paulista nos annos de 1906 a 1909. Revista do Museu Paulista, 8, 1911, pp. 6-7; [IHERING, Hermann von]. O Museu Paulista nos annos de 1910, 1911 e 1912. Revista do Museu Paulista, 9, 1914, p. 9.

${ }^{298}$ IHERING, Hermann von. O Museu Paulista em 1899 e 1900. Revista do Museu Paulista, 5, 1902, p. 7.
} 
quando ela foi doada ao estado, 105 ainda permaneciam no Museu em 1912. Outros 186 mamíferos empalhados foram incorporados às exposições do Museu Paulista entre 1896 e $1912 .^{299}$

Mesmo ao fim da gestão Ihering, ainda permaneciam em exposição diversos exemplares remanescentes da Coleção Sertório. Quando Taunay assumiu a direção do Museu, em 1917, ele informou, em relatório ao Secretário do Interior, que pretendia substituir tais peças, tendo vista seu aspecto desagradável:

Nas vitrinas figuram numerosos espécimes que pertenceram ao antigo Museu Sertório e estão sumamente avariados, causando-Ihe o aspecto muito má impressão ao público. Resolvi que o taxidermista substitua todos estes exemplares $(\ldots)^{300}$

Para além do fato de estarem "avariados", ou gastos pelo tempo, parece-nos que o modo de empalhamento dos animais da Coleção Sertório não devia atender às expectativas de um museu que se queria moderno. $O$ fato de parecerem feios significava que não cumpriam o objetivo de fazer com que o visitante pudesse experimentar a sensação de estar diante do animal real.

No seu intuito de possibilitar uma visualização da natureza, as exposições dependiam, em primeiro lugar, de espécimes bem montados, isto é, de montagens taxidérmicas que guardassem larga semelhança com a aparência do animal real, a ponto de não provocar um estranhamento no visitante. Afinal, uma taxidermia malfeita seria desastrosa, causando repulsa, ou risos, ao invés de propiciar uma imagem da natureza. Segundo Alberti: "A well-crafted mount in a plush diorama is one thing, but visibly poor stitching and bulbous glass eyes are the stuff of horror movies."301

A finalidade da taxidermia seria, ao produzir modelos que reproduzem 0 formato do animal vivo e que são revestidos de peles autênticas, possibilitar a experiência mais próxima possível daquela que se teria diante do animal vivo. As

\footnotetext{
${ }^{299}$ LISTAGEM de espécimes empalhados existentes no Museu Paulista. 17/07/1912. APMP/FMP, Série Correspondência; e Hummel, Alexandre. Primeiro Relatório sobre as atuais condições do Museu do Estado, apresentado ao diretor do mesmo por Alexandre Hummel, ajudante interino. São Paulo, Outubro de 1891, p. 5 e p. 11. Museu Paulista, Coleção Harold Alexandre Hummel.

300 [TAUNAY, Affonso de E.]. Relatório dirigido ao Secretário do Interior. São Paulo, 10/03/1917. APMP/FMP, Dossiê Comissão de Sindicância sobre a gestão de Hermann von Ihering.

${ }^{301}$ ALBERTI, Samuel J. M. M. (org.), op. cit., 2011, p. 8.
} 
montagens taxidérmicas podem ser entendidas, dessa forma, como simulacros. Conforme Garry Marvin:

In an important and significant sense, the taxidermied mount is only a superficial animal; it is only, literally, skin-deep, but that surface must be crafted to convey a sense of the whole. In this sense, each can also be considered as simulacrum, as 'a thing having the appearance but not the substance or proper qualities of something,' that is attempting to convey those proper qualities of the original. ${ }^{302}$

Conforme Barbuy - analisando outro tipo de material e em outro contexto, mas em raciocínio que acreditamos possa ser estendido para o exame das montagens taxidérmicas -, a materialidade é aspecto fundamental para o sucesso de simulacros dessa ordem. Conforme a autora: “(...) a matéria é em si realidade sensorialmente apreensível e essa sua característica intrínseca é que a faz substância ideal para a construção de irrealidades realísticas." ${ }^{303} \mathrm{O}$ fato de tais modelos (taxidermias) serem tridimensionais e palpáveis é fundamental para que possam ser experimentados como se fossem seus referentes (o animal vivo). À sua materialidade, devemos acrescentar a autenticidade da pele, que é justamente a parte do animal que é primeiramente apreensível pela visão.

Nesse sentido de tentar expor animais tal como se estivessem vivos ou fossem reais é que as montagens taxidérmicas se tornaram os principais objetos expostos nos museus de História Natural, em detrimento de outras possibilidades, as quais, embora continuassem a existir, tornaram-se menos comuns - por exemplo, expor animais inteiros conservados em vidros com álcool. Conforme Alberti: "The most complete animals are to be found submerged in preservative fluid, but these 'wet' specimens are often considered insufficiently palatable for display (...)". ${ }^{304}$

Consciente do papel fundamental da taxidermia "bem-feita" para que os visitantes pudessem "ver" a natureza, o Museu Paulista se preocupava com a elaboração de espécimes bem montados, bonitos, capazes de atrair o visitante e

\footnotetext{
${ }^{302}$ MARVIN, Garry. "Enlivened through memory: hunters and hunting trophies." In: ALBERTI, Samuel J. M. M. (org.). The Afterlives of Animals: A Museum Menagerie. Charlottesville and London: University of Virginia Press, 2011, p. 213.

${ }^{303}$ BARBUY, Heloisa, op. cit., 1999, p. 123. Para uma análise das noções de "simulacro" e "ilusão" no contexto da cultura visual do séc. XIX, ver Ibidem, pp. 122-131.

${ }^{304}$ ALBERTI, Samuel J. M. M. (org.), op. cit., 2011, p. 8.
} 
possibilitar a ele visualizar o animal tal qual fosse totalmente autêntico. As novas técnicas taxidérmicas, envolvendo a modelagem de um corpo artificial que seria "vestido" com a pele natural, exerciam aí papel fundamental.

Além disso, para além de uma taxidermia bem feita, os espécimes deveriam ser montados em poses dinâmicas, que indicassem movimento. Tratava-se de modelar o animal de forma que aquela montagem taxidérmica expressasse o que se entendia ser a identidade daquela espécie. Esse é o caso dos felinos que podem ser vistos na figura 12, por exemplo. A onça pintada que aparece na parte inferior da vitrine maior apresenta aspecto sorrateiro, como se tivesse se movendo vagarosamente para não espantar a presa - o que é comunicado pela combinação de pata ligeiramente flexionada, cabeça voltada para o lado e parte posterior do tronco em nível mais baixo que a anterior. Já o gato do mato, no canto superior direito, tem as pernas traseiras totalmente flexionas e a cabeça voltada para cima, como se estivesse prestes a saltar sobre a presa. ${ }^{305}$

Garry Marvin, em seu estudo sobre troféus de caça, tendo dialogado com caçadores e taxidermistas, comenta sobre como eles pretendem que o troféu capture o que se considera ser a essência do animal. Nesse sentido, são recusadas montagens taxidérmicas em que o animal pareça exageradamente agressivo. ${ }^{306}$

Os espécimes provenientes da Coleção Sertório, conforme relato do naturalista Alexandre Hummel, não cumpririam tal requisito de capturar o que seria

\footnotetext{
305 Podemos conjecturar que essas poses dos preparados deviam corresponder a modelos que circulavam entre diversos museus e ateliês de taxidermia ao redor do mundo. No caso do Museu Paulista, podemos supor que tais modelos chegassem não só por meio das viagens do diretor e do zelador pela Europa, mas também através da iconografia que deveria estar presente seja em manuais de taxidermia, seja em outros tipos de publicações zoológicas que contivessem ilustrações. As próprias gravuras incluídas no catálogo de mamíferos (carnívoros) elaborado por lhering apresentam animais em posições movimentadas (ver figuras 14 a 16), podendo ser comparadas com os felinos taxidermizados do Museu (figura 12). Tais gravuras, aliás, foram originalmente concebidas para a obra do importante taxidermista alemão Philipp Leopold Martin, Illustrierte Naturgeschichte der Thiere, publicada em Leipzig, Alemanha, no ano 1882, pelo editor F. A. Brockhaus. Os clichês referentes a essas gravuras foram comprados pelo Museu Paulista da própria Brockhaus, em 1910, para ilustrar o catálogo de mamíferos publicado na Revista. Cf. CONTA de F. A. Brockhaus, Leipizig, 23/03/1910. APMP/FMP, Série prestação de contas. Sobre Philipp Leopold Martin (1815-1886) e a importância de suas ideias para a virada biológica nos museus alemães, ver KösTERING, Susanne, op. cit., 2003, pp. 154-177; e NYHART, Lynn K, op. cit., 2009, pp. 35-61 e pp. 92-107. A confecção de ilustrações para a Revista do Museu Paulista envolvia, por diversas vezes, a contratação de serviços gráficos (e, em menor escala, de desenhistas) na Europa, como indica documentação existente no APMP/FMP. Tal assunto, todavia, extrapola a temática desta dissertação - mas poderá ser futuramente investigado.

${ }^{306}$ MARVIN, Garry, op. cit., 2011, pp. 213-214.
} 
considerado a "essência" - ou o comportamento tido como natural ou característico - dos animais. Em 1891, examinando a Coleção Sertório recém-doada ao estado, Hummel reprovava o modo de apresentação das aves:

\begin{abstract}
Quanto aos pássaros pode-se objetar que, sendo em geral bem empalhados, o preparador descurasse algum tanto de lhes dar posições naturais e vivas. Aquelas intermináveis fileiras sugerem a monotonia dum regimento em marcha ou duma grave reunião sem assunto para palestra, de que se vê que as atribuições do perfeito empalhador devem ser múltiplas, e a menor não é esta de ter estudado a natureza. ${ }^{307}$
\end{abstract}

Substituir os espécimes provenientes da Coleção Sertório devia significar, portanto, mais do que trocar peças feias ou gastas, introduzir no Museu peças que correspondessem aos novos ideais taxidérmicos então vigentes: animais propiciando ilusão de movimento, reproduzindo o comportamento que teriam na natureza.

\title{
3.3.2. Grupos biológicos
}

As modificações nas exposições envolviam, para além de novas taxidermias, novas temáticas e novas soluções expositivas. Como vimos anteriormente, as exposições do Museu Paulista, já em 1907, contavam com várias inovações: as exposições de Biologia e de mimetismo dos insetos, de fases da metamorfose da rã, de Zoogeografia de primatas, além de alguns grupos biológicos.

Algo particularmente enfatizado nessas novas soluções expositivas é a questão do comportamento animal. Os beija-flores, por exemplo, foram arranjados tal qual estivessem se alimentando. Por meio da peça de defesa elaborada pelo advogado de Ihering contra as acusações feitas pela comissão encarregada de inspecionar o Museu Paulista, ficamos sabendo que os beija-flores eram expostos

\footnotetext{
307 HUMmel, Alexandre. Primeiro Relatório sobre as atuais condições do Museu do Estado, apresentado ao diretor do mesmo por Alexandre Hummel, ajudante interino. São Paulo, Outubro de 1891, pp. 12-13. Museu Paulista, Coleção Harold Alexandre Hummel.
} 
juntamente com flores artificiais adquiridas pessoalmente por Rodolpho von Ihering no Museu do Louvre, Paris, quando ele esteve na Europa. Segundo o advogado:

\begin{abstract}
(...) se [a comissão encarregada de inspecionar o Museu Paulista] se desse ao trabalho de visitar atentamente a sala $B-1$ do Museu, lá veria uma linda coleção de beija-flores, armados no meio de folhagens com madressilvas, rosas e várias outras flores, das quais simulam estar sugando o mel. Se o diretor do Museu pusesse cada beija-flor pousado estupidamente em um pau seco, a comissão ficaria escandalizada com tanta falta de gosto e desamor à Arte. ${ }^{308}$
\end{abstract}

Tratava-se, portanto, de enfatizar um aspecto do modo de vida, do comportamento do animal: a alimentação. Buscava-se não mais expor apenas peças de um sistema de organização da natureza, mas sim a própria vida dos animais.

Mas a questão do comportamento animal aparece de forma mais nítida na reunião dos preparados em grupos, de modo a demonstrar seus modos de interação. Como vimos, Ihering destaca, em seu relatório de viagem, os grupos biológicos que vinham ganhando as exposições dos museus europeus. No Museu Paulista, foram realizadas algumas iniciativas no sentido de agrupar os animais dessa forma.

Ihering, em trecho de relatório publicado no volume 9 da Revista, informa que, quando possível, as novas peças preparadas pelo taxidermista do Museu para entrar nas exposições eram montadas em grupos:

Desta forma o que se tem feito nas coleções expostas ao público é
substituir os espécimes velhos por outros de preparação nova, os quais,
sendo possível, são montados em grupos, pelo que se torna a observação
mais atraente ao visitante. O preparador, sr. João L. Lima, dedicou boa
parte de seu tempo a esses trabalhos, conseguido assim dar realce a vários

${ }^{308}$ RIBEIRO, Abrahão. Em defesa do Dr. Hermann von Ihering. O Estado de S. Paulo, 15/10/1916, p. 13. O advogado, Abrahão Ribeiro (que assumiu a causa após Reynaldo Porchat ter dela declinado), trata dessas flores porque a conta referente à aquisição das mesmas estava sendo questionada pela comissão de inspeção. A comissão acusava os Ihering de terem usado dinheiro do Museu para comprar flores artificiais para fins particulares. Sobre o processo que culminou na saída de lhering do Museu Paulista (envolvendo acusações de apropriação indevida de coleções do Museu), ver, além desse artigo n'O Estado, as seguintes obras: ALVES, Ana Maria de Alencar, op. cit., 2001, pp. 147153; e GUALTIERI, Regina Cândida Ellero, op. cit., 2008, pp. 103-104. 
armários. Mencionaremos nas salas das aves os armários de beija-flores e das aves aquáticas; o dos pequenos mamíferos, etc. ${ }^{309}$

Em outra oportunidade, Ihering voltou a destacar que as peças deficientes estavam sendo progressivamente substituídas por outras "artisticamente preparadas", as quais, quando possível, eram montadas em grupos. Conforme o diretor:

\begin{abstract}
A coleção de aves do Museu compreende duas seções distintas. No andar superior do edifício, franqueado ao público, figura a coleção de espécimes empalhados; com relação a ela esforçamo-nos por substituir as peças deficientes por espécimes artisticamente preparados $e$ aos quais procuramos dar um agrupamento o quanto possível natural. Essa transformação que não pode deixar de ser lenta, é natural que o público não a perceba; contudo em todas as seções ela progride e tende a um aperfeiçoamento de todas as coleções. A outra seção, inteiramente à parte, formando a coleção de estudos (...) $)^{310}$
\end{abstract}

De fato, como vimos, o Guia nos revela que, nas exposições dedicadas à Ornitologia, duas vitrines contavam com grupos biológicos. Esse é o caso do já citado "grupo biológico da Coruja do Campo onde se os vê reunidos em família em frente ao ninho"311, existente na vitrine dedicada às aves de rapina. Ou do também já mencionado "grupo biológico que mostra a espécie de Marreca (Nettion brasiliense) mais comum nos arredores de São Paulo". ${ }^{312}$ Na figura 5 é possível ver, no canto esquerdo (na primeira e na terceira prateleira), dois grupos de corujas, um dos quais deve corresponder à descrição feita pelo Guia.

Algumas fotografias de pássaros taxidermizados - que muito provavelmente pertenciam às exposições do Museu Paulista - permitem-nos ver igualmente algumas montagens de aves em grupos e em poses movimentadas, que visavam apresentar o que seria o comportamento natural dos animais (figuras 17 e 18). Tais montagens contrastam com outras taxidermias em que o pássaro aparece de forma

\footnotetext{
309 [IHERING, Hermann von]. O Museu Paulista nos annos de 1910, 1911 e 1912. Revista do Museu Paulista, 9, 1914, p. 9.

${ }^{310}$ IHERING, Hermann von. Novas contribuições para a Ornithologia do Brazil. Revista do Museu Paulista, 9, 1914, pp. 413-414.

311 IHERING, Rodolpho von, Guia cit., 1907, p. 88.

312 Ibidem, p. 88.
} 
mais estática (figura 19) - sinal de que o trabalho de renovação das preparações, como havia dito o próprio Ihering, ia se dando aos poucos. ${ }^{313}$

Não se tratava, como vemos nas fotos, de soluções muito espetaculares, como os grandes dioramas que começavam a povoar os museus europeus e norteamericanos. $^{314}$ Já era, todavia, um movimento em direção a novas soluções expositivas, diferentes das "séries uniformes de animais isolados, que geralmente enchem as vitrinas". ${ }^{315}$ Nos casos citados, vemos grupos que representam aspectos dos modos de vida das aves: reprodução, nidificação, assistência ao filhote, etc.

Existem ainda três cartas, endereçadas a lhering, as quais evidenciam que o diretor ao menos cogitou elaborar exposições de grupos biológicos de mamíferos, já que entrou em contato com um preparador alemão para adquirir um "grupo de feras". As duas primeiras cartas são datadas de setembro de 1907, período em que Ihering se encontrava na Europa. Nelas, o taxidermista de Colônia, Heinrich Sander, convida o diretor do Museu Paulista para uma visita ao seu estúdio e informa que, naquele momento, ainda não possuía os couros de animais (onça pintada e suçuarana) necessários para dar início ao trabalho solicitado. ${ }^{316} \mathrm{Na}$ terceira carta, datada de 1912, o emissor afirma que, por algum motivo, não havia sido efetivado o "grupo de feras" a respeito do qual tinham conversado havia cinco anos. Diz então que enviava seu mais recente catálogo, na esperança de receber algum pedido de Ihering. ${ }^{317}$

Tais correspondências estão em papel de carta do ateliê de taxidermia de Heinrich Sander, o "Sander's Präpratorium". O papel de carta apresenta impressas as especialidades desse "Naturhistorisches Institut", entre elas: "Modelagem dermoplástica de animais grandes e muito grandes - macacos e elefantes"; e

\footnotetext{
${ }^{313}$ Tais fotografias constam de artigos de autoria de Rodolpho von Ihering, publicados na Revista Chacaras e Quintaes, nos quais defende a proteção das aves.

${ }^{314} \mathrm{O}$ termo diorama, no caso dos museus de História Natural, refere-se à exposição em perspectiva de animais diante de um painel pintado ao fundo, gerando assim a sensação de profundidade. Ver KöSTERING, Susanne, op. cit., 2003, p. 97. Sobre mecanismos desenvolvidos no séc. XIX com a finalidade de proporcionar novas experiências visuais, ver BARBUY, Heloisa, op. cit., 1999.

${ }^{315}$ IHERING, Hermann von, op. cit., 1907, pp. 436-437.

${ }^{316}$ CARTA, em alemão, com tradução anexa, de H. Sander a Hermann von Ihering, Köln, 04/09/1907. APMP/FMP, Série Correspondência; CARTA, em alemão, com tradução anexa, de H. Sander a Hermann von Ihering, Köln, 17/09/1907. APMP/FMP, Série Correspondência.

${ }_{317}$ CARTA, em alemão, com tradução anexa, de H. Sander a Hermann von Ihering, Köln, 16/03/1912. APMP/FMP, Série Correspondência.
} 
"Produção fiel à realidade de grupos de animais para museus" (trad. nossa). ${ }^{318}$ Sander era um taxidermista que se dedicava particularmente a preparações artísticas, isto é, à preparação de animais (e grupos de animais) em poses dinâmicas (reproduzindo os comportamentos que apresentariam na natureza) para exposições.

Segundo Köstering, os estúdios de Sander (em Colônia) e de Umlauff (em Hamburgo) podem ser considerados as duas principais oficinas de preparação existentes fora de museus na Alemanha imperial. O empreendimento de Sander tinha por especialidade a montagem de grupos de animais em cenas de luta altamente dramáticas. $\mathrm{O}$ preparador realizou montagens para diversos museus alemães, entre eles o Altonaer Museum e o Kölner Naturkundemuseum - o último, segundo a autora, acabava por se constituir em verdadeira vitrine da empresa de taxidermia, já que continha, em suas exposições, diversos grupos de mamíferos africanos preparados por Sander. ${ }^{319}$

Ihering parecia interessado, portanto, na elaboração de exposições mais atrativas, de modo que cogitou adquirir espécimes montados na Europa por profissional especializado, reconhecido por trabalhos de impacto visual. Além de ter dado início a pequenas iniciativas visando rearranjar a ordenação dos espécimes expostos.

Essas alterações nos parâmetros expositivos estavam atreladas tanto a mudanças nos paradigmas das ciências naturais quanto a um movimento dos museus em direção ao público. No caso do Museu Paulista, relacionavam-se também com a tentativa do museu de se firmar como um lugar atrativo para os visitantes. Para isso, ele tinha que disputar a atenção do público com outros espaços. Ficando apenas no universo das exposições de História Natural, inaugurou-se em 1905, no centro de São Paulo, uma exposição zoológica particular (provavelmente de caráter temporário). De acordo com o que foi veiculado n'O

318 "Dermoplastische Modellierung grosser und grösster Tiere (Menschenaffen und Dickhäuter)"; "Herstellung lebenswahrer Tiergruppen für Museen". CARTA, em alemão, com tradução anexa, de H. Sander a Hermann von Ihering, Köln, 16/03/1912. APMP/FMP, Série Correspondência. A parte impressa do papel de carta não apresenta tradução.

${ }^{319}$ KöSTERING, Susanne, op. cit., 2003, pp. 178-179. 
Estado de S. Paulo, tal exposição já apresentava algumas dessas características inovadoras. Podemos cogitar que ela pudesse ser, portanto, mais atrativa para os visitantes do que o Museu Paulista. Segundo o jornal:

Realizou-se, ontem, a inauguração do Museu zoológico, dos srs. José Pilar \& Sá, à rua Florêncio de Abreu, 20 A.

É pena que o local, um pouco acanhado, não deixe sobressair toda a variada e numerosa coleção de animais, exposta com muito gosto e arte. Os animais, muito bem empalhados, conservam atitudes naturais, dando muitos deles a ilusão de vida.

Entre os animais expostos, figuram: lobos, quatis, cachorros do mato, guaxinim acuando um bando de quatis, jacarés, lontras, pacas, capivara, veados, corças e filhotes, gatos do mato, catetos, tamanduás, tatus, diversas espécies de cobras, suçuarana matando um índio, macacos, grande número de aves terrestres e aquáticas, peixes de rio, etc.

Em suma, o museu zoológico é altamente interessante e curioso e merece ser visitado. ${ }^{320}$

Barbuy, examinando práticas expositivas correntes em São Paulo no século XIX, trata de algumas exposições itinerantes vindas da Europa, as quais conjugam apelo popular e um caráter científico (como uma exposição de figuras de cera ocorrida na cidade em 1875). ${ }^{321}$ A exposição zoológica particular acima referida, como parte dessa larga cultura de exposições, deveria funcionar como mais um fator motivador para o Museu Paulista tentar renovar suas exposições. ${ }^{322}$

\footnotetext{
${ }^{320}$ Museu Zoológico. O Estado de S. Paulo, 24/12/1905, p. 3.

${ }^{321}$ BARBUY, Heloisa, op. cit, pp. 260-263.

${ }^{322}$ Nyhart indica que, em diversas cidades alemãs do século XIX, existiam várias alternativas de muito mais apelo para se ver e aprender sobre a natureza: jardins públicos, parques, trilhas na mata, jardins zoológicos e botânicos, aquários, museus de cera, panoramas, shows itinerantes, grupos que realizavam performances etnográficas, circos e menageries itinerantes. Segundo a autora, a separação entre coleções de estudo e de exposição, e a sofisticação dos discursos expositivos que a ela se seguiu, pode ser vista como uma resposta dos museus a essa constelação de opções para experimentar a natureza. Ver NYHART, Lynn K, op. cit., 2009, pp. 218-223.
} 


\subsection{Usos e visões das exposições}

Como vimos, ao longo da gestão Ihering, o Museu Paulista procurou aprimorar seus discursos expositivos. O que abarcou desde a reorganização da antiga Coleção Sertório num arranjo disciplinar e taxonômico, até a incorporação de novas linhas expositivas (Zoogeografia e Biologia animal), as quais envolviam a constituição de taxidermias melhores e o arranjo de animais de modo a evidenciar seus comportamentos na natureza.

Ainda não nos detivemos, todavia, sobre o modo como os visitantes percebiam as exposições do Museu. Aqui, tentaremos examinar como o público encarava as exposições da instituição e os novos discursos expositivos que ela procurava incorporar.

Não são muitas as fontes que nos permitem saber como eram percebidas pelos visitantes as exposições do Museu Paulista. Consistem em breves passagens em obras de cronistas e viajantes que, estando na cidade de São Paulo, visitaram o Museu. Tais relatos destacam ora a profusão de espécimes, ora alguns exemplares considerados interessantes por conta de alguma singularidade.

Por exemplo, o político francês Georges Clemenceau (1841-1929), que visitou a América do Sul em 1910, mostra-se impressionado, em seu relato de viagem, com algumas borboletas muito grandes e alguns beija-flores minúsculos expostos no Museu: "Très belles collections de zoologie, de botanique, de paléontologie. On me fait admirer de papillons qui ont près de 30 centimètres d'envergure et des oiseauxmouches sensiblement plus petits qu'un hanneton." ${ }^{323}$

Por sua vez, Marie Robinson Wright (1866-1914), jornalista americana que esteve no Brasil (provavelmente em 1899), ${ }^{324}$ chama atenção, em sua obra sobre o Brasil, tanto para uma peça singular (um louva-deus), quanto para a infinidade de borboletas expostas e para a sistematicidade da classificação:

${ }^{323}$ Clemenceau, Georges. Notes de voyage dans l'Amerique du Sud: Argentine, Uruguay, Brésil. Paris: Hachette, 1911, p. 245.

${ }^{324}$ CANDEIAS, Nelly Martins Ferreira. Marie Robinson Wright: página da internet. Disponível em: http://www.jbcultura.com.br/index.html. Acesso em: 10 de dez. de 2013. 
The Louvadeus [Praise God] grasshopper, that regularly makes its way to the top of a bush or tree and puts up its feelers in an attitude of prayer, is another curiosity of which many specimens are preserved in this museum; and of butterflies the collection is apparently endless in variety. Curiosities of the mineral as well as of the animal kingdom have been culled from every available source, the classification being so systematically arranged as greatly to facilitate inspection. ${ }^{325}$

O artista inglês Archibald Stevenson Forrest (1869-1963), que também viajou pela América do Sul no início do século XX, destaca, de modo semelhante, tanto as séries de objetos apresentados conjuntamente, quanto a existência de curiosidades ou aberrações:

\begin{abstract}
Amongst the many curious and instructive objects gathered together are pottery from all parts of the continent, including Colombian, Peruvian, and Mexican; stuffed fish, weird in shape and marvelous in variety, taken from the rivers; lizards, chameleons, turtles, alligators, and snakes. Here, too, are specimens of the feathers and ornaments worn by the savage Indian tribes of the State of São Paulo, head-dresses of yellow feathers, necklaces of human teeth, collars of green parrot feathers and bettles' wings, and of beadwork mixed with feathers.
\end{abstract}

(...)

Amongst the stuffed animals are such curiosities or freaks as a calf with only two legs, and another with two heads. ${ }^{326}$

O jurista Jorge Americano (1891-1969), em um de seus seu livros de reminiscências, também assinala, a um só tempo, algumas peças singulares e a profusão de insetos, pássaros, cobras e macacos:

O que me interessava, porém, era a parte zoológica, esqueletos e animais empalhados. Quadros de moscas, besouros e borboletas, espetados em alfinetes. Pássaros de todos os tamanhos. O 'joão-de-barro' fazendo a casa, e o 'pica-pau' abrindo o buraco na madeira. A 'hiena devoradora de cadáveres' era uma decepção. Não passava de um gatinho. Micos, saguis, macacos. Jaguatirica, onça pintada. E cobras de todas as cores e

\footnotetext{
${ }^{325}$ WRIGHT, Marie Robinson. The new Brazil: its resources and attractions: historical, descriptive, and industrial. 2nd ed. Philadelphia: George Barrie \& Sons, ca.1907, p. 208. (1. ed. 1901).

${ }^{326}$ FORREST, Archibald S. A tour through South America. London: Stanley Paul \& co, [1913?], p. 308.
} 
tamanhos, até a jiboia, enrolada num bezerro para esmagar-Ihe os ossos e comê-Io. ${ }^{327}$

O autor menciona ainda as peças no peristilo do Museu: "No saguão estava um esqueleto de baleia e uma águia zarolha engaiolada., ${ }^{328}$

Esse destaque ora para a profusão de objetos, ora para algumas peças chamativas, diz respeito a dois modos distintos de apreender os objetos expostos no Museu. O primeiro se refere à exploração dos conjuntos organizados taxonomicamente, ao visitante entorpecido pela infinidade de formas e cores da natureza neotropical, ao olhar comparador que busca os pontos de contato entre objetos aparentados. O segundo diz respeito à fruição de peças singulares, que chamam atenção por conta de algum aspecto significativo ou inusitado, como um louva-deus ou borboletas enormes. Esse interesse por peças singulares pode ser lido como uma forma de apropriação do Museu mais próxima daquela realizada pelo público leigo. São formas de vivenciar o Museu que deixam um pouco de lado a organização taxonômica, e as demais soluções expositivas, para experimentá-lo por meio de outras chaves: aquelas ligadas às formas de relação que o leigo trava com os animais - às vezes utilitarista, às vezes fruitiva.

O próprio Guia pelas collecções do Museu Paulista induz, e nos revela, outras percepções possíveis. Por exemplo, quando nos diz que determinados animais constituem caça apreciada: caso da anta, "que naturalmente constitui caça apreciadíssima" ${ }^{329}$ e do uru, ave "das melhores caças quanto ao sabor da carne." 330 Ou quando indica que determinados animais podem ser perigosos para o homem, caso do queixada (porco do mato), que "torna-se perigoso quando atacado, pois rasga profundas feridas com as suas grandes dentuças". ${ }^{331}$

No que se refere às aves, o Guia também nos dá indicações de interessantes formas como as peças do Museu poderiam ser lidas ou apropriadas pelos visitantes. Primeiramente, um interesse pela beleza e colorido das plumagens de determinadas aves, como as "grandes 'Araras' (Ara) de cauda longa e colorido variegado", ou os

\footnotetext{
${ }^{327}$ AmERICANO, Jorge. São Paulo naquele tempo (1895-1915). 2ª. ed. São Paulo: Carrenho/Narrativa Um/Carbono 14, 2004 (1 ${ }^{\text {a }}$ ed. 1957), p. 302.

328 Ibidem, p. 301.

329 IHERING, Rodolpho von, Guia cit., 1907, pp. 108-109.

330 Ibidem, p. 88.

${ }^{331}$ Ibidem, p. 108-109.
} 
beija-flores, essas "sedutoras criaturas" sobre as quais nos diz o Guia: "Aliam-se neles a graciosidade da forma ao esplendor do colorido da plumagem e é sobretudo a resplandecência dos furta-cores metálicos que sempre de novo nos fascina." ${ }^{332}$

O canto das aves também é destacado pelo Guia. Descrevendo o conteúdo de uma das vitrines da primeira sala de aves, informa: "Estão aqui reunidas diversas famílias que todas contam em seu número exímios cantores." E complementa dizendo que “(...) 'Patativas', 'Bicudos', ‘Papa-capins', 'Coleirinhas' e o 'Cardeal' dãose bem em gaiolas e são todos muito apreciados pelo seu canto melodioso." 333

Mas algumas aves também são percebidas como seres danosos a determinadas atividades humanas, como a agricultura: "Nas plantações, porém, todas estas aves nunca são bem vistas [referindo-se aos Psittaciformes], pois, especialmente no milharal, causam grandes danos." ${ }^{334}$

Enfim, as peças expostas podiam ser objeto de interesse por diferentes motivos.

Além da profusão de espécimes ordenados sistematicamente e das formas leigas de apropriação das peças do Museu, as exposições de comportamento animal - como “o 'joão-de-barro' fazendo a casa, e o 'pica-pau' abrindo o buraco na madeira", destacados por Jorge Americano - deviam estar na mira do público. Alguns relatos sugerem que, entre os visitantes conhecedores de museus de História Natural estrangeiros, era grande a expectativa por exposições desse tipo. A ponto de enxergarem tais cenas onde elas não existiam - como fez Gina Lombroso - ou de se queixarem da ausência de animais em atitudes naturais, como num texto publicado n'O Estado de S. Paulo em 1912.

A italiana Gina Lombroso (1872-1944), filha do antropólogo e criminologista Cesare Lombroso, em sua viagem pela América Latina no ano de 1907, parece ter visto um museu pouco parecido com o que nos sugerem as demais fontes:

La fauna e la flora e l'etnologia brasiliana cosi variate per forme e colori, e la cura com cui il museo è stato ordinato, rendon l'lpiranga uno dei più interessanti musei del mondo. Gli animali, le piante, i ricordi degli Indiani non

\footnotetext{
332 Ibidem, p. 81 e p. 83.

333 Ibidem, p. 85.

${ }^{334}$ Ibidem, p. 81.
} 
sono accatastati nelle vetrine, ma disposti al vivo su uno sfondo dipinto a panorama; voi vedete sulle azzurre acque del Rio dele Amazzoni nuotare dei pesci così vivamente colorati come le farfalle, e volare dele farfalle che sembrano dei fiori, e correre degli ucceli che hanno le forme più strane ed inattese, e li vedete coi loro nidi, colle loro dimore, sui loro alberi coi loro compagni di vita, nei loro atteggiamenti naturali. I serpenti /p. 34/ dormono, strangolano, spiccano salti che sembran voli, facendo brillare le variopinte scaglie che luccicano com riflessi metallici acanto alle case delle formiche, di cui potete penetrare nei più intimi meandri. ${ }^{335}$

Embora, como vimos, o Museu estivesse envidando esforços no sentido de incorporar novas soluções expositivas - de modo a apresentar animais em seus comportamentos considerados naturais -, nenhuma outra fonte indica que as vitrines tivessem sido abolidas em favor de dioramas.

Na margem oposta está o artigo publicado n'O Estado de S. Paulo em 1912. $O$ autor, que assina apenas P. P., traça o perfil de uma instituição anacrônica, um "depósito de curiosidades", cujas "(...) salas tinham um aspecto fúnebre, sombrio, com as janelas semicerradas, dificultando um exame." ${ }^{336}$ Segundo ele, a organização pouco arrojada das coleções expostas as tornava inaptas a "mostrar ao vivo a natureza":

Para os poderes públicos e para a população em geral, nosso museu tem sido considerado mais como um depósito de curiosidades do que como local de estudos científicos. No fundo, ele permanece a mesma antiga coleção organizada pelo coronel Sertório, sem critério e método. Ainda não é um conjunto de espécimes capaz de mostrar ao vivo a natureza e a história da terra paulista para ilustração de nacionais e estrangeiros. ${ }^{337}$

O autor defende que o Museu Paulista tenha um papel educativo mais destacado e recomenda que, para atingir tal objetivo, a instituição reforme suas exposições, de modo que os espécimes sejam exibidos reproduzindo seu comportamento na natureza. Segundo o artigo:

$\mathrm{Na}$ Europa os museus não são unicamente locais destinados às observações e estudos de homens de ciência. São igualmente destinados à

${ }^{335}$ FerRero, Gina Lombroso. Nell'America meridionale (Brasile, Uruguay, Argentina). Milano: Fratelli Treves, 1908, pp. 33-34.

${ }^{336}$ P. P. Notas Pedagógicas. O Estado de S. Paulo, 27/06/1912, p. 3.

${ }^{337}$ Ibidem, p. 3 (grifo nosso). 
instrução do povo e da infância, aos quais procuram interessar com exposições, conferências, etc.

\section{(...)}

Seria para desejar que, para idêntico efeito, nos mostruários do museu os espécimes se harmonizassem mais com as cenas da natureza viva, como é de regra nos congêneres europeus e norte-americanos. Coloquem-se os animais em suas posições habituais, este caçando, aquele subindo a árvore, outro comendo seu alimento predileto, as aves junto a seus ninhos e ovos. É como se tornariam as coleções mais instrutivas para os visitantes que não fossem versados na matéria. ${ }^{338}$

A resposta a tais críticas demorou pouco mais de dois meses para aparecer nas páginas do mesmo jornal. Às vésperas das comemorações pela passagem da data de 7 de setembro, Ihering publica artigo tratando dos melhoramentos que vinham sendo efetuados no Museu: "As coleções expostas ao público vão se transformando, mas continuamente, de modo que as preparações antigas do Museu Sertório são aos poucos substituídas por novas, mais aperfeiçoadas."339

Afirma então que, no ano anterior, diversos animais taxidermizados - 78 aves e 6 mamíferos, "além de outros de menos importância" - foram incluídos nas exposições do Museu, "em substituição de outros, mal empalhados". Cita como exemplo um lobo, doado pelo Jardim Público, que havia sido taxidermizado pelo preparador do Museu, João Lima, "segundo o moderno sistema taxidérmico, denominado 'método plástico'”. 340

Prossegue falando de reformas que vinham sendo feitas nas legendas dos espécimes e, em seguida, lembra mais uma vez que o Museu não se restringia às coleções expostas ao público, contando com vastas coleções de estudo. Afirma ainda que era preciso ter certos cuidados ao se comparar o Museu Paulista com instituições congêneres dos Estados Unidos e da Europa:

Com os seus parcos recursos e o seu diminuto pessoal científico, o Museu do Estado não se pode comparar com os grandes estabelecimentos congêneres do Velho Mundo e da América do Norte. Como, porém, tem restringido o seu programa à fauna da América Meridional e particularmente

\footnotetext{
338 Ibidem, p. 3.

${ }^{339}$ IHERING, Hermann von. Museu do Estado. O Estado de S. Paulo, 06/09/1912, p. 6.

340 Ibidem, p. 6. Sobre o método plástico, ver o item 3.2 desta dissertação.
} 
do Brasil, o Museu Paulista conseguiu assim lugar honroso nos círculos científicos internacionais. ${ }^{341}$

A natureza oferecida aos olhos do visitante o Museu Paulista não possuía um significado único. As exposições do Museu, ao se filiarem às diferentes áreas de pesquisa da Zoologia do período, possibilitavam ao visitante diferentes formas de experimentar a natureza. Por meio do recorte geográfico (a natureza sul-americana com ênfase em São Paulo e no Brasil), compunha-se um quadro panorâmico da natureza do estado e por vezes do país. O arranjo taxonômico, por sua vez, direcionava a apreciação das coleções para o entendimento da natureza como um sistema logicamente ordenado, em que cada peça ocupa seu lugar num sistema organizado por critérios morfológicos.

Por sua vez, no âmbito desse recorte e desse arranjo, existiam outras soluções expositivas que veiculavam concepções outras sobre o mundo animal. Um grupo biológico, tal qual o da coruja do campo citado acima, indicava um entendimento dos animais como seres que possuem determinados comportamentos e modos de viver. Não são, portanto, aqui, apenas peças de um quebra-cabeças taxonômico. As exibições de mimetismo de insetos, de modo semelhante, instruem sobre alguns mecanismos de funcionamento do mundo animal - que, além disso, possuem consideráveis consequências teóricas, uma vez que o fenômeno do mimetismo pode ser apreendido sob a chave de ideias darwinistas de sobrevivência do mais apto e seleção natural. ${ }^{342}$

$\mathrm{Na}$ falta de painéis com textos explicativos nas salas de exposição, o Guia podia funcionar como um mecanismo complementar ao material exposto, abrindo possibilidades de leituras outras que aquelas explicitadas pelo próprio modo de organização das peças expostas no Museu.

As exposições do Museu Paulista, portanto, não apresentavam uma visão única da natureza. Ao contrário, sugeriam uma pluralidade de caminhos de leitura, pela própria configuração material das exposições, o que era amplificado pelas

\footnotetext{
341 Ibidem, p. 6.

${ }^{342}$ Ver KösTERING, Susanne, op. cit., 2003, p. 110.
} 
possibilidades interpretativas sugeridas pelo Guia, sem falar nas interpretações feitas pelo visitante leigo a partir de seus próprios referenciais.

O que gostaríamos de ressaltar é que o objeto de História Natural, o espécime científico montado para ser exposto, é o elemento fundamental na elaboração de todas essas visões da natureza. O espécime materialmente constituído e expograficamente preparado é fundamental para que ocorra essa aproximação com a natureza, é fundamental para que sejam verossímeis esses vários discursos sobre a natureza. Daí o esforço empreendido, durante a gestão Ihering, para progressivamente substituir as peças provenientes da Coleção Sertório por outras preparadas de modo a melhor cumprir a função de mediadoras num processo didático de imaginação sobre a natureza. 


\section{Considerações finais}

Partindo do pressuposto de que os objetos são a principal razão de ser dos museus, em especial no século XIX e início do XX, procuramos, neste trabalho, investigar alguns aspectos envolvidos na curadoria de espécimes científicos no Museu Paulista gerido por Hermann von Ihering.

O exame de processos de aquisição e uso de espécimes no âmbito do Museu permitiu-nos, além de aprofundar o conhecimento acerca da instituição, observar aspectos do funcionamento da História Natural, entre os séculos XIX e XX, que extrapolam o Museu Paulista.

O estabelecimento, em solo brasileiro, de caçadores que se encarregavam de obter e preparar espécimes animais para serem remetidos a museus e revendedores, situados no Brasil e na Europa, era condição indispensável para que os museus de História Natural do Brasil e do mundo pudessem obter os materiais necessários às suas pesquisas científicas e exposições públicas. Ao mesmo tempo, como vimos, a existência dessas redes que conectavam caçadores, revendedores, colecionadores privados e museus era fundamental para que os primeiros pudessem subsistir nesse ramo de negócios.

Desse modo, ao incentivar a conexão entre coletores residentes no Brasil e casas comerciais sediadas na Europa, o Museu Paulista de Ihering não só fomentava a profissionalização dos primeiros, como garantia a existência de um mercado dinâmico do qual o próprio Museu (entre outras instituições congêneres) se aproveitava para complementar suas coleções.

Ao identificar alguns dos atores envolvidos nessas redes, bem como aspectos de seu funcionamento, foi possível contribuir - assim esperamos - não só com o entendimento das estratégias de aquisição de espécimes por parte do Museu Paulista, mas também com a compreensão de alguns mecanismos importantes para o funcionamento das ciências naturais entre os séculos XIX e XX.

A análise do papel dos espécimes na produção de conhecimento, por sua vez, permitiu-nos não apenas explicitar os procedimentos envolvidos nessas 
atividades científicas, mas também compreender melhor como as agendas de pesquisa e paradigmas científicos direcionavam as atividades de coleta e preparação no período em questão (formação de séries; obtenção de matérias de diferentes pontos do território; incorporação de crâneos nas coleções de mamíferos, etc.).

Já o exame das exposições do Museu permitiu-nos observar como circulavam entre os diferentes museus de História Natural não apenas espécimes e informações científicas, mas também ideias e técnicas expográficas. Ao procurar, em conexão com o que vinha se fazendo em museus de História Natural estrangeiros, sofisticar seus discursos expositivos, o Museu precisou adotar novas técnicas taxidérmicas e novas formas de apresentação dos espécimes nas exposições. Para a incorporação do "método plástico" (e, consequentemente, de animais em poses naturais ou vivas) e das novas formas de ordenação dos preparados (por exemplo, zoogeograficamente ou em grupos biológicos) foram fundamentais as viagens do diretor e do zelador do Museu à Europa.

Enfim, esperamos, com esse exame de aspectos da curadoria de algumas das coleções de História Natural do Museu Paulista, ter contribuído para o entendimento das relações intrínsecas entre ciências naturais e cultura material existentes entre os séculos XIX e XX. 


\section{Fontes e bibliografia}

\section{Fontes}

Documentos de arquivos

Acervo da Seção de Ornitologia do Museu de Zoologia da USP:

MuSEu Paulista: Catálogo Accessional: Aves. Tomos 1 e 2.

Serviço de Documentação Textual e Iconografia do Museu Paulista da USP:

Coleção Alexandre Hummel;

Arquivo Permanente do Museu Paulista/Fundo Museu Paulista:

Grupo Direção e Administração. Subgrupo Comunicação e Intercâmbio. Série Correspondência enviada e recebida, 1894-1916;

Grupo Direção e Administração. Subgrupo Comunicação e Intercâmbio. Série Matérias jornalísticas sobre o Museu Paulista, 1893-1931;

Grupo Direção e Administração. Subgrupo Finanças. Série Prestação de contas, 1894-1916;

Grupo Direção e Administração. Subgrupo Fixação de Políticas e Planejamento. Dossiê Comissão de Sindicância sobre a gestão de Hermann von Ihering, 1916-1920;

Grupo Direção e Administração. Subgrupo Patrimônio e Almoxarifado. Série Relações de aquisições, 1894-1916;

Grupo Direção e Administração. Subgrupo Pessoal e Admissão. Série Termos de compromisso de funcionários, 1894-1904. 
SÃo Paulo. Decreto n. 249, de 26 de julho de 1894. Aprova o Regulamento do Museu do Estado, para execução da Lei n. 200, de 29 de Agosto de 1893. Disponível em:

http://www.al.sp.gov.br/repositorio/legislacao/decreto/1894/decreto-24926.07.1894.html. Acesso em: 10 de set. de 2012.

Periódicos

Chacaras e Quintaes, 1910-1915;

Correio Paulistano, 1894-1916;

O Entomologista Brasileiro, 1908-1910;

O Estado de S. Paulo, 1894-1916;

Revista do Museu Paulista, 1-10, 1895-1918.

Fontes impressas

Americano, Jorge. São Paulo naquele tempo (1895-1915). 2ª ed. São Paulo: Carrenho/Narrativa Um/Carbono 14, 2004 (1‥ ed. 1957).

Brölemann, H. Os Myriapodos do Brazil. São Paulo: Cardozo, Filho e C., 1909 (Catalogos da Fauna Brazileira, 2).

Clemenceau, Georges. Notes de voyage dans l'Amerique du Sud: Argentine, Uruguay, Brésil. Paris: Hachette, 1911.

DuCKE, Adolpho. As Chrysididas do Brazil. São Paulo: Typographia do Diario Official, 1913 (Catalogos da Fauna Brazileira, 4).

FerRero, Gina Lombroso. Nell'America meridionale (Brasile, Uruguay, Argentina). Milano: Fratelli Treves, 1908.

FORREST, Archibald S. A tour through South America. London: Stanley Paul \& Co., [1913?]. 
Hempel, Adolph. As coccidas do Brazil. São Paulo: Typographia do Diario Official, 1912 (Catalogos da Fauna Brazileira, 3).

IHERING, Hermann von; IHERING, Rodolpho von. As aves do Brasil. São Paulo: Typographia do Diario Official, 1907 (Catalogos da Fauna Brazileira, 1).

IHERING, Rodolpho von. Guia pelas collecções do Museu Paulista. São Paulo: Cardozo, Filho \& Cia, 1907.

PInTO, Alfredo Moreira. A cidade de São Paulo em 1900: impressões de viagem. 2 ${ }^{a}$. ed. São Paulo: Governo do Estado de São Paulo, 1979 (1ª . ed. 1900).

TAUnAy, Afonso de E. Comemoração do cinquentenário da solene instalação do Museu Paulista. Separata de Administração Pública, 3, 4, dez. 1945. São Paulo: Governo do Estado de São Paulo, Departamento do Serviço Público, Serviço de Documentação, 1946.

WrIGHT, Marie Robinson. The new Brazil: its resources and attractions: historical, descriptive, and industrial. 2nd ed. Philadelphia: George Barrie \& Sons, ca.1907 (1. ed. 1901).

\section{Materiais digitais}

Arquivo Público do Estado de São Paulo. Livros de Registro da Hospedaria de Imigrantes: banco de dados. Disponível em: http://www.arquivoestado.sp.gov.br/livros estrangeiros.php. Acesso em: agosto de 2013.

CANDEIAS, Nelly Martins Ferreira. Marie Robinson Wright: página da internet. Disponível em: http://www.jbcultura.com.br/index.html. Acesso em: 10 de dez. de 2013.

CASA de Oswaldo Cruz. Dicionário Histórico-Biográfico das Ciências da Saúde no Brasil (1832-1930): banco de dados. Disponível em: 
http://www.dichistoriasaude.coc.fiocruz.br/iah/pt/index.php. Acesso em: agosto de 2013.

DeYRolle. L'historique de la maison: página da internet. Disponível em: http://www.deyrolle.com/magazine/spip.php?article149. Acesso em: 15 de março de 2012.

ITAÚ Cultural. Enciclopédia de artes visuais: banco de dados. Disponível em: http://www.itaucultural.org.br/aplicexternas/enciclopedia ic/. Acesso em: 13 de dezembro de 2013.

LILLY Library Manuscript Collections. Moenkhaus Mss: página da internet. Disponível em: http://www.indiana.edu/ liblilly/lilly/mss/index.php?p=moenkhau. Acesso em: 9 de out. de 2013.

OBERÖSTERREICHISCHES Landesmuseen. Zobodat - Zoologisch-Botanische Datenbank: banco de dados. Disponível em: http://www.zobodat.at. Acesso em: março de 2012.

Senckenberg Deutsches Entomologisches Institut. Biografien der Entomologen der Welt: banco de dados. Disponível em: http://www.sdei.de/biographies/. Acesso em: junho de 2012.

The Mineralogical Record: banco de dados. Disponível em: http://www.minrec.org/labelarchive.asp. Acesso em: junho de 2012.

\section{Referências bibliográficas}

AlbertI, Samuel J. M. M. (org.). The Afterlives of Animals: A Museum Menagerie. Charlottesville and London: University of Virginia Press, 2011.

Nature and Culture: Objects, Disciplines and the Manchester Museum. Manchester: Manchester University Press, 2009.

. Objects and the museum. Isis, 96, 4, 2005, pp. 559-571. 
Alves, Ana Maria de Alencar. O lpiranga apropriado: ciência, política e poder: o Museu Paulista, 1893-1922. São Paulo: Humanitas/FFLCH-USP, 2001. Originalmente Dissertação (Mestrado) defendida na Faculdade de Filosofia, Letras e Ciências Humanas da Universidade de São Paulo em 1998.

- Redutos da ciência na "era dos museus": Inglaterra, França, Estados Unidos e Brasil. São Paulo, 2004. Tese (Doutorado) - Faculdade de Filosofia, Letras e Ciências Humanas, Universidade de São Paulo.

ANÔNIMO. Andreas Bang-Haas. Zeitschrift des Österr. Entomologen Vereines, 10, 3, mar. 1925, pp. 21-22. Disponível em: http://www.landesmuseum.at/pdf frei remote/ZOEV 10 0021-0022.pdf. Acesso em: março de 2012.

ANÔNIMO. G. Baer. Bulletin de la Société Entomologique de France, 1918, pp. 53-54.

ANÔNImo. Ricardo Krone. Revista do Museu Paulista, 10, 1918b, pp. 929-938.

Aranha FILHo, Jayme Moraes. Guia da impermanência das exposições: uma investigação sobre transformações do Museu Nacional do Rio nos anos 1940. Rio de Janeiro, 2011. Tese (Doutorado) - Instituto de Filosofia e Ciências Sociais, Universidade Federal do Rio de Janeiro.

BaLdus, Herbert. Curt Nimuendajú. Boletim Bibliográfico, 2, 7, pp. 91-99. Disponível em: http://biblio.etnolinguistica.org/baldus-1945-nimuendaju. Acesso em: setembro de 2011.

Barbuy, Heloisa. "O campus do Ipiranga." In: LanNA, Ana Lúcia Duarte. Cidades universitárias: patrimônio urbanístico e arquitetônico da USP. São Paulo: Edusp/Imprensa Oficial do Estado, 2005, pp. 35-41.

A cidade-exposição: comércio e cosmopolitismo em São Paulo, 18601914. São Paulo: Edusp, 2006. Originalmente Tese (Doutorado) defendida na Faculdade de Arquitetura e Urbanismo da Universidade de São Paulo em 2001.

. "Cultura de exposições em São Paulo, no século XIX". In: LOPES, Maria Margaret; Heizer, Alda (orgs.). Colecionismos, práticas de campo e representações. Campina Grande: Eduepb, 2011, pp. 257-268. 
A Exposição Universal de 1889 em Paris: visão e representação na sociedade industrial. São Paulo: Loyola/História Social USP, 1999. Originalmente Dissertação (Mestrado) defendida na Faculdade de Filosofia, Letras e Ciências Humanas da Universidade de São Paulo em 1995.

. "O Museu Paulista e a Pinacoteca do Estado". In: Araujo, Marcelo Mattos; Camargos, Marcia (orgs.). Pinacoteca: a história da Pinacoteca do Estado de São Paulo. São Paulo: Artemeios, 2007, pp. 137-145.

. "Museus, exposições e cidades: cultura visual no século XIX". In: OliveIRA, Cecilia Helena de Salles; BARBuY, Heloisa (orgs.). Imagem e produção de conhecimento. São Paulo: Museu Paulista/USP, 2002, pp. 66-78.

BARROW, Mark V. The Specimen Dealer: Entrepreneurial Natural History in America's Gilded Age. Journal of the History of Biology, 33, 3, 2000, pp. 493-534.

Bennett, Tony. Pasts Beyond Memory: Evolution, Museums, Colonialism. London: Routledge, 2004.

Brefe, Ana Cláudia Fonseca. O Museu Paulista: Affonso de Taunay e a memória nacional, 1917-1945. São Paulo: Unesp/Museu Paulista, 2005. Originalmente Tese (Doutorado) defendida no Instituto de Filosofia e Ciências Humanas da Universidade Estadual de Campinas em 1999.

Camargo, Hélio F. de Almeida. Helmuth Pinder, o primeiro coletor e taxidermista de aves do Museu Paulista. Ararajuba, 6, 1, 1998, pp. 54-57.

Carvalho, Paula Carolina de Andrade. O Museu Sertório: uma coleção particular em São Paulo no século XIX (primeiro acervo do Museu Paulista). São Paulo, 2013. Relatório de Iniciação Científica apresentado à Fapesp - Museu Paulista, Universidade de São Paulo.

DIAS, Nélia. Le Musée d'Ethnographie du Trocadéro (1878-1908): Anthropologie et Muséologie en France. Paris: CNRS, 1991.

DUARTE, Regina Horta. Pássaros e cientistas no Brasil: Em busca de proteção, 18941938. Latin American Research Review, 41, 1, 2006, pp. 3-26. 
ELIAS, Maria José. Museu Paulista: memória e história. São Paulo, 1996. Tese (Doutorado) - Faculdade de Filosofia, Letras e Ciências Humanas, Universidade de São Paulo.

FARRO, Máximo. "Colecciones de cráneos, fotografías y manuscritos en el desarollo de la antropología física y de la etnografía lingüística em la Argentina a fines del siglo XIX". In: LOPES, Maria Margaret; HeIZER, Alda (orgs.). Colecionismos, práticas de campo e representações. Campina Grande: Eduepb, 2011, pp. 93104.

FIgUeIRÔA, Silvia Fernanda de Mendonça. As ciências geológicas no Brasil: uma história social e institucional, 1875-1934. São Paulo: Hucitec, 1997.

Modernos Bandeirantes: a Comissão Geográfica e Geológica de São Paulo e a exploração científica do território paulista. São Paulo, 1987. Dissertação (Mestrado) - Faculdade de Filosofia, Letras e Ciências Humanas, Universidade de São Paulo.

FORGAN, Sophie. Building the museum - knowledge, conflict and the power of place. Isis, 96, 4, 2005, pp. 572-585.

Gualtieri, Regina Cândida Ellero. Evolucionismo no Brasil: ciência e educação nos museus, 1870-1915. São Paulo: Livraria da Física, 2008. Originalmente Tese (Doutorado) defendida na Faculdade de Filosofia, Letras e Ciências Humanas da Universidade de São Paulo em 2001.

GUTSCHE, Alexander et al. Wilhelm Ehrhardt and an evaluation of his amphibians and reptiles held in the Herpetological Collection of the Museum für Naturkunde, Berlin. Mitteilungen aus dem Museum für Naturkunde in Berlin - Zoologische Reihe, 83, 1, 2007, pp. 80-93.

Hancock, E. G.; Howell, A.; Torrens, H. S. Geological collections and collectors of note 11. Bolton Museum. Newsletter of the Geological Curators Group, 7, 1976, pp. 323-35. Disponível em: http://www.geocurator.org/arch/Curator/Vol1No7.pdf. Acesso em: março de 2012.

Hellmayr, Carl E. A contribution to the ornithology of northeastern Brazil. Chicago: Field Museum of Natural History, 1929 (Zoological Series, 12, 18). 
HoOPER-GreenHILL, Eilean. Museums and the Interpretation of Visual Culture. London: Routledge, 2000.

IDE, S. et al. Coleção Entomológica "Adolph Hempel", Instituto Biológico, São Paulo: História, importância e função. Páginas do Instituto Biológico, 1, 1, jan.-jun. 2005. Disponível em http://www.biologico.sp.gov.br/docs/pag/v1 1/ide.htm. Acesso em: 13 ago. 2013.

KNAPPETT, Carl. Thinking through material culture: an interdisciplinary perspective. Philadelphia: University of Pennsylvania Press, 2005

KOHLER, Robert E. All Creatures: Naturalists, Collectors, and Biodiversity, 1850-1950. Princeton: Princeton University Press, 2006.

KOHLSTEDT, Sally Gregory. "Thoughts in Things" - Modernity, History, and North American Museums. Isis, 96, 4, 2005, pp. 586-601.

KOHLSTEDT, Sally Gregory; BRINKMAN, Paul. Framing Nature: the formative years of natural history museum development in the United States. Proceedings of the California Academy of Sciences, 55, supplement I, out. 2004, pp. 7-33.

KöSTERING, Susanne. Natur zum Anschauen: das Naturkundemuseum des deutschen Kaiserreichs 1871-1914. Köln: Böhlau, 2003.

LANGE, Britta. Echt. Unecht. Lebensecht. Menschenbilder im Umlauf. Berlim: Kadmos, 2006.

Larsen, Anne. "Equipment for the field". In: Jardine, N.; Secord, J. A.; Spary, E. C. (eds.). Cultures of natural history. Cambridge: Cambridge University Press, 1996, pp. 358-377.

LIMA, Paula Coelho Magalhães de. A Exposição de 1917 em São Paulo: representações do industrialismo na metrópole nascente. São Paulo, 2008. Relatório de Iniciação Científica apresentado à Fapesp - Museu Paulista, Universidade de São Paulo.

Losano, Mario G. Um precursor da ecologia no Brasil: Hermann von Ihering. Trad. Giacomina Faldini. Revista USP, 13, 1992, pp. 88-99. 
LOPES, Maria Margaret. O Brasil descobre a pesquisa científica: os museus e as ciências naturais no século XIX. São Paulo: Hucitec, 1997. (2ª . ed. 2009). Originalmente Tese (Doutorado) defendida na Faculdade de Filosofia, Letras e Ciências Humanas da Universidade de São Paulo em 1993.

. "Os catálogos de Hermann von Ihering: o archivo dos resultados obtidos na exploração científica do Brasil”. In: HeIzer, Alda; VIDEIRA, Antonio A. Passos (orgs.). Ciência, Civilização e República nos Trópicos. Rio de Janeiro: Mauad/Faperj, 2010, pp. 291-304.

. Culturas científicas no início do século XIX: um estudo sobre as pontes continentais de Hermann von lhering (1850-1930). In: SCIENTIARUM HISTORIA CONGRESSO dE HistÓRIA dAS CiênCIAS E dAS TÉCNICAS E EPISTEMOlOGIA, 4, 2011, Rio de Janeiro. Anais... Rio de Janeiro: Programa de Pós-graduação em História das Ciências e das Técnicas e Epistemologia - UFRJ, 2011. Disponível em http://www.hcte.ufrj.br/downloads/sh/sh4/palestrantes/palestrante\%20MARIA\%20 MAGARET.pdf. Acesso em: 16 jul. 2012.

"Trajetórias museológicas, biografias de objetos, percursos metodológicos". In: AlmeidA, Marta de; VergarA, Moema de Rezende (orgs.). Ciência, história e historiografia. São Paulo: Via Lettera; Rio de Janeiro: MAST, 2008, pp. 305-318.

LOPES, Maria Margaret; FIgUeIRÔA, Silvia Fernanda de Mendonça. A criação do Museu Paulista na correspondência de Hermann von Ihering (1850-1930). Anais do Museu Paulista, nova série, 10/11, 2002-2003, pp. 23-35.

MaKINO, Miyoko. Cronologia do Museu Paulista/USP. Diário Oficial do Estado de São Paulo, 107, 220, 15 nov. 1997, pp. 1-3.

MARTINS, Ana Luiza. Revistas em revista: imprensa e práticas culturais em tempos de República, São Paulo (1890-1922). São Paulo: Edusp/Fapesp/Imprensa Oficial do Estado, 2001. Originalmente Tese (Doutorado) defendida na Faculdade de Filosofia, Letras e Ciências Humanas da Universidade de São Paulo em 1997. 
MARTins, Mariana Esteves. A formação do Museu Republicano "Convenção de Itu" (1921-1946). São Paulo, 2012. Dissertação (Mestrado) - Faculdade de Filosofia, Letras e Ciências Humanas, Universidade de São Paulo.

MARVIN, Garry. "Enlivened through memory: hunters and hunting trophies". In: AlberTI, Samuel J. M. M. (org.). The Afterlives of Animals: A Museum Menagerie. Charlottesville and London: University of Virginia Press, 2011.

MENESES, Ulpiano Toledo Bezerra de. A cultura material no estudo das sociedades antigas. Revista de História, 115, 1983, pp. 103-17.

Fontes visuais, cultura visual, História visual. Balanço provisório, propostas cautelares. Revista Brasileira de História, 23, 45, 2003, pp. 11-36.

MORAES, Fábio Rodrigo de. Uma coleção de história em um museu de ciências naturais: o Museu Paulista de Hermann von Ihering. Anais do Museu Paulista, nova série, 16, 1, jan-jun. 2008, pp. 203-233.

NYHART, Lynn K. Modern Nature: The Rise of the Biological Perspective in Germany. Chicago: University of Chicago Press, 2009.

Podgorny, Irina. Mercaderes del pasado: Teodoro Vilardebó, Pedro de Angelis y el comercio de huesos y documentos en el Río de la Plata, 1830-1850. Circumscribere: International Journal for the History of Science, 9, 2011, pp. 2977.

PODGORNY, Irina; LOPES, Maria Margaret. Trayectorias y desafíos de la historiografía de los museos de historia natural em América del Sur. Anais do Museu Paulista, nova série, 21, 1, jan-jun. 2013, pp. 15-25.

Poulot, Dominique. Another History of Museums: from the Discourse to the Museum-Piece. Anais do Museu Paulista, nova série, 21, 1, jan-jun. 2013, pp. 2747.

Rasmussen, Claus; Garcete-BarRett, Bolívar Rafael; Gonçalves, Rodrigo B. Curt Schrottky (1874-1937): South American entomology at the beginning of the 20th century (Hymenoptera, Lepidoptera, Diptera). Zootaxa, 2282, 2009, pp. 1-50. 
REDE, Marcelo. História a partir das coisas: tendências recentes nos estudos de cultura material. Anais do Museu Paulista, nova série, 4, 1996, pp. 265-282.

ReILING, Henri; SpunAROvÁ, Tat'jána. Václav Frič (1839-1916) and his influence on collecting natural history. Journal of the History of Collections, 17, 1, 2005, pp. 2343.

SÁ, Magali Romero. "A ciência, as viagens de coleta e as coleções: medicina tropical e o inventário da história natural na Primeira República”. In: HEIZER, Alda; VIDEIRA, Antonio A. Passos (orgs.). Ciência, Civilização e República nos Trópicos. Rio de Janeiro: Mauad/Faperj, 2010, pp. 227-243.

Sanjad, Nelson. A Coruja de Minerva: o Museu Paraense entre o Império e a República (1866-1907). Brasília: Instituto Brasileiro de Museus; Rio de Janeiro: Fundação Oswaldo Cruz, 2010.

SANJAD, Nelson et al. Documentos para a história do mais antigo jardim zoológico do Brasil: o Parque Zoobotânico do Museu Goeldi. Boletim do Museu Paraense Emílio Goeldi. Ciências Humanas, 7, 1, jan.-abr. 2012, pp. 197-258.

SCHWARCZ, Lilia Moritz. O espetáculo das raças: cientistas, instituições e questões raciais no Brasil (1870-1930). São Paulo: Cia. das Letras, 1993. Originalmente Tese (Doutorado) defendida na Faculdade de Filosofia, Letras e Ciências Humanas da Universidade de São Paulo em 1992.

Seebold, T. L. F. Notice Nécrologique sur le Dr. Otto Staudinger. Annales de la Société Entomologique de France, 70, 1901, pp. 6-7. Disponível em: https://archive.org/stream/annalesdelasoci701901soci\#page/6/mode/2up. Acesso em: abril de 2012.

SheEts-Pyenson, Susan. Cathedrals of science: the development of colonial Natural History museums during the late nineteenth century. Montreal: McGill-Queen's University Press, 1988

Silva, Maurício Cândido da. Christiano Stockler das Neves e o Museu de Zoologia da Universidade de São Paulo. São Paulo, 2006. Dissertação (Mestrado) Faculdade de Arquitetura e Urbanismo, Universidade de São Paulo. 
Straube, Fernando C.; Willis, Edwin O.; ONIKI, Yoshika. Aves colecionadas na localidade de Fazenda Caiuá (Paraná, Brasil) por Adolph Hempel, com discussão sobre a sua localização exata. Ararajuba, 10, 2, 2002, pp. 167-172.

VIDAL, Diana Gonçalves. "O Museu Escolar Brasileiro: Brasil, Portugal e a França no âmbito de uma história conectada (final do século XIX)". In: Lopes, Alberto; FARIA FILHO, Luciano Mendes de; FeRnANDES, Rogério. Para a compreensão histórica da infância. Belo Horizonte: Autêntica, 2007, pp. 199-220.

Weltman, Wanda Latmann. A educação do Jeca: ciência, divulgação científica e agropecuária na Revista Chácaras e Quintais (1909-1948). Rio de Janeiro, 2008. Tese (Doutorado) - Casa de Oswaldo Cruz, Fundação Oswaldo Cruz. 


\section{Apêndices}

\section{Apêndice A - Formas de aquisição dos espécimes da coleção de aves do Museu Paulista no período lhering ${ }^{343}$}

\begin{tabular}{|l|l|l|}
\hline Forma de aquisição & Número de espécimes & Percentual \\
\hline Coletado pelos funcionários do Museu & 4.728 & $58,7 \%$ \\
\hline Comprado de caçadores no Brasil & 940 & $11,7 \%$ \\
\hline Comprado de revendedores fora do país & 763 & $9,5 \%$ \\
\hline Permuta & 546 & $6,8 \%$ \\
\hline Doação & 68 & $0,8 \%$ \\
\hline Não foi possível definir & 1.006 & $12,5 \%$ \\
\hline Total & 8.051 & $100 \%$ \\
\hline
\end{tabular}

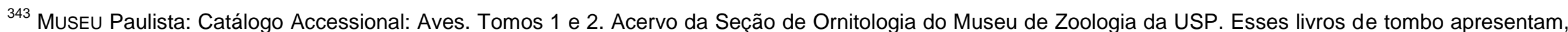

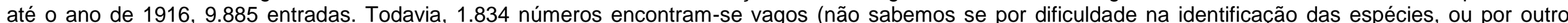

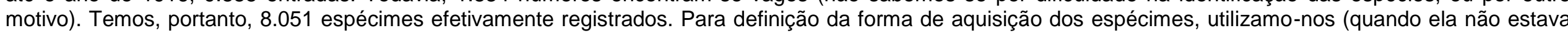

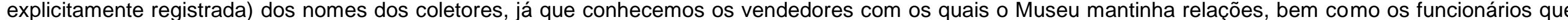

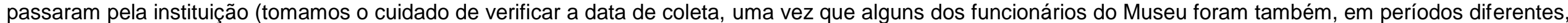

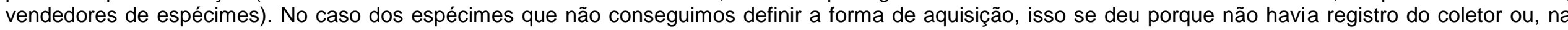

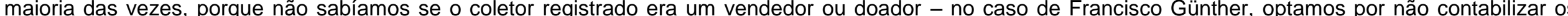

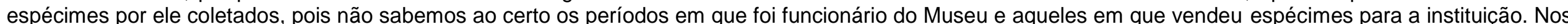
apêndices B, C e D podem ser conferidas listagens dos funcionários do Museu e dos comerciantes com os quais ele manteve relações.
} 


\section{Apêndice B - Funcionários técnicos e científicos do Museu Paulista entre 1894 e $1916^{344}$}

\begin{tabular}{|c|c|c|c|}
\hline Nome & Cargo & Período & Dados biográficos \\
\hline $\begin{array}{l}\text { Hermann Friedrich } \\
\text { Albrecht von Ihering } \\
(1850-1930)\end{array}$ & Diretor & $1894-1916$ & $\begin{array}{l}\text { Nascido em Kiel, Alemanha. Filho do famoso jurista alemão Rudolph von } \\
\text { Ihering. Formado em medicina e ciências naturais, Ihering deu início a uma } \\
\text { carreira acadêmica em universidades alemãs, interrompida por conta de sua } \\
\text { mudança para o Brasil em } 1880 \text {. Aqui, passou a residir no Rio Grande do Sul, } \\
\text { tendo sido naturalista viajante do Museu Nacional entre } 1883 \text { e } 1891 \text {. Após o fim } \\
\text { de sua gestão como diretor do Museu Paulista (1894-1916), passou algum } \\
\text { tempo na Argentina antes de retornar para a Alemanha. }{ }^{345}\end{array}$ \\
\hline Constantino Hilger & $\begin{array}{l}\text { Zelador ou } \\
\text { Custos }\end{array}$ & $1894-?^{346}$ & \\
\hline Luiz Reh & $\begin{array}{l}\text { Zelador ou } \\
\text { Custos }\end{array}$ & 1896 & Nascido na Alemanha \\
\hline $\begin{array}{l}\text { William J. } \\
\text { Moenkhaus (1871- } \\
\text { 1947) }\end{array}$ & $\begin{array}{l}\text { Zelador ou } \\
\text { Custos }\end{array}$ & $\begin{array}{l}\text { Meados de } 1897 \text { a } \\
\text { meados de } 1898\end{array}$ & $\begin{array}{l}\text { Nascido em Indiana, Estados unidos. Começou a lecionar na Universidade de } \\
\text { Indiana em } 1901 .{ }^{347}\end{array}$ \\
\hline Adolph Hempel & Entomologista (?- & $?-1900$ & Nascido em Buffalo, Ohio, nos EUA. Formou-se naturalista em 1892, tendo \\
\hline
\end{tabular}

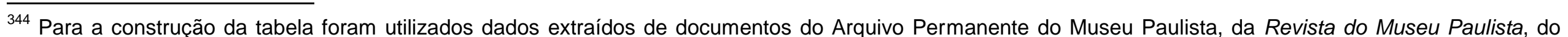

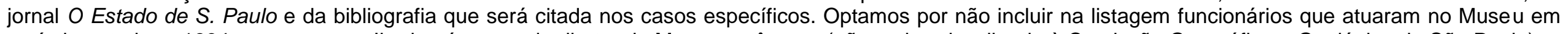

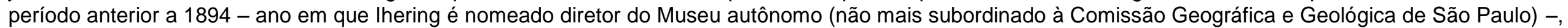

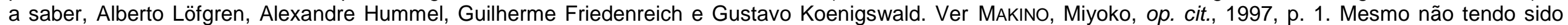

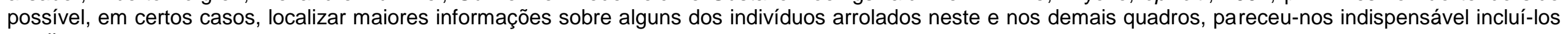
nas listagens.

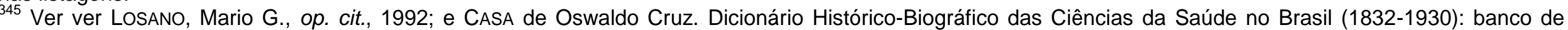
dados. Disponível em: http://www.dichistoriasaude.coc.fiocruz.br/iah/pt/index.php. Acesso em agosto de 2013.

${ }^{346}$ DIÁRIO Oficial do Estado de S. Paulo, 4, 996, 20 out. 1894. Disponível em: http://www.imprensaoficial.com.br/. Acesso em: agosto de 2013.

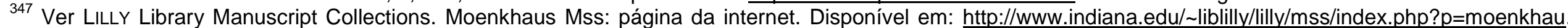
Acesso em: 9 de out. de 2013 


\begin{tabular}{|c|c|c|c|}
\hline Nome & Cargo & Período & Dados biográficos \\
\hline$(1870-1950)$ & $\begin{array}{l}\text { 1898) e Zelador } \\
\text { ou Custos (1898- } \\
1900)\end{array}$ & & $\begin{array}{l}\text { vindo para o Brasil poucos anos depois. Contratado inicialmente como } \\
\text { entomologista, depois, em 1898, passou a ocupar o cargo de zelador. Deixou o } \\
\text { Museu em 1900. Depois disso, atuou no Instituto Agronômico de Campinas e no } \\
\text { Instituto Biológico. }\end{array}$ \\
\hline $\begin{array}{l}\text { Curt Schrottky } \\
(1874-1937)\end{array}$ & $\begin{array}{l}\text { Zelador ou } \\
\text { Custos }\end{array}$ & $\begin{array}{l}27 / 04 / 1900 a \\
05 / 08 / 1901\end{array}$ & $\begin{array}{l}\text { Zelador do Museu Paulista entre abril de } 1900 \text { e agosto de 1901. Ocupou o } \\
\text { cargo de preparador antes disso. Nascido em Petrokov, Rússia (cidade hoje } \\
\text { situada na Polônia), Schrottky possuía cidadania alemã e frequentou colégios } \\
\text { em Berlim e Breslau (cidade hoje situada na Polônia). Em } 1902 \text { mudou-se para } \\
\text { a Argentina e em seguida para o Paraguai, de onde passou a manter, a partir } \\
\text { de 1909, correspondência com Hermann von Ihering. }{ }^{349}\end{array}$ \\
\hline $\begin{array}{l}\text { Rodolpho Theodor } \\
\text { Wilhelm Gaspar von } \\
\text { Ihering (1883-1939) }\end{array}$ & $\begin{array}{l}\text { Zelador ou } \\
\text { Custos }\end{array}$ & $\begin{array}{l}27 \text { de janeiro de } \\
1902 \text { a } 1917\end{array}$ & $\begin{array}{l}\text { Filho de Hermann von Ihering, nasceu em Taquara do Novo Mundo, Rio Grande } \\
\text { do Sul. Formou-se bacharel em Ciências e Letras em 1901. Posteriormente } \\
\text { complementou sua formação em institutos científicos europeus. }\end{array}$ \\
\hline João Zech & $\begin{array}{l}\text { Naturalista } \\
\text { viajante }\end{array}$ & 1895-? & $\begin{array}{l}\text { Em } 1906 \text { envia duas cartas redigidas em alemão ao diretor do Museu Paulista, } \\
\text { tratando da venda de placas de turfa para insetos, adquiridas de Staudinger. }\end{array}$ \\
\hline $\begin{array}{l}\text { Ernesto Garbe } \\
(1853-1925) \\
\text { [Ernst Garbe] }\end{array}$ & $\begin{array}{l}\text { Naturalista } \\
\text { viajante }\end{array}$ & $\begin{array}{l}02 \text { de janeiro de } \\
1902 \text { a } 1925\end{array}$ & $\begin{array}{l}\text { Em dezembro de } 1901 \text { partiu em expedição ao Rio Juruá, Amazonas, de onde } \\
\text { retornou em dezembro de 1902. Durante a viagem, assumiu por procuração o } \\
\text { cargo de naturalista viajante do Museu Paulista (desde janeiro de 1902), que } \\
\text { ocupou até falecer. Nascido em Görlitz, Alemanha. Trabalhou para o fornecedor } \\
\text { mundial de animais selvagens Karl Hagenbeck, de Hamburgo. Foi nessa }\end{array}$ \\
\hline
\end{tabular}

${ }^{348}$ Ver StRaUBe, Fernando C.; WILlIS, Edwin O.; ONIKI, Yoshika, op. cit., 2002, p. 167. Cf. também IHeRING, Hermann von. O Museu Paulista em 1899 e 1900. Revista do Museu Paulista, 5, 1902, p. 2; e IDE, S. et al. Coleção Entomológica "Adolph Hempel", Instituto Biológico, São Paulo: História, importância e função. Páginas do Instituto Biológico, 1, 1, jan.-jun. 2005.

349 Ver RASMUSSEN, Claus; GARCETE-BARRETT, Bolívar Rafael; GonÇALVES, Rodrigo B. Curt Schrottky (1874-1937): South American entomology at the beginning of the 20th century (Hymenoptera, Lepidoptera, Diptera). Zootaxa, 2282, 2009, pp. 2-8; e TERMO de contrato de Curt Schrottky para o cargo de Zelador do Museu Paulista, São Paulo, 27/04/1900. APMP/FMP, Série Termos de compromisso de funcionários..

350 CASA de Oswaldo Cruz. Dicionário Histórico-Biográfico das Ciências da Saúde no Brasil (1832-1930): banco de dados. Disponível em: http://www.dichistoriasaude.coc.fiocruz.br/iah/pt/index.php. Acesso em agosto de 2013. 


\begin{tabular}{|c|c|c|c|}
\hline Nome & Cargo & Período & Dados biográficos \\
\hline & & & $\begin{array}{l}\text { condição que veio ao Brasil pela primeira vez, em 1882, tendo levado daqui } \\
\text { para Hamburgo grande quantidade de animais vivos e mortos. Veio } \\
\text { definitivamente para o Brasil em 1888, com a mulher Anna e o filho Walter. }{ }^{351}\end{array}$ \\
\hline $\begin{array}{l}\text { Rodolpho } \\
\text { Lautenbach }\end{array}$ & Entomologista & $1895 ?-1896 ?$ & \\
\hline $\begin{array}{l}\text { Hermann Lüderwaldt } \\
(1865-1934)\end{array}$ & $\begin{array}{l}\text { Preparador } \\
\text { auxiliar e } \\
\text { Preparador da } \\
\text { Seção } \\
\text { entomológica }\end{array}$ & 1905-? & $\begin{array}{l}\text { Nascido em Gollnow, cidade então na Alemanha, atualmente na Polônia. Veio } \\
\text { para o Brasil já adulto, passando a residir na colônia de Blumenau em } 1897 . \\
\text { Aqui trabalhou como derrubador de mata e agricultor. Em } 1905 \text { foi contratado } \\
\text { pelo Museu Paulista, inicialmente como jardineiro, logo passando a preparador } \\
\text { auxiliar (provavelmente no ano seguinte). Mais tarde tornou-se preparador da } \\
\text { seção entomológica (assim aparece em 1911, mas não sabemos quando } \\
\text { assumiu o cargo) e entomologista (não sabemos em que data). Mais tarde, já na } \\
\text { gestão Taunay, passou a Custos e depois, após a reformulação do regimento } \\
\text { do Museu, Assistente de Zoologia. }\end{array}$ \\
\hline $\begin{array}{l}\text { Francisco Günther ( } \\
\text { - 1912) } \\
\text { [Franz Günther] }\end{array}$ & $\begin{array}{l}\text { Preparador } \\
\text { auxiliar de } \\
\text { entomologia }\end{array}$ & $\begin{array}{l}\text { Setembro de } 1911 \text { a } \\
\text { janeiro de } 1912\end{array}$ & $\begin{array}{l}\text { Desenhista e preparador auxiliar de entomologia do Museu Paulista de } \\
\text { setembro de } 1911 \text { a janeiro de } 1912 \text { (data de sua morte). Já havia ocupado } \\
\text { anteriormente o cargo de preparador auxiliar por dois anos. Em 1905, } \\
\text { acompanhou (como naturalista contratado do Museu Paulista) expedição da } \\
\text { Comissão Geográfica e Geológica à região do rio Feio (oeste paulista). Vendeu } \\
\text { espécimes para o Museu entre } 1905 \text { e 1911. Sua correspondência enviada ao } \\
\text { diretor do Museu (na maioria das vezes proveniente do litoral de São Paulo) era } \\
\text { redigida em alemão. }\end{array}$ \\
\hline
\end{tabular}

351 Ver TERMO de contrato de Ernesto Garbe para o cargo de naturalista viajante do Museu Paulista. APMP/FMP, Série Termos de compromisso de funcionários (1894-1904); TAUNAY, Affonso de E. O naturalista Ernesto Garbe. Correio Paulistano, 05/07/1925. APMP/FMP, Série Matérias jornalísticas sobre o Museu Paulista; e ARQUIVo Público do Estado de São Paulo. Livros de Registro da Hospedaria de Imigrantes: banco de dados. Disponível em: http://www.arquivoestado.sp.gov.br/livros estrangeiros.php. Acesso em: agosto de 2013.

${ }^{352}$ TAUNAY, Affonso de E. Hermann Luederwaldt - assistente de zoologia do Museu Paulista. O Estado de S. Paulo, 17/08/1934, p. 4. 


\begin{tabular}{|c|c|c|c|}
\hline Nome & Cargo & Período & Dados biográficos \\
\hline Emilio Schneidt & Preparador & $1894^{353}-?$ & \\
\hline Sebastião Marques & Preparador & Abril-agosto de 1895 & \\
\hline Beniamino Bicego & Preparador & $\begin{array}{l}\text { Novembro de } 1895 \text { a } \\
\text { fevereiro de } 1897 \\
\text { (preparador); } \\
\text { fevereiro de } 1897 \text { a } \\
\text { junho de } 1898 \\
\text { (naturalista viajante) }\end{array}$ & Italiano, chegou ao Brasil em 1891, com 42 anos de idade. ${ }^{354}$ \\
\hline $\begin{array}{l}\text { Hellmuth Pinder } \\
(1874-1918)\end{array}$ & Preparador & 1896 a 1900 & $\begin{array}{l}\text { Nasceu em Kassel, Alemanha. Veio para o Brasil em 1895. Ocupou o cargo de } \\
\text { preparador do Museu Paulista entre } 1896 \text { e } 1900 \text {. Segundo Camargo, Pinder } \\
\text { deve ter deixado seu emprego no Museu no final do ano de } 1900 \text { para atuar } \\
\text { como comerciante de peles de aves. Morou em São Sebastião e em Santos, } \\
\text { tendo ocupado, nos anos finais de sua vida, o cargo de oficial aduaneiro na } \\
\text { Alfândega de Santos. }{ }^{355}\end{array}$ \\
\hline Luiz Tschümperli & Preparador & $\begin{array}{l}27 \text { de Abril a } 24 \text { de } \\
\text { Setembro de } 1900\end{array}$ & \\
\hline $\begin{array}{l}\text { Guilherme Ehrhardt } \\
\text { (1860-1936?) } \\
\text { [Wilhelm Ehrhardt] }\end{array}$ & Preparador & & $\begin{array}{l}\text { Foi preparador do Museu Paulista. Afastou-se do cargo em 1901. Nascido na } \\
\text { Guiana, descendente de imigrantes alemães, Ehrhardt mudou-se para a } \\
\text { Alemanha não se sabe em que data, de onde embarcou para o Brasil em } 1897 \\
\text { Aqui, instalou-se na Colônia Hansa Humbolt (hoje município de Corupá), Santa } \\
\text { Catarina, tendo atuado como coletor de espécimes, os quais fornecia para } \\
\text { diversos museus alemães e também para o British Museum (Natural History), }\end{array}$ \\
\hline
\end{tabular}

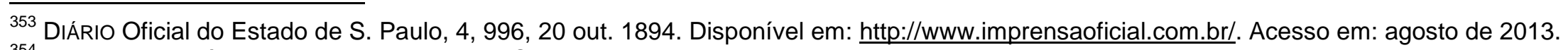

ARQUIVo Público do Estado de São Paulo. Livros de Registro da Hospedaria de Imigrantes: banco de dados. Disponível em: http://www.arquivoestado.sp.gov.br/livros estrangeiros.php. Acesso em: agosto de 2013.
}

${ }^{355}$ Ver CAmARGO, Hélio F. de Almeida, op. cit., 1998. 


\begin{tabular}{|c|c|c|c|}
\hline Nome & Cargo & Período & Dados biográficos \\
\hline & & & $\begin{array}{l}\text { em Londres. Não se sabe quando foi contratado pelo Museu Paulista, mas em } \\
1901 \text { se afasta do seu cargo e vai para Santa Catarina, de onde envia } \\
\text { espécimes para o Museu, sendo seus vencimentos de preparador descontados } \\
\text { do valor total das coleções que enviava. }\end{array}$ \\
\hline $\begin{array}{r}\text { Carlos Schröter } \\
(1876-)\end{array}$ & Preparador & $\begin{array}{l}13 \text { de junho de } 1901 \\
\text { a } 01 / 01 / 1905\end{array}$ & $\begin{array}{l}\text { Nascido em Coburg, Alemanha. Aprendeu a taxidermizar em oficina situada em } \\
\text { Skaisgirren, então Alemanha, entre abril de } 1896 \text { e novembro de } 1897 .\end{array}$ \\
\hline João Leonardo Lima & Preparador & 1903-? & $\begin{array}{l}\text { Em dezembro de } 1903 \text { é nomeado preparador substituto. Em janeiro de } 1906 \\
\text { passa a titular do cargo. Antes de } 1903 \text { já atuava como servente do Museu. }\end{array}$ \\
\hline Henrique Schwebel & $\begin{array}{l}\text { Preparador } \\
\text { auxiliar }\end{array}$ & $1911-1915$ & \\
\hline Bento Barbosa & Desenhista & $\begin{array}{l}\text { Fevereiro de } 1912 \text { a } \\
31 \text { de outubro de } \\
1915\end{array}$ & \\
\hline $\begin{array}{l}\text { Paulo Vergueiro } \\
\text { Lopes de Leão } \\
(1889-1964)\end{array}$ & Desenhista & 1915 a 1917 & $\begin{array}{l}\text { Pintor e gravador paulista. Formou-se em Direito pela Faculdade de Direito do } \\
\text { Largo de São Francisco. Tendo obtido pensão do governo paulista, estudou } \\
\text { gravura e pintura em Florença e Paris. }{ }^{357}\end{array}$ \\
\hline
\end{tabular}

$\overline{356}$ Ver GUTSCHE, Alexander et al. Wilhelm Ehrhardt and an evaluation of his amphibians and reptiles held in the Herpetological Collection of the Museum für Naturkunde, Berlin. Mitteilungen aus dem Museum für Naturkunde in Berlin - Zoologische Reihe, 83, 1, 2007, pp. 80-83; e CARTA de Hermann von Ihering a Guilherme Ehrhardt, São Paulo, 20/04/1901. APMP/FMP, Série Correspondência.

${ }^{357}$ ITAÚ Cultural. Enciclopédia de artes visuais: banco de dados. Disponível em: http://www.itaucultural.org.br/aplicexternas/enciclopedia ic/. Acesso em: 13 de dezembro de 2013. 


\section{Apêndice C - Coletores residentes no Brasil que venderam espécimes ao Museu Paulista entre 1894 e $1916^{358}$}

\begin{tabular}{|c|c|c|c|c|c|}
\hline Coletor & $\begin{array}{l}\text { Locais de } \\
\text { coleta }\end{array}$ & $\begin{array}{l}\text { Período } \\
\text { das } \\
\text { remessas }\end{array}$ & $\begin{array}{l}\text { Remes- } \\
\text { sas }\end{array}$ & Tipo de material & Dados biográficos \\
\hline Mathias Wacket & $\begin{array}{l}\text { Região de } \\
\text { Paranapia- } \\
\text { caba, SP }\end{array}$ & $\begin{array}{l}1901 \mathrm{a} \\
1910\end{array}$ & 20 & $\begin{array}{l}\text { Diversos tipos de animais, } \\
\text { principalmente insetos. } \\
\text { Também uma remessa de } \\
\text { plantas. }\end{array}$ & \\
\hline $\begin{array}{l}\text { Ricardo Krone } \\
(1861-1917)\end{array}$ & Iguape, SP & $\begin{array}{l}1894 \text { a } \\
1903 \text { (uma } \\
\text { remessa } \\
\text { em 1909) }\end{array}$ & 14 & $\begin{array}{l}\text { Principalmente couros, } \\
\text { ovos e ninhos de aves. } \\
\text { Mas também diversos } \\
\text { outros tipos de animais, } \\
\text { por exemplo peixes e } \\
\text { mamíferos. }\end{array}$ & $\begin{array}{l}\text { Natural de Dresden, Alemanha, veio para o Brasil em } 1884 \text {, } \\
\text { após concluir seus estudos de engenheiro geógrafo em sua } \\
\text { terra natal. Aqui, trabalhou inicialmente como engenheiro e } \\
\text { agrimensor. Mais tarde, residindo em lguape, onde também } \\
\text { trabalhava como farmacêutico, Krone atuou como fornecedor } \\
\text { de espécimes para diversos museus do mundo. }{ }^{359}\end{array}$ \\
\hline $\begin{array}{l}\text { Christiano } \\
\text { Enslen }\end{array}$ & $\begin{array}{l}\text { São } \\
\text { Lourenço, } \\
\text { RS }\end{array}$ & $\begin{array}{l}1897 a \\
1915\end{array}$ & 13 & $\begin{array}{l}\text { Diversos tipos de animais, } \\
\text { plantas e, em pelo menos } \\
\text { uma oportunidade, objetos } \\
\text { etnográficos. }\end{array}$ & \\
\hline Otto Dreher & $\begin{array}{l}\text { Franca, SP } \\
\text { e Ponte Ipê } \\
\text { Arcado, GO }\end{array}$ & $\begin{array}{l}1902 \text { a } \\
1904 \text { (uma } \\
\text { remessa } \\
\text { em 1908) }\end{array}$ & 17 & Diversos tipos de animais. & \\
\hline
\end{tabular}

${ }_{358}$ A tabela apresenta dados biográficos e os principais locais de atuação dos coletores, o período no qual venderam espécimes ao Museu Paulista, o tipo de material e o número de remessas fornecidas ao Museu. O número de remessas foi determinado a partir da quantidade de recibos, bem como de referências constantes de outros documentos que indiquem o envio de remessas de espécimes ao Museu. Para a construção da tabela foram utilizados dados extraídos de documentos do Arquivo Permanente do Museu Paulista, da Revista do Museu Paulista e da bibliografia que será citada nos casos específicos.

${ }^{359}$ Ver ANÔNIMO, op. cit., 1918b, pp. 929-938. 


\begin{tabular}{|c|c|c|c|c|c|}
\hline Coletor & $\begin{array}{l}\text { Locais de } \\
\text { coleta }\end{array}$ & $\begin{array}{l}\text { Período } \\
\text { das } \\
\text { remessas }\end{array}$ & $\begin{array}{l}\text { Remes- } \\
\text { sas }\end{array}$ & Tipo de material & Dados biográficos \\
\hline $\begin{array}{l}\text { Hellmuth Pinder } \\
(1874-1918)\end{array}$ & $\begin{array}{l}\text { São Paulo, } \\
\text { São } \\
\text { Sebastião e } \\
\text { Santos, SP }\end{array}$ & $\begin{array}{l}1905 \mathrm{a} \\
1915\end{array}$ & 5 & $\begin{array}{l}\text { Couros e ovos de aves, } \\
\text { crâneos de índios e } \\
\text { fotografias. }\end{array}$ & $\begin{array}{l}\text { Nasceu em Kassel, Alemanha. Veio para o Brasil em } 1895 . \\
\text { Ocupou o cargo de preparador do Museu Paulista entre } 1896 \text { e } \\
\text { 1900. Segundo Camargo, Pinder deve ter deixado seu } \\
\text { emprego no Museu no final do ano de } 1900 \text { para atuar como } \\
\text { comerciante de peles de aves. Morou em São Sebastião e em } \\
\text { Santos, tendo ocupado, nos anos finais de sua vida, o cargo } \\
\text { de oficial aduaneiro na Alfândega de Santos. }^{360}\end{array}$ \\
\hline $\begin{array}{l}\text { Ferdinand } \\
\text { Schwanda } \\
\text { (morto em } \\
\text { 10/06/1913) e } \\
\text { seu filho J. Karl } \\
\text { Schwanda }\end{array}$ & \begin{tabular}{|l} 
Miritiba, \\
Maranhão
\end{tabular} & $\begin{array}{l}1906 \mathrm{a} \\
1915\end{array}$ & 11 & $\begin{array}{l}\text { Couros de aves e } \\
\text { mamíferos. }\end{array}$ & $\begin{array}{l}\text { Ferdinand Schwanda estabeleceu-se no Maranhão em 1905, } \\
\text { de onde enviou espécimes para diversos museus europeus, } \\
\text { como o Britsh Museum (Natural History), o Museu Real de } \\
\text { História Natural de Sófia, Bulgária, além dos museus de Viena, } \\
\text { Munique e Frankfurt am Main. Após sua morte, seu filho } \\
\text { continuou a fornecer espécimes para o Museu Paulista, } \\
\text { conforme atestam documentos encontrados no arquivo do } \\
\text { Museu. }\end{array}$ \\
\hline $\begin{array}{l}\text { Francisco } \\
\text { Günther ( - } \\
\text { 1912) } \\
\text { [Franz Günther] }\end{array}$ & $\begin{array}{l}\text { Ilhas do } \\
\text { litoral norte } \\
\text { de São } \\
\text { Paulo }\end{array}$ & $\begin{array}{l}1905 a \\
1911\end{array}$ & 19 & $\begin{array}{l}\text { Diversos tipos de animais, } \\
\text { principalmente peixes. }\end{array}$ & $\begin{array}{l}\text { Foi desenhista e preparador auxiliar de entomologia do Museu } \\
\text { Paulista de setembro de } 1911 \text { a janeiro de } 1912 \text { (data de sua } \\
\text { morte). Já havia ocupado anteriormente o cargo de preparador } \\
\text { auxiliar por dois anos. }\end{array}$ \\
\hline
\end{tabular}

\footnotetext{
${ }^{360}$ Ver CAMARGo, Hélio F. de Almeida, op. cit., 1998.

${ }^{361}$ Ver IHERING, Hermann von. Os bugios do genero Alouatta. Revista do Museu Paulista, 9, 1914, pp. 231-232; HeLLmAYR, Carl E., op. cit., 1929, pp. 235-39; e OBERÖSTERREICHISCHES Landesmuseen. Zobodat - Zoologisch-Botanische Datenbank: banco de dados. Disponível em: http://www.zobodat.at. Acesso em: março de 2012
} 


\begin{tabular}{|l|l|l|l|l|l|}
\hline Coletor & $\begin{array}{l}\text { Locais de } \\
\text { coleta }\end{array}$ & $\begin{array}{l}\text { Período } \\
\text { das } \\
\text { remessas }\end{array}$ & $\begin{array}{l}\text { Remes- } \\
\text { sas }\end{array}$ & Tipo de material & Dados biográficos \\
\hline $\begin{array}{l}\text { Adolph Hempel } \\
(1870-1950)\end{array}$ & Campinas & $\begin{array}{l}1900 \text { a } \\
1908\end{array}$ & 12 & $\begin{array}{l}\text { Principalmente couros, } \\
\text { ovos e ninhos de aves. } \\
\text { Mas também mamíferos, } \\
\text { conchas, insetos, ratoeiras } \\
\text { e uma rede de pesca. }\end{array}$ & $\begin{array}{l}\text { Nascido em Buffalo, Ohio, nos EUA. Formou-se naturalista em } \\
\text { 1892, tendo vindo para o Brasil poucos anos depois. Foi } \\
\text { entomologista e depois zelador do Museu Paulista. Depois } \\
\text { disso, atuou no Instituto Agronômico de Campinas e no } \\
\text { Instituto Biológico. }\end{array}$ \\
\hline $\begin{array}{l}\text { Benedicto } \\
\text { Pedroso }\end{array}$ & $\begin{array}{l}\text { Principalmente ninhos de } \\
\text { abelhas e vespas. }\end{array}$ & \\
\hline A. Devantier & $\begin{array}{l}\text { São } \\
\text { Lourenço, } \\
\text { RS }\end{array}$ & $\begin{array}{l}1890 \text { a a } \\
1901\end{array}$ & 3 & Insetos. & \\
\hline
\end{tabular}

${ }^{362}$ Ver StRaUBe, Fernando C.; WILlIS, Edwin O.; ONIKI, Yoshika, op. cit., 2002, p. 167. Cf. também IHeRING, Hermann von. O Museu Paulista em 1899 e 1900. Revista do Museu Paulista, 5, 1902, p. 2; e IDE, S. et al., op. cit., 2005. 


\begin{tabular}{|c|c|c|c|c|c|}
\hline Coletor & $\begin{array}{l}\text { Locais de } \\
\text { coleta }\end{array}$ & $\begin{array}{l}\text { Período } \\
\text { das } \\
\text { remessas }\end{array}$ & $\begin{array}{l}\text { Remes- } \\
\text { sas }\end{array}$ & Tipo de material & Dados biográficos \\
\hline $\begin{array}{l}\text { Guilherme } \\
\text { Ehrhardt (1860- } \\
1936 ?) \\
\text { [Wilhelm } \\
\text { Ehrhardt] }\end{array}$ & \begin{tabular}{|l} 
Santa \\
Catarina e \\
Santos
\end{tabular} & $\begin{array}{l}1901 \text { a } \\
1908 \text { (e } \\
\text { uma carta } \\
\text { enviada } \\
\text { em 1916) }\end{array}$ & 4 & Diversos tipos de animais. & $\begin{array}{l}\text { Foi preparador do Museu Paulista. Afastou-se do cargo em } \\
\text { 1901. Nascido na Guiana, descendente de imigrantes } \\
\text { alemães, Ehrhardt mudou-se para a Alemanha não se sabe } \\
\text { em que data, de onde embarcou para o Brasil em 1897. Aqui, } \\
\text { instalou-se na Colônia Hansa Humbolt (hoje município de } \\
\text { Corupá), Santa Catarina, tendo atuado como coletor de } \\
\text { espécimes, os quais fornecia para diversos museus alemães e } \\
\text { também para o British Museum (Natural History), em Londres. } \\
\text { Não se sabe quando foi contratado pelo Museu Paulista, mas } \\
\text { em } 1901 \text { se afasta do Museu e vai para Santa Catarina, de } \\
\text { onde envia espécimes para o Museu Paulista, sendo seus } \\
\text { vencimentos de preparador descontados do valor total das } \\
\text { coleções que enviava. }\end{array}$ \\
\hline $\begin{array}{l}\text { Curt Schrottky } \\
(1874-1937)\end{array}$ & $\begin{array}{l}\text { Jundiaí e } \\
\text { Puerto } \\
\text { Bertoni } \\
\text { (Paraguai) }\end{array}$ & $\begin{array}{l}1899 \text { a } \\
1914\end{array}$ & 4 & Insetos. & $\begin{array}{l}\text { Foi zelador do Museu Paulista entre abril de } 1900 \text { e agosto de } \\
\text { 1901. Ocupou o cargo de preparador antes disso. Nascido em } \\
\text { Petrokov, Rússia (cidade hoje situada na Polônia), Schrottky } \\
\text { possuía cidadania alemã e frequentou colégios em Berlim e } \\
\text { Breslau (cidade hoje situada na Polônia). Em } 1902 \text { mudou-se } \\
\text { para a Argentina e em seguida para o Paraguai, de onde } \\
\text { passaria a manter, a partir de 1909, correspondência com } \\
\text { Hermann von Ihering. }{ }^{364}\end{array}$ \\
\hline
\end{tabular}

\footnotetext{
$\overline{363}$ Ver GUTSCHE, Alexander et al., op. cit., 2007, pp. 80-83; e CARTA de Hermann von Ihering a Guilherme Ehrhardt, São Paulo, 20/04/1901. APMP/FMP, Série Correspondência.

${ }^{364}$ Ver RASMUSSEN, Claus; GARCETE-BARRETT, Bolívar Rafael; GonÇALVES, Rodrigo B., op. cit., 2009, pp. 2-8; e TeRmo de contrato de Curt Schrottky para o cargo de Zelador do Museu Paulista, São Paulo, 27/04/1900. APMP/FMP, Série Termos de compromisso de funcionários.
} 


\begin{tabular}{|c|c|c|c|c|c|}
\hline Coletor & $\begin{array}{l}\text { Locais de } \\
\text { coleta }\end{array}$ & $\begin{array}{l}\text { Período } \\
\text { das } \\
\text { remessas }\end{array}$ & $\begin{array}{l}\text { Remes- } \\
\text { sas }\end{array}$ & Tipo de material & Dados biográficos \\
\hline $\begin{array}{l}\text { Beniamino } \\
\text { Bicego }\end{array}$ & & 1895 & 1 & $\begin{array}{l}\text { Répteis, insetos e } \\
\text { aracnídeos. }\end{array}$ & $\begin{array}{l}\text { Italiano, chegou ao Brasil em 1891, com } 42 \text { anos de idade. Foi } \\
\text { preparador e naturalista viajante do Museu Paulista. }{ }^{365}\end{array}$ \\
\hline $\begin{array}{l}\text { Borghesi } \\
\text { Claudio }\end{array}$ & & 1900 & 3 & Mamíferos. & \\
\hline $\begin{array}{l}\text { Carlos } \\
\text { Grossmam }\end{array}$ & & 1904 & 2 & Mamíferos e outros. & \\
\hline Paulo Friedrich & & 1905 & 2 & Insetos. & \\
\hline $\begin{array}{l}\text { Jacintho de } \\
\text { Godoy }\end{array}$ & & $\begin{array}{l}1905 a \\
1906\end{array}$ & 2 & Diversos tipos de animais. & \\
\hline Anton Rehz & & 19010 & 4 & Insetos. & \\
\hline Matth. Zish(?) & Ubatuba & 1898 & 1 & Borboletas. & \\
\hline João Zech & & 1898 & 1 & Aves. & $\begin{array}{l}\text { Contratado como naturalista viajante do Museu Paulista em } \\
\text { 1895. Não sabemos até quando ocupou o cargo. Em } 1906 \\
\text { envia duas cartas redigidas em alemão ao diretor do Museu } \\
\text { Paulista, tratando da venda de placas de turfa para insetos } \\
\text { adquiridas de Staudinger. }\end{array}$ \\
\hline
\end{tabular}

365 ARQUIVo Público do Estado de São Paulo. Livros de Registro da Hospedaria de Imigrantes: banco de dados. Disponível em: http://www.arquivoestado.sp.gov.br/livros estrangeiros.php. Acesso em: agosto de 2013. 


\begin{tabular}{|l|l|l|l|l|l|}
\hline Coletor & $\begin{array}{l}\text { Locais de } \\
\text { coleta }\end{array}$ & $\begin{array}{l}\text { Período } \\
\text { das } \\
\text { remessas }\end{array}$ & $\begin{array}{l}\text { Remes- } \\
\text { sas }\end{array}$ & Tipo de material & Dados biográficos \\
\hline $\begin{array}{l}\text { Ernesto Garbe } \\
(1853-1925)\end{array}$ & & $\begin{array}{l}1901 \text { a } \\
1907\end{array}$ & 6 & $\begin{array}{l}\text { Aves, mamíferos, insetos e } \\
\text { répteis. }\end{array}$ & $\begin{array}{l}\text { Em dezembro de 1901 partiu em expedição ao Rio Juruá, } \\
\text { Amazonas, de onde retornou em dezembro de 1902. Durante a } \\
\text { viagem, assumiu por procuração o cargo de Naturalista } \\
\text { viajante do Museu Paulista (desde janeiro de 1902), que } \\
\text { ocupou até falecer. Nascido em Görlitz, Alemanha. Trabalhou } \\
\text { para o fornecedor mundial de animais selvagens Karl } \\
\text { Hagenbeck, de Hamburgo. Foi nessa condição que veio ao } \\
\text { Brasil pela primeira vez em 1882, tendo levado daqui para } \\
\text { Hamburgo grande quantidade de animais vivos e mortos. Teria } \\
\text { vindo definitivamente para o Brasil em 1888, com a mulher } \\
\text { Anna e o filho Walter. }\end{array}$ \\
\hline
\end{tabular}

\footnotetext{
${ }^{366}$ Ver TERMO de contrato de Ernesto Garbe para o cargo de naturalista viajante do Museu Paulista. APMP/FMP, Série Termos de compromisso de funcionários (1894-1904); TAUNAY, Affonso de E. O naturalista Ernesto Garbe. Correio Paulistano, 05/07/1925. APMP/FMP, Série Matérias jornalísticas sobre o Museu Paulista; e ARQUivo Público do Estado de São Paulo. Livros de Registro da Hospedaria de Imigrantes: banco de dados. Disponível em: http://www.arquivoestado.sp.gov.br/livros estrangeiros.php. Acesso em: agosto de 2013.
} 


\section{Apêndice D - Negociantes de produtos de História Natural sediados no exterior com os quais o Museu Paulista manteve relações entre 1894 e $1916^{367}$}

\begin{tabular}{|c|c|c|c|c|c|c|}
\hline $\begin{array}{l}\text { Empresa/ } \\
\text { Negociante }\end{array}$ & Local & Proprietário & $\begin{array}{l}\text { Funda- } \\
\text { ção }\end{array}$ & $\begin{array}{l}\text { Remessas } \\
\text { para o MP }\end{array}$ & Tipo de matrial & Outros dados \\
\hline $\begin{array}{l}\text { Wilhelm Schlüter - } \\
\text { Naturhistorisches } \\
\text { Institut }\end{array}$ & $\begin{array}{l}\text { Halle an } \\
\text { der Saale, } \\
\text { Alemanha }\end{array}$ & $\begin{array}{l}\text { Wilhelm Schlüter } \\
(1828-1919)\end{array}$ & 1853 & 34 & $\begin{array}{l}\text { Diversos tipos } \\
\text { de animais, } \\
\text { suprimentos } \\
\text { para preparação } \\
\text { e } \\
\text { armazenamento } \\
\text { de espécimes, } \\
\text { entre outros. }\end{array}$ & $\begin{array}{l}\text { Wilhelm Schlüter, nascido na Alemanha, filho } \\
\text { de um entomólogo e malacologista, fundou em } \\
1853 \text { sua empresa fornecedora de espécimes e } \\
\text { suprimentos para História Natural, situada em } \\
\text { Halle an der Saale. A partir do final do século } \\
\text { XIX, a loja passou a ser dirigida por seus filhos. }\end{array}$ \\
\hline $\begin{array}{l}\text { Otto Staudinger \& } \\
\text { Andreas Bang- } \\
\text { Haas }\end{array}$ & $\begin{array}{l}\text { Dresden, } \\
\text { Alemanha }\end{array}$ & $\begin{array}{l}\text { Otto Staudinger } \\
(1830-1900) \& \\
\text { Andreas Bang- } \\
\text { Haas (1846- } \\
1925)\end{array}$ & 1858 & 13 & $\begin{array}{l}\text { Insetos e } \\
\text { alfinetes } \\
\text { entomológicos. }\end{array}$ & $\begin{array}{l}\text { Otto Staudinger foi um entomólogo alemão } \\
\text { especializado em lepidópteros, o qual passou a } \\
\text { comercializar espécimes de História Natural por } \\
\text { volta de } 1858 \text {. Em } 1879 \text { seu futuro genro, o } \\
\text { também entomólogo Andreas Bang-Haas, } \\
\text { tornou-se seu sócio na empresa sediada em } \\
\text { Dresden. }\end{array}$ \\
\hline Kosmos - & Berlim, & Franz Hermann & 1889 & 6 & Diversos tipos & O alemão Franz Hermann Rolle iniciou seu \\
\hline
\end{tabular}

\footnotetext{
${ }^{367}$ Para a construção desta tabela foram utilizados, além de documentos provenientes do Arquivo Permanente do Museu Paulista, dados retirados das seguintes fontes: ANÔNIMO. G. Baer. Bulletin de la Société Entomologique de France, 1918, pp. 53-54; HANCOCK, E. G.; HowELL, A. e TORRENS, H. S. Geological collections and collectors of note 11. Bolton Museum. Newsletter of the Geological Curators Group, 7, 1976, pp. 324-25; OBERÖSTERREICHISCHES Landesmuseen. Zobodat Zoologisch-Botanische Datenbank: banco de dados. Disponível em: http://www.zobodat.at. Acesso em: março de 2012; SENCKENBERG Deutsches Entomologisches Institut. Biografien der Entomologen der Welt: banco de dados. Disponível em: http://www.sdei.de/biographies/. Acesso em: junho de 2012; THE MINERALOGICAL Record: banco de dados. Disponível em: http://www.minrec.org/labelarchive.asp. Acesso em: junho de 2012; DEYROLLE. L'historique de la maison: página da internet. Disponível em: http://www.deyrolle.com/magazine/spip.php?article149. Acesso em: 15 de março de 2012.
} 


\begin{tabular}{|c|c|c|c|c|c|c|}
\hline $\begin{array}{l}\text { Empresa/ } \\
\text { Negociante }\end{array}$ & Local & Proprietário & $\begin{array}{l}\text { Funda- } \\
\text { ção }\end{array}$ & $\begin{array}{l}\text { Remessas } \\
\text { para o MP }\end{array}$ & Tipo de matrial & Outros dados \\
\hline $\begin{array}{l}\text { Naturhistorisches } \\
\text { Institut }\end{array}$ & Alemanha & Rolle (1864-1929) & & & de animais. & $\begin{array}{l}\text { negócio de venda de espécimes de História } \\
\text { Natural em } 1889 \text { em Berlim. }\end{array}$ \\
\hline $\begin{array}{l}\text { J. F. G. Umlauff - } \\
\text { Museum - } \\
\text { Naturalien } \\
\text { Handlung }\end{array}$ & $\begin{array}{l}\text { Hamburgo } \\
\text { Alemanha }\end{array}$ & $\begin{array}{l}\text { Johann Friedrich } \\
\text { Gustav Umlauff } \\
(1833-1889) \text { e } \\
\text { família }\end{array}$ & 1868 & 4 & $\begin{array}{l}\text { Objetos } \\
\text { etnológicos e } \\
\text { couros de } \\
\text { mamíferos, } \\
\text { répteis e } \\
\text { pássaros. }\end{array}$ & $\begin{array}{l}\text { Após casar-se, em 1863, com Caroline } \\
\text { Hagenbeck (1839-1918), irmã do comerciante } \\
\text { de animais Carl Hagenbeck (1844-1913), os } \\
\text { negócios de Johann Friedrich Gustav Umlauff } \\
\text { no ramo da História Natural tiveram impulso. } \\
\text { Instalada formalmente em 1868, a empresa iria } \\
\text { se tornar importante no ramo do comércio de } \\
\text { produtos de História Natural e Etnografia. }{ }^{368}\end{array}$ \\
\hline $\begin{array}{l}\text { W. F. H. } \\
\text { Rosenberg, F. Z. } \\
\text { S. - Naturalist and } \\
\text { Importer of Exotic } \\
\text { Zoological } \\
\text { Specimens }\end{array}$ & $\begin{array}{l}\text { Londres, } \\
\text { Inglaterra }\end{array}$ & $\begin{array}{l}\text { William Frederick } \\
\text { Henry Rosenberg } \\
(1868-1957)\end{array}$ & 1897 & 9 & $\begin{array}{l}\text { Mamíferos, } \\
\text { peixes, aves e } \\
\text { ovos de } \\
\text { pássaros. }\end{array}$ & $\begin{array}{l}\text { William Frederick Henry Rosenberg iniciou suas } \\
\text { atividades como comerciante de espécimes de } \\
\text { História Natural em 1897. Poucos anos antes } \\
\text { de abrir seu negócio, o próprio Rosenberg } \\
\text { realizou duas expedições à Colômbia e ao } \\
\text { Equador. Após dar início a sua empresa, } \\
\text { empregou por dois anos, } 1898 \text { e } 1899 \text {, } \\
\text { coletores nessas regiões, os quais lhe } \\
\text { abasteciam de espécimes. Também recebia } \\
\text { espécimes de diversos outros coletores } \\
\text { instalados em várias partes do globo. }\end{array}$ \\
\hline $\begin{array}{l}\text { Ward's Natural } \\
\text { Science } \\
\text { Establishment }\end{array}$ & $\begin{array}{l}\text { Rochester } \\
\text {, Nova } \\
\text { York, EUA }\end{array}$ & $\begin{array}{l}\text { Henry Augustus } \\
\text { Ward (1835- } \\
1906)\end{array}$ & 1862 & 1 & $\begin{array}{l}\text { Coleção de } 18 \\
\text { corais das } \\
\text { Antilhas. }\end{array}$ & $\begin{array}{l}\text { Nascido em Rochester, Nova York, Henry } \\
\text { Augustus Ward provinha de uma família de } \\
\text { ricos comerciantes. Após ter passado alguns } \\
\text { meses estudando com Louis Agassiz no }\end{array}$ \\
\hline
\end{tabular}

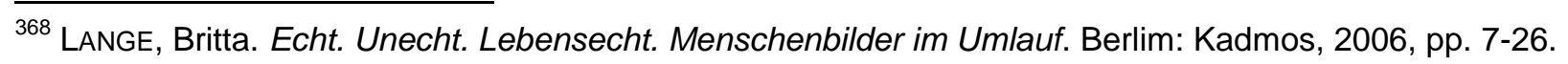




\begin{tabular}{|c|c|c|c|c|c|c|}
\hline $\begin{array}{l}\text { Empresa/ } \\
\text { Negociante }\end{array}$ & Local & Proprietário & $\begin{array}{l}\text { Funda- } \\
\text { ção }\end{array}$ & $\begin{array}{l}\text { Remessas } \\
\text { para o MP }\end{array}$ & Tipo de matrial & Outros dados \\
\hline & & & & & & $\begin{array}{l}\text { Museum of Comparative Zoology, Ward } \\
\text { embarca para a França em 1854, onde } \\
\text { frequentou cursos no Jardin de Plantes e na } \\
\text { École de Mines, além de ter participado de } \\
\text { expedições pela Europa, Oriente Médio e } \\
\text { África. De volta aos Estados Unidos seis anos } \\
\text { mais tarde, Ward passou a lecionar ciências } \\
\text { naturais na Universidade de Rochester e deu } \\
\text { início àquela que seria uma das maiores, mais } \\
\text { importantes e duradouras empresas de História } \\
\text { Natural da segunda metade do séc. XIX. }{ }^{369}\end{array}$ \\
\hline G. A. Baer & $\begin{array}{l}\text { Paris, } \\
\text { França }\end{array}$ & $\begin{array}{l}\text { Gustave Adolphe } \\
\text { Baer (1839-1918) }\end{array}$ & & 2 & $\begin{array}{l}\text { Mamíferos, } \\
\text { aves, ovos de } \\
\text { aves, } \\
\text { coleópteros. }\end{array}$ & $\begin{array}{l}\text { Nascido em Aarau, Suíça. Membro da Societé } \\
\text { Entomologique de France, da qual foi secretário } \\
\text { adjunto entre } 1886 \text { e 1896. Entre } 1867 \text { e } 1882 \\
\text { viveu nas Filipinas. Realizou expedições ao } \\
\text { Peru (entre } 1896 \text { e 1900) e a Goiás, Brasil } \\
\text { (entre } 1905 \text { e 1906). Como negociante de } \\
\text { produtos de História Natural, foi sucessor da } \\
\text { loja parisiense de Henri Guyon. }\end{array}$ \\
\hline $\begin{array}{l}\text { L. Eger - } \\
\text { Naturalien- und } \\
\text { Lehrmittel- } \\
\text { Comptoir }\end{array}$ & $\begin{array}{l}\text { Viena, } \\
\text { Áustria }\end{array}$ & Leopold Eger & & 2 & $\begin{array}{l}\text { Fósseis, peixes } \\
\text { empalhados e } \\
\text { modelos em } \\
\text { vidro de } \\
\text { diamantes e } \\
\text { outras pedras }\end{array}$ & \\
\hline
\end{tabular}

$\overline{369}$ BARROW, Mark V., op. cit., 2000, pp. 493-534 


\begin{tabular}{|c|c|c|c|c|c|c|}
\hline $\begin{array}{l}\text { Empresa/ } \\
\text { Negociante }\end{array}$ & Local & Proprietário & $\begin{array}{l}\text { Funda- } \\
\text { ção }\end{array}$ & $\begin{array}{l}\text { Remessas } \\
\text { para o MP }\end{array}$ & Tipo de matrial & Outros dados \\
\hline & & & & & preciosas. & \\
\hline & $\begin{array}{l}\text { Weymouth } \\
\text {, Inglaterra }\end{array}$ & $\begin{array}{l}\text { Robert Ferris } \\
\text { Damon (1845- } \\
\text { 1929) }\end{array}$ & & 2 & $\begin{array}{l}\text { Fósseis e } \\
\text { répteis. }\end{array}$ & $\begin{array}{l}\text { Possuía um empreendimento dedicado ao } \\
\text { comércio de produtos de História Natural } \\
\text { juntamente com seu pai, Robert Damon (1814- } \\
\text { 1889). }\end{array}$ \\
\hline $\begin{array}{l}\text { A. Krantz } \\
\text { (F. Krantz, a partir } \\
\text { do final do séc. } \\
\text { XIX) }\end{array}$ & $\begin{array}{l}\text { Bonn, } \\
\text { Alemanha }\end{array}$ & $\begin{array}{l}\text { Fundada por } \\
\text { August Krantz } \\
\text { (1809-1872). Seu } \\
\text { sobrinho Friedrich } \\
\text { Krantz (1859- } \\
\text { 1926) passou a } \\
\text { dirigir a empresa } \\
\text { em } 1891\end{array}$ & 1833 & 5 & $\begin{array}{l}\text { Conchas fósseis } \\
\text { e modelos em } \\
\text { gesso de } \\
\text { sáurios e de } \\
\text { crâneos de } \\
\text { hominídeos. }\end{array}$ & $\begin{array}{l}\text { August Krantz iniciou seu negócio dedicado à } \\
\text { venda de minerais ainda quando era estudante } \\
\text { na Academia de Minas de Freiberg. } \\
\text { Posteriormente, a loja mudaria para Berlim e, } \\
\text { em 1850, para Bonn, onde ficou em definitivo. } \\
\text { Após a morte de August Krantz, em 1872, seu } \\
\text { genro Theodor Hoffmann assumiu o negócio. } \\
\text { Em 1891, Friedrich Krantz, que, além de ser } \\
\text { sobrinho do fundador, havia estudado Química, } \\
\text { Farmacologia e Mineralogia (tendo obtido um } \\
\text { doutorado pela Universidade de Erlangen em } \\
\text { 1888), passou a dirigir a empresa. Esse } \\
\text { empreendimento foi uma das principais lojas } \\
\text { especializadas em artigos geológicos do } \\
\text { mundo. }\end{array}$ \\
\hline $\begin{array}{l}\text { Les Fils d'Émile } \\
\text { Deyrolle }\end{array}$ & $\begin{array}{l}\text { Paris, } \\
\text { França }\end{array}$ & $\begin{array}{l}\text { Fundada por } \\
\text { Jean-Baptiste } \\
\text { Deyrolle, o qual } \\
\text { foi sendo } \\
\text { sucedido por } \\
\text { seus } \\
\text { descendentes }\end{array}$ & 1831 & 2 & $\begin{array}{l}\text { Aquários, } \\
\text { armário para } \\
\text { preparações } \\
\text { microscópicas, } \\
\text { lupas e } \\
\text { instrumentos de } \\
\text { taxidermia. }\end{array}$ & $\begin{array}{l}\text { Iniciada como um negócio dedicado à venda de } \\
\text { insetos e de materiais para coleta de } \\
\text { espécimes, a Maison Deyrolle foi expandindo } \\
\text { seu campo de atuação no decorrer dos anos. } \\
\text { Editava e vendia livros de História Natural, além } \\
\text { de desenvolver e comercializar materiais } \\
\text { didáticos para o ensino de ciências naturais. }\end{array}$ \\
\hline
\end{tabular}




\begin{tabular}{|c|c|c|c|c|c|c|}
\hline $\begin{array}{l}\text { Empresa/ } \\
\text { Negociante }\end{array}$ & Local & Proprietário & $\begin{array}{l}\text { Funda- } \\
\text { ção }\end{array}$ & $\begin{array}{l}\text { Remessas } \\
\text { para o MP }\end{array}$ & Tipo de matrial & Outros dados \\
\hline & & & & & & $\begin{array}{l}\text { Como demonstrou Diana Vidal, esses materiais } \\
\text { didáticos eram adquiridos também por escolas } \\
\text { brasileiras, tendo sido inclusive realizada uma } \\
\text { adaptação e tradução para o português dos } \\
\text { painéis destinados ao ensino de ciências que } \\
\text { eram produzidos pela Deyrolle. }\end{array}$ \\
\hline $\begin{array}{l}\text { Comptoir } \\
\text { Ethnographique } \\
\text { Louis Exsteens }\end{array}$ & $\begin{array}{l}\text { Bruxelas, } \\
\text { Bélgica }\end{array}$ & & & 1 & $\begin{array}{l}\text { Objetos } \\
\text { arqueológicos } \\
\text { em sílex e em } \\
\text { material fundido. }\end{array}$ & \\
\hline \multirow[t]{2}{*}{$\begin{array}{l}\text { E. Le Moult - } \\
\text { Cabinet } \\
\text { Entomologique }\end{array}$} & $\begin{array}{l}\text { Paris, } \\
\text { França }\end{array}$ & $\begin{array}{l}\text { Eugène Le Moult } \\
(1882-1967)\end{array}$ & 1908 & - & & $\begin{array}{l}\text { O francês Eugène Le Moult, além de } \\
\text { negociante de espécimes, foi um entomólogo } \\
\text { especializado em Lepidóptera. Morou durante } \\
\text { algum tempo na Guiana. }{ }^{371} \text { Aparentemente, o } \\
\text { Museu Paulista não chegou a comprar } \\
\text { espécimes de Le Moult, mas existe uma carta } \\
\text { enviada por ele oferecendo insetos à instituição. }\end{array}$ \\
\hline & $\begin{array}{l}\text { Basileia, } \\
\text { Suiça }\end{array}$ & Gustav Schneider & & 1 & $\begin{array}{l}\text { Répteis, } \\
\text { anfíbios, corais } \\
\text { e equinodermes. }\end{array}$ & \\
\hline $\begin{array}{l}\text { Ernst A. Böttcher - } \\
\text { Naturalien- und } \\
\text { Lehrmittel-Anstalt }\end{array}$ & $\begin{array}{l}\text { Berlim, } \\
\text { Alemanha }\end{array}$ & $\begin{array}{l}\text { Ernst August } \\
\text { Böttcher }\end{array}$ & & 1 & Etiquetas. & \\
\hline
\end{tabular}

${ }^{370}$ VIDAL, Diana Gonçalves. "O Museu Escolar Brasileiro: Brasil, Portugal e a França no âmbito de uma história conectada (final do século XIX)". In: LOPES, Alberto; FARIA FILHO, Luciano Mendes de; FeRnANDES, Rogério. Para a compreensão histórica da infância. Belo Horizonte: Autêntica, 2007, pp. 199-220.

${ }^{371}$ Ver o verbete Eugène Le Moult na Wikipédia. Disponível em: http://en.wikipedia.org/wiki/Eug\%C3\%A8ne Le Moult. Acesso em: janeiro de 2014. 
Apêndice E - Áreas de interesse dos artigos de Zoologia publicados na Revista do Museu Paulista ${ }^{372}$

\begin{tabular}{|c|c|c|c|c|c|}
\hline Vol. & Autor & Título & Área & Categoria & $\begin{array}{l}\text { Usa } \\
\text { coleções }\end{array}$ \\
\hline 1 & H. von Ihering & Os crustaceos Phyllopodes do Brazil. & Sistemática & Complemento & Sim \\
\hline 1 & A. Lutz & Distoma opisthotrias, um novo parasita do gambá. & $\begin{array}{l}\text { Sistemática; } \\
\text { Estudo aplicado }\end{array}$ & Descrições novas & Sim \\
\hline 1 & H. von Ihering & O veneno ofídico. & $\begin{array}{l}\text { Biologia; Estudo } \\
\text { aplicado }\end{array}$ & - & Não \\
\hline 1 & H. von Ihering & Os Unionidos da Florida. & $\begin{array}{l}\text { Sistemática; } \\
\text { Biogeografia }\end{array}$ & $\begin{array}{l}\text { Revisão } \\
\text { taxonômica }\end{array}$ & Sim \\
\hline 2 & H. von Ihering & Os peixes da costa do mar no Estado do Rio Grande do Sul. & $\begin{array}{l}\text { Sistemática; } \\
\text { Biogeografia }\end{array}$ & Complemento & Não \\
\hline 2 & T. D. A. Cockerell & $\begin{array}{l}\text { Notes on the Coccidae, a family of Homoptera, with a table of } \\
\text { the species hitherto observed in Brazil. }\end{array}$ & Sistemática & Complemento & Não \\
\hline 2 & H. von Ihering & Os molluscos marinhos do Brazil. I Arcidae, Mytilidae. & Sistemática & Catálogo & Sim \\
\hline 2 & H. von Ihering & A llha de São Sebastião. & Biogeografia & - & Não \\
\hline 2 & A. E. Ortmann. & Os camarões da agua doce da America do Sul. & Sistemática & Catálogo & $\operatorname{Sim}(\mathrm{MP})$ \\
\hline 2 & T. D. A. Cockerell. & Further notes on Coccidae from Brazil. & Sistemática & $\begin{array}{l}\text { Identificação por } \\
\text { encomenda }\end{array}$ & $\operatorname{Sim}(\mathrm{MP})$ \\
\hline
\end{tabular}

\footnotetext{
$\overline{372}$ A listagem arrola os artigos zoológicos publicados nos nove primeiros volumes da Revista do Museu Paulista, suas áreas de interesse, categorias e se empregam coleções (caso sejam coleções do Museu Paulista, indica-se com a sigla "MP”). Para explicações mais detalhadas, ver o capítulo 2.
} 


\begin{tabular}{|c|c|c|c|c|c|}
\hline 2 & H. von Ihering & Os piolhos vegetaes (Phytophthires) do Brazil. & $\begin{array}{l}\text { Sistemática; } \\
\text { Biogeografia; } \\
\text { Estudo aplicado }\end{array}$ & Catálogo & $\operatorname{Sim}(\mathrm{MP})$ \\
\hline 2 & H. von Ihering & Os camarões da agua doce do Brazil. & Sistemática & Complemento & Não \\
\hline 3 & F. Mueller & Observações sobre a fauna marinha da costa de Sta. Catharina. & Biologia & - & Não \\
\hline 3 & T. D. A. Cockerell & Some new Coccidae, collected at Campinas, Brazil. & Sistemática & Descrições novas & Sim \\
\hline 3 & T. D. A. Cockerell & Some Coccidae collected by Dr. F. Noack at Campinas, Brazil. & Sistemática & $\begin{array}{l}\text { Identificação por } \\
\text { encomenda }\end{array}$ & Sim \\
\hline 3 & H. von Ihering & A doença das jaboticabeiras. & Estudo aplicado & - & Sim \\
\hline 3 & A. Hempel & Notas sobre Capulinia Jaboticabae Ihering. & $\begin{array}{l}\text { Biologia; Estudo } \\
\text { aplicado }\end{array}$ & - & Sim \\
\hline 3 & W. J. Moenkhaus. & Contribuição para o conhecimento das aranhas de S. Paulo. & Sistemática & Catálogo & Sim \\
\hline 3 & H. von Ihering & As aves do Estado de S. Paulo. & Sistemática & Catálogo & Não \\
\hline 3 & T. D. A. Cockerell & Mais algumas Coccidae colligidas pelo Dr. Noack. & Sistemática & $\begin{array}{l}\text { Identificação por } \\
\text { encomenda }\end{array}$ & Sim \\
\hline 4 & C. Euler & Descripção de ninhos e ovos das Aves do Brazil. & Biologia & - & Sim \\
\hline 4 & H. von Ihering & Aves observadas em Cantagallo e Nova Friburgo. & Sistemática & Catálogo & Não \\
\hline 4 & H. von Ihering & $\begin{array}{l}\text { Catalogo critico-comparativo dos ninhos e ovos das Aves do } \\
\text { Brazil. }\end{array}$ & Biologia & - & Sim (MP) \\
\hline
\end{tabular}




\begin{tabular}{|c|c|c|c|c|c|}
\hline 4 & P. A. Schupp & A Hyla pulchella Dum. Bibr. e a funcção chromatica. & Biologia & - & Não \\
\hline 4 & H. Sitter & Observações sobre alguns Caracóes terrestres do Brazil. & Sistemática & $\begin{array}{l}\text { Identificação por } \\
\text { encomenda }\end{array}$ & $\operatorname{Sim}(\mathrm{MP})$ \\
\hline 4 & $\begin{array}{l}\text { C. H. Eigennann \& } \\
\text { E. A. A. Norris }\end{array}$ & Sobre alguns Peixes de S. Paulo, Brazil. & Sistemática & $\begin{array}{l}\text { Identificação por } \\
\text { encomenda }\end{array}$ & $\operatorname{Sim}(\mathrm{MP})$ \\
\hline 4 & T. D. A. Cockerell & Notas sobre Coccidas. & Sistemática & $\begin{array}{l}\text { Identificação por } \\
\text { encomenda }\end{array}$ & Sim \\
\hline 4 & A. Hempel & As Coccidas brazileiras. & Sistemática & Catálogo & $\operatorname{Sim}(\mathrm{MP})$ \\
\hline 4 & H. von Ihering & Os Caracóes do genero Solaropsis. & Sistemática & $\begin{array}{l}\text { Revisão } \\
\text { taxonômica }\end{array}$ & $\operatorname{Sim}(\mathrm{MP})$ \\
\hline 5 & H.W. Brölemann, & Myriapodes du Musée de S. Paulo. & Sistemática & $\begin{array}{l}\text { Identificação por } \\
\text { encomenda }\end{array}$ & $\operatorname{Sim}(\mathrm{MP})$ \\
\hline 5 & H. von Ihering & Contribuições para o conhecimento da Ornithologia de S. Paulo. & $\begin{array}{l}\text { Sistemática; } \\
\text { Biologia }\end{array}$ & Complemento & $\operatorname{Sim}(\mathrm{MP})$ \\
\hline 5 & C. Schrottky & Ensaio sobre as Abelhas solitarias do Brazil. & Sistemática & Catálogo & $\operatorname{Sim}(\mathrm{MP})$ \\
\hline 5 & T. D. A. Cockerell & Nota sobre um Dactylopius achado em Fuchsia no Brazil. & Sistemática & $\begin{array}{l}\text { Identificação por } \\
\text { encomenda }\end{array}$ & $\operatorname{Sim}(\mathrm{MP})$ \\
\hline 5 & G. B. King & Descripção de Dactylopius magnolicida von Ihering. & Sistemática & Descrições novas & Não \\
\hline 5 & J. G. Foetterle, & Descripção de Lepidopteros novos do Brazil. & Sistemática & Descrições novas & Sim \\
\hline 5 & H. von Ihering & As Melanias do Brazil. & $\begin{array}{l}\text { Sistemática; } \\
\text { Biogeografia }\end{array}$ & Catálogo & Não \\
\hline 6 & H. W. Brölemann & Myriapodes du «Museu Paulista», II mémoire: Manáos. & Sistemática & $\begin{array}{l}\text { Identificação por } \\
\text { encomenda }\end{array}$ & $\operatorname{Sim}(\mathrm{MP})$ \\
\hline
\end{tabular}




\begin{tabular}{|c|c|c|c|c|c|}
\hline 6 & R. von Ihering & As vespas sociaes do Brazil. & $\begin{array}{l}\text { Sistemática; } \\
\text { Biologia }\end{array}$ & Catálogo & $\operatorname{Sim}(\mathrm{MP})$ \\
\hline 6 & H. von Ihering & As aves do Paraguay em comparação com as de S. Paulo. & $\begin{array}{l}\text { Sistemática; } \\
\text { Biogeografia }\end{array}$ & Catálogo & $\operatorname{Sim}(\mathrm{MP})$ \\
\hline 6 & H. von Ihering & O Rio Juruá. & Sistemática & Catálogo & $\operatorname{Sim}(\mathrm{MP})$ \\
\hline 6 & R. von Ihering & Biologia das abelhas solitarias do Brazil. & Biologia & - & Não \\
\hline 6 & $\begin{array}{l}\text { Pe. E. Wasmann } \\
\text { S. J. (Luxemburgo) }\end{array}$ & $\begin{array}{l}\text { Contribuição para o estudo dos hospedes de abelhas } \\
\text { brasileiras. }\end{array}$ & Sistemática & $\begin{array}{l}\text { Identificação por } \\
\text { encomenda }\end{array}$ & Sim \\
\hline 7 & R. von Ihering & Os Peixes da agua doce do Brazil. & $\begin{array}{l}\text { Sistemática; } \\
\text { Biogeografia }\end{array}$ & Catálogo & $\operatorname{Sim}(\mathrm{MP})$ \\
\hline 7 & H. von Ihering & $\begin{array}{l}\text { Historia da fauna marina do Brazil e das regiões visinhas da } \\
\text { America meridional ( traducção do Cap. XII da monographia } \\
\text { "Les Mollusques fossiles du Tertiaire et du Crétacé superieur de } \\
\text { l'Argentine"). }\end{array}$ & Biogeografia & - & Não \\
\hline 8 & A. Hempel & $\begin{array}{l}\text { Descripção de um novo genero e de uma nova especie de } \\
\text { Coccidas. }\end{array}$ & Sistemática & Descrições novas & Sim \\
\hline 8 & J. Weise & Aufzählung von Coccinellen aus dem Museu Paulista. & Sistemática & $\begin{array}{l}\text { Identificação por } \\
\text { encomenda }\end{array}$ & $\operatorname{Sim}(\mathrm{MP})$ \\
\hline 8 & J. Brethes & $\begin{array}{l}\text { Quelques nouveaux Céropalides (Hymenopt.) du Musée de } \\
\text { S. Paulo. }\end{array}$ & Sistemática & Descrições novas & $\operatorname{Sim}(\mathrm{MP})$ \\
\hline 8 & C. Schrottky & Descripção de abelhas novas do Brazil e de regiões visinhas. & Sistemática & Descrições novas & $\operatorname{Sim}(\mathrm{MP})$ \\
\hline 8 & R. von Ihering & Os Amphibios do Brazil. 1a Ordem: Gymnophiona. & Biogeografia & - & Não \\
\hline
\end{tabular}




\begin{tabular}{|c|c|c|c|c|c|}
\hline 8 & H. von Ihering & Os mammiferos do Brazil Meridional: I Contribuição: Carnivora. & Sistemática & Catálogo & $\operatorname{Sim}(\mathrm{MP})$ \\
\hline 8 & R. von Ihering & As Cobras do Brazil. & $\begin{array}{l}\text { Sistemática; } \\
\text { Estudo aplicado }\end{array}$ & Catálogo & $\operatorname{Sim}(\mathrm{MP})$ \\
\hline 8 & R. von Ihering & Algumas especies novas de peixes d'agua doce. & Sistemática & Descrições novas & $\operatorname{Sim}(\mathrm{MP})$ \\
\hline 8 & G. Luderwaldt & Quatro Lamellicorneos termitophilos. & $\begin{array}{l}\text { Biogeografia; } \\
\text { Biologia }\end{array}$ & - & $\operatorname{Sim}(\mathrm{MP})$ \\
\hline 8 & G. Luderwaldt & Os insectos necrophagos paulistas. & Sistemática & Outro & $\operatorname{Sim}(\mathrm{MP})$ \\
\hline 8 & H. von Ihering & Origem da fauna neotropica. & Biogeografia & - & Não \\
\hline 8 & R. von Ihering & Cobras e Amphibios das ilhotas de «Aguapé». & Sistemática & $\begin{array}{l}\text { Identificação por } \\
\text { encomenda }\end{array}$ & $\operatorname{Sim}(\mathrm{MP})$ \\
\hline 8 & R. von Ihering & Algumas especies novas de Vespas solitárias. & Sistemática & Descrições novas & $\operatorname{Sim}(\mathrm{MP})$ \\
\hline 8 & $\begin{array}{l}\text { Padre Longinos } \\
\text { Navas S. J. }\end{array}$ & Neuropteros del Brazil. & Sistemática & $\begin{array}{l}\text { Identificação por } \\
\text { encomenda }\end{array}$ & Sim \\
\hline 9 & R. von Ihering & $\begin{array}{l}\text { Tres Chalcididas parasitas do «bicho do café» (Leucoptera } \\
\text { coffeella) (Tineid.). }\end{array}$ & Sistemática & Descrições novas & $\operatorname{Sim}(\mathrm{MP})$ \\
\hline 9 & A. Ducke. & O genero Pterombrus Sm. (Hymen.). & Sistemática & Descrições novas & Sim \\
\hline 9 & R. von Ihering & $\begin{array}{l}\text { As traças que vivem sobre a «preguiça», Bradypophila garbei } \\
\text { n. gen., n. sp. (Lepid. fam. Pyralid.). }\end{array}$ & Sistemática & Descrições novas & $\operatorname{Sim}(\mathrm{MP})$ \\
\hline 9 & F. Iglesias & Ipidae brasileiros: Diagnose de duas espécies novas. & Sistemática & Descrições novas & Sim \\
\hline 9 & C. Schrottky & $\begin{array}{l}\text { As espécies brazileiras do gen. Megachile (Hymenopt.), como } \\
\text { supplemento ao «Ensaio das Abelhas solitarias do Brazil ». }\end{array}$ & Sistemática & Complemento & $\operatorname{Sim}(\mathrm{MP})$ \\
\hline
\end{tabular}




\begin{tabular}{|c|c|c|c|c|c|}
\hline 9 & R. von Ihering & $\begin{array}{l}\text { Diagnose de urna Eucoela, (Hymenop. Cynip.) parasita das } \\
\text { «Moscas das fructas». }\end{array}$ & Sistemática & Descrições novas & $\operatorname{Sim}(\mathrm{MP})$ \\
\hline 9 & R. von Ihering & O genero Parachartergus R. v. Ih. (Vespas sociaes). & Sistemática & $\begin{array}{l}\text { Revisão } \\
\text { taxonômica }\end{array}$ & Não \\
\hline 9 & A. Ducke & Emendas ao Catalogo das Chrysididas do Brazil. & Sistemática & $\begin{array}{l}\text { Revisão } \\
\text { taxonômica }\end{array}$ & Não \\
\hline 9 & H. von Ihering & Os bugios do genero Alouatta. & Sistemática & $\begin{array}{l}\text { Revisão } \\
\text { taxonômica }\end{array}$ & $\operatorname{Sim}(\mathrm{MP})$ \\
\hline 9 & R. von Ihering & $\begin{array}{l}\text { As espécies brazileiras de Nilionidas (Coleopt.) e a posição } \\
\text { systematica da família, pelo estudo das larvas. }\end{array}$ & Sistemática & $\begin{array}{l}\text { Revisão } \\
\text { taxonômica }\end{array}$ & $\operatorname{Sim}(\mathrm{MP})$ \\
\hline 9 & R. von Ihering & Duas especies novas de Peixes da fam. Cichlidae. & Sistemática & Descrições novas & $\operatorname{Sim}(\mathrm{MP})$ \\
\hline 9 & H. von Ihering & Os Gambás do Brazil, Marsupiaes do gen. Didelphis. & Sistemática & $\begin{array}{l}\text { Revisão } \\
\text { taxonômica }\end{array}$ & $\operatorname{Sim}(\mathrm{MP})$ \\
\hline 9 & Fr. Iglesias & Insectos contra insectos: as Coccinellidas. & Estudo aplicado & - & Não \\
\hline 9 & R. von Ihering & $\begin{array}{l}\text { Notas entomologicas (Nilio n. sp. e um } 8^{\circ} \text { parasita de } \\
\text { Leucoptera). }\end{array}$ & Sistemática & Descrições novas & $\operatorname{Sim}(\mathrm{MP})$ \\
\hline 9 & H. Luederwaldt & Biologia de varias especies de Pinotus (Coleop.) de S. Paulo. & $\begin{array}{l}\text { Biologia; Estudo } \\
\text { aplicado }\end{array}$ & - & Não \\
\hline 9 & H. von Ihering & Biologia e classificação das Cuculidas brazileiras. & $\begin{array}{l}\text { Sistemática; } \\
\text { Biogeografia }\end{array}$ & $\begin{array}{l}\text { Revisão } \\
\text { taxonômica }\end{array}$ & Não \\
\hline 9 & H. von Ihering & Novas contribuições para a Ornithologia do Brazil. & Biologia & - & $\operatorname{Sim}(\mathrm{MP})$ \\
\hline
\end{tabular}




\section{Iconografia}

\section{Figura 1}

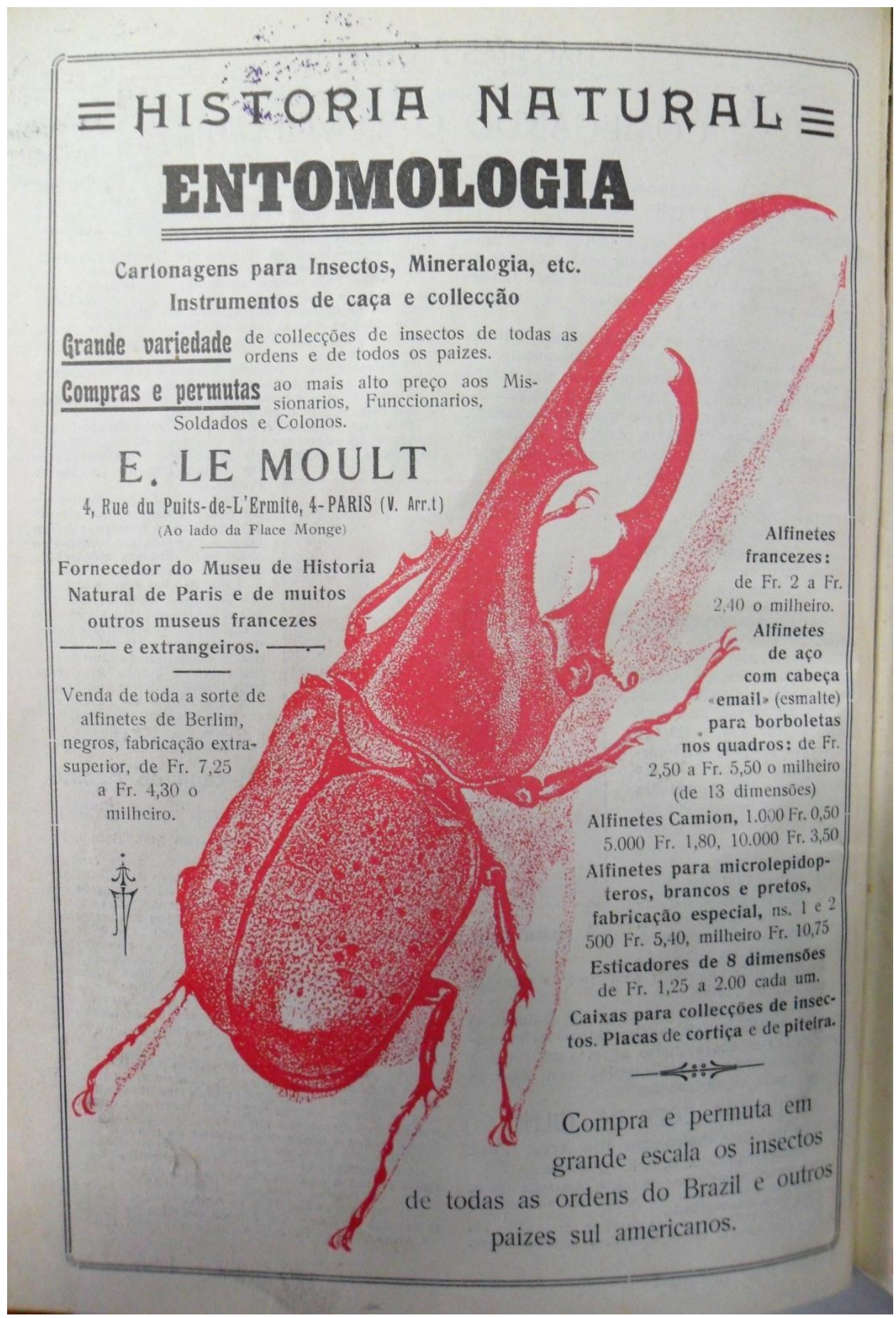

Anúncio da casa comercial E. Le Moult, sediada em Paris.

Publicado em: Chacaras e Quintaes, 2, 1, jul. 1910, contracapa. 
Figura 2

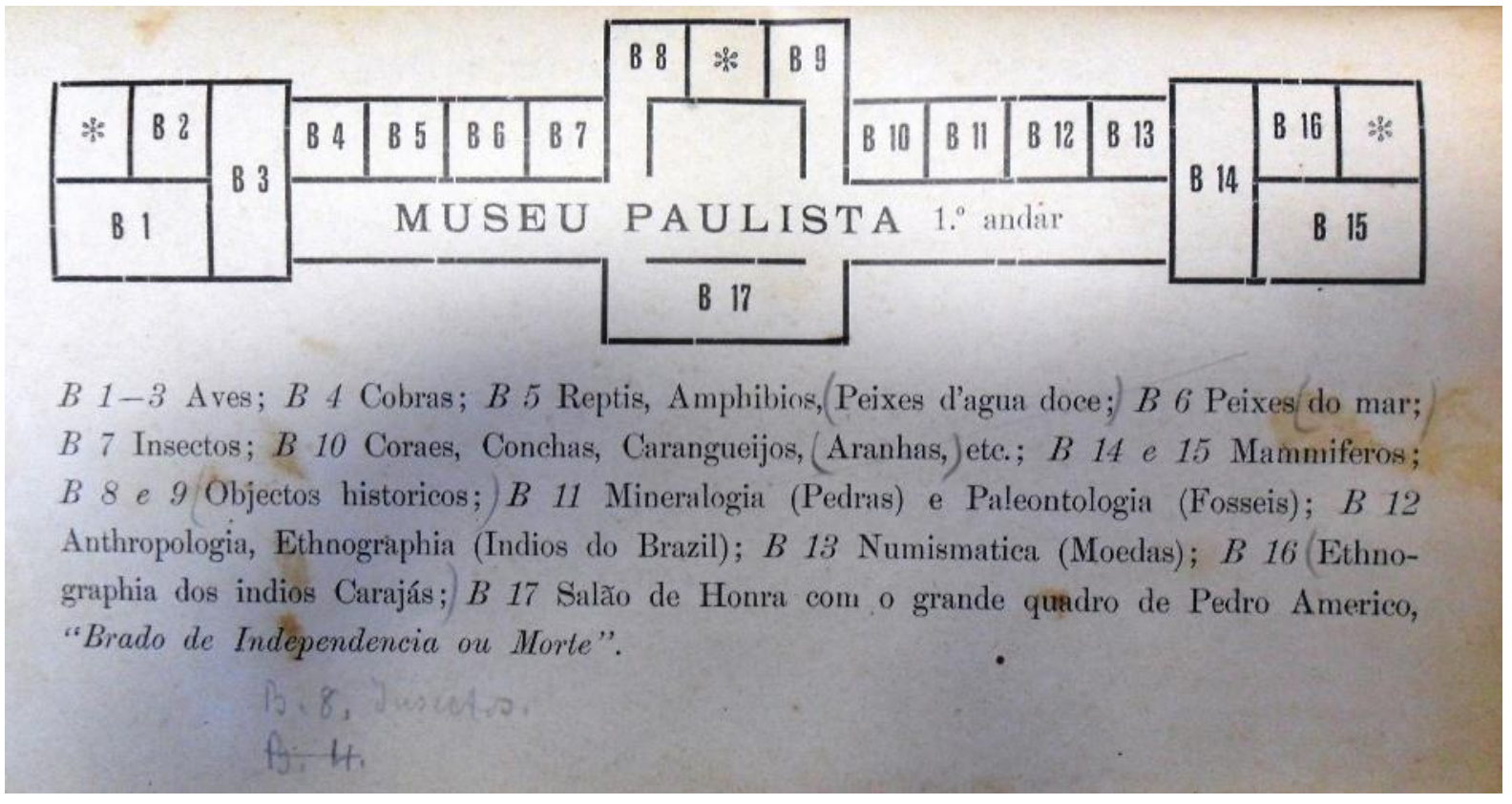

Planta do Museu Paulista com respectivas legendas.

Publicado em: IHERING, Rodolpho von. Guia pelas collecções do Museu Paulista. São Paulo: Cardozo, Filho \& Cia, 1907, p. 79. 
Figura 3

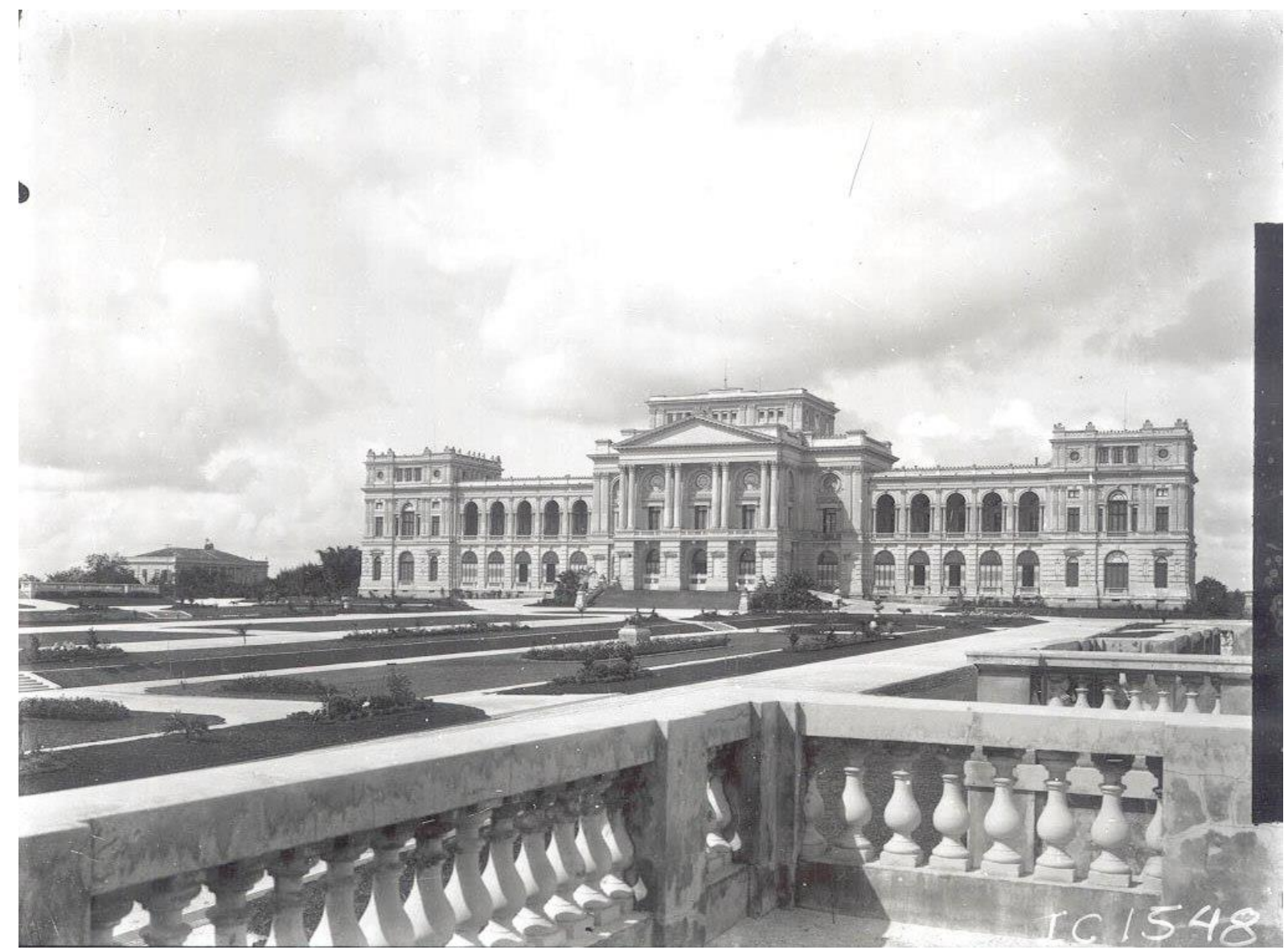

Fotografia da fachada do Museu Paulista, início do século XX.

Arquivo Permanente do Museu Paulista/Fundo Museu Paulista (APMP/FMP). 
Figura 4

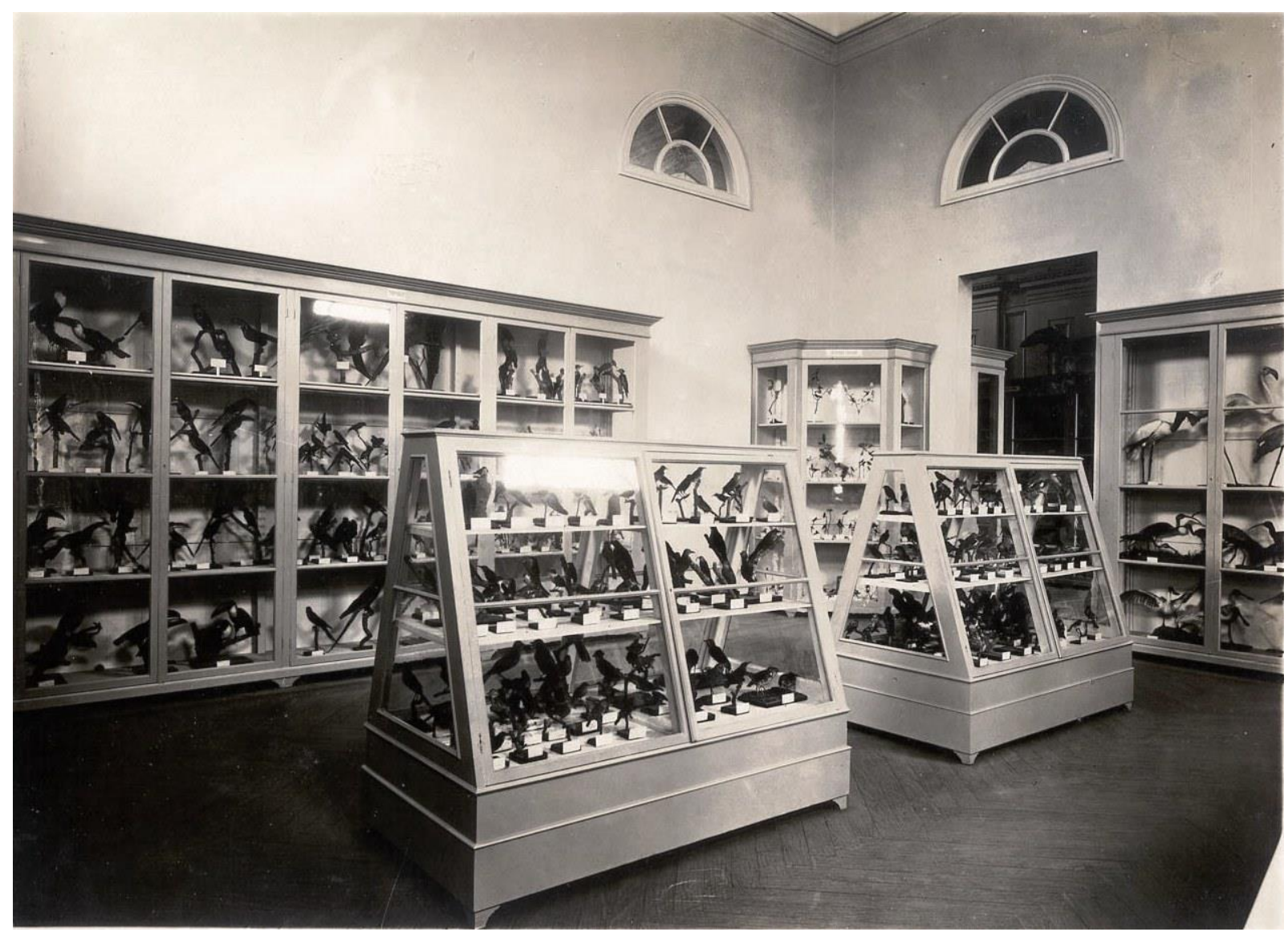

Fotografia da Sala B1 - Aves

APMP/FMP ${ }^{373}$

${ }^{373}$ As fotografias de exposições do Museu Paulista provenientes do APMP/FMP aqui reproduzidas não apresentam data de produção, a não ser por dois casos: as figuras de número 6 e 9 seriam, segundo informações constantes no banco de dados iconográfico do Museu Paulista, de 1938. É provável que, além dessas duas, outras tenham sido produzidas em período posterior ao fim da gestão Ihering. Maurício Silva apontou, em sua dissertação, períodos de produção prováveis para algumas das fotografias de exposições presentes no APMP/FMP. Segundo informação pessoal do autor, as datas foram inferidas a partir do cotejo do conteúdo exposto com informações existentes nos relatórios da diretoria do Museu Paulista. Ver SILVA, Maurício Cândido da, op. cit., 2006. Aqui, preferimos não inferir datas, mas, comparando-se as fotografias com as descrições de salas de exposição contidas no Guia pelas collecções do Museu Paulista, observa-se que as imagens correspondem, em grande parte, ao que está descrito no Guia. 
Figura 5

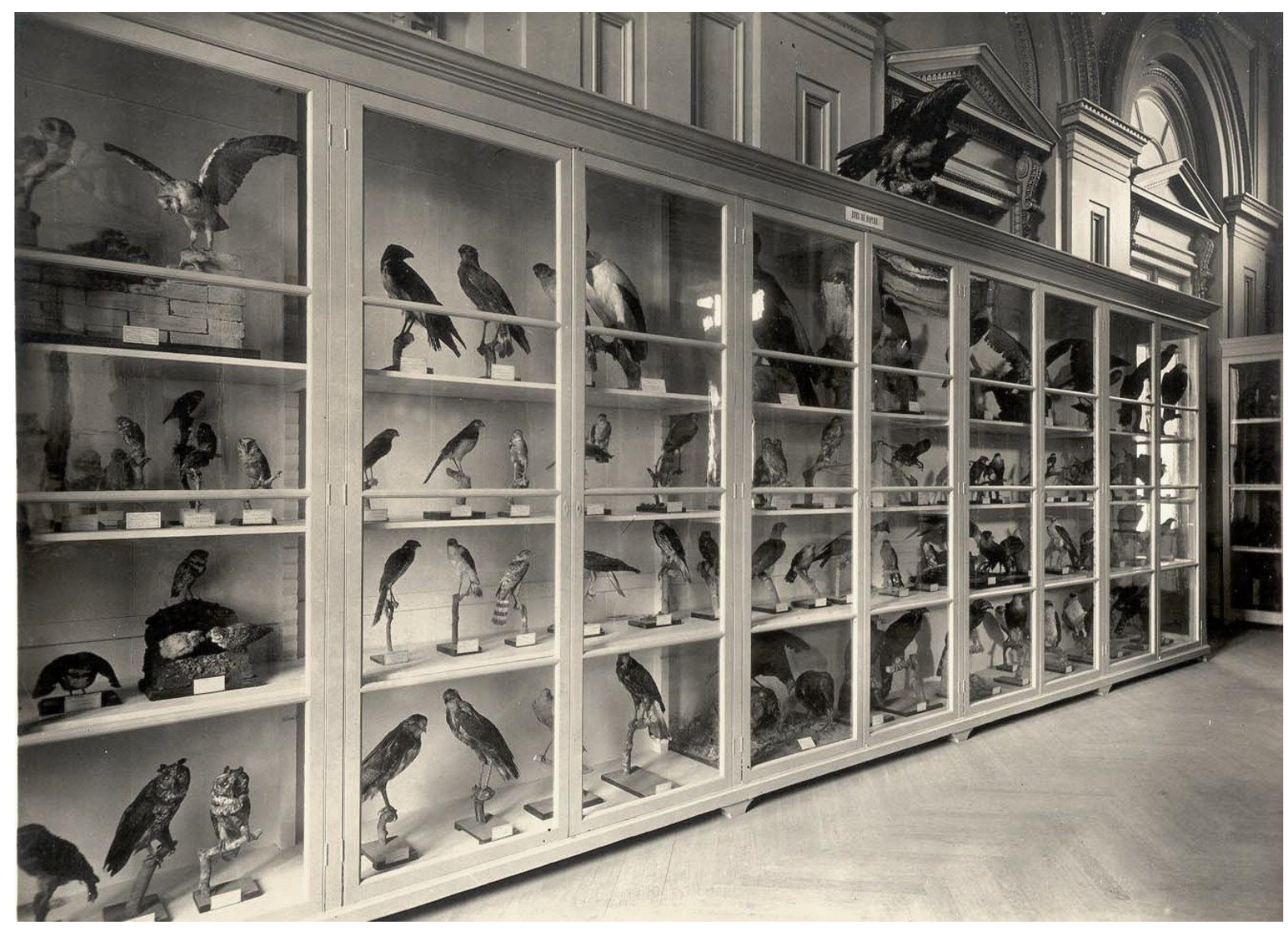

Fotografia da Sala B3 - Aves

APMP/FMP 
Figura 6

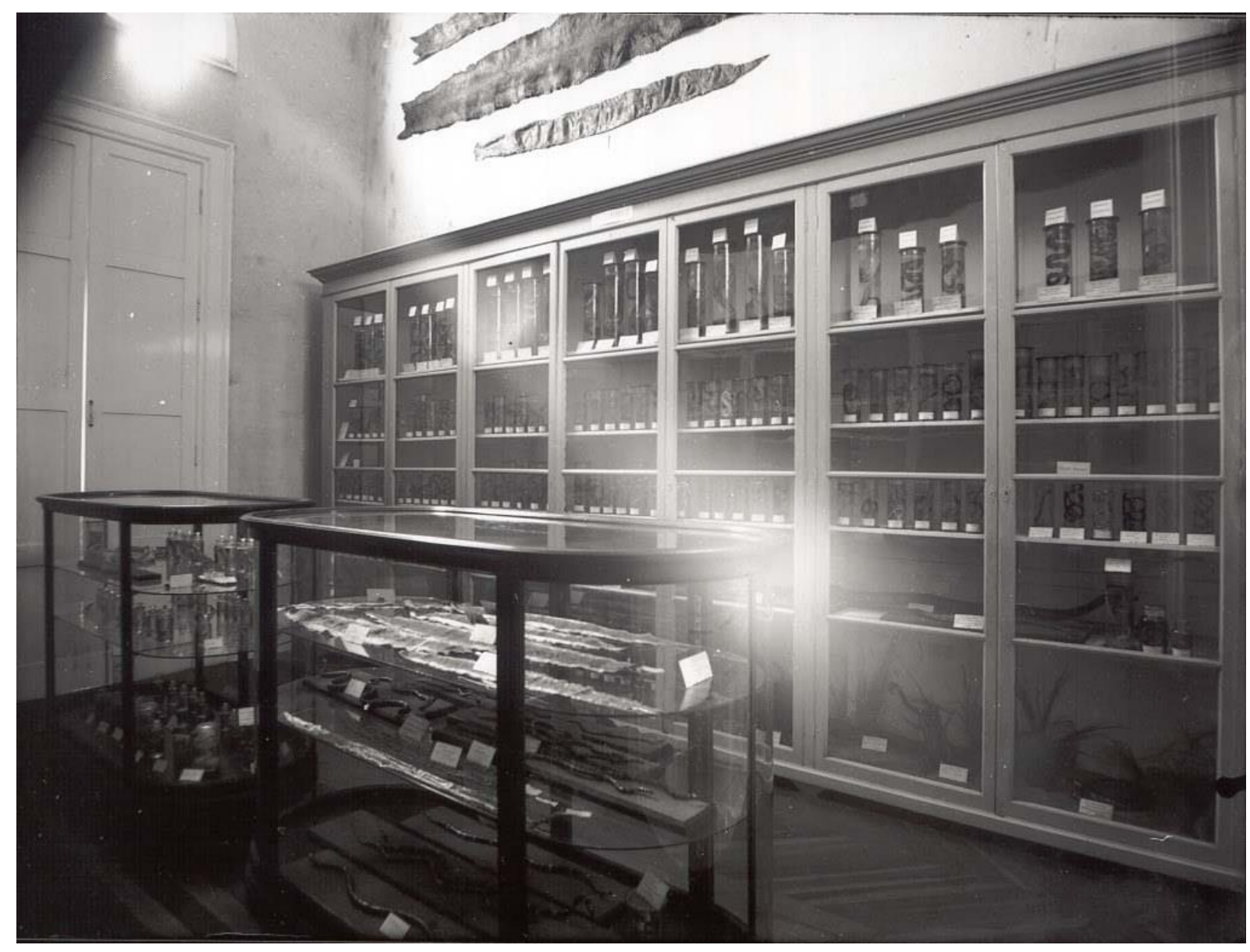

Fotografia da Sala B4 - Cobras

APMP/FMP 
Figura 7

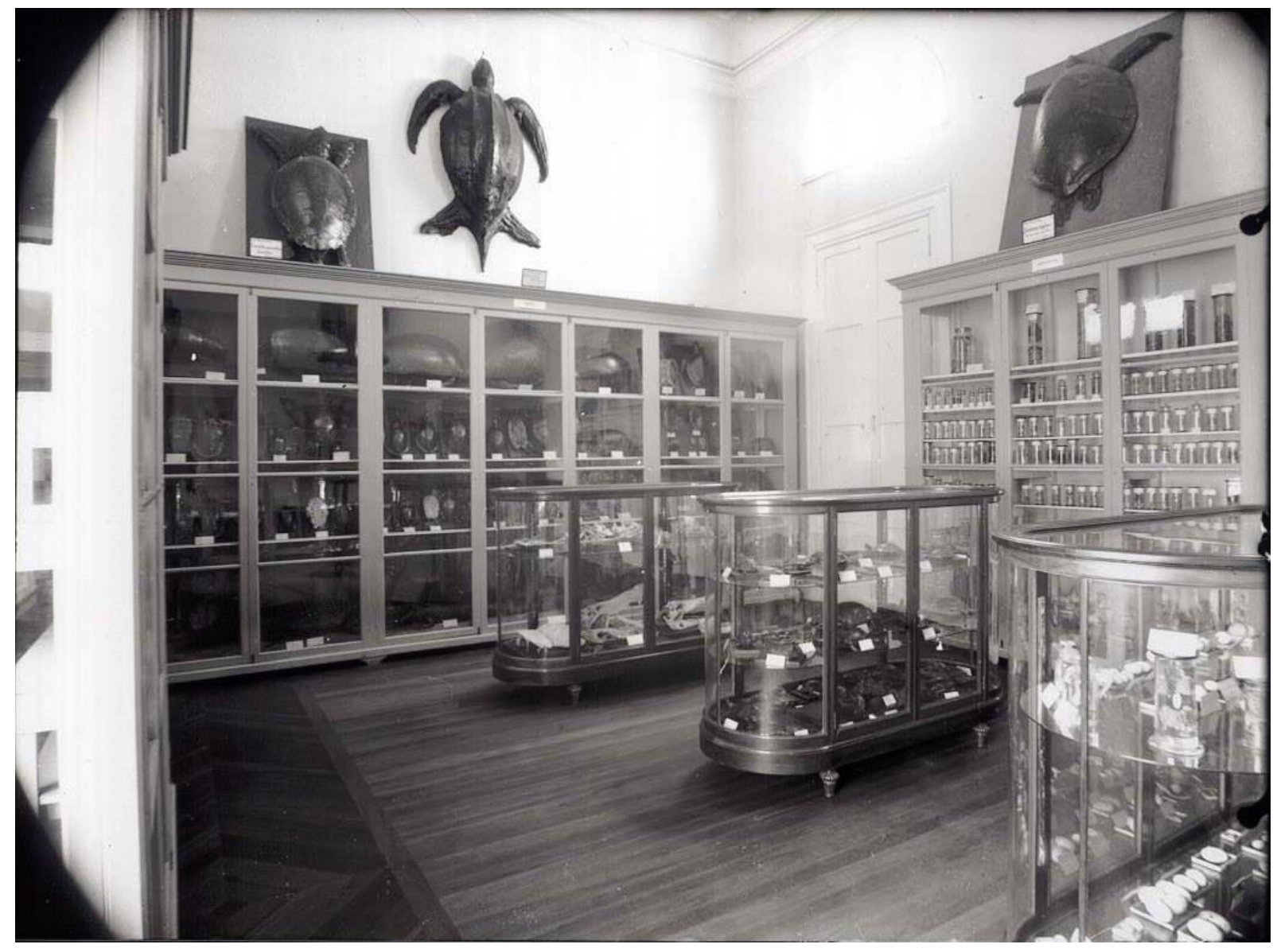

Fotografia da Sala B5 - Répteis, anfíbios e peixes de água doce APMP/FMP 
Figura 8

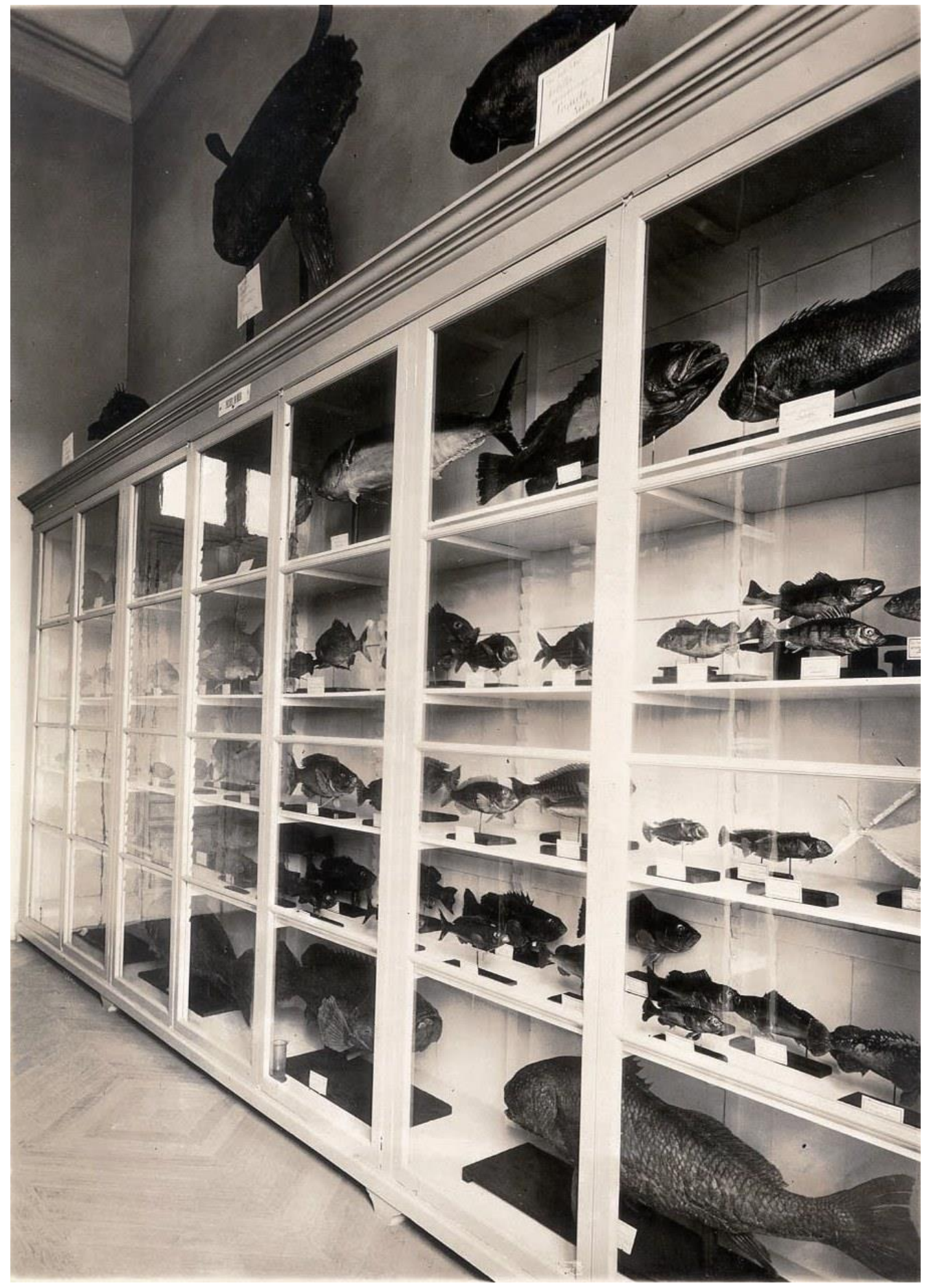

Fotografia da Sala B5 - Répteis, anfíbios e peixes de água doce APMP/FMP 
Figura 9

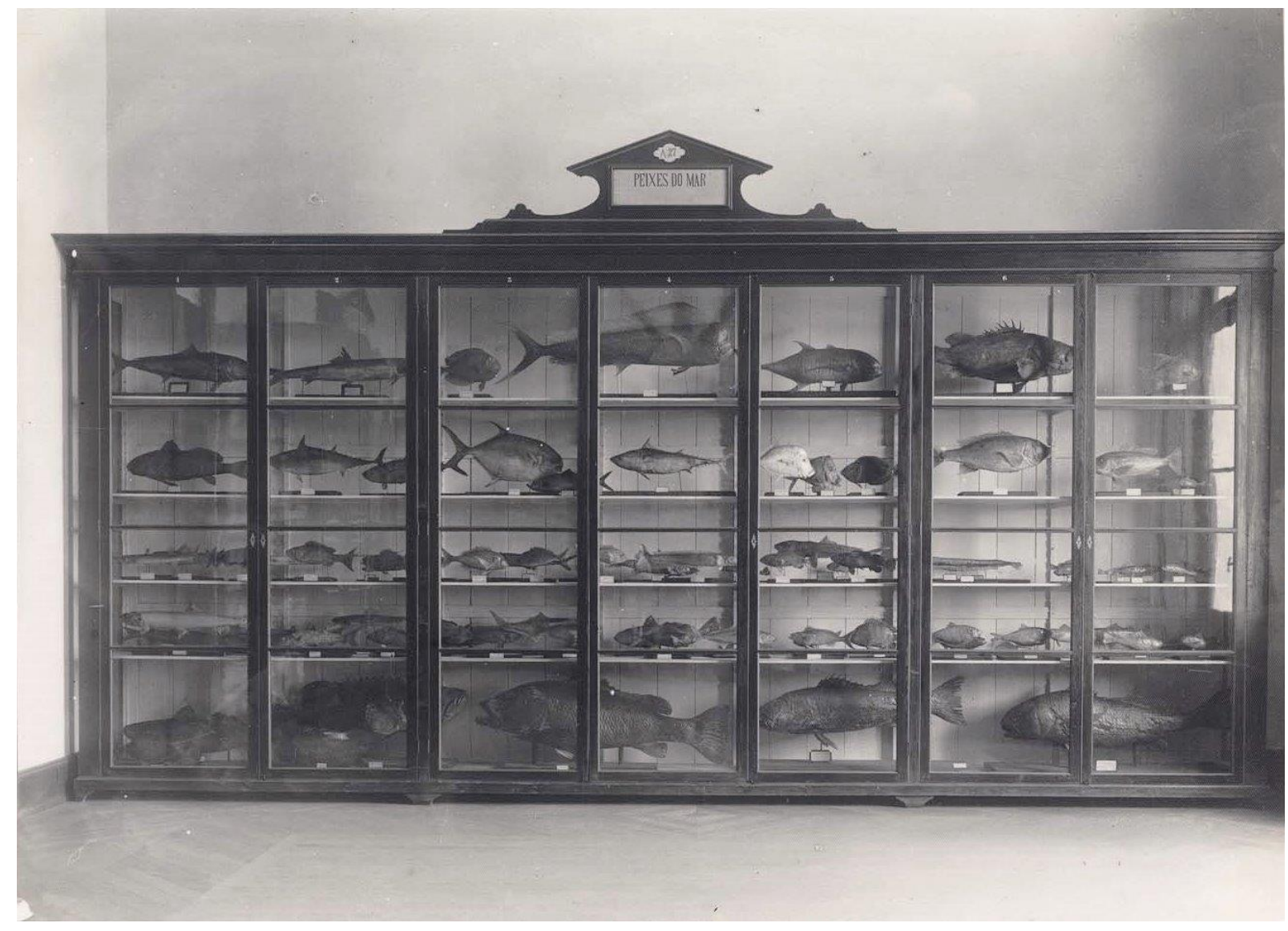

Fotografia da Sala B6 - Peixes do mar

APMP/FMP 
Figura 10

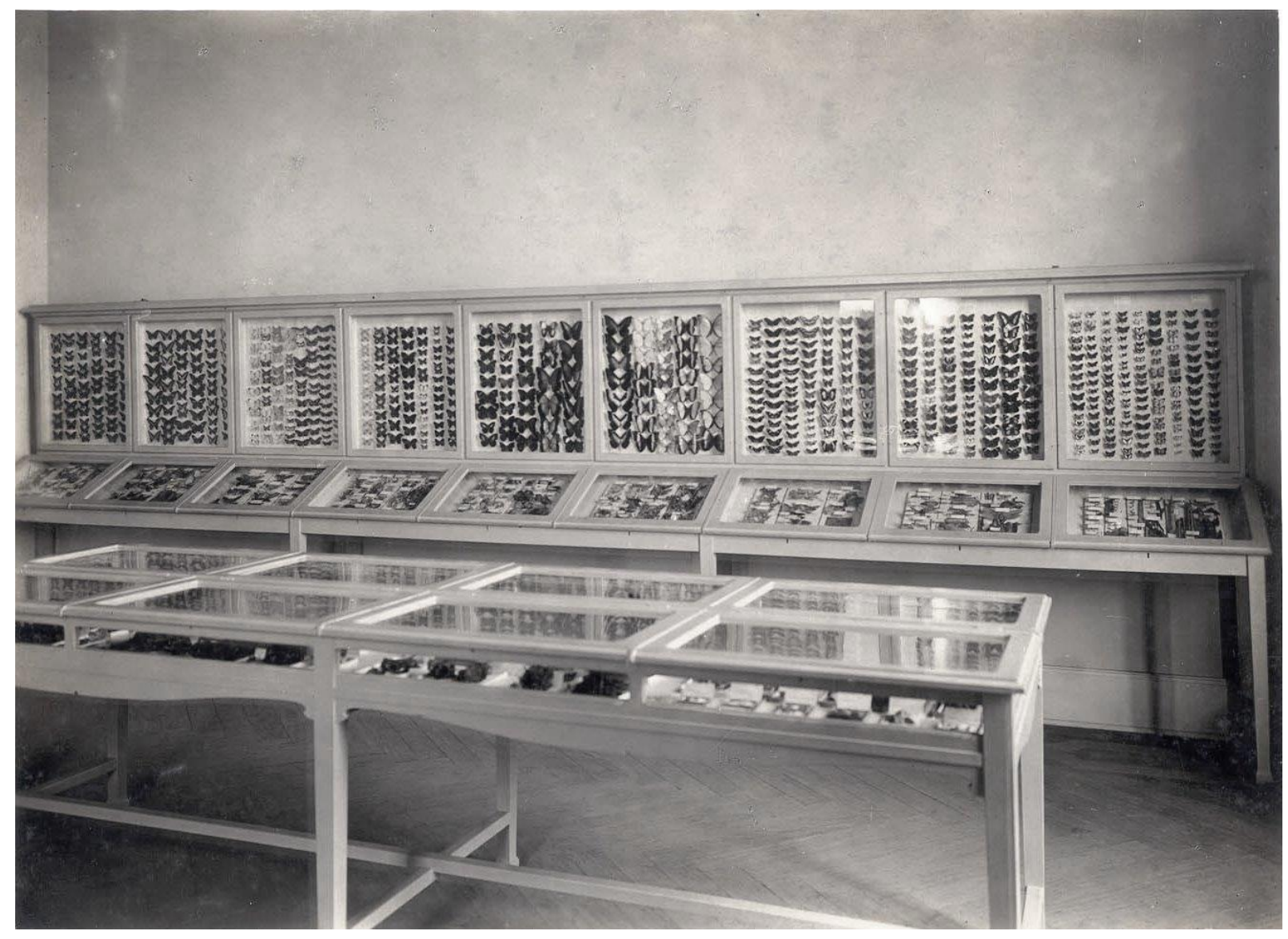

Fotografia da Sala B7 - Insetos

APMP/FMP 
Figura 11

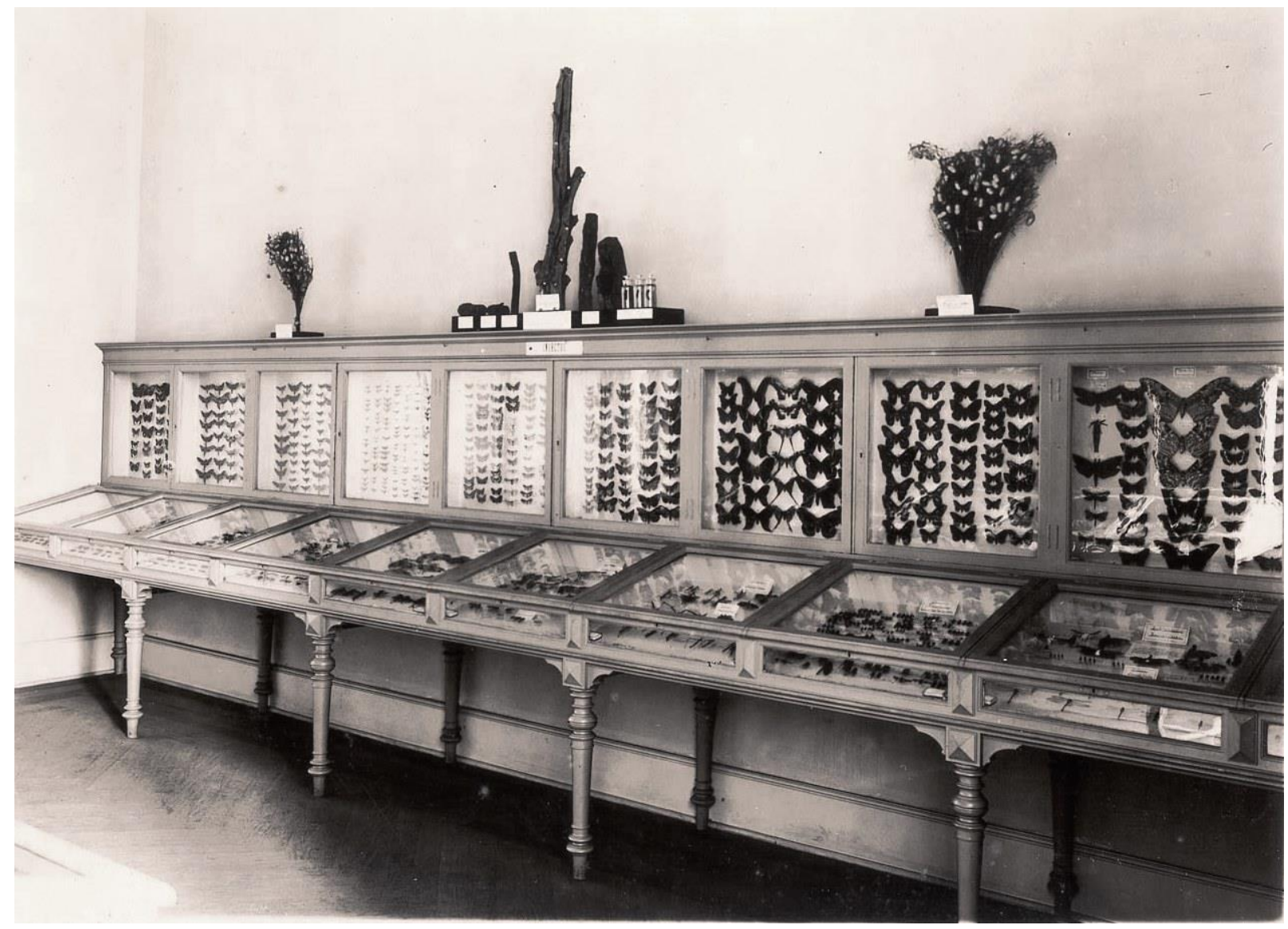

Fotografia da Sala B7 - Insetos

APMP/FMP 
Figura 12

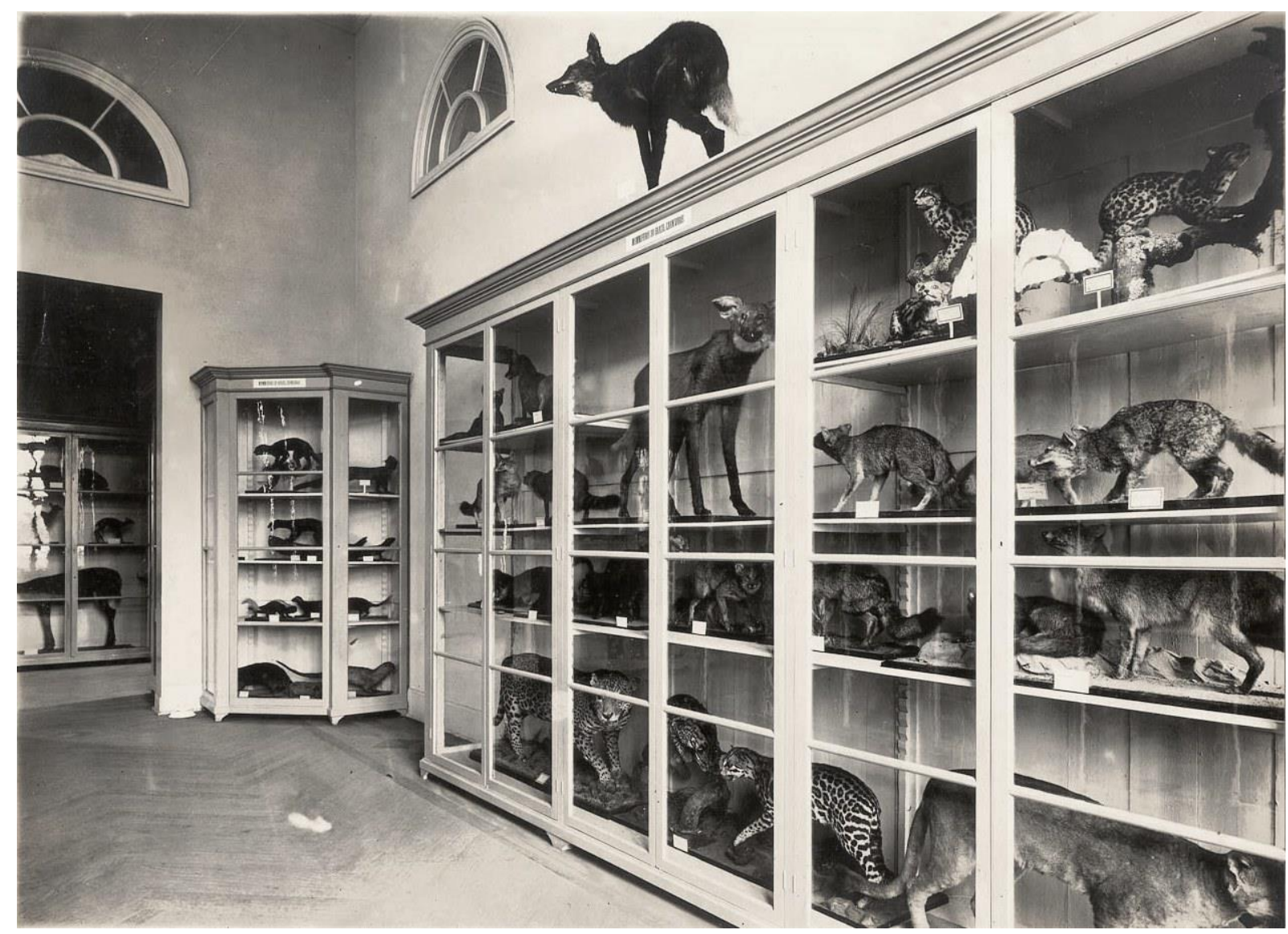

Fotografia da Sala B15 - Mamíferos

APMP/FMP 
Figura 13

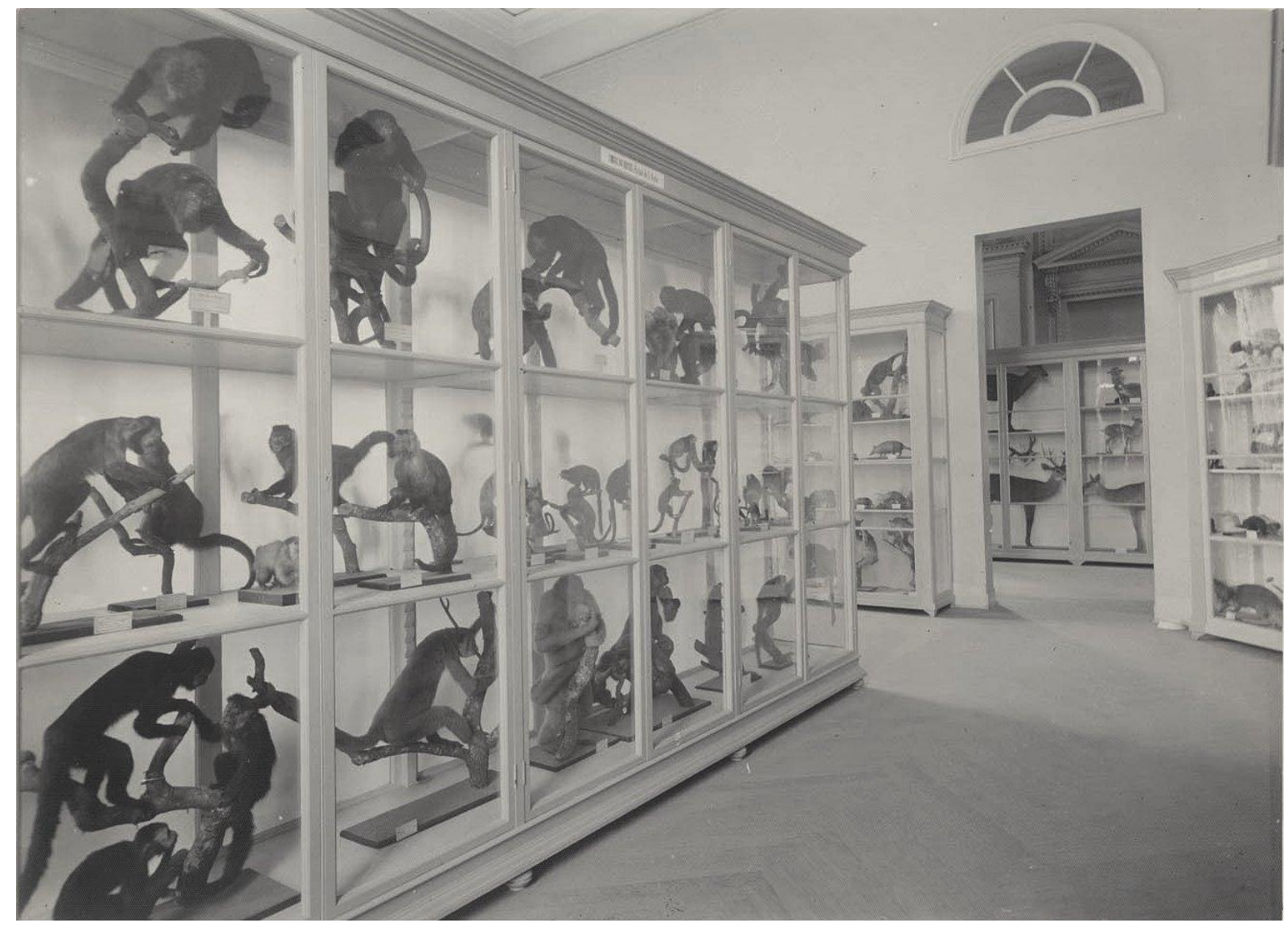

Fotografia da Sala B15 - Mamíferos

APMP/FMP 
Figura 14

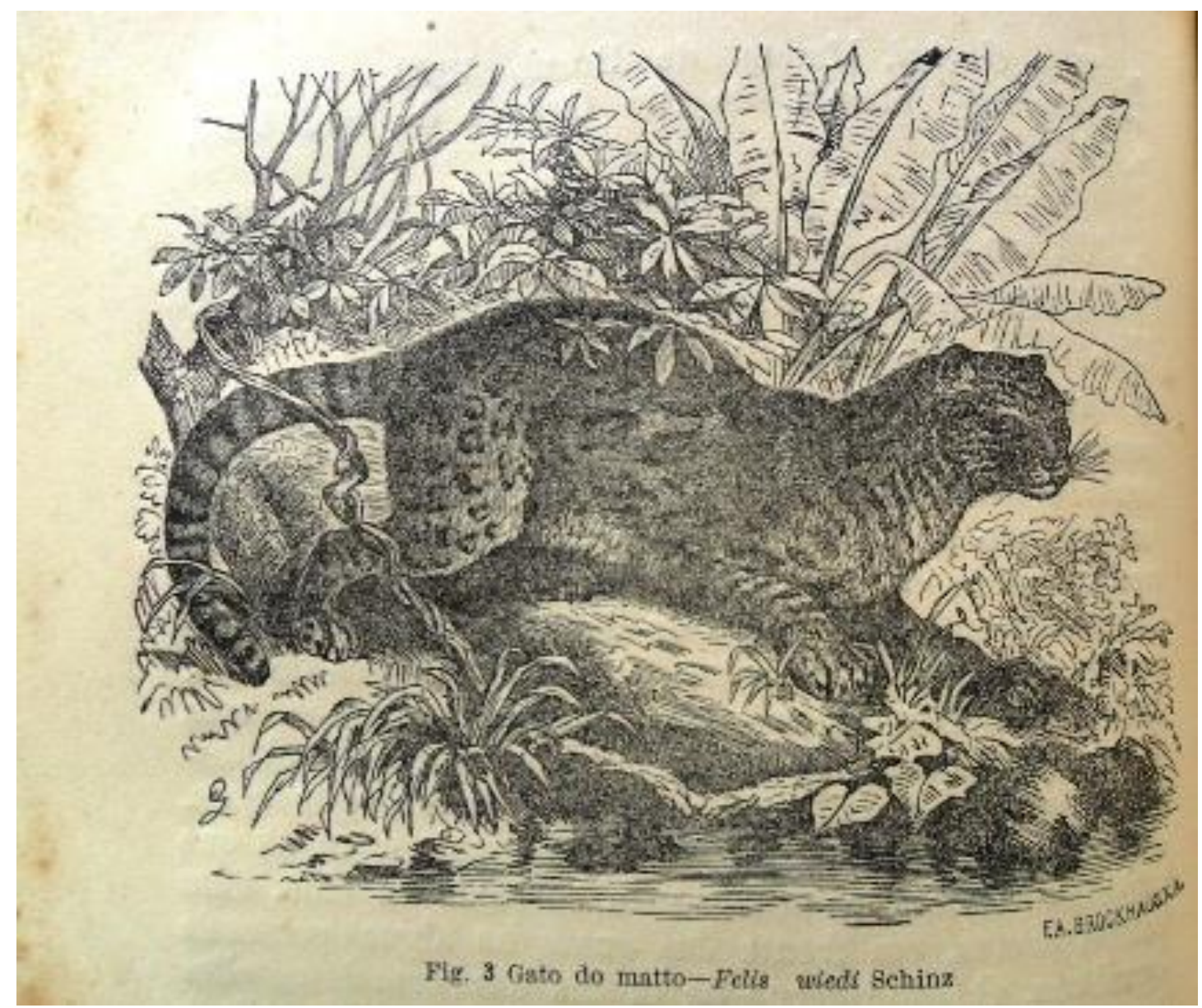

Gravura de gato do mato, assinada por "G.". Clichê proveniente da editora alemã F. A. Brockhaus.

Publicado em: IHERING, Hermann von. Os mammiferos do Brazil Meridional: I Contribuição: Carnivora. Revista do Museu Paulista, 8, 1911, p. 184. 
Figura 15

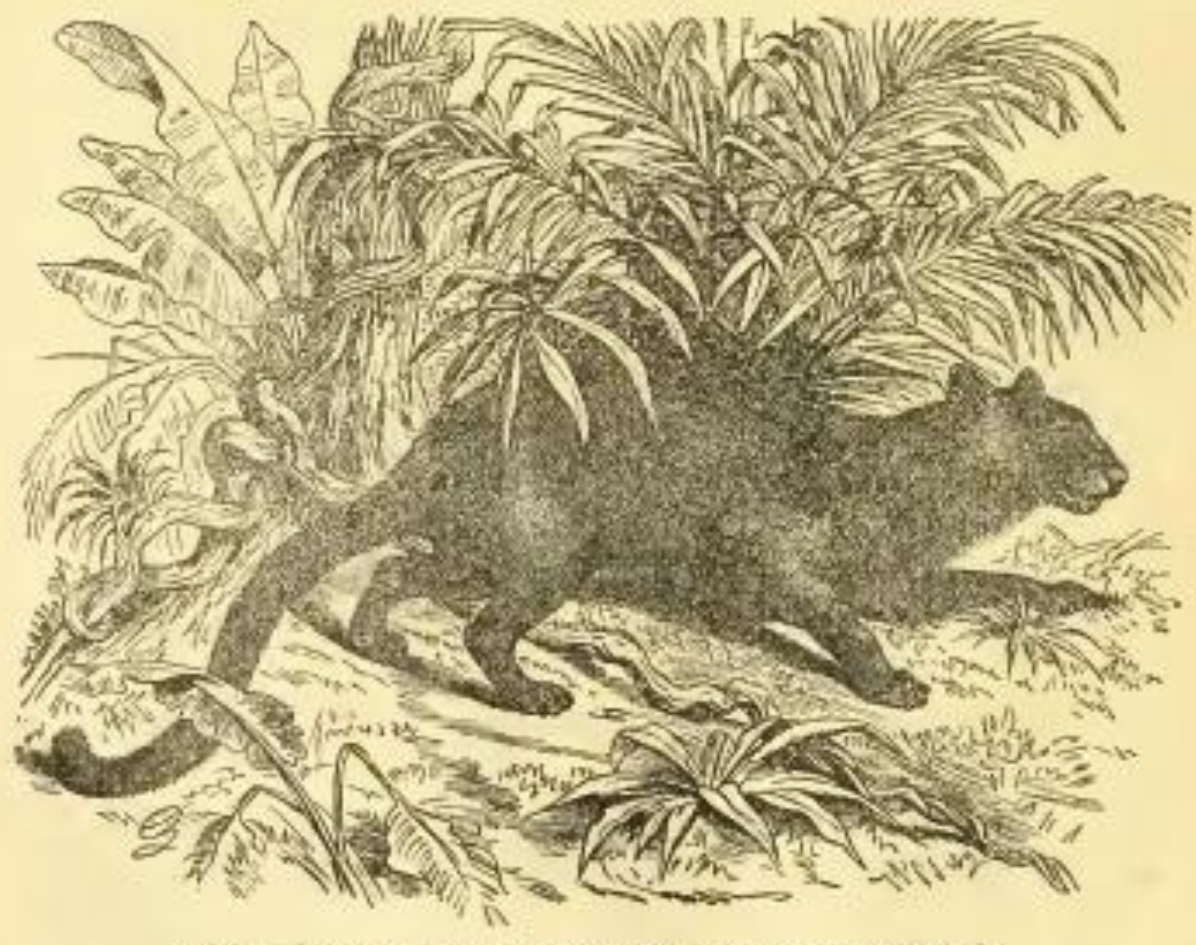

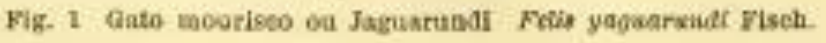

Gravura de gato mourisco, assinada por "G.". Clichê proveniente da editora alemã F. A. Brockhaus.

Publicado em: IHERING, Hermann von. Os mammiferos do Brazil Meridional: I Contribuição: Carnivora. Revista do Museu Paulista, 8, 1911, p. 164. 


$$
-171-
$$

manchas arredondadas pretas, que se prolongam pelo dorso, no meio do qual se tornam estreitas e alongadas. Nos lados notan-se cinco fileiras de grandes anneis pretos, que no centro incluem muitas vezes uma outra nanchinha preta. No meio destes anneis, que em geral sâo completamente fechados, a côr ruiva è mais carregada do que no campo. Tambem no lado inferior nota-se grandes manchas pretas e do mesmo modo na cauda, em cuja parte terminal formam anneis mais ou menos completos; a ponta da cauda é toda preta. No lado interior as orelhas stio cobertas de cabellos brancos e no lado exterior sato escuras, com uma grande mancha central branca ou amarellada. A cara é salpicada e os beicos são bordados de preto.

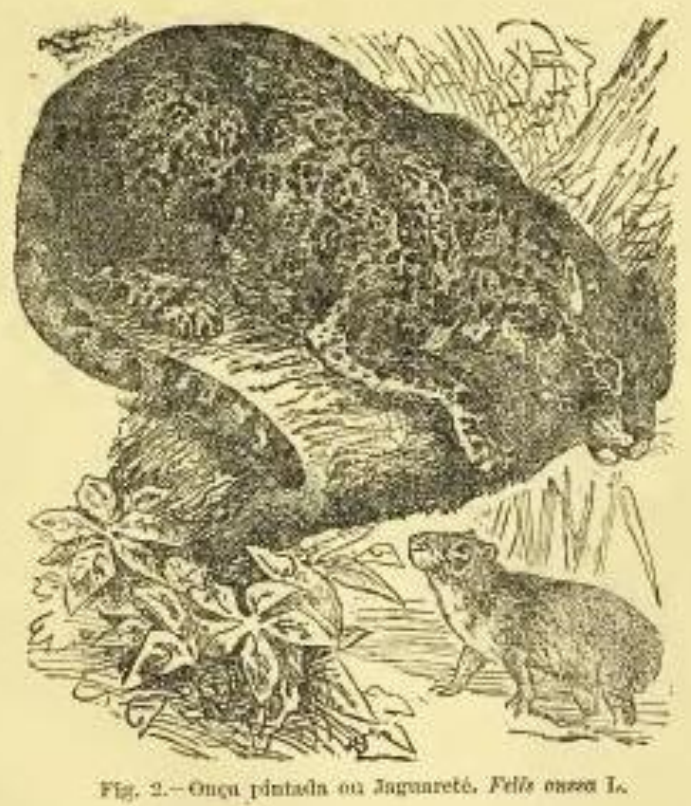

Entre os dous sexos não ha diflerença notavel quanto ao colorido; os filhotes são cobertos de pello macio e comprido, cuja côr é mais clara e as manchas sð̃o menos numerosas e mais irregulares na sua distribuiçāo.

Gravura de onça pintada, assinada por "G.". Clichê proveniente da editora alemã F. A. Brockhaus.

Publicado em: IHERING, Hermann von. Os mammiferos do Brazil Meridional: I Contribuição: Carnivora. Revista do Museu Paulista, 8, 1911, p. 171. 


\section{Figura 17}

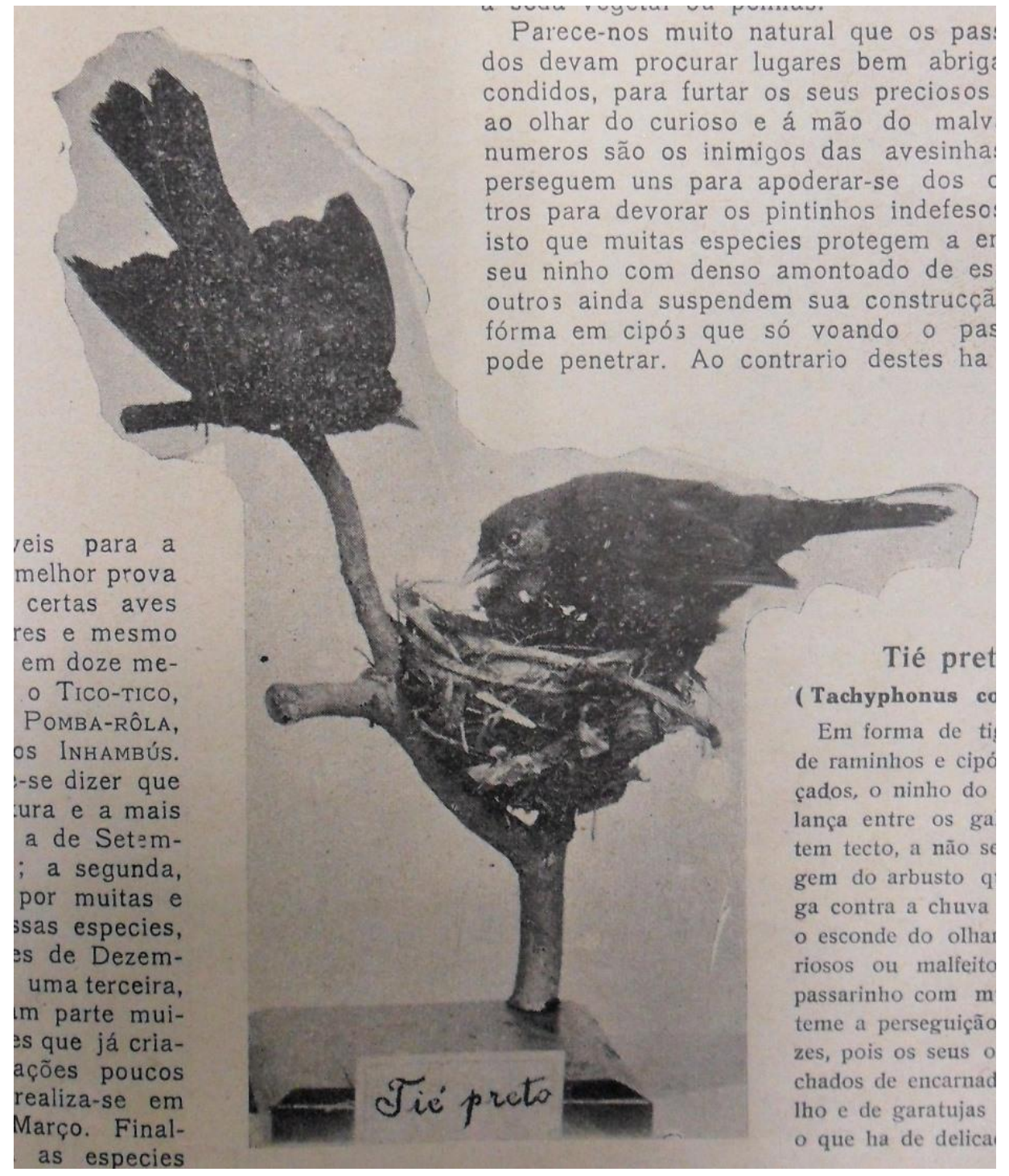

Fotografia de pássaros empalhados

Publicado em: IHERING, Rodolpho von. A Festa das Aves. Chacaras

e Quintaes, 3, 3, mar. 1911, p. 19. 
Figura 18

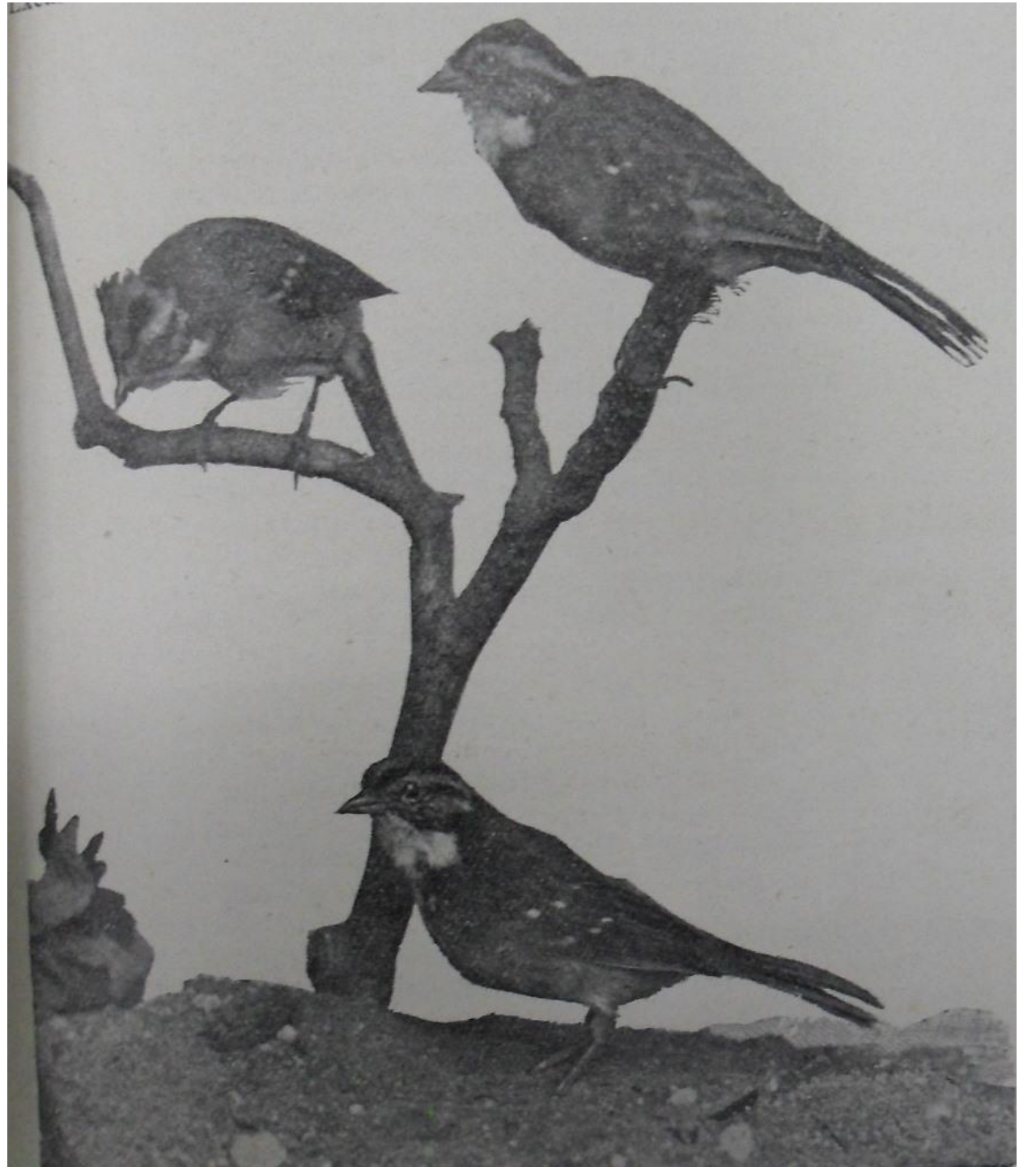

Fotografia de pássaros empalhados

Publicado em: IHERING, Rodolpho von. Em defesa do tico-tico.

Chacaras e Quintaes, 8, 4, out. 1913, p. 47. 
Figura 19

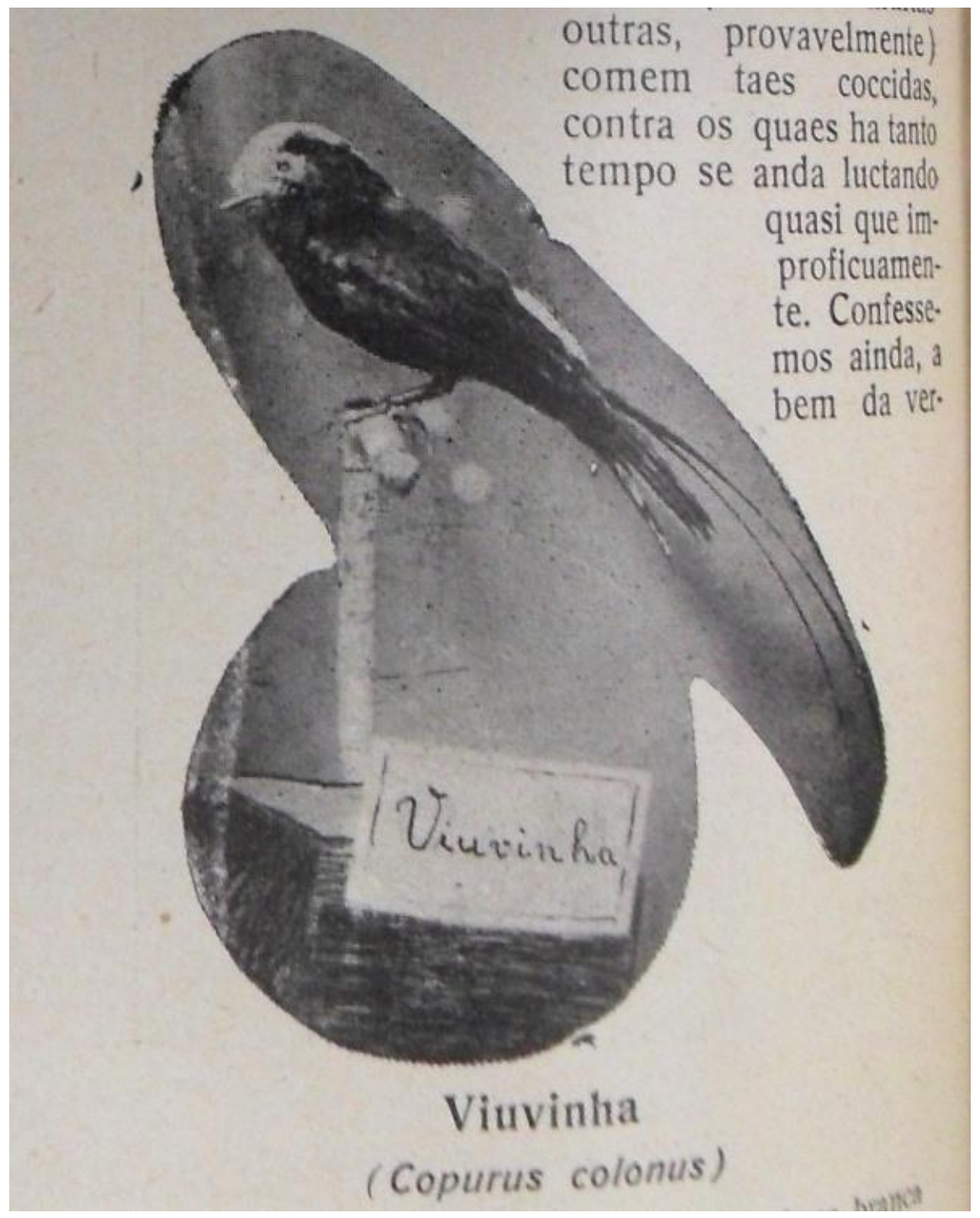

Fotografia de pássaro empalhado

Publicado em: IHERING, Rodolpho von. Protegei os passarinhos! Chacaras e Quintaes, 3, 2, fev. 1911, p. 46. 